\title{
The role of coagulation factor XII in fibrin clot formation and fibrinolysis
}

Citation for published version (APA):

Konings, J. (2014). The role of coagulation factor XII in fibrin clot formation and fibrinolysis. [Doctoral Thesis, Maastricht University]. Maastricht University. https://doi.org/10.26481/dis.20140124jk

Document status and date:

Published: 01/01/2014

DOI:

10.26481/dis.20140124jk

Document Version:

Publisher's PDF, also known as Version of record

\section{Please check the document version of this publication:}

- A submitted manuscript is the version of the article upon submission and before peer-review. There can be important differences between the submitted version and the official published version of record.

People interested in the research are advised to contact the author for the final version of the publication, or visit the DOI to the publisher's website.

- The final author version and the galley proof are versions of the publication after peer review.

- The final published version features the final layout of the paper including the volume, issue and page numbers.

Link to publication

\footnotetext{
General rights rights.

- You may freely distribute the URL identifying the publication in the public portal. please follow below link for the End User Agreement:

www.umlib.nl/taverne-license

Take down policy

If you believe that this document breaches copyright please contact us at:

repository@maastrichtuniversity.nl

providing details and we will investigate your claim.
}

Copyright and moral rights for the publications made accessible in the public portal are retained by the authors and/or other copyright owners and it is a condition of accessing publications that users recognise and abide by the legal requirements associated with these

- Users may download and print one copy of any publication from the public portal for the purpose of private study or research.

- You may not further distribute the material or use it for any profit-making activity or commercial gain

If the publication is distributed under the terms of Article $25 \mathrm{fa}$ of the Dutch Copyright Act, indicated by the "Taverne" license above, 


\section{The role of coagulation factor XII in fibrin clot formation and fibrinolysis}


(c) J. Konings, Maastricht 2013

Thesis Maastricht University

ISBN 978-90-9027860-5

Printed by: Drukkerij de Econoom, Beek

Cover design by: Peter op den Kamp and Sandra Daems

All rights reserved. No part of this thesis may be reproduced, stored in a retrieval system or transmitted in any form or by any means, without the permission in writing from the author, or, when appropriate, of the publishers of the publications. 


\section{The role of coagulation factor XII in fibrin clot formation and fibrinolysis}

\section{PROEFSCHRIFT}

ter verkrijging van de graad van doctor aan de Universiteit Maastricht, op gezag van de Rector Magnificus, Prof. dr. L.L.G. Soete,

volgens het besluit van het College van Decanen,

in het openbaar te verdedigen

op vrijdag 24 januari 2014 om 12.00 uur

door

Joke Konings

Geboren op 14 april 1985 te Nieuwegein 


\section{Promotor:}

Prof. dr. H. ten Cate

\section{Co-promotor:}

Dr. J.W.P. Govers-Riemslag

\section{Beoordelingscommissie:}

Prof. dr. C.D. Stehouwer (voorzitter)

Prof. dr. T.M. Hackeng

Prof. dr. M. Levi (Academisch Medisch Centrum, Amsterdam)

Dr. M.P. de Maat (Erasmus Medisch Centrum, Rotterdam)

Prof. dr. R.J. van Oostenbrugge

The research described in this thesis was supported by a grant of the Dutch Heart Foundation (DHF-2008B120).

The research described in this thesis was supported by an unrestricted grant of Synapse BV.

Financial support by the Dutch Heart Foundation for the publication of this thesis is gratefully acknowledged. 
Voor papa 



\section{Table of contents}

Chapter 1 General introduction and outline of the thesis 9

Chapter 2 Factor XIla regulates the structure of the fibrin 27 clot independently of thrombin generation through direct interaction with fibrin

Chapter 3 Dual role for factor XII in coagulation and 55 fibrinolysis

Chapter 4 Inhibition of activated FXII reduces clot strength, 71 a preliminary report

Chapter 5 Activation of the contact system in patients with a first acute myocardial infarction

Chapter $6 \quad$ Fibrin clot formation and fibrinolysis in patients with coronary stent thrombosis

Chapter $7 \quad$ Ongoing contact activation in patients with hereditary angioedema

Chapter $8 \quad$ Novel insights in genetics of arterial thrombosis

$\begin{array}{lll}\text { Chapter } 9 & \text { General discussion } & 167\end{array}$

$\begin{array}{lr}\text { Summary } & 183\end{array}$

$\begin{array}{lr}\text { Samenvatting } & 187\end{array}$

$\begin{array}{ll}\text { Dankwoord } & 191\end{array}$

$\begin{array}{ll}\text { Publications } & 195\end{array}$

$\begin{array}{lr}\text { Curriculum vitae } & 199\end{array}$ 



\section{Chapter 1}

General introduction and outline of the thesis 



\section{Hemostasis}

The primary role of the hemostatic system is to confine bleeding without causing thrombotic complications. Upon injury to the vessel wall, platelets adhere to the site of trauma and form an aggregate which serves as a primary plug that stops bleeding [1]. At the same time, the proteins of the coagulation system are activated, which leads to the formation of a fibrin clot (see Figure 1.1). Coagulation reactions mainly occur at phospholipid surfaces of platelet membranes, particularly after 'flip-flop' exposure of phosphatidylserine (PS). Activation of the coagulation cascade leads to stepwise activation of serine proteases (which normally circulate as inactive zymogens) to active enzymes. Coagulation can be initiated via two cascades: the extrinsic pathway and the intrinsic pathway of coagulation [2,3].

After endothelial damage, the extrinsic pathway is activated by exposure of tissue factor (TF) to the bloodstream. TF binds to coagulation factor VII(a) (FVIla) and the TF/FVIla complex activates factor X (FX) and FIX. The intrinsic pathway is triggered by activation of FXII in a process called contact activation, which is discussed in more detail further on. Activated FXII (FXIla) activates prekallikrein and $\mathrm{FXI}$, in the presence of the cofactor high molecular weight kininogen (HMWK), and FXla activates FIX. Activated FIX (FIXa) associates with the cofactor FVIIla into the tenase complex (FIXa, FVIIla, $\mathrm{Ca}^{2+}$ and phospholipid membrane) which activates FX. FXa associates with FVa to form the prothrombinase complex ( $\mathrm{FXa}, \mathrm{FVa}, \mathrm{Ca}^{2+}$ and phospholipid membrane) which converts prothrombin into thrombin. Thrombin, in turn, catalyses the conversion of fibrinogen to fibrin. Fibrin molecules polymerize to fibers that are covalently linked by FXIIIa [4]. Thrombin mediates several feedback reactions, including the activation of FXI and FXIII, and the activation of the cofactors FV and FVIII. Furthermore, thrombin initiates an important inhibitory mechanism involving the thrombomodulin mediated activation of protein $\mathrm{C}$. Activated protein C (APC), together with the cofactor protein S, inactivates the cofactors FVIIIa and $\mathrm{FVa}$ and hereby attenuates coagulation. Other important natural anticoagulants include antithrombin (which directly inhibits serine proteases such as thrombin), tissue factor pathway inhibitor (TFPI) and C1-esterase inhibitor $(\mathrm{C} 1-\mathrm{INH})$. 


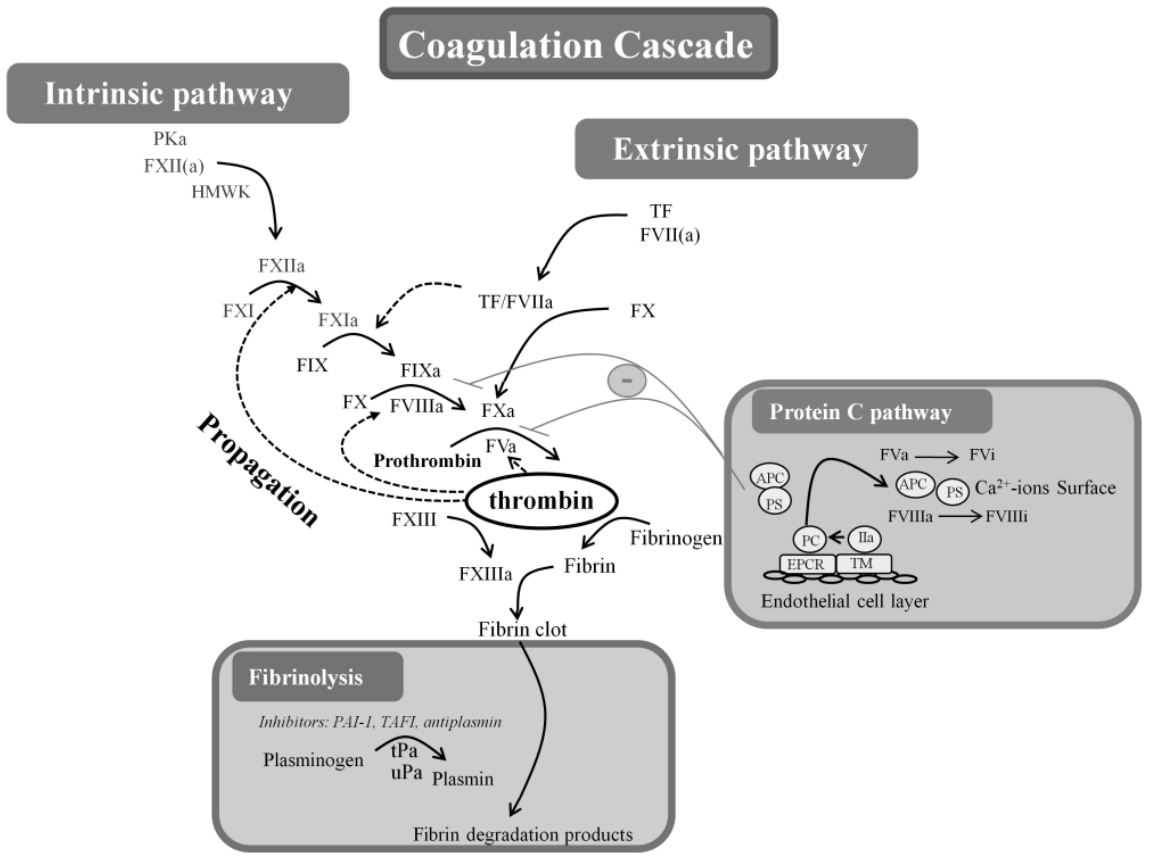

Figure 1.1: Current view of coagulation and related systems.

The coagulation cascade is a sequential activation of coagulation proteins and consists of two pathways initiated by different triggers: the intrinsic pathway and the extrinsic pathway. FXa is the central enzyme common to both the extrinsic and the intrinsic coagulation pathway. After injury, the extrinsic pathway is initiated by the formation of the TF/FVIla complex and cleaves FX to form FXa. The intrinsic pathway is triggered by activation of FXII in a process called contact activation; FXIla will also produce $F X a$ via $\mathrm{FXI}, \mathrm{FIX}$ and $\mathrm{FX}$ activation. FXa associates with $\mathrm{FV}(\mathrm{a})$ on a phospholipid membrane and converts prothrombin (FII) into thrombin. Thrombin forms fibrin out of fibrinogen and activates FXIII. FXIIla polymerizes the fibrin fibers. Clot formation is accelerated by thrombin activation of the cofactors FV and FVIII and by feedback activation of FXI. The TF/FVIla complex can also activate FIX and FX. Thrombin slows down its own formation by activation of the protein C pathway. The formed activated protein C (APC) will inactivate the cofactors FVa and FVIIla. After one week the process of fibrinolysis will dissolve the fibrin clot.

\section{Fibrin formation and fibrinolysis}

The end product of coagulation is the formation of an insoluble fibrin clot, from fibrinogen by thrombin. Fibrinogen is a soluble $340 \mathrm{kDa}$ glycoprotein present at a concentration of $2-4 \mathrm{mg} / \mathrm{ml}$ in plasma. It circulates as a dimer consisting of 2 identical subunits, each formed by three non-identical polypeptide chains: Aa, $\mathrm{B} \beta$ and $\mathrm{y}$. Fibrinogen has an elongated structure with three connected nodules: the central nodule $E$ and two distal nodules $D$. Thrombin converts fibrinogen 
into fibrin monomers by cleaving fibrinopeptide A (FPA) and FPB. These monomers polymerize spontaneously and produce fibrin protofibrils which assemble into fibers. FXIIla, activated by thrombin, cross-links the fibrin fibers by forming $Y$-glutamyl- $\varepsilon$-lysyl amide bonds between the monomers and this stabilizes the fibrin clot [5].

Degradation of the fibrin clot is dependent on the action of the enzyme plasmin. Plasmin is formed from plasminogen by plasminogen activators, among which tissue-type plasminogen activator (tPA) and urokinase plasminogen activator (UPA) are the most important. The conversion of plasminogen into plasmin is controlled at different levels and occurs at the fibrin surface. Fibrinogen is a rather inert molecule, whereas fibrin interacts with a number of proteins, among which IPA and plasmin(ogen). Interaction of plasminogen and TPA with fibrin provides efficient activation of plasminogen by tPA. Moreover fibrin degradation products stimulate fibrinolysis. Thus fibrin plays an active role in its own degradation and hereby restricts fibrinolysis to the site of the blood clot. Initial cleavage of fibrin by plasmin occurs in the aC-domains followed by multiple cleavages between the $\mathrm{D}$ and the $\mathrm{E}$ regions. Such cleavages generate $\mathrm{COOH}$ terminal Lys residues, which provide additional binding sites for plasmin and thus play an important role in the propagation of fibrinolysis. Thrombin-activated fibrinolysis inhibitor (TAFI) competes for these plasminogen binding sites and hereby reduces fibrinolysis. The activity of the enzymes IPA and UPA is inhibited by plasminogen activator inhibitor-1 (PAl-1), which is released from platelets incorporated into the thrombus. The formed plasmin is controlled by $\alpha_{2}$-antiplasmin [6].

The structure of the fibrin clot and the susceptibility to fibrinolysis are important determinants of thrombotic risk [7]. Many factors influence the structure and stability of the clot, including the concentration of thrombin and fibrinogen, fibrinogen (splice) variants and other plasma proteins. High concentrations of thrombin lead to fibrin clots with thin fibers en small pores, properties that make a clot less susceptible to fibrinolysis [8]. Furthermore, the concentration of fibrinogen and fibrinogen splice variants, such as $\gamma^{\prime}$, influence the structure of the fibrin clot. Differential splicing and alternative polyadenylation of the $y$ chain of fibrinogen leads to the formation of a longer $y$-chain called $y^{\prime}$, which results in a clot with thinner fibers, smaller pores, increased branching and increased resistance to fibrinolysis. It is a natural occurring variant and the ratio of "normal" $y$ chain $\left(\gamma_{A}\right)$ to $y^{\prime}$ is a determinant of thrombotic risk [9]. 


\section{Contact activation system}

The contact system consists of three zymogens, factor XII, prekallikrein and factor XI and the nonenzymatic co-factor high molecular weight kininogen (HMWK). The physiological function of the contact activation system in vivo is still unclear. Deficiencies in FXII, prekallikrein or HMWK are not associated with a bleeding tendency and therefore are not essential for hemostasis. Deficiency in FXI is associated with a mild bleeding phenotype, however, it can also be activated by thrombin, bypassing the contact activation system.

\section{Coagulation factor XII}

FXII was discovered in 1955, due to a prolonged clotting time in the aPTT test in an asymptomatic patient, John Hageman (FXII is also referred to as Hageman factor) [10]. FXII is an $80 \mathrm{kDa}$ serine protease that consists of a heavy (353 residues) and a light chain ( 243 residues) held together by a disulfide bond. The plasma concentration of FXII is $\sim 30 \mu \mathrm{g} / \mathrm{ml}(375 \mathrm{nM})$, which is rather high compared to other coagulation factors, but within the same range as prekallikrein and HMWK [11].

Since its discovery it has been found that FXII is involved in several physiological systems. The zymogen FXII plays a role in angiogenesis via the activation of ERK1/2, whereas the enzymatic activity of activated FXII (FXIla) is directed towards several biological substrates. FXIla is able: 1) to initiate the generation of thrombin via the intrinsic pathway of coagulation through activation of $\mathrm{FXI}, 2$ ) to initiate the kallikrein kinin system via the activation of prekallikrein, 3) to initiate fibrinolysis via the activation of plasminogen and 4) to initiate the complement system via the activation of $C 1$ [12].

Several non-physiological and physiological triggers of FXII activation have been identified, but it is still unclear which is the in vivo activator of FXII. Nonphysiologic activators include negatively charged surfaces such as glass, ellagic acid, dextran sulphate (DXS) and kaolin. Physiological activators include sulfatides [13], collagen [14], misfolded proteins [15] and long chain polyphosphates (polyP) produced by bacteria $[16,17]$. The initial step in the activation of FXII is its binding to a negatively charged surface, which induces a conformational change and forms activated FXIla ( $\alpha-F X I l a)$. $\alpha-F X I l a$ is able to activate FXII (autoactivation), prekallikrein and FXI. Furthermore, kallikrein reciprocally activates $\mathrm{FXII}$, and via a second cleavage at R334-N335 converts $\alpha$-FXIla to $\beta$-FXIla (30 kDa). $\beta$-FXIla has lost the heavy chain, which contains the binding sites to a surface [18]. $\beta$-FXIla is still able to activate prekallikrein, but not FXI [19]. Activation of prekallikrein leads to bradykinin formation: 
kallikrein cleaves HMWK and releases the nonapeptide bradykinin. Bradykinin is a pro-inflammatory peptide which increases the vascular permeability and is involved in the regulation of blood pressure. Activation of FXI leads to the activation of the intrinsic pathway of coagulation and the formation of a fibrin clot. It has been proposed that platelets participate in the activation of FXII, however it is still not clear how [20-22].

Both $\alpha-F X I l a$ and $\beta-F X I l a$ are mainly inhibited by the natural inhibitor $\mathrm{C} 1-\mathrm{INH}$, $90 \%$ of FXIla is inhibited by C1-INH in vivo. C1-INH is a serpin which inhibits several enzymes, including $\mathrm{C} 1 \mathrm{~s}$ (hence the name of this inhibitor), FXIla, FXla and kallikrein and its plasma concentration is $240 \mu \mathrm{g} / \mathrm{ml}$ [23]. Patients with a congenital deficiency in $\mathrm{C} 1 \mathrm{INH}$ have a disease called hereditary angioedema, which will be discussed later on in this introduction.

\section{FXII in coagulation and fibrinolysis}

Patients deficient in FXII neither have a bleeding tendency nor a prothrombotic state, therefore, the role of FXII in coagulation and thrombosis has long been debated. However, data from $\mathrm{FXII}^{-1-}$ mice have renewed the interest in the contribution of FXII to thrombosis. $\mathrm{FXII}^{-1-}$ mice were protected in models of arterial thrombosis, pulmonary embolism and ischemic stroke. In these models, thrombosis was induced by an external stress factor such as transient occlusion of an artery, laser induced thrombus formation in the brain, treatment with $\mathrm{FeCl}_{3}$ or the infusion of a mixture of collagen and epinephrine. FXII-deficiency caused thrombus instability that prevented vessel occlusion in these models [24,25]. Administration of purified FXII to $\mathrm{FXII}^{-/}$mice restored induced thrombus formation. Furthermore, pharmacologic inhibition of FXII showed a comparable protective effect. These animal models show that, even though FXII is not essential for hemostasis, at least in mice it is essential for thrombus formation.

The proteins of the contact activation system show a high degree of homology with those of the fibrinolytic pathway: FXII is homologous to TPA whereas FXI and prekallikrein are homologous to plasminogen [26]. Furthermore, FXIla, FXIa and kallikrein are able to stimulate fibrinolysis by activation of plasminogen, even though, compared to TPA and UPA, FXIla, FXla and kallikrein are only weak activators of plasminogen [27].

From clinical studies it is not clear if FXII plays a role in vivo as a procoagulant or as a profibrinolytic enzyme. A deficiency in FXII is not associated with a bleeding tendency or a prothrombotic phenotype [28]. However, studies in FXIIdeficient patients are limited in size, which may mask subtle effects. The results 
of clinical studies into the role of FXII in arterial thrombosis are ambiguous. The levels of FXII in these studies are measured in different ways: the levels of zymogen FXII, the levels of activated FXII and the levels of FXIla in complex with its natural inhibitor $\mathrm{C} 1-\mathrm{INH}$. Furthermore, a common polymorphism in the FXII gene, a $-4 C>T$ substitution in the 5 ' untranslated region, has been described that is associated with lower plasma levels of FXII [29]. In clinical studies all these different FXII tests have been used with different results.

\section{FXII and arterial thrombosis}

Table 1.1 shows an overview of the clinical studies that have investigated the contribution of FXII to arterial thrombosis. Unfortunately, the results of these studies do not point to a clear role for FXII(a) in arterial thrombosis. Elevated levels of FXIla have been found to be associated with coronary heart disease (CHD), coronary calcifications and to predict a recurrent cardiovascular event after acute myocardial infarction (AMI) [30-33]. However, two other studies did not find an association between the levels of FXIla and CHD, AMI or acute coronary syndrome (ACS) $[34,35]$. Healthy men with high or low levels of FXIla$\mathrm{C} 1 \mathrm{INH}$ had an increased risk of $\mathrm{CHD}$ [36]. In women only high levels of FXIla$\mathrm{C} 1 \mathrm{INH}$ were associated with ischemic stroke whereas these levels were not associated with AMI [37]. Furthermore, low levels of FXIIc were associated with an increased risk of AMI, CHD and ACS and all cause-mortality $[34,38,39]$, but again not in all studies [40-42].

The association between the $-4 \mathrm{C}>\mathrm{T}$ polymorphism and arterial thrombosis is not clear either. The TT-genotype was associated with an increased risk of coronary artery disease (CAD) in men with high cholesterol [43]. Pravastatin treatment reduced the risk of CAD in men with a CC or CT genotype, but not in men with a TT genotype [43]. In patients with CAD before the age of 45 , the presence of the $-4 \mathrm{~T}$ allele increased the risk of MI, especially in the presence of hypercholesterolemia. If both risk factors were present, the risk was increased 2.26-fold [44]. The TT-genotype was also associated with CAD and ischemic stroke $[45,46]$; however, in patients with pre-existing CAD the TT-genotype had a protective effect on the development of ACS [47]. Furthermore, several studies did not observe an effect of the polymorphism on arterial thrombosis [34,48-51]. A meta-analysis only found a weak, not statistically significant, association between -4C>T polymorphism and AMI based on 9 studies [52].

Due to the differences in the used tests and the differences in results between the clinical studies, it is still not clear how FXII influences arterial thrombosis. Probably, the effect of FXII on arterial thrombosis differs between groups (men 
versus women, the location of the thrombosis) and is influenced by other cardiovascular risk factors, such as cholesterol levels.

\section{FXII and fibrinolysis}

Few studies have determined the effect of FXII on fibrinolysis in vivo. In a septic baboon model, inhibition of FXIla with a monoclonal antibody prior to the septic challenge, resulted in a reduced activation of the fibrinolytic system. The release of tPA and the appearance of plasmin- $\alpha_{2}$-antiplasmin (PAP) complexes into the circulation of these animals were significantly reduced after treatment compared to control animals [63]. In healthy volunteers, the potential to activate plasminogen after infusion of desamino D-arginine vasopressin (DDAVP) was only partially blocked by specific inhibitors of tPA and UPA. The residual activity could be blocked with a monoclonal antibody that inhibits FXII activity. In patients deficient in FXII, the potential to activate plasminogen was completely blocked by specific tPA and UPA inhibitors. Furthermore, in FXII-deficient patients the amount of plasmin formed after DDAVP-infusion was lower than in healthy controls and the contact system was activated after DDAVP-infusion in healthy volunteers $[64,65]$. 


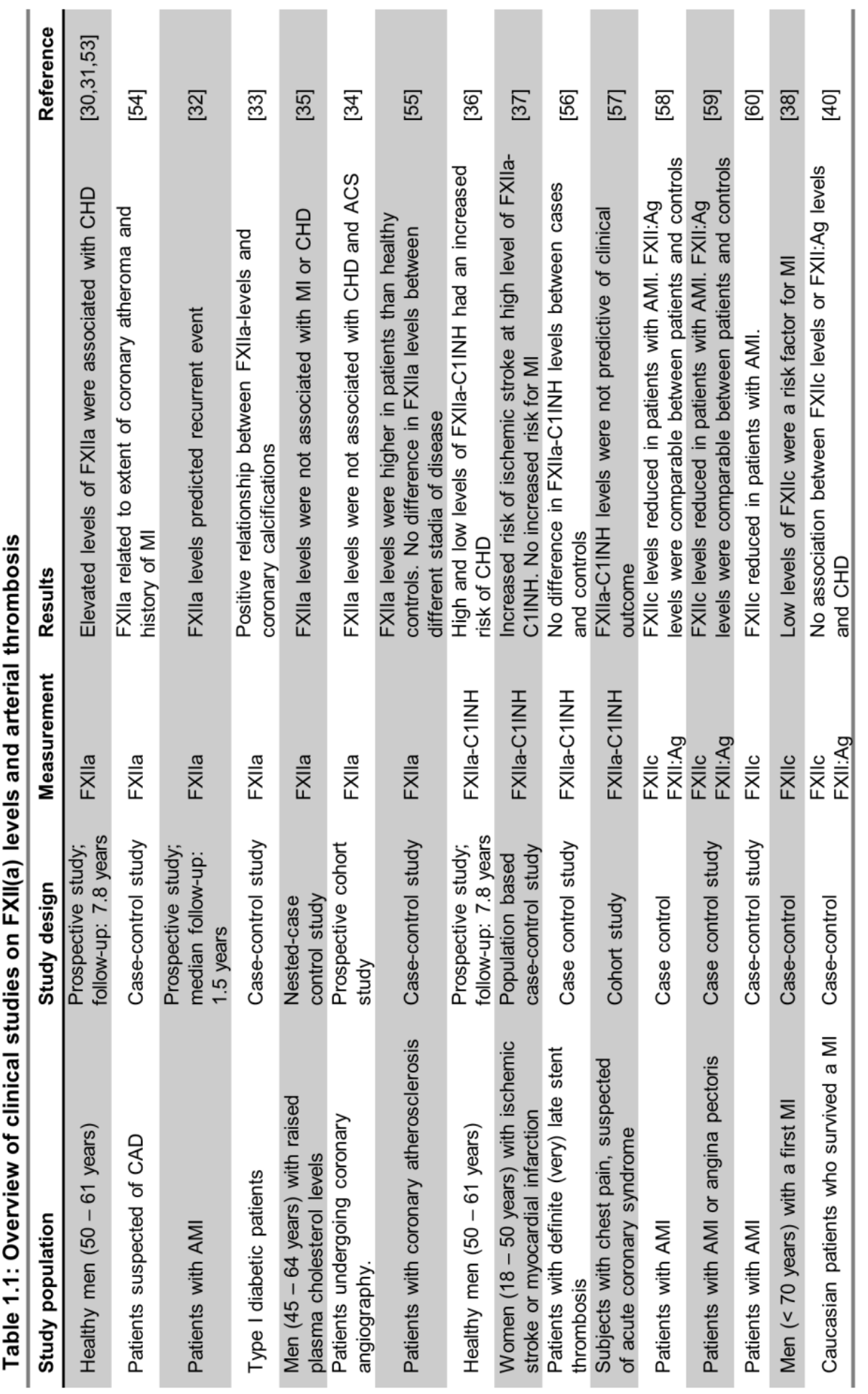




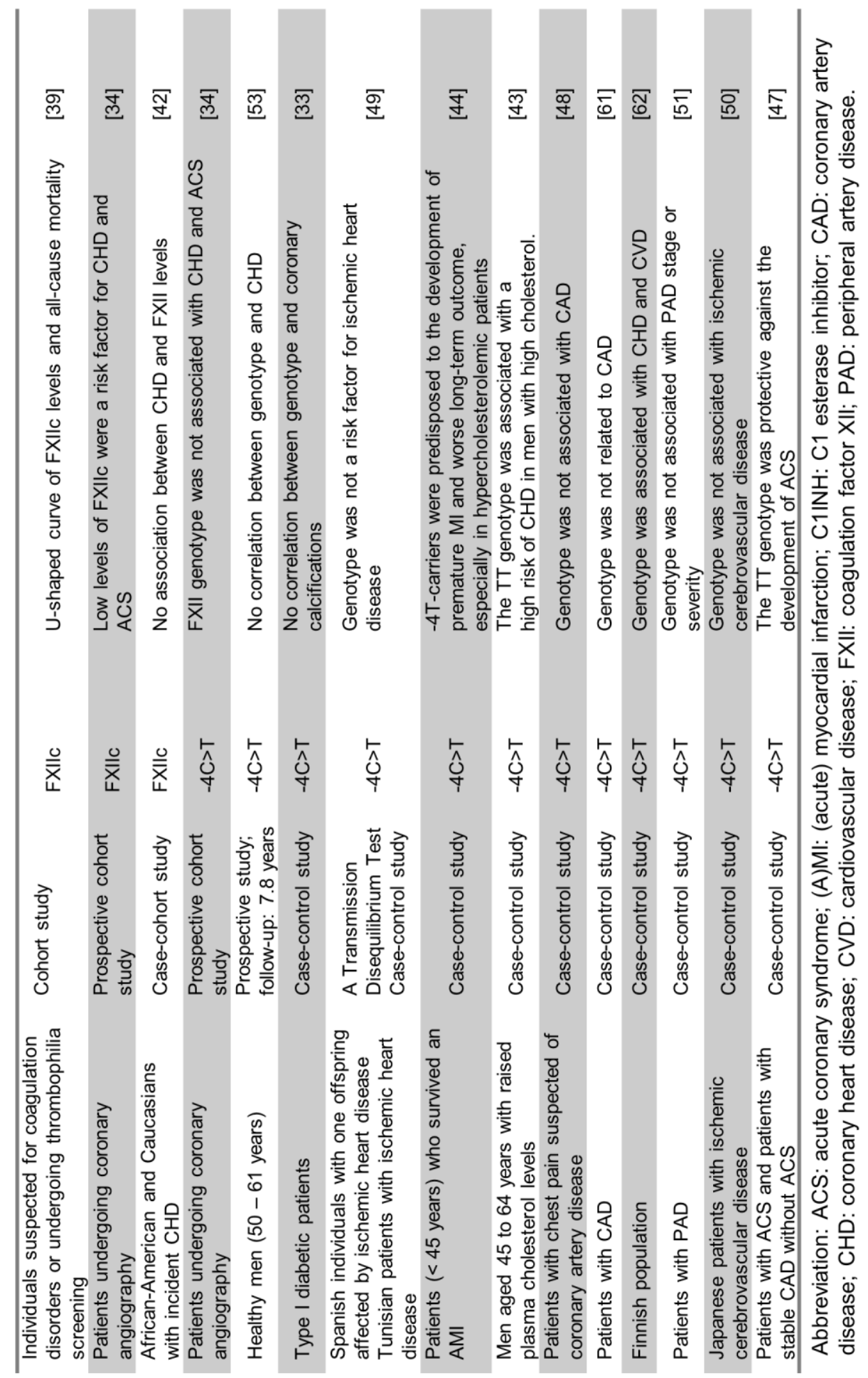




\section{Hereditary angioedema}

Hereditary angioedema (HAE) is a potentially life-threatening disease characterized by episodic attacks of swelling throughout the body. The most common cause of HAE is a genetic defect in the genes coding for $\mathrm{C} 1$-esterase inhibitor (SERPING1) leading to low levels or dysfunctional C1INH (called HAE type I and type II (HAE-C1INH), respectively). C1INH is a serine protease inhibitor that blocks the activity of proteins in the complement system, the contact system of coagulation, and the fibrinolytic system [66]. It is the most important inhibitor of the contact activation system: $90 \%$ of FXIla, 50\% of kallikrein and $50 \%$ of FXla are inhibited by $\mathrm{C} 1 \mathrm{INH}$ in plasma from healthy individuals [67-69]. Attacks of angioedema are caused by an increase in bradykinin. Bradykinin is a vasoactive nonapeptide which acts as a potent vasodilator [70]. Activation of the contact system contributes the formation of bradykinin in HAE-C1INH patients. Bradykinin is formed from HMWK, mainly by the action of kallikrein. Mannose-binding lectin-associated serine protease -1 (MASP-1) is also able to digest HMWK and form bradykinin, however much slower and less efficient than kallikrein [71].

Patients with HAE-C1INH show activation of the contact system: in plasma samples elevated levels of FXIla and cleaved HMWK were measured. Furthermore, markers of coagulation are also increased: the levels of FVIla, prothrombin fragment 1.2 (a marker of thrombin generation) and D-dimer (a marker of fibrin degradation) are increased [72,73]. Even though the contact system and the coagulation system are activated during attacks of angioedema, patient with HAE-C1INH do not have an apparent increased risk of thrombosis.

\section{In-stent thrombosis}

In patients undergoing a percutaneous coronary intervention (PCI), often a coronary artery stent is placed for recanalization. In $1 \%$ to $4 \%$ of patients, after placement of the stent, a thrombus forms within the stent. This is called stent thrombosis (ST). It is an uncommon, but serious complication. Depending on the time after the placement of the stent, ST can be categorized into: 1) acute (within 24 hours after placement of the stent), 2) subacute (within 30 days after placement of the stent), 3) late (1 to 12 months after placement of the stent), or 4) very late (more than one year after placement of the stent).

The main predictors of ST are early antiplatelet therapy discontinuation, extent of coronary disease, and stent number/length [74]. The contribution of platelets to ST is apparent from the fact that dual anti-platelet therapy is effective in 
reducing the incidence of ST [75]. However, a recent clinical trial has shown that inhibition of the coagulation system with the specific FXa inhibitor rivaroxaban reduced the risk of ST even further when combined with antiplatelet therapy [76]. This result highlights that activation of the coagulation system also contributes to ST. It was already shown that changes in the fibrin clot structure and reduced fibrinolysis are associated with an increased risk of in-stent thrombosis [77,78].

\section{Outline of this thesis}

The research presented in this thesis aims to gain more insight into the contribution of the contact system, and mainly FXII, in fibrin clot formation and fibrinolysis. Chapters 2, 3 and 4 describe work which was performed in vitro. In chapter 2 we identified a novel role for FXII and FXIla in fibrin clot formation: FXII(a) interacts with fibrin(ogen) and changes the structure and rigidity of the clot. The structure of the clot is an important determinant of the susceptibility to fibrinolysis, and since FXIla can activate plasminogen we investigated the influence of FXIla on fibrinolysis in chapter 3. In chapter 4, the influence of inhibiting FXIla on the formation and lysis of plasma fibrin clots and whole blood thrombi was investigated.

In chapters 5, 6 and 7 patient studies are described. The contribution of the contact system to arterial thrombosis is not fully understood, therefore, we determined the contribution of the contact system to the development and progression of CAD in patients with a first AMI. In chapter 6 , the fibrin clot formation and fibrinolysis was determined in patients with stent thrombosis. In patients with HAE-C1INH the contact system is poorly controlled, without causing an apparent thrombotic tendency. In chapter 7 we investigated why activation of the contact pathway does not lead to thrombosis in HAE-C1INH patients.

In chapter 8 we reviewed the genetic variation in coagulation factors and platelet receptors and how these variations influence the risk of arterial thrombosis. Finally, chapter 9 summarizes the most important findings and discusses these findings in relation to literature. 


\section{References}

1. Davi G, Patrono C. Platelet activation and atherothrombosis. N Engl J Med. 2007; 357: 2482-94.

2. Macfarlane RG. An Enzyme Cascade in the Blood Clotting Mechanism, and Its Function as a Biochemical Amplifier. Nature. 1964; 202: 498-9.

3. Davie EW, Ratnoff OD. Waterfall Sequence for Intrinsic Blood Clotting. Science. 1964; 145: 1310-2.

4. Standeven KF, Ariens RA, Grant PJ. The molecular physiology and pathology of fibrin structure/function. Blood Rev. 2005; 19: 275-88.

5. Mosesson MW. Fibrinogen and fibrin structure and functions. J Thromb Haemost. 2005; 3: 1894-904.

6. Rijken DC, Lijnen HR. New insights into the molecular mechanisms of the fibrinolytic system. J Thromb Haemost. 2009; 7: 4-13.

7. Undas A, Ariens RA. Fibrin clot structure and function: a role in the pathophysiology of arterial and venous thromboembolic diseases. Arterioscler Thromb Vasc Biol. 2011; 31: e88-99.

8. Wolberg AS. Determinants of fibrin formation, structure, and function. Curr Opin Hematol. 2012; 19: 349-56.

9. Uitte de Willige S, Standeven KF, Philippou H, Ariens RA. The pleiotropic role of the fibrinogen gamma' chain in hemostasis. Blood. 2009; 114: 3994-4001.

10. Ratnoff OD, Margolius A, Jr. Hageman trait: an asymptomatic disorder of blood coagulation. Transactions of the Association of American Physicians. 1955; 68: 149-54.

11. Fuhrer G, Gallimore MJ, Heller W, Hoffmeister HE. FXII. Blut. 1990; 61: 258-66.

12. Renne T, Schmaier AH, Nickel KF, Blomback M, Maas C. In vivo roles of factor XII. Blood. 2012; 120: 4296-303.

13. Tans G, Griffin JH. Initiation of contact activation by sulfatides. Advances in experimental medicine and biology. 1983; 156: 63-72.

14. van der Meijden PE, Munnix IC, Auger JM, Govers-Riemslag JW, Cosemans JM, Kuijpers MJ, Spronk HM, Watson SP, Renne T, Heemskerk JW. Dual role of collagen in factor XII-dependent thrombus formation. Blood. 2009; 114: 881-90.

15. Maas C, Govers-Riemslag JW, Bouma B, Schiks B, Hazenberg BP, Lokhorst HM, Hammarstrom P, ten Cate H, de Groot PG, Bouma BN, Gebbink MF. Misfolded proteins activate factor XII in humans, leading to kallikrein formation without initiating coagulation. J Clin Invest. 2008; 118: 3208-18.

16. Smith SA, Mutch NJ, Baskar D, Rohloff P, Docampo R, Morrissey JH. Polyphosphate modulates blood coagulation and fibrinolysis. Proceedings of the National Academy of Sciences of the United States of America. 2006; 103: 903-8.

17. Morrissey JH, Choi SH, Smith SA. Polyphosphate: an ancient molecule that links platelets, coagulation, and inflammation. Blood. 2012; 119: 5972-9.

18. Stavrou E, Schmaier AH. Factor XII: what does it contribute to our understanding of the physiology and pathophysiology of hemostasis \& thrombosis. Thromb Res. 2010; 125: 210-5.

19. Revak SD, Cochrane CG, Bouma BN, Griffin JH. Surface and fluid phase activities of two forms of activated Hageman factor produced during contact activation of plasma. J Exp Med. 1978; 147: 719-29.

20. Back J, Sanchez J, Elgue G, Ekdahl KN, Nilsson B. Activated human platelets induce factor XIla-mediated contact activation. Biochemical and biophysical research communications. 2010; 391: 11-7. 
21. Johne J, Blume C, Benz PM, Pozgajova M, Ullrich M, Schuh K, Nieswandt B, Walter U, Renne T. Platelets promote coagulation factor XII-mediated proteolytic cascade systems in plasma. Biological chemistry. 2006; 387: 173-8.

22. Walsh PN, Griffin JH. Platelet-coagulant protein interactions in contact activation. Ann N Y Acad Sci. 1981; 370: 241-52.

23. Zeerleder S. C1-inhibitor: more than a serine protease inhibitor. Semin Thromb Hemost. 2011; 37: 362-74.

24. Renne T, Pozgajova M, Gruner S, Schuh K, Pauer HU, Burfeind P, Gailani D, Nieswandt B. Defective thrombus formation in mice lacking coagulation factor XII. $J$ Exp Med. 2005; 202: 271-81.

25. Kleinschnitz C, Stoll G, Bendszus M, Schuh K, Pauer HU, Burfeind P, Renne C, Gailani D, Nieswandt B, Renne T. Targeting coagulation factor XII provides protection from pathological thrombosis in cerebral ischemia without interfering with hemostasis. J Exp Med. 2006; 203: 513-8.

26. Ponczek MB, Gailani D, Doolittle RF. Evolution of the contact phase of vertebrate blood coagulation. J Thromb Haemost. 2008; 6: 1876-83.

27. Miles LA, Greengard JS, Griffin JH. A comparison of the abilities of plasma kallikrein, beta-Factor XIla, Factor Xla and urokinase to activate plasminogen. Thromb Res. 1983; 29: 407-17.

28. Girolami A, Morello M, Girolami B, Lombardi AM, Bertolo C. Myocardial infarction and arterial thrombosis in severe (homozygous) FXII deficiency: no apparent causative relation. Clin Appl Thromb Hemost. 2005; 11: 49-53.

29. Kanaji T, Okamura T, Osaki K, Kuroiwa M, Shimoda K, Hamasaki N, Niho Y. A common genetic polymorphism (46 C to T substitution) in the 5'-untranslated region of the coagulation factor XII gene is associated with low translation efficiency and decrease in plasma factor XII level. Blood. 1998; 91: 2010-4.

30. Cooper JA, Miller GJ, Bauer KA, Morrissey JH, Meade TW, Howarth DJ, Barzegar $S$, Mitchell JP, Rosenberg RD. Comparison of novel hemostatic factors and conventional risk factors for prediction of coronary heart disease. Circulation. 2000; 102: 2816-22.

31. Miller GJ, Esnouf MP, Burgess AI, Cooper JA, Mitchell JP. Risk of coronary heart disease and activation of factor XII in middle-aged men. Arterioscler Thromb Vasc Biol. 1997; 17: 2103-6.

32. Grundt H, Nilsen DW, Hetland O, Valente E, Fagertun HE. Activated factor 12 (FXIla) predicts recurrent coronary events after an acute myocardial infarction. $A m$ Heart J. 2004; 147: 260-6.

33. Colhoun HM, Zito F, Norman Chan N, Rubens MB, Fuller JH, Humphries SE. Activated factor XII levels and factor XII 46C>T genotype in relation to coronary artery calcification in patients with type 1 diabetes and healthy subjects. Atherosclerosis. 2002; 163: 363-9.

34. Bach J, Endler G, Winkelmann BR, Boehm BO, Maerz W, Mannhalter C, Hellstern P. Coagulation factor XII (FXII) activity, activated FXII, distribution of FXII C46T gene polymorphism and coronary risk. J Thromb Haemost. 2008; 6: 291-6.

35. Lowe GD, Rumley A, McMahon AD, Ford I, O'Reilly DS, Packard CJ. Interleukin-6, fibrin D-dimer, and coagulation factors VII and XIla in prediction of coronary heart disease. Arterioscler Thromb Vasc Biol. 2004; 24: 1529-34.

36. Govers-Riemslag JW, Smid M, Cooper JA, Bauer KA, Rosenberg RD, Hack CE, Hamulyak K, Spronk HM, Miller GJ, ten Cate H. The plasma kallikrein-kinin system and risk of cardiovascular disease in men. J Thromb Haemost. 2007; 5: 1896-903.

37. Siegerink B, Govers-Riemslag JW, Rosendaal FR, Ten Cate H, Algra A. Intrinsic coagulation activation and the risk of arterial thrombosis in young women: results from the Risk of Arterial Thrombosis in relation to Oral contraceptives (RATIO) case-control study. Circulation. 2010; 122: 1854-61. 
38. Doggen CJ, Rosendaal FR, Meijers JC. Levels of intrinsic coagulation factors and the risk of myocardial infarction among men: Opposite and synergistic effects of factors XI and XII. Blood. 2006; 108: 4045-51.

39. Endler G, Marsik C, Jilma B, Schickbauer T, Quehenberger P, Mannhalter C. Evidence of a U-shaped association between factor XII activity and overall survival. J Thromb Haemost. 2007; 5: 1143-8.

40. Merlo C, Wuillemin WA, Redondo M, Furlan M, Sulzer I, Kremer-Hovinga J, Binder BR, Lammle B. Elevated levels of plasma prekallikrein, high molecular weight kininogen and factor XI in coronary heart disease. Atherosclerosis. 2002; 161: 2617.

41. Kelleher CC, Mitropoulos KA, Imeson J, Meade TW, Martin JC, Reeves BE, Hughes LO. Hageman factor and risk of myocardial infarction in middle-aged men. Atherosclerosis. 1992; 97: 67-73.

42. Yamagishi K, Aleksic N, Hannan PJ, Folsom AR. Coagulation factors II, V, IX, X, $\mathrm{XI}$, and XII, plasminogen, and alpha-2 antiplasmin and risk of coronary heart disease. Journal of atherosclerosis and thrombosis. 2010; 17: 402-9.

43. Zito F, Lowe GD, Rumley A, McMahon AD, Humphries SE. Association of the factor XII 46C>T polymorphism with risk of coronary heart disease (CHD) in the WOSCOPS study. Atherosclerosis. 2002; 165: 153-8.

44. Roldan V, Corral J, Marin F, Pineda J, Vicente V, Gonzalez-Conejero R. Synergistic association between hypercholesterolemia and the C46T factor XII polymorphism for developing premature myocardial infarction. Thromb Haemost. 2005; 94: 1294-9.

45. Santamaria A, Martinez-Rubio A, Mateo J, Tirado I, Soria JM, Fontcuberta J. Homozygosity of the T allele of the $46 \mathrm{C}-->\mathrm{T}$ polymorphism in the $\mathrm{F} 12$ gene is a risk factor for acute coronary artery disease in the Spanish population. Haematologica. 2004; 89: 878-9.

46. Santamaria A, Mateo J, Tirado I, Oliver A, Belvis R, Marti-Fabregas J, Felices R, Soria JM, Souto JC, Fontcuberta J. Homozygosity of the T allele of the $46 \mathrm{C}->\mathrm{T}$ polymorphism in the F12 gene is a risk factor for ischemic stroke in the Spanish population. Stroke. 2004; 35: 1795-9.

47. Endler G, Mannhalter C, Sunder-Plassmann H, Lalouschek W, Kapiotis S, Exner M, Jordanova N, Meier S, Kunze F, Wagner O, Huber K. Homozygosity for the C-$>$ T polymorphism at nucleotide 46 in the $5^{\prime}$ untranslated region of the factor XII gene protects from development of acute coronary syndrome. $\mathrm{Br} \mathrm{J}$ Haematol. 2001; 115: 1007-9.

48. Kohler HP, Futers TS, Grant PJ. FXII (46C-->T) polymorphism and in vivo generation of FXII activity--gene frequencies and relationship in patients with coronary artery disease. Thromb Haemost. 1999; 81: 745-7.

49. Athanasiadis G, Esteban E, Vidal MG, Torres RC, Bahri R, Moral P. Polymorphism FXII 46C>T and cardiovascular risk: additional data from Spanish and Tunisian patients. BMC Res Notes. 2009; 2: 154.

50. Oguchi S, Ito D, Murata M, Yoshida T, Tanahashi N, Fukuuchi Y, Ikeda Y, Watanabe K. Genotype distribution of the $46 \mathrm{C} / \mathrm{T}$ polymorphism of coagulation factor XII in the Japanese population: absence of its association with ischemic cerebrovascular disease. Thromb Haemost. 2000; 83: 178-9.

51. Yazdani-Biuki B, Krippl P, Brickmann K, Fuerst F, Langsenlehner U, Paulweber B, Pilger E, Wascher T, Brezinschek HP, Renner W. The Functional Promoter Polymorphism of the Coagulation Factor XII Gene is not Associated With Peripheral Arterial Disease. Angiology. 2009.

52. Johnson CY, Tuite A, Morange PE, Tregouet DA, Gagnon F. The factor XII -4C>T variant and risk of common thrombotic disorders: A HuGE review and meta- 
analysis of evidence from observational studies. American journal of epidemiology. 2011; 173: 136-44.

53. Zito F, Drummond F, Bujac SR, Esnouf MP, Morrissey JH, Humphries SE, Miller GJ. Epidemiological and genetic associations of activated factor XII concentration with factor VII activity, fibrinopeptide A concentration, and risk of coronary heart disease in men. Circulation. 2000; 102: 2058-62.

54. Kohler HP, Carter AM, Stickland MH, Grant PJ. Levels of activated FXII in survivors of myocardial infarction--association with circulating risk factors and extent of coronary artery disease. Thromb Haemost. 1998; 79: 14-8.

55. Altieri P, Devoto E, Spallarossa P, Rossettin P, Garibaldi S, Bertero G, Balbi M, Barsotti A, Brunelli C, Ghigliotti G. Acute coronary syndromes do not promote prolonged in vivo FXII-dependent prothrombotic activity. Thromb Res. 2005; 115: 65-72.

56. Ponitz V, Govers-Riemslag JW, Ten Cate $H$, van Oerle R, Brugger-Andersen $T$, Grundt H, Naesgaard P, Pritchard D, Larsen Al, Nilsen DW. A history of late and very late stent thrombosis is not associated with increased activation of the contact system, a case control study. Thrombosis journal. 2010; 8: 6.

57. Ponitz V, Govers-Riemslag JW, Brugger-Andersen T, ten Cate H, Nilsen DW. Inhibitor complexes of the plasma kallikrein-kinin system and outcome prediction in patients following admission for chest pain. J Thromb Haemost. 2009; 7: 1231-3.

58. Tanaka M, Suzuki A. Hemostatic abnormalities in acute myocardial infarction as detected by specific blood markers. Thromb Res. 1994; 76: 289-98.

59. Vaziri ND, Kennedy SC, Kennedy D, Gonzales E. Coagulation, fibrinolytic, and inhibitory proteins in acute myocardial infarction and angina pectoris. Am J Med. 1992; 93: 651-7.

60. La Follette L, Gordon EM, Mazur CA, Ratnoff OD, Yamashita TS. Hyperprolactinemia and reduction in plasma titers of Hageman factor, prekallikrein, and high molecular weight kininogen in patients with acute myocardial infarction. The Journal of laboratory and clinical medicine. 1987; 110: 318-21.

61. Caamano J, Jaramillo PC, Lanas C, Lanas F, Salazar LA. Factor XII 46C --> T gene polymorphism in Chilean subjects with coronary artery disease and controls. Medical principles and practice : international journal of the Kuwait University, Health Science Centre. 2009; 18: 137-42.

62. Silander K, Alanne M, Kristiansson K, Saarela O, Ripatti S, Auro K, Karvanen J, Kulathinal S, Niemela M, Ellonen P, Vartiainen E, Jousilahti $P$, Saarela J, Kuulasmaa K, Evans A, Perola M, Salomaa V, Peltonen L. Gender differences in genetic risk profiles for cardiovascular disease. PLoS One. 2008; 3: e3615.

63. Jansen PM, Pixley RA, Brouwer M, de Jong IW, Chang AC, Hack CE, Taylor FB, Jr., Colman RW. Inhibition of factor XII in septic baboons attenuates the activation of complement and fibrinolytic systems and reduces the release of interleukin- 6 and neutrophil elastase. Blood. 1996; 87: 2337-44.

64. Levi M, Hack CE, de Boer JP, Brandjes DP, Buller HR, ten Cate JW. Reduction of contact activation related fibrinolytic activity in factor XII deficient patients. Further evidence for the role of the contact system in fibrinolysis in vivo. J Clin Invest. 1991; 88: 1155-60.

65. Levi M, Hack CE, de Boer JP, Brandjes DP, Buller HR, ten Cate JW. Contact system dependent fibrinolytic activity in vivo: observations in healthy subjects and factor XII deficient patients. Agents Actions Suppl. 1992; 38 ( Pt 2): 292-8.

66. Silverman GA, Bird PI, Carrell RW, Church FC, Coughlin PB, Gettins PG, Irving JA, Lomas DA, Luke CJ, Moyer RW, Pemberton PA, Remold-O'Donnell E, Salvesen GS, Travis J, Whisstock JC. The serpins are an expanding superfamily of structurally similar but functionally diverse proteins. Evolution, mechanism of 
inhibition, novel functions, and a revised nomenclature. J Biol Chem. 2001; 276: 33293-6.

67. Pixley RA, Schapira M, Colman RW. The regulation of human factor Xlla by plasma proteinase inhibitors. J Biol Chem. 1985; 260: 1723-9.

68. van der Graaf F, Keus JF, Koedam JA, Rietveld A, Bouma BN. Prekallikrein activation and kallikrein inactivation in human plasma. Adv Exp Med Biol. 1983; 156: $143-8$.

69. Wuillemin WA, Minnema M, Meijers JC, Roem D, Eerenberg AJ, Nuijens JH, ten Cate $\mathrm{H}$, Hack $\mathrm{CE}$. Inactivation of factor Xla in human plasma assessed by measuring factor Xla-protease inhibitor complexes: major role for $\mathrm{C} 1$-inhibitor. Blood. 1995; 85: 1517-26.

70. Cugno $M$, Nussberger J, Cicardi $M$, Agostoni A. Bradykinin and the pathophysiology of angioedema. Int Immunopharmacol. 2003; 3: 311-7.

71. Dobo J, Major B, Kekesi KA, Szabo I, Megyeri M, Hajela K, Juhasz G, Zavodszky $P$, Gal P. Cleavage of kininogen and subsequent bradykinin release by the complement component: mannose-binding lectin-associated serine protease (MASP)-1. PLoS One. 2011; 6: e20036.

72. Cugno M, Zanichelli A, Bellatorre AG, Griffini S, Cicardi M. Plasma biomarkers of acute attacks in patients with angioedema due to $\mathrm{C} 1$-inhibitor deficiency. Allergy. 2009; 64: 254-7.

73. Cugno M, Cicardi M, Bottasso B, Coppola R, Paonessa R, Mannucci PM, Agostoni A. Activation of the coagulation cascade in C1-inhibitor deficiencies. Blood. 1997; 89: 3213-8.

74. D'Ascenzo F, Bollati $M$, Clementi $F$, Castagno $D$, Lagerqvist $B$, de la Torre Hernandez JM, Ten Berg JM, Brodie BR, Urban P, Jensen LO, Sardi G, Waksman R, Lasala JM, Schulz S, Stone GW, Airoldi F, Colombo A, Lemesle G, Applegate RJ, Buonamici $P$, et al. Incidence and predictors of coronary stent thrombosis: Evidence from an international collaborative meta-analysis including 30 studies, 221,066 patients, and 4276 thromboses. Int J Cardiol. 2012.

75. Leon MB, Baim DS, Popma JJ, Gordon PC, Cutlip DE, Ho KK, Giambartolomei A, Diver DJ, Lasorda DM, Williams DO, Pocock SJ, Kuntz RE. A clinical trial comparing three antithrombotic-drug regimens after coronary-artery stenting. Stent Anticoagulation Restenosis Study Investigators. N Engl J Med. 1998; 339: 1665-71.

76. Michael Gibson C, Chakrabarti AK, Mega J, Bode C, Bassand JP, Verheugt FW, Bhatt DL, Goto S, Cohen M, Mohanavelu S, Burton P, Stone G, Braunwald E. Reduction of Stent Thrombosis in Patients with Acute Coronary Syndrome Treated with Rivaroxaban in ATLAS ACS 2-TIMI 51. Journal of the American College of Cardiology. 2013.

77. Undas A, Zalewski J, Krochin M, Siudak Z, Sadowski M, Pregowski J, Dudek D, Janion M, Witkowski A, Zmudka K. Altered plasma fibrin clot properties are associated with in-stent thrombosis. Arterioscler Thromb Vasc Biol. 2010; 30: 27682.

78. Pankiw-Bembenek O, Zalewski J, Goralczyk T, Undas A. A history of early stent thrombosis is associated with prolonged clot lysis time. Thromb Haemost. 2012; 107: 513-20. 


\section{Chapter 2}

\section{Factor XIla regulates the structure of the fibrin clot independently of thrombin generation through direct interaction with fibrin}

J. Konings *, J.W.P. Govers-Riemslag *, H. Philippou, N.J. Mutch, J.I. Borissoff, P. Allan, S. Mohan, G. Tans, H. ten Cate and R.A.S. Ariëns

* These authors contributed equally to this research

This research was originally published in Blood. 2011; 118: 3942-51 (c) the American Society of Hematology. 


\section{Chapter 2}

\section{Abstract}

Recent data indicate an important contribution of coagulation factor $(F) X I I$ to in vivo thrombus formation. Since fibrin structure plays a key role in clot stability and thrombosis we hypothesized that FXII(a) interacts with fibrin(ogen) and thereby regulates clot structure and function.

In plasma and purified systems, we observed a dose-dependent increase in fibrin fiber density and decrease in turbidity, reflecting a denser structure, and a non-linear increase in clot stiffness with FXIla. In plasma, this increase was partly independent of thrombin generation, as shown in clots made in prothrombin deficient plasma initiated with a snake venom enzyme and in clots made from plasma deficient in FXII and prothrombin. Purified FXII and $\alpha-F X I l a$, but not $\beta$-FXIla, bound to purified fibrinogen and fibrin with nanomolar affinity. Immunostaining of human carotid artery thrombi showed that FXII co-localized with areas of dense fibrin deposition, providing evidence for the in vivo modulation of fibrin structure by FXIla.

These data demonstrate that $\alpha$-FXIla modulates fibrin clot structure independently of thrombin generation through direct binding of the $\mathrm{N}$-terminus of FXIla to fibrin(ogen). Modification of fibrin structure by $\alpha$-FXIla represents a novel physiological role for the contact pathway which may contribute to the pathophysiology of thrombosis. 


\section{Introduction}

Blood coagulation culminates in the formation of fibrin which binds platelets and forms a clot. Fibrin is formed from fibrinogen via cleavage of two fibrinopeptides from the $A \alpha-$ and $B \beta$-chains $N$-termini, located in the E-region, by thrombin [1]. Fibrinopeptide cleavage exposes binding sites for complementary sites in the $\mathrm{D}$ region, triggering polymerization and the production of protofibrils. Protofibrils aggregate laterally to form fibers, which branch out and form a threedimensional network [2]. There is increasing evidence that the structure of fibrin regulates thrombosis. Dense fibrin clots with small pores and increased fiber density are more resistant to lysis [3]. Structural characteristics affect the mechanical properties of fibrin [4]. Both venous and arterial thrombosis have been associated with the formation of an altered fibrin network [5-10].

The role of factor (F)XII in hemostasis has long been contested, since deficiency in FXII, unlike deficiencies of other coagulation factors, does not lead to a bleeding diathesis in humans [11] or in mice [12]. However, recent in vivo data show that FXII-deficiency or inhibition in rodent models reduces thrombus formation whilst maintaining normal hemostasis [12-15]. These findings indicate the existence of FXII-related mechanisms that are preferentially involved in thrombosis but not hemostasis.

Contact activation is triggered by the binding of FXII ( $80 \mathrm{kDa})$ to a negatively charged surface, and involves the formation of $\alpha-F X I l a$ via autocatalysis. Bound $\alpha-F X I l a$ converts prekallikrein into kallikrein. Kallikrein can further convert $\alpha$ FXIla to $\beta$-FXIla by an additional cleavage at R334-N335. $\alpha$-FXIla consists of a heavy and light chain that are disulphide linked $(80 \mathrm{kDa})$, whereas $\beta$-FXIla (28 $\mathrm{kDa}$ ) lacks the heavy chain and loses its capacity to bind to negatively charged surfaces [16]. The N-terminal region of FXII ( $\alpha-F X I l a$ heavy chain) shows strong homology with tissue-type plasminogen activator (tPA), with the presence of Fibronectin Type I, Epidermal Growth Factor and Kringle domains [17,18].

In view of the homology between FXII and TPA and in search for a mechanism by which to explain the differential roles of FXII in thrombosis and hemostasis, we hypothesized that FXII(a) interacts with fibrin(ogen) and regulates clot structure and function. We find that FXII(a) binds to fibrin(ogen), largely via its $\mathrm{N}$-terminus, and that this interaction leads to changes in fibrin structure, elasticity and susceptibility to lysis, in part independently of thrombin generation. 


\section{Chapter 2}

\section{Material and methods}

\section{$\underline{\text { Reagents }}$}

Human plasminogen-free fibrinogen, FXII, $\alpha-F X I l a, \beta-F X I l a$ and thrombin were from Enzyme Research Laboratories (Swansea, UK). Fibrinogen AlexaFluor488 was from Molecular probes, Invitrogen (Carlsbad, CA). Congenital FXII-deficient plasma was from George King Bio-medical (St Overland Park, KS). Immunodepleted FXII-deficient plasma was from American Diagnostica (Stamford, CT). Corn trypsin inhibitor (CTI), normal citrated plasma immunodepleted of prothrombin, polyclonal sheep anti-human prothrombin and monoclonal anti-human prothrombin were from Haematologic Technologies (Essex Junction, VT). CNBr-activated sepharose 4B and protein G-Sepharose 4 Fast Flow were from GE Healthcare Bio-Sciences (Uppsala, Sweden). PPACK (H-D-Phe-Pro-Arg-chloromethylketone, 2HCL) was from Calbiochem (La Jolla, $\mathrm{CA}$ ). Sulfatides, benzamidine and bovine serum albumin (BSA) were from Sigma. Chromogenic substrates S-2238 and S-2302 were from Chromogenix (Milano, Italy). Recombinant t-PA was from Boehringer Ingelheim (Alkmaar, the Netherlands). Synthetic phospholipids DOPS, DOPC, DOPE (1,2-dioleoyl-snglycero-3-phosphoserine, 1,2-dioeoyl-sn-glycero-3-phosphocholine, 1,2dioleoyl-snglycero-3-phosphoethanolamine) were from Avanti Polar lipids Inc. (Alabaster, $\mathrm{AL}$ ) and were prepared by sonication as described earlier (DOPS/DOPC/DOPE, 20/60/20, $\mathrm{mol} / \mathrm{mol} / \mathrm{mol}$ ) [19]. Ecarin was from Pentapharm (Basel, Switzerland). Ancrod was from WHO International Laboratory for Biological Standards (Hertfordshire, UK) and recombinant hirudin was from Hyphen BioMed (Andrésy, France). Polyclonal sheep anti human fibrinogen and polyclonal goat anti human FXII were from Affinity Biologicals (Ancaster, Canada), polyclonal rabbit anti-human fibrinogen (1:200, \#A0080) was from Dako (Ely, UK), monoclonal mouse anti-human fibrin (1:200, LSC23559) was from Lifespan Biosciences (Seattle, WA) and monoclonal mouse anti-human FXII (1:50) was in house [20].

\section{Fibrin formation and fibrinolysis by turbidity}

Fibrin polymerization of purified proteins or plasma was monitored in low binding polystyrene 96-well plates (Greiner, Frickenhauser, Germany) by the change in turbidity at $405 \mathrm{~nm}\left(\mathrm{~A}_{405}\right)$ every $15 \mathrm{~s}$, for at least 1.5 hours at $37^{\circ} \mathrm{C}$ using a ELx808 plate reader (Biotek Instruments, Winooski, VT).

Thrombin $(0-5 \mathrm{nM})$ and $\mathrm{CaCl}_{2}(5 \mathrm{mM})$ were incubated at $37^{\circ} \mathrm{C}$ for 10 minutes in the 96-well plates after which fibrinogen $(1 \mathrm{mg} / \mathrm{ml})$, preincubated with $\alpha$-FXIla $(0-125 \mathrm{nM}), \beta$-FXIla $(94 \mathrm{nM})$ or FXII $(94 \mathrm{nM})$ in Hepes-buffer (25 mM Hepes pH 
$7.4,150 \mathrm{mM} \mathrm{NaCl}$ ) for 10 minutes at $37^{\circ} \mathrm{C}$, was added. All concentrations are final concentrations.

To congenital FXII-deficient plasma (final concentration: 76\%) we added FXII (0 - 100\%; normal FXII concentration: $375 \mathrm{nM}$ [21]) and fibrin formation was initiated with sulfatide $(4 \mu \mathrm{M})$, a natural activator of FXII present in mammalian tissue [22] and $\mathrm{CaCl}_{2}(16 \mathrm{mM})$, in the presence of phospholipid vesicles $(4 \mu \mathrm{M})$. To monitor fibrinolysis, tPA $(0.1 \mu \mathrm{g} / \mathrm{ml})$ was added to the clotting mixture. Clot lysis time (to $50 \%$ lysis) was calculated as the time between maximal and halfmaximal turbidity.

\section{Inhibition with PPACK}

To inhibit the enzymatic activity of $\alpha-F X I l a, \alpha-F X I l a(250 \mathrm{nM})$ was incubated with PPACK (1000 nM) for 30 minutes at room temperature, in Hepes-buffer $(25 \mathrm{mM}$ Hepes, $\mathrm{pH}=7.4,150 \mathrm{mM} \mathrm{NaCl}, 1 \mathrm{mg} / \mathrm{ml} \mathrm{BSA}$ ). After incubation, the free PPACK was extensively dialyzed. Using chromogenic substrates, inhibition of FXIla (S-2302) and removal of PPACK (determined by the inhibition of thrombin with $\mathrm{S}-2238$ ) were determined.

\section{Confocal / Two-photon microscopy}

Fibrinogen $(0.5 \mathrm{mg} / \mathrm{ml})$ or diluted plasma $(25 \%)$ were added to a microchamber ( $\mu$-slide VI for Live Cell analysis; ibidi 80601) together with 5\% AlexaFluor488 fibrinogen. After addition of $\mathrm{CaCl}_{2}(5 \mathrm{mM})$ and thrombin $(0.625 \mathrm{nM})$, sulfatides $(0.4 \mu \mathrm{M})$ or ancrod $(0.1 \mathrm{U} / \mathrm{ml})$, clots were formed for minimally two hours in the dark, in a moist atmosphere at room temperature. Experiments in plasma were performed in the presence of phospholipid vesicles $(4 \mu \mathrm{M})$.

Purified fibrinogen was incubated with $\alpha-F X I l a(0-30 \mathrm{nM}), \beta-F X I l a(0-30 \mathrm{nM})$ or FXII $(0-30 \mathrm{nM})$. To congenital FXII-deficient plasma and double deficient plasma (deficient in FXII and prothrombin), we added purified FXII $(0-100 \%$ in undiluted plasma) activated with sulfatides. To plasma immunodepleted of prothrombin we added hirudin (final concentration: $30 \mathrm{nM}$ ) to block residual thrombin activity and $\alpha-F X l l a(30 \mathrm{nM})$ or CTI $(75 \mu \mathrm{g} / \mathrm{ml})$.

For laser scanning confocal microscopy (Upright Zeiss LSM-510 META Axioplan 2), clots were visualized using a $40 \mathrm{X}$ oil immersion lens. AlexaFluor488 fibrinogen was excited with a $488 \mathrm{~nm}$ argon laser. Images were averaged eight times. For the two-photon laser scanning microscopy [23], images were recorded with an Eclipse E600FN upright microscope (Nikon, Tokyo, Japan) equipped with a Radiance 2100MP optical imaging system (BioRad, Hemel Hampstead, United Kingdom). Fluorophores were excited by a 


\section{Chapter 2}

Spectra-Physics Tsunami Ti:Sapphire laser (Spectra-Physics, Mountain View, CA) mode-locked at $800 \mathrm{~nm}$. Images were obtained with a 40X oil immersion lens and fluorescence was detected at 520-560 nm. Further magnification was achieved by optical zoom in the scan head. Images were taken in five different areas of the clot. ImageJ (1.43, National Institutes of Health) was used to determine fiber density, by counting the number of fibers crossing lines of 100 $\mu \mathrm{m}$ placed in the image using the plugin grid.

\section{Scanning electron microscopy}

Scanning electron microscopy (EM) was carried out as described [24] with the following modifications. Clots were formed by mixing fibrinogen $(1 \mathrm{mg} / \mathrm{ml})$ with $0.25 \mathrm{U} / \mathrm{ml}$ thrombin and $5 \mathrm{mM} \mathrm{CaCl}_{2}$ in the absence and presence of $\alpha-\mathrm{FXIla}(0$, 31.25 or $125 \mathrm{nM}$ ) in $20 \mathrm{mM}$ Hepes pH 7.4; $150 \mathrm{mM} \mathrm{NaCl}$. After 2 hours at room temperature, clots were washed in sodium cacodylate buffer and fixed overnight in $2 \%$ glutaraldehyde. Clots were dehydrated with an acetone gradient and sputter coated with platinum palladium. Plasma clots were prepared in a similar manner using immunodepleted FXII-deficient plasma with $0.1 \mathrm{U} / \mathrm{ml}$ thrombin, 10 $\mathrm{mM} \mathrm{CaCl} 2$ and $4 \mu \mathrm{M}$ phospholipid vesicles. In some experiments CTI $(75 \mu \mathrm{g} / \mathrm{ml})$ was added to inhibit FXIla. Samples were analyzed with a field-emission scanning EM (FEl Quanta 200F, Hillsboro, OR) in 10 different areas of the clot and over at least 3 different samples.

\section{Fibrin pore-structure}

The average pore size of the fibrin clot (expressed as the Darcy constant Ks) was determined in permeation studies, where the flow rate of a buffer through a fibrin clot is measured. FXII-deficient plasma, to which 1, 10 or $100 \%$ FXII was added, was incubated with sulfatides $(1 \mu \mathrm{M})$, phospholipid vesicles $(4 \mu \mathrm{M})$ and $\mathrm{CaCl}_{2}(16 \mathrm{mM})$ for four hours in a moist chamber at room temperature. Permeation of Hepes-buffer ( $25 \mathrm{mM}$ Hepes $\mathrm{pH}=7.4,150 \mathrm{mM} \mathrm{NaCl}$ ) through the clot was quantified as described previously [25]. Briefly, using the flow rate and the following equation: $K s=(Q \times L \times \eta) /(T \times A \times P)$, the Darcy constant Ks in $\mathrm{cm}^{2}$ was calculated. $(\mathrm{Q}=$ volume of liquid $(\mathrm{ml}), \mathrm{L}=$ clot length $(\mathrm{cm}), \eta=$ viscosity (poise), $T=$ time (s), $A=$ cross-sectional area $\left(\mathrm{cm}^{2}\right)$, and $P=$ pressure drop (dyne/cm)).

\section{Clot viscoelasticity}

A magnetic microrheometer, previously described [26,27], was used to examine clot viscoelastic properties. The procedure of Evans et al [28] was used to extract the frequency dependent storage (G'; represents elastic energy stored 
during deformation and clot stiffness) and loss (G"; represents energy dissipated during deformation) modulus. The magnetic microrheometer operates by exerting a force on a $4.5 \mu \mathrm{m}$ superparamagnetic particle (Dynal, Oslo) using an external magnetic field generated by 4 electromagnets. The device was used in conjunction with an Olympus IX71 inverted optical microscope incorporating an ultra-long working distance objective (40x magnification) and CCD camera. Particle tracking, electromagnet control and image analysis was performed using custom written Labview 7.1 software (National Instruments). Purified fibrinogen $(1 \mathrm{mg} / \mathrm{ml})$ was mixed with $\mathrm{CaCl}_{2}(5.0$ $\mathrm{mM}$ ), TBS buffer (50 mM Tris, $150 \mathrm{mM} \mathrm{NaCl}, \mathrm{pH} 7.4$ ), magnetic particles suspended in distilled water and $\alpha-\mathrm{FXIla}$ at $0,31.25$ or $125 \mathrm{nM}$. Thrombin $(0.25$ $\mathrm{U} / \mathrm{ml}$ ) was added and the mixture was quickly transferred to a square glass capillary. For plasma clots, FXII-deficient plasma was diluted six times in TBS buffer and then mixed with $\mathrm{CaCl}_{2}(7.5 \mathrm{mM})$, magnetic particles and $\alpha-\mathrm{FXIla}$.

\section{FXII-FII double deficient plasma}

Congenital FXII-deficient plasma was batch wise immunodepleted for prothrombin. We coupled polyclonal sheep anti-human prothrombin and monoclonal anti-human prothrombin onto $\mathrm{CNBr}$-activated sepharose 4B. This sepharose was added to the plasma and rotated for 0.5 hour. The plasma was removed and the sepharose washed with high salt buffer $(25 \mathrm{mM} \mathrm{Hepes} \mathrm{pH} 7.4$; $1 \mathrm{M} \mathrm{NaCl}$ ), followed with low salt buffer (25 mM Hepes $\mathrm{pH} 7.4 ; 150 \mathrm{mM} \mathrm{NaCl}$ ). The procedure was repeated until prothrombin concentration did not change. Turbidity measurements showed that the process also removed part of the fibrinogen. Therefore, purified fibrinogen was added to the undiluted plasma to achieve a final concentration of $2 \mathrm{mg} / \mathrm{ml}$.

Prothrombin concentrations were quantified with the chromogenic substrate S2238 in triplicate in a 1:100 final dilution of plasma after complete activation with Ecarin the venom activator of Echis Carinatus (0.5 Unit/ml Ecarin).

\section{Thrombin generation}

The calibrated automated thrombogram method (Thrombinoscope, the Netherlands) was used to measure thrombin generation with several modifications. We added purified FXII to congenital FXII-deficient plasma (0 to $100 \%$ ) and to plasma deficient in FXII and prothrombin. Clotting was triggered with $0.4 \mu \mathrm{M}$ sulfatide and $4 \mu \mathrm{M}$ phospholipid vesicles and determination of thrombin generation was started upon addition of fluorogenic Z-Gly-Gly-ArgAMC substrate with $16 \mathrm{mM} \mathrm{CaCl}_{2}$ and was followed continuously in plasma (final concentration 67\%). 


\section{Chapter 2}

Surface plasmon resonance (SPR)

Binding of FXII, $\alpha-F X I l a$ and $\beta-F X I l a$ to fibrinogen and fibrin was analyzed with a Biacore 3000 (BIAcore, Stevenage, UK) as previously described [24,29] with the following modifications. Samples were analyzed in $20 \mathrm{mM}$ Hepes, $140 \mathrm{mM}$ $\mathrm{NaCl}$, and $2.5 \mathrm{mM} \mathrm{CaCl}_{2}$ with $0.05 \% \mathrm{P}-20, \mathrm{pH} 7.4$, and the experiments were performed at $25^{\circ} \mathrm{C}$. Fibrinogen was coated to a carboxymethyldextra-coated biosensor chip (CM5) by amine coupling, to yield approximately 1000 response units. Immobilized fibrinogen was converted to fibrin by running $5 \mathrm{U} / \mathrm{ml}$ of thrombin at $2 \mu \mathrm{l} /$ minute for 20 minutes. Thrombin was removed by injecting $1 \mathrm{M}$ $\mathrm{NaCl}$.

FXII, $\alpha$-FXlla or $\beta$-FXIla were dialyzed overnight in $20 \mathrm{mM}$ Hepes, $140 \mathrm{mM}$ $\mathrm{NaCl}$, and $2.5 \mathrm{mM} \mathrm{CaCl}_{2}$. Protein concentrations were measured by nanodrop 3.1.0 (Thermo Scientific, Wilmington, DE). Extinction coefficients $(1 \%, 280 \mathrm{~nm}$ ) of 14.1 and 15.2 were used for calculation of the concentration for FXII, $\alpha$-FXIla and $\beta$-FXIla respectively [30]. FXII, $\alpha$-FXIla or $\beta$-FXIla preparations were injected for 3 minutes at $30 \mu \mathrm{l} /$ minute, and the dissociation was monitored for 3 minutes. The surface was regenerated with $3 \mathrm{M} \mathrm{NaCl}, \mathrm{pH} 7.4$ at $30 \mu \mathrm{l} /$ minute, followed by buffer $(60 \mu \mathrm{l})$ and re-equilibration with running buffer for 5 minutes. Benzamidine $(5 \mathrm{mM})$ was included during dialysis and in the running buffer to prevent FXII activation. Control experiments with gel electrophoresis and amidolytic activity with S2302 showed negligible FXII activity after dialysis (data not shown).

\section{Immunoprecipitation}

FXII was immunoprecipitated from normal pooled plasma with a polyclonal antihuman FXII antibody. The immunoprecipitate was isolated from plasma by protein G-Sepharose 4 Fast Flow. The sepharose was intensively washed and the extracted protein was subjected to SDS gel electrophoresis. The sample was run on two separate $4-15 \%$ acrylamide gradient gels (Bio-rad) with Tris/glycine buffer. Afterwards the proteins were analyzed by western blotting and transferred to sheets of Immobilon-P transfer membrane and detected with 1) a polyclonal goat anti-human FXII antibody and 2) a polyclonal sheep antihuman fibrinogen antibody.

\section{Immunostaining}

Three human thrombi were collected during carotid endarterectomies. The specimens were obtained from the Maastricht Pathology Tissue Collection. Collection, storage, and use of tissue and patient data were performed in agreement with the Code for Proper Secondary Use of Human Tissue in the 
Netherlands (http://www.fmwv.nl). Paraffin sections $(4 \quad \mu m)$ were immunohistochemically stained for both fibrin(ogen) and FXII(a) as described [31].

\section{Statistical analysis}

Data are expressed as mean and range or standard error of the mean (SEM) as indicated. Statistical analyses were performed with GraphPad Prism 5 using oneway analysis of variance (ANOVA), Bonferroni for post hoc comparison, or $t$ test (GraphPad Software) when appropriate, and $P$ values less than 0.05 were considered statistically significant.

\section{Results}

\section{FXIla and fibrin structure in purified systems}

At a fixed thrombin concentration, purified $\alpha-F X I l a$ increased the lag time to fibrin formation and decreased maximal turbidity (Figure 2.1A). Since thrombin is an important determinant of fibrin formation and clot architecture, we confirmed that these effects of a-FXlla on clot formation and structure occurs at different thrombin concentrations (Figure 2.1B-C). The effects were strongest at the lower end of the thrombin concentrations tested. Next, fibrin clots were visualized by scanning EM in the presence of $\alpha-F X I l a$ at a fixed thrombin concentration $(2.5 \mathrm{nM})$. Figure 2.1F shows a dose-dependent increase in fibrin structure compactness, with thinner fibers and smaller pores at higher $\alpha$-FXIla levels compared to control clots. These findings agree with the lower maximum turbidity observed in the presence of $\alpha-F X I l a$, since lower turbidity is correlated with thinner fibrin fibers [32]. The presence of FXII-zymogen or $\beta$-FXIla did not influence fibrin clot structure by turbidimetric assays or microscopy (data not shown). Inhibition of $\alpha$-FXIla with PPACK or CTI reversed the effect on fibrin structure, indicating that the proteolytic activity of $\alpha-F X I l a$ is necessary to change fibrin structure (Figure 2.1 D-F). 

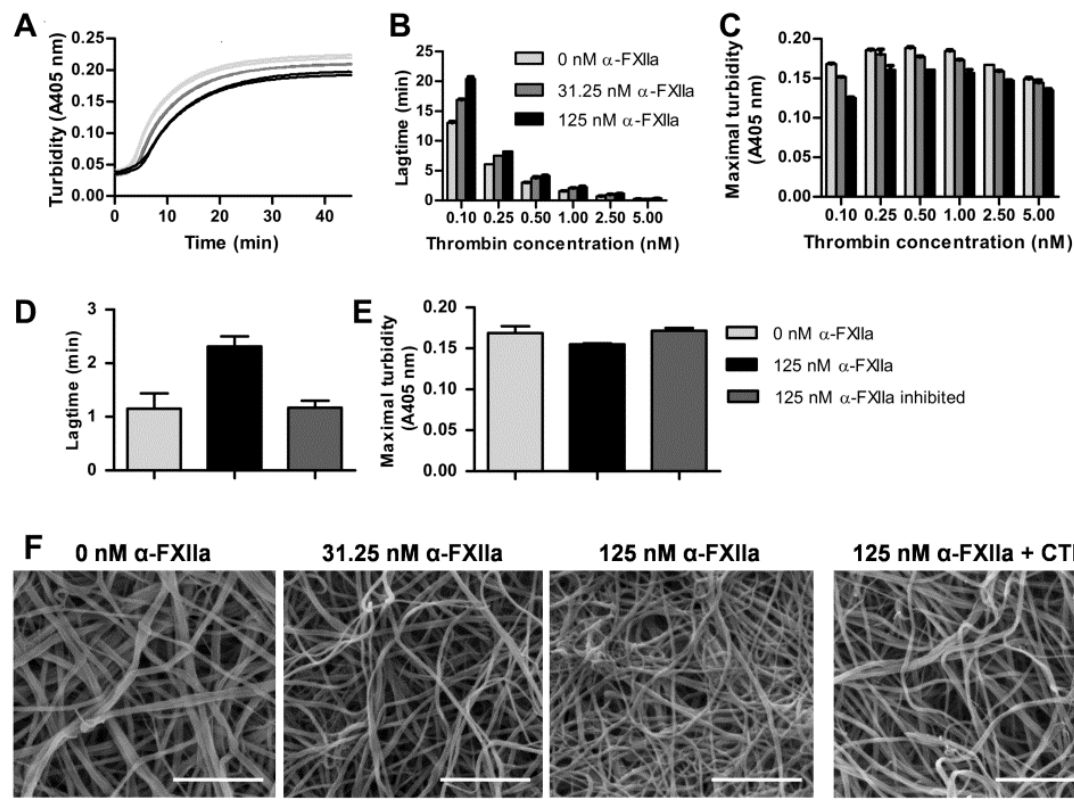

$125 \mathrm{nM}$ a-FXIla + CTI

Figure 2.1. Effect of $\alpha-F X I l a$ on fibrin polymerization and fibrin structure.

$(A-E)$ Human fibrinogen $(1 \mathrm{mg} / \mathrm{ml})$ was incubated with $\alpha$-FXIla $(0-125 \mathrm{nM})$ in Hepesbuffer $(25 \mathrm{mM}$ Hepes, $150 \mathrm{mM} \mathrm{NaCl}, \mathrm{pH}=7.4)$. for 10 minutes at $37^{\circ} \mathrm{C}$ before clotting was initiated with $\mathrm{CaCl}_{2}(5 \mathrm{mM})$ and thrombin $(0.1-5 \mathrm{nM})$. Turbidity was monitored every $15 \mathrm{~s}$ at $405 \mathrm{~nm}$ at $37^{\circ} \mathrm{C}$. (A) Time course of fibrin clot formation with three a-FXIla concentrations (0, 31.25 and $125 \mathrm{nM}$; each in duplicate) initiated with $0.5 \mathrm{nM}$ thrombin. (B) Lag time of fibrin formation and (C) maximal turbidity as a function of thrombin concentration. (D-E) To inhibit $\alpha-F X I l a$, PPACK (1000 nM) was incubated with $\alpha-F X I l a$ and removed via dialysis in Hepes-buffer $(25 \mathrm{mM}$ Hepes, $150 \mathrm{mM} \mathrm{NaCl}, 1 \mathrm{mg} / \mathrm{ml} \mathrm{BSA}$, $\mathrm{pH}=7.4$ ). Clotting was initiated with $1 \mathrm{nM}$ thrombin. (D) Lag time of fibrin formation, $(\mathrm{E})$ maximal turbidity. Figures B-E represent the mean \pm range of two separate experiments. (F) Representative scanning electron microscopy images of clots $(n=6)$ prepared by incubating fibrinogen $(1 \mathrm{mg} / \mathrm{ml})$ with $\alpha-F X I l a ~(0-125 \mathrm{nM})$, thrombin $(2.5 \mathrm{nM})$ and $\mathrm{CaCl}_{2}$ (5 mM) in Hepes-buffer ( $20 \mathrm{mM}$ Hepes, $150 \mathrm{mM} \mathrm{NaCl}, \mathrm{pH}=7.4$ ) for 2 hours at room temperature. To inhibit $\alpha-\mathrm{FXIla}$, corn trypsin inhibitor (CTI; $75 \mu \mathrm{g} / \mathrm{ml})$ was added to 125 $\mathrm{nM} \alpha-\mathrm{FXIla}$. Scale bars $=1 \mu \mathrm{m}$

\section{FXIla and clot architecture in plasma}

We next investigated the impact of FXIla on fibrin clot structure in plasma. Turbidity showed a dose-dependent decrease in lag time and maximum turbidity with increasing FXII concentration (Figure 2.2A). No clotting was observed without the addition of FXII to FXII-deficient plasma within 60 minutes. The lag time decreased with increasing levels of FXII presumably due to increased thrombin generation via FXII activation. To view the corresponding fibrin structure we performed confocal microscopy experiments. Figure 2.2B-C 
shows a dose dependent increase in fiber density with increasing levels of FXII $(p<0.05)$. Moreover, scanning EM in plasma at higher FXII concentrations revealed a denser structure with thinner fibers (data not shown) and the permeation constant (Darcy constant Ks), which is a direct measure of the poresize, decreased at higher levels of FXII indicating smaller pore-size. The Ks for clots produced with $1 \mu \mathrm{M}$ sulfatides and 1,10 or $100 \%$ FXII in FXII-deficient plasma was $33.2,26.4$, and $19.3 \times 10^{-9} \mathrm{~cm}^{2}$ respectively (supplemental Table S2.1). Furthermore, turbidimetric lysis assays showed that the clot lysis time in plasma increased and the maximum rate of lysis decreased in a FXII concentration dependent manner (supplemental Figure S2.1).
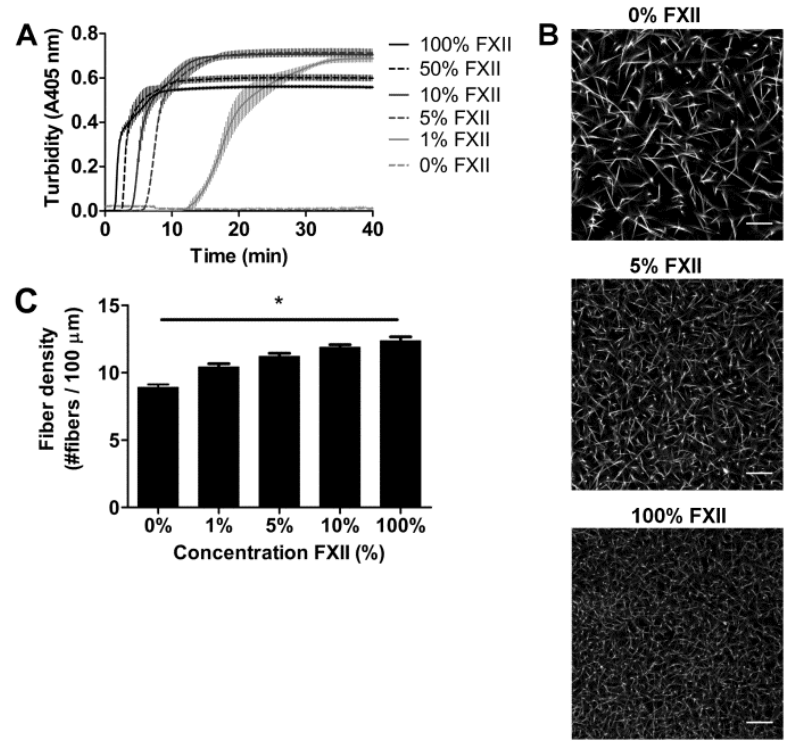

Figure 2.2. Effect of FXII-concentration on fibrin structure in plasma.

(A) FXII-deficient plasma was reconstituted with purified FXII and clotting was initiated via contact activation with sulfatides, in the presence of phospholipid vesicles and $\mathrm{CaCl}_{2}$. Turbidity was monitored every $15 \mathrm{~s}$ at $405 \mathrm{~nm}$ at $37^{\circ} \mathrm{C}$. Final concentrations were $76 \%$ plasma, variable FXII concentrations ( $0 \%$ - $100 \%$ of normal plasma concentration), $4 \mu \mathrm{M}$ sulfatides, $4 \mu \mathrm{M}$ phospholipid vesicles and $16 \mathrm{mM} \mathrm{CaCl}_{2}$. Figure shows the mean \pm range of three measurements. (B) Representative figures of immunofluorescent staining of fibrin clots. FXII-deficient plasma was reconstituted with purified FXII. AlexaFluor488 fibrinogen was added and clotting was initiated with sulfatides, phospholipid vesicles and $\mathrm{CaCl}_{2}$. Final concentrations were $25 \%$ plasma, $5 \%$ AlexaFluor488 fibrinogen of the total fibrinogen concentration, a range of FXII $(0 \%$ $100 \%$ of normal plasma concentration), $0.4 \mu \mathrm{M}$ sulfatides, $4 \mu \mathrm{M}$ phospholipid vesicles, $5 \mathrm{mM} \mathrm{CaCl}_{2}$, and $25 \mathrm{mM}$ Hepes ( $\left.\mathrm{pH}=7.4\right), 150 \mathrm{mM} \mathrm{NaCl}$. (C) Fiber density was calculated from the data shown in panel B. Per condition, two separate clots were made, images were taken in different areas of the clot and fiber density was determined in five images by counting the number of fibers that crossed a line of $100 \mu \mathrm{m}$. Bars represent mean \pm SEM with statistical significance noted as * $p<0.05)$. Scale bars $=25 \mu \mathrm{m}$ 


\section{Chapter 2}

\section{Viscoelastic properties}

We used magnetic tweezers equipment to probe the effect of $\alpha-F X$ Ila on clot viscoelastic properties. We found a non-linear increase in clot stiffness ( $\left.G^{\prime}\right)$ in the presence of $\alpha-F X I l a$. Stiffness of clots made from purified fibrinogen increased nearly two-fold with $31 \mathrm{nM}$ and 1,3-fold with $125 \mathrm{nM}$ a-FXIla (Table 2.1). The stiffness of plasma clots increased 1.7-fold and 1.2-fold with $31 \mathrm{nM}$ and $125 \mathrm{nM} \alpha$-FXlla respectively. The non-linearity of these data suggest that an optimal degree of fiber branching and thickness occurs, which leads to maximal stiffness. At higher $\alpha-F X l l a$ concentration, fibers may become too thin to support maximal stiffness. The loss modulus (G") and viscous fraction (G"'G') of the clot did not change significantly with FXIla.

Table 2.1. Effects of FXIla on viscoelastic properties of fibrin clots produced with purified fibrinogen and plasma

\begin{tabular}{|c|c|c|c|c|c|c|}
\hline \multirow[b]{2}{*}{ [a-FXIla] (nM) } & \multicolumn{3}{|c|}{ Plasma } & \multicolumn{3}{|c|}{ Purified fibrinogen } \\
\hline & 0 & 31 & 125 & 0 & 31 & 125 \\
\hline $\mathbf{G}^{\prime}(\mathrm{Pa})$ & $2.89 \pm 0.07$ & $4.9 \pm 0.2$ & $3.47 \pm 0.05$ & $1.95 \pm 0.05$ & $3.84 \pm 0.08$ & $2.52 \pm 0.04$ \\
\hline G”' (map) & $0.8 \pm 0.1$ & $1.1 \pm 0.2$ & $1.2 \pm 0.1$ & $0.20 \pm 0.02$ & $0.75 \pm 0.02$ & $0.32 \pm 0.03$ \\
\hline G'/G' $\left(10^{-3}\right)$ & $0.28 \pm 0.02$ & $0.22 \pm 0.04$ & $0.36 \pm 0.02$ & $0.10 \pm 0.01$ & $0.20 \pm 0.07$ & $0.36 \pm 0.03$ \\
\hline
\end{tabular}

G': storage modulus or clot stiffness. G": loss modulus. G"/G': viscous fraction of the clot

\section{Thrombin-independent effects}

\section{FXII and prothrombin deficient plasma}

As thrombin influences fibrin clot structure [33], we aimed to investigate if (at least part of) the effects of FXIla on fibrin structure in plasma were independent of thrombin generation. First, we compared thrombin generation in FXIIdeficient plasma to which purified FXII (up to 100\%) was added with that in the absence of FXII. Fully reconstituted FXII-deficient plasma showed a 38-fold increase in thrombin peak height as compared to the non-reconstituted plasma (295 nM Ila vs. $7.7 \mathrm{nM}$ Ila; supplemental Figure S2.2A; supplemental Table S2.2). To test if FXII also contributes to a fibrin structure change independent of the effect on thrombin formation, the prothrombin in the FXIIdeficient plasma was removed by immunodepletion to yield plasma deficient in both FXII and prothrombin. The prothrombin concentration dropped to $3.2 \%$ as measured after activation of prothrombin with Ecarin and quantification with the chromogenic substrate S-2238. Using this double-deficient plasma we analyzed the effect of FXII $(0-100 \%)$ on fibrin structure. Sulfatides were added to initiate contact activation and fibrin formation was initiated after 10 minutes by addition of thrombin $(0.625 \mathrm{nM})$, phospholipid vesicles and $\mathrm{CaCl}_{2}$. Confocal microscopy 
showed a denser fibrin structure at higher FXII levels (Figure 2.3A-B), despite a marginal increase in thrombin peak height from $13.3 \mathrm{nM}$ in the absence of FXII to $16.2 \mathrm{nM}$ with $100 \%$ FXII (supplemental Figure S2.2B; supplemental Table S2.2).

A

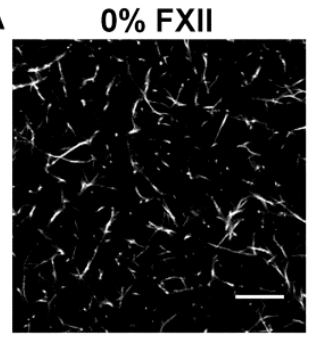

C

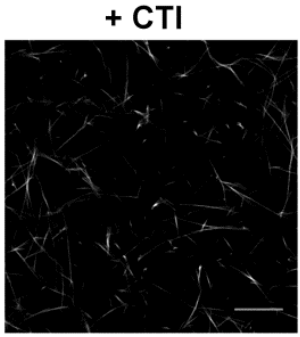

$100 \%$ FXII

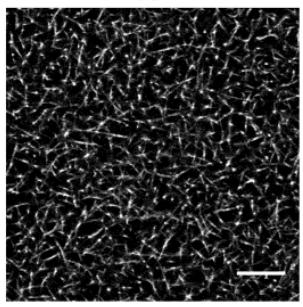

$+30 \mathrm{nM}$ a-FXIIa

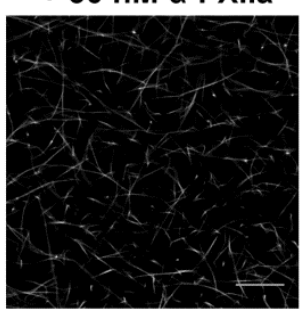

B

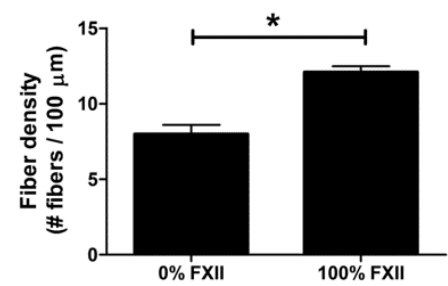

D

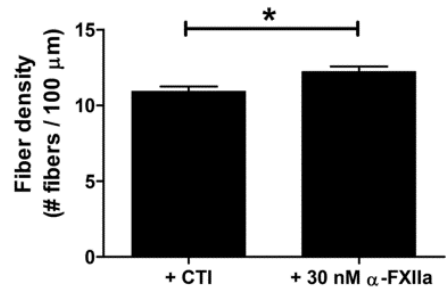

Figure 2.3. Effect of FXlla on fibrin fiber density, independent from additional thrombin formation.

(A-B) Plasma deficient in FXII and prothrombin was reconstituted with FXII. Sulfatides and AlexaFluor488 fibrinogen were added and clotting was initiated with $0.625 \mathrm{nM}$ thrombin, in the presence of phospholipid vesicles and $\mathrm{CaCl}_{2}$. Final concentrations were $25 \%$ plasma, $5 \%$ AlexaFluor488 fibrinogen of the total fibrinogen concentration, FXII (0\% or $100 \%$ of normal plasma-concentration), $0.4 \mu \mathrm{M}$ sulfatides, $4 \mu \mathrm{M}$ phospholipid vesicles, $5 \mathrm{mM} \mathrm{CaCl}_{2}$, in Hepes-buffer (25 mM Hepes, $150 \mathrm{mM} \mathrm{NaCl}, \mathrm{pH}=7.4$ ). Per condition, two separate clots were made, pictures were taken in different areas of the clot.

(C-D) Prothrombin-deficient plasma, in the presence of hirudin, was incubated with the FXIla-inhibitor corn trypsin inhibitor (CTI) or with a-FXIla. AlexaFluor488 fibrinogen was added to the plasma and clotting was initiated by the addition of ancrod and $\mathrm{CaCl}_{2}$. Final concentrations were $25 \%$ plasma, $30 \mathrm{nM}$ hirudin, $75 \mu \mathrm{g} / \mathrm{ml} \mathrm{CTI}, 30 \mathrm{nM}$ a-FXIla, $5 \%$ AlexaFluor488 fibrinogen of the total fibrinogen concentration, $0.1 \mathrm{U} / \mathrm{ml}$ ancrod, $5 \mathrm{mM} \mathrm{CaCl}_{2}$, in Hepes-buffer (25 mM Hepes, $150 \mathrm{mM} \mathrm{NaCl}, \mathrm{pH}=7.4$ ). (B and D) Fiber density was calculated from the data shown in the corresponding panel. Per condition, two separate clots were made, pictures were taken in different areas of the clot and fiber density was determined in five pictures by counting the number of fibers that crossed a line of $100 \mu \mathrm{m}$. Bars represent mean \pm SEM with statistical significance noted as $\left.{ }^{*} p<0.05\right)$. Scale bars $=25 \mu \mathrm{m}$ 


\section{Chapter 2}

Fibrin formation by ancrod

To further investigate the direct effect of FXIla on clot structure in plasma, we clotted prothrombin depleted plasma (prothrombin $<1 \%$ ) with the fibrin snake venom activator ancrod in the presence of hirudin, a thrombin inhibitor. We added either $\alpha$-FXIla or CTI (a potent inhibitor of FXIla) to the plasma. Confocal microscopy of these clots showed an increase in the fiber density in the presence of $\alpha$-FXIla compared to inhibitor (Figure 2.3C-D).

\section{FXII(a) binding to fibrin(ogen)}

In view of the homology between FXII and tPA, we investigated whether FXII, $\alpha$ FXIla and $\beta-F X I l a$ bind to fibrinogen and fibrin by SPR $[24,29]$. Figure 2.4 shows binding of FXII, $\alpha-F X I l a$ and $\beta-F X I l a$ to fibrinogen and fibrin at four protein concentrations. Supplemental Figures S2.3-S2.4 show all tested concentrations, including separate global kd and ka fittings used for calculation of kinetic constants. FXII and $\alpha$-FXIla bound with similar affinity to fibrinogen and fibrin (Figure 2.4; Table 2.2). Overall binding response was higher for FXII when compared with similar concentrations of $\alpha-F X I l a$. The affinity of $\beta$-FXIla to fibrinogen and fibrin was 20-40 fold lower (Table 2.2) compared to FXII or $\alpha$ FXIla, and a significant binding response was only observed at $300 \mathrm{nM} \beta$-FXIla and higher concentrations (Figure 2.4, supplemental Figure S2.4). These data indicate the presence of a high-affinity binding site on the heavy chain of FXII and $\alpha$-FXIla for fibrinogen and fibrin.

Immunoprecipitation of FXII from normal pooled plasma, showed that fibrinogen co-precipitates with FXII. Blotting of the precipitate showed positive staining for FXII and for fibrinogen (Figure 2.4G-H).

Table 2.2. Surface plasmon resonance analyses of FXII(a) binding to fibrin(ogen)

\begin{tabular}{lccc}
\hline & $\begin{array}{c}\mathbf{k d} \\
\text { (off-rate, } \mathbf{1 / s} \text { ) }\end{array}$ & $\begin{array}{c}\mathbf{k a} \\
\text { (on-rate, 1/Ms) }\end{array}$ & $\begin{array}{c}\mathbf{K}_{\mathrm{D}} \\
\text { (dissociation constant, M) }\end{array}$ \\
\hline FXII to fibrinogen & $2.9 \times 10^{-3}$ & $9.8 \times 10^{5}$ & $3.0 \times 10^{-9}$ \\
FXII to fibrin & $2.9 \times 10^{-3}$ & $11.8 \times 10^{5}$ & $2.5 \times 10^{-9}$ \\
$\boldsymbol{\alpha}$-FXIla to fibrinogen & $1.8 \times 10^{-3}$ & $4.3 \times 10^{5}$ & $4.1 \times 10^{-9}$ \\
$\boldsymbol{\alpha}-$ FXIla to fibrin & $1.8 \times 10^{-3}$ & $3.9 \times 10^{5}$ & $4.6 \times 10^{-9}$ \\
$\boldsymbol{\beta}$-FXIla to fibrinogen & $8.2 \times 10^{-4}$ & $8.7 \times 10^{3}$ & $9.4 \times 10^{-8}$ \\
$\boldsymbol{\beta}$-FXIla to fibrin & $8.7 \times 10^{-4}$ & $9.2 \times 10^{3}$ & $9.4 \times 10^{-8}$ \\
\hline
\end{tabular}



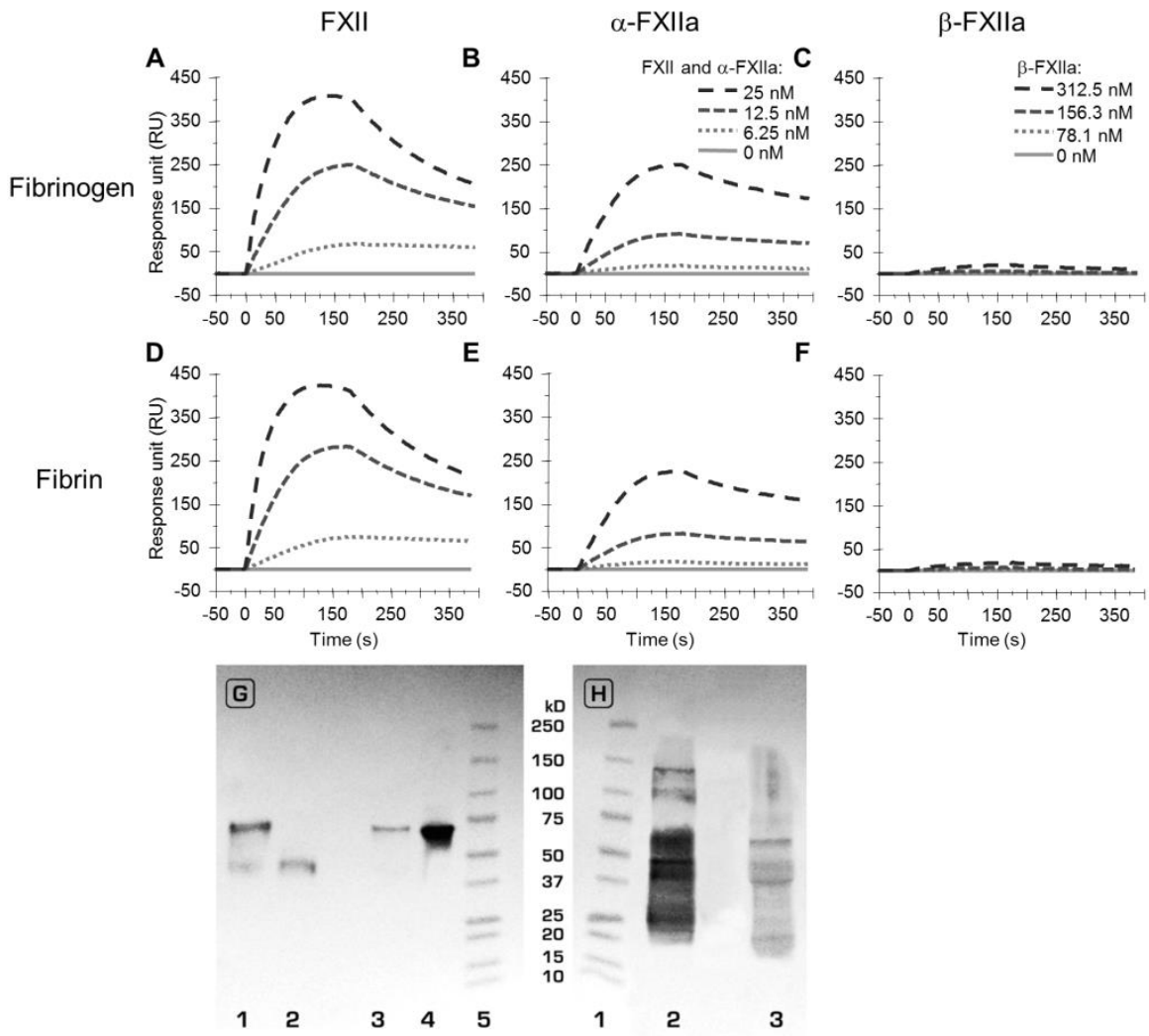

\section{Figure 2.4. Binding of FXII(a) to fibrin(ogen) analyzed by surface plasmon} resonance.

Panels A and B show the binding to fibrinogen of (from top to bottom) 25, 12.5, 6.25 and $0 \mathrm{nM} F \mathrm{FXI}$ and $\alpha$-FXIla respectively. Panel C shows the (negligible) binding of $\beta$-FXIla to fibrinogen at concentrations of (from top to bottom) 312.5, 156.3, 78.1 and $0 \mathrm{nM}$. Bottom

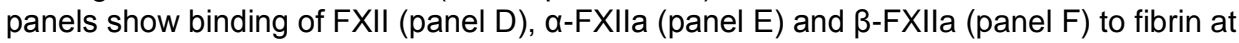
identical concentrations as in panels A-C respectively. For reasons of clarity, not all tested concentrations are shown in this figure. Supplemental Figures S2.3-2.4 show the responses for all tested concentrations, including the ka and kd fitting which were used to determine the $\mathrm{K}_{\mathrm{D}}$-values as presented in Table 2.2. The graphs represent the mean of three experiments. Panels $\mathrm{G}$ and $\mathrm{H}$ show Western blots after immunoprecipitation of FXII from normal pooled plasma. In panel G, the blot was stained for FXII with polyclonal anti-human FXII and in panel $\mathrm{H}$ the blot was stained for fibrinogen with polyclonal antihuman fibrinogen. (G) Lane $1(0.05 \mu \mathrm{g}$ non-reduced FXIla) and lane $2(0.05 \mu \mathrm{g}$ reduced FXIla) are controls, lane 3 is reduced immunoprecipitate, lane 4 is non-reduced immunoprecipitate and lane 5 is a molecular weight marker. $(\mathrm{H})$ Lane 1 is a molecular weight marker, lane $2(0.25 \mu \mathrm{g}$ reduced fibrinogen) is control and lane 3 is reduced immunoprecipitate. The blots show the presence of zymogen FXII ( $80 \mathrm{kD}$; panel G) and the A $\alpha$-chain $(66 \mathrm{kD}), \mathrm{B} \beta$-chain $(52 \mathrm{kD})$ and $\mathrm{\gamma}$-chain $(46 \mathrm{kD}$ ) of fibrinogen (panel $\mathrm{H})$. 
FXII and fibrin(ogen) in carotid thrombi

We next aimed to find evidence for a role of FXII in fibrin structure in vivo. For this we obtained thrombi from the human carotid artery, removed during carotid endarterectomy and immunostained these samples for fibrin(ogen) and FXII(a). We observed that carotid artery thrombi stained positive for both FXII(a) and fibrin(ogen) and that the proteins co-localized in the thrombi. The areas that stained positive for FXII(a) coincided with the areas of the thrombus that showed denser fibrin architecture (Figure 2.5).
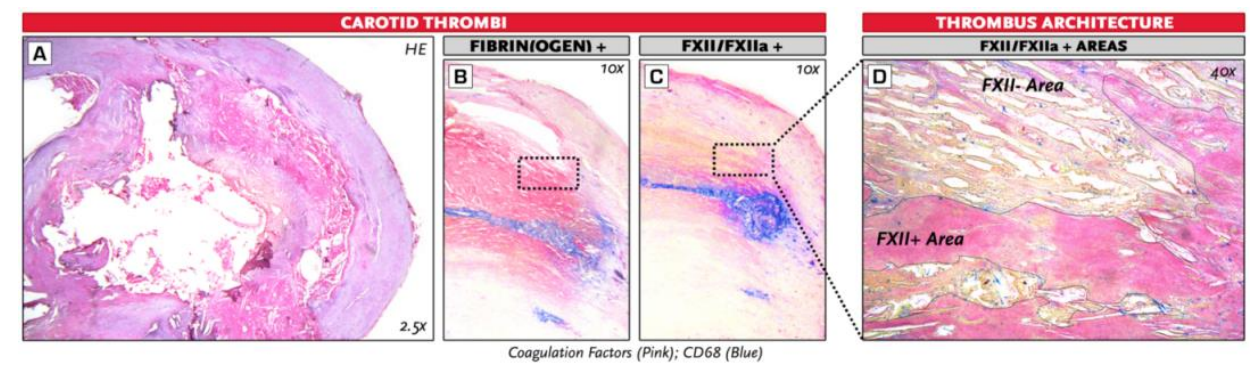

Figure 2.5. Staining of FXII(a) and fibrin(ogen) in human carotid thrombi.

Representative images of three human carotid thrombi. (A) Overall figure: hematoxylin and eosin (HE) staining, (B) immunohistochemical double staining for fibrin(ogen) and CD68 (staining for monocytes/macrophages), and (C and D) immunohistochemical double staining for FXII(a) and CD68 of a human carotid thrombus. Magnification 2.5X for panel A, 10X for panel $B$ and $C$ and $40 X$ for panel $D$. In panel D the FXII/FXIlapositive and negative areas are outlined.

\section{Discussion}

The structure of a fibrin clot is an emerging determinant of thrombotic events [34-36]. Ex vivo clots of patients with premature coronary artery disease are stiffer, form a denser fibrin network and are more difficult to lyse [7]. Our experiments show that FXIla changes fibrin clot structure in a dose-dependent manner. The effects of FXIla on fibrin structure are consistent with those observed in patients with thrombosis. Using a combination of deficient plasmas and purified proteins we show that the effects of FXIla on fibrin structure are partly independent of the role of FXIla in thrombin generation. We find that binding of FXII(a) to fibrinogen and fibrin is of high affinity and involves the heavy chain of FXII(a), providing a potential mechanism for the observed direct influence of FXIla on fibrin structure. Finally, evidence is provided for the colocalization of FXII(a) with areas of dense fibrin(ogen) deposition in human thrombi obtained from patients with carotid artery disease. 
Clotting of purified fibrinogen in the presence of $\alpha$-FXIla led to the formation of fibrin with a denser structure. Experiments in congenital FXII-deficient plasma, to which purified FXII was added, also showed a denser clot structure. This FXIla-dependent change in fibrin structure was correlated with decreased fibrinolysis [37]. Since the level of thrombin generation in the experiments with FXII-deficient plasma was directly influenced by the FXII-concentration, we immunodepleted prothrombin from this plasma. Using this double-deficient plasma we also observed a denser clot structure at $100 \%$ added FXII compared to no addition of FXII. However, this plasma was not entirely prothrombin free, with approximately $3 \%$ residual protein detected. To investigate fibrin formation completely independent of intrinsic pathway driven thrombin generation, we added hirudin to a commercial prothrombin depleted plasma to avoid any thrombin activity and induced fibrin formation with ancrod, a snake venom enzyme. We compared the structure of the fibrin clots formed in the presence of FXIla with those formed in the presence of CTI to inhibit FXIlla formation and/or any FXIla that might have been formed. We observed significantly denser clot structures in the presence of $\alpha-F X I l a$, confirming that FXIla influenced clot structure independent of its effects on thrombin.

The contribution of FXII to in vivo thrombin formation has long been debated. Contact activation can be assayed effectively using in vitro coagulation tests, but patients deficient in FXII do not show a bleeding tendency [16]. Clinical studies point to a contribution of FXII in arterial thrombosis in humans, but the data are ambiguous [20,38-42]. Both low and high levels of FXII, FXIla or FXIlaC1-esterase inhibitor have been associated with an increased risk of thrombosis. Some of the inconsistencies in clinical studies may be related to differences in assay methodologies since different aspects of the contact pathway were determined. In addition, true differences in the effects of FXII(a) related to the populations (young women versus elderly individuals) and vascular bed specific factors (coronary or cerebral thrombosis) may be involved.

Surface plasmon resonance binding experiments showed that purified FXII and $\alpha-F X l l a$ were able to bind to purified fibrin and fibrinogen with similar nanomolar affinity. This high binding affinity suggests that FXII and fibrinogen circulate as a complex in plasma, which was confirmed by western blots and positive staining for fibrinogen after immunoprecipitation of FXII from plasma. Our data indicate that the heavy chain of FXII(a) is involved in this interaction but the location of the binding site(s) on fibrin(ogen) is unknown. One candidate could be the $\mathrm{COOH}$-terminal two-thirds of the Aa-chains of the fibrinogen molecule, also called aC-region, which is an important determinant of fibrin structure [43]. The 
aC-region is important for lateral aggregation during fibrin polymerization and determines its susceptibility to fibrinolysis [44]. Regulators of fibrinolysis, such as IPA and plasminogen bind to this region and FXII contains several domains which are homologous to tPA [45,46]. However, the binding site for IPA and plasminogen are concealed in fibrinogen and are only exposed upon fibrin formation. Therefore, the binding affinity of TPA and plasminogen for fibrin is higher than for fibrinogen [24,29]. FXII(a) on the other hand bound to a site which is exposed in both fibrin and fibrinogen. Turbidity assays with purified proteins showed a delay in lateral aggregation in the presence of $\alpha-F X I l a$ as represented by an increase in lag time. The $\mathrm{aC}$-region of fibrinogen is important for lateral aggregation and binding of $\alpha-F X I l a$ to this part of the molecule might explain the delay. Furthermore, within the aC-region there is a cluster of negatively charged amino acids (E448-D449, D452) [47] which could serve as a binding site for FXII and $\alpha-F X I l a$. Further studies will be required to determine the fibrinogen binding site for FXII(a).

FXII and $\alpha$-FXlla have the same molecular weight $(80 \mathrm{kDa})$ because activation results from a single cleavage that allows the disulphide bonded heavy and light chains to remain associated. $\beta$-FXIla $(28 \mathrm{kDa})$ is formed following an additional cleavage of $\alpha-F X I l a$ by kallikrein and contains the active site, but has lost the heavy chain. $\beta$-FXIla exhibited a 20-40 times lower affinity for fibrin(ogen) than FXII or $\alpha$-FXIla. This implies that at least one high affinity binding site for fibrin(ogen) is located on the heavy chain. The heavy chain of FXII(a) contains several binding sites for negatively charged surfaces, such as in the Fibronectin Type I domain [48]. Despite the similar binding profiles to fibrin(ogen), changes in fibrin clot structure were only observed with a-FXIla. This implies that both binding and enzymatic activity were involved in $\alpha-F X I l a$ associated changes in fibrin clot structure. Our findings that CTI and PPACK reversed the effects of FXIla on fibrin structure appear to be in agreement with the requirement of proteolytic activity. Another possibility is that conformational changes of FXII during activation may lead to the observed effects on fibrin clot structure. CTI and PPACK are known to inhibit the proteolytic activity of FXIla, however, this does not exclude that they can affect the conformation of FXIla. Future studies will need to be performed to investigate this further. 


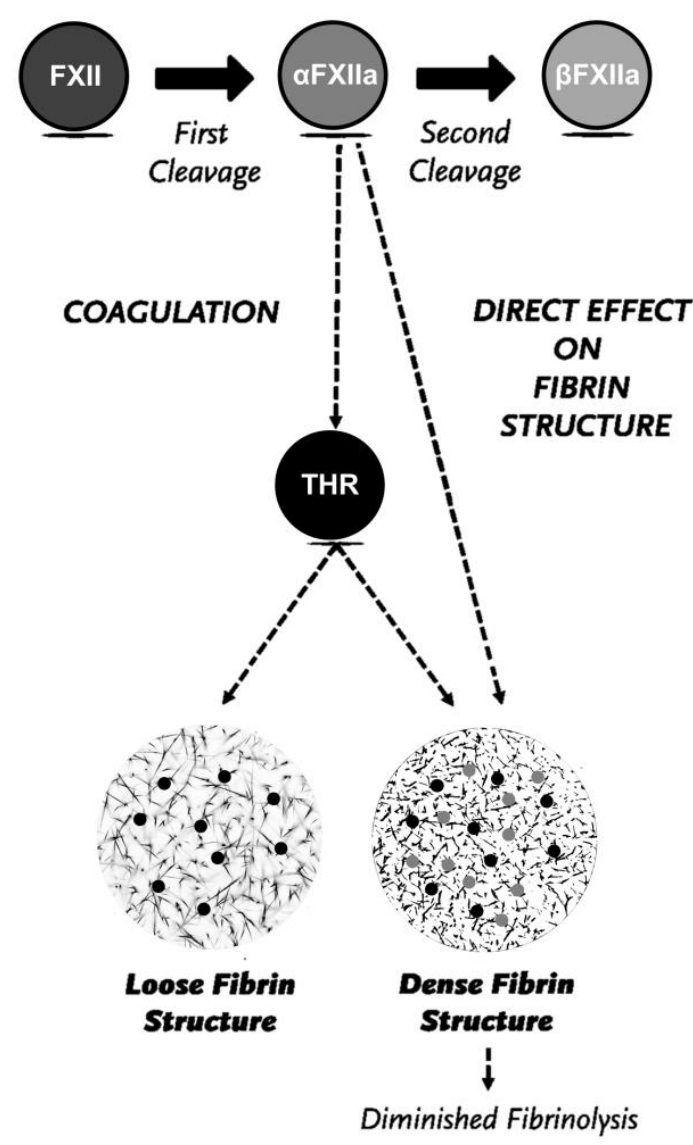

Figure 2.6. Schematic representation of the new insights in the role of FXIla in fibrin clot formation.

Activation of FXII leads to the formation of two forms of activated FXII: $\alpha$-FXIlla (twochain molecule composed of a heavy chain and a light chain held together by a disulfide bond, the same molecular weight as FXII) and further proteolytic cleavage results in $\beta$ FXIla (loss of the heavy chain). $\alpha$-FXIla can initiate thrombin formation via the intrinsic pathway of coagulation by activating FXI. FXII and $\alpha-F X I l a$ can both bind with the same affinity to fibrinogen and fibrin and binding of $\alpha-F X l l a$ leads to a direct effect on fibrin structure.

Once triggered, the coagulation pathway interacts to generate a burst of thrombin which will convert fibrinogen to fibrin. Our findings indicate the need for a revision of the coagulation pathway with a new role for $\alpha$-FXlla in fibrin formation, additional to its role in thrombin generation (Figure 2.6). After the first cleavage, FXII is converted to $\alpha-F X I l a$. $\alpha-F X I l a$ promotes thrombin formation via the intrinsic pathway of coagulation but also directly increases the fiber density 


\section{Chapter 2}

within the clot and makes it resistant to fibrinolysis. After a second cleavage, $\beta$ FXIla is formed, which does not influence the fibrin structure. Hence the ratio of $\alpha$ - over $\beta$-FXIla can be expected to be an important determinant of the structure and function of the fibrin clot.

We found in vivo evidence for the role of FXIla in fibrin structure and function, since in human carotid thrombi, FXII(a) co-localized with fibrin(ogen), and denser fibrin(ogen) depositions were observed in FXII(a) positive areas. Therefore, higher levels of FXII(a) may contribute to the denser fibrin(ogen) structures which stabilize the thrombus. Interestingly, previous studies using animal models found that FXIla was associated with increased thrombus formation through an interaction with platelets, which provide a surface for FXII activation $[12,49]$. Our findings suggest that the role of FXIla is not limited to platelet-driven thrombus formation, but that effects on fibrin clot structure and function play an additional role in thrombus stabilization.

Factor XII was discovered as a coagulation protein, but many functions of FXIla have been discovered: e.g. complement activation [50], fibrinolysis [11], angiogenesis [51,52] and bradykinin formation [11]. It has been reported that FXIla shows profibrinolytic activity via direct activation of plasminogen. However, FXIla is a very poor enzyme in activating plasminogen compared to tPA and will be overruled when IPA is present [11]. When we added IPA to the system we observed that the clot lysis time increased dose-dependently with the $\alpha-F X I I$ concentration. Therefore, in these experiments the additional thrombin formation and direct effects of FXIla on clot structure appeared to be more important than any profibrinolytic effect that FXIla may have through plasminogen to plasmin conversion.

Our study provides evidence for a distinct contribution of FXII in a concentration dependent manner to pathologic thrombus formation via the formation of compact fibrin structures with increased fiber density and reduced pore-size. In vivo, many components participate in the formation of a thrombus. Disruption of the vessel wall or atherosclerotic plaque exposes the subendothelium which leads to platelet activation and thrombin formation. The platelets form aggregates which are stabilized by fibrin fibers. FXII and $\alpha$-FXIla bind to fibrinogen and fibrin, through the $\mathrm{N}$-terminal heavy chain of FXII. The direct effects of FXlla on fibrin structure and function are synergistic with its indirect effects on fibrin formation through enhanced thrombin generation, contributing a novel mechanism that consolidates the fibrin clot. Collagen, within the subendothelium, amyloid deposits and polyphosphates, released from platelets, 
are able to activate FXII $[49,53,54]$. During the process of thrombus formation, FXII bound to fibrinogen can be activated and modulate fibrin structure. These findings indicate direct regulation of the fibrin fraction of the thrombus by FXIla and suggest that interference with FXIla mediated effects on fibrin may prove useful for the treatment of thrombosis.

\section{Acknowledgments}

This work was funded by the Netherlands Heart Foundation (grant 2008B120), the British Heart Foundation and the Medical Research Council. The authors acknowledge the excellent technical assistance of K. Beekers. 


\section{References}

1. Pechik I, Yakovlev S, Mosesson MW, Gilliland GL, Medved L. Structural basis for sequential cleavage of fibrinopeptides upon fibrin assembly. Biochemistry. 2006; 45: 3588-97.

2. Weisel JW. Fibrinogen and fibrin. Adv Protein Chem. 2005; 70: 247-99.

3. Collet JP, Park D, Lesty C, Soria J, Soria C, Montalescot G, Weisel JW. Influence of fibrin network conformation and fibrin fiber diameter on fibrinolysis speed: dynamic and structural approaches by confocal microscopy. Arterioscler Thromb Vasc Biol. 2000; 20: 1354-61.

4. Brown AE, Litvinov RI, Discher DE, Purohit PK, Weisel JW. Multiscale mechanics of fibrin polymer: gel stretching with protein unfolding and loss of water. Science. 2009; 325: 741-4.

5. Bhasin N, Ariens RA, West RM, Parry DJ, Grant PJ, Scott DJ. Altered fibrin clot structure and function in the healthy first-degree relatives of subjects with intermittent claudication. Journal of vascular surgery. 2008; 48: 1497-503, 503 e1.

6. Carter AM, Cymbalista CM, Spector TD, Grant PJ. Heritability of clot formation, morphology, and lysis: the EuroCLOT study. Arterioscler Thromb Vasc Biol. 2007; 27: 2783-9.

7. Collet JP, Allali Y, Lesty C, Tanguy ML, Silvain J, Ankri A, Blanchet B, Dumaine R, Gianetti J, Payot L, Weisel JW, Montalescot G. Altered fibrin architecture is associated with hypofibrinolysis and premature coronary atherothrombosis. Arterioscler Thromb Vasc Biol. 2006; 26: 2567-73.

8. Mills JD, Ariens RA, Mansfield MW, Grant PJ. Altered fibrin clot structure in the healthy relatives of patients with premature coronary artery disease. Circulation. 2002; 106: 1938-42.

9. Undas A, Szuldrzynski K, Stepien E, Zalewski J, Godlewski J, Tracz W, Pasowicz M, Zmudka K. Reduced clot permeability and susceptibility to lysis in patients with acute coronary syndrome: effects of inflammation and oxidative stress. Atherosclerosis. 2008; 196: 551-7.

10. Undas A, Zawilska K, Ciesla-Dul M, Lehmann-Kopydlowska A, Skubiszak A, Ciepluch K, Tracz W. Altered fibrin clot structure/function in patients with idiopathic venous thromboembolism and in their relatives. Blood. 2009; 114: 4272-8.

11. Colman RW, Schmaier AH. Contact system: a vascular biology modulator with anticoagulant, profibrinolytic, antiadhesive, and proinflammatory attributes. Blood. 1997; 90: 3819-43.

12. Renne T, Pozgajova M, Gruner S, Schuh K, Pauer HU, Burfeind P, Gailani D, Nieswandt B. Defective thrombus formation in mice lacking coagulation factor XII. $J$ Exp Med. 2005; 202: 271-81.

13. Decrem Y, Rath G, Blasioli V, Cauchie P, Robert S, Beaufays J, Frere JM, Feron O, Dogne JM, Dessy C, Vanhamme L, Godfroid E. Ir-CPI, a coagulation contact phase inhibitor from the tick Ixodes ricinus, inhibits thrombus formation without impairing hemostasis. J Exp Med. 2009; 206: 2381-95.

14. Kleinschnitz C, Stoll G, Bendszus M, Schuh K, Pauer HU, Burfeind P, Renne C, Gailani D, Nieswandt B, Renne T. Targeting coagulation factor XII provides protection from pathological thrombosis in cerebral ischemia without interfering with hemostasis. J Exp Med. 2006; 203: 513-8.

15. Pham M, Kleinschnitz C, Helluy X, Bartsch AJ, Austinat M, Behr VC, Renne T, Nieswandt B, Stoll G, Bendszus M. Enhanced cortical reperfusion protects coagulation factor XII-deficient mice from ischemic stroke as revealed by high-field MRI. Neuroimage. 2010; 49: 2907-14. 
16. Stavrou E, Schmaier AH. Factor XII: what does it contribute to our understanding of the physiology and pathophysiology of hemostasis \& thrombosis. Thromb Res. 2010; 125: 210-5.

17. Ny T, Elgh F, Lund B. The structure of the human tissue-type plasminogen activator gene: correlation of intron and exon structures to functional and structural domains. Proc Natl Acad Sci U S A. 1984; 81: 5355-9.

18. Cool DE, MacGillivray RT. Characterization of the human blood coagulation factor XII gene. Intron/exon gene organization and analysis of the 5 '-flanking region. $\mathrm{J} \mathrm{Biol}$ Chem. 1987; 262: 13662-73.

19. Govers-Riemslag JW, Janssen MP, Zwaal RF, Rosing J. Effect of membrane fluidity and fatty acid composition on the prothrombin-converting activity of phospholipid vesicles. Biochemistry. 1992; 31: 10000-8.

20. Govers-Riemslag JW, Smid M, Cooper JA, Bauer KA, Rosenberg RD, Hack CE, Hamulyak K, Spronk HM, Miller GJ, ten Cate H. The plasma kallikrein-kinin system and risk of cardiovascular disease in men. J Thromb Haemost. 2007; 5: 1896-903.

21. Reddigari SR, Shibayama Y, Brunnee T, Kaplan AP. Human Hageman factor (factor XII) and high molecular weight kininogen compete for the same binding site on human umbilical vein endothelial cells. J Biol Chem. 1993; 268: 11982-7.

22. Tans G, Griffin JH. Properties of sulfatides in factor-XII-dependent contact activation. Blood. 1982; 59: 69-75.

23. van Zandvoort M, Engels W, Douma K, Beckers L, Oude Egbrink M, Daemen M, Slaaf DW. Two-photon microscopy for imaging of the (atherosclerotic) vascular wall: a proof of concept study. J Vasc Res. 2004; 41: 54-63.

24. Mutch NJ, Engel R, Uitte de Willige S, Philippou H, Ariens RA. Polyphosphate modifies the fibrin network and down-regulates fibrinolysis by attenuating binding of tPA and plasminogen to fibrin. Blood. 2010; 115: 3980-8.

25. Ariens RA, Philippou H, Nagaswami C, Weisel JW, Lane DA, Grant PJ. The factor XIII V34L polymorphism accelerates thrombin activation of factor XIII and affects cross-linked fibrin structure. Blood. 2000; 96: 988-95.

26. Abou-Saleh RH, Connell SD, Harrand R, Ajjan RA, Mosesson MW, Smith DA, Grant PJ, Ariens RA. Nanoscale probing reveals that reduced stiffness of clots from fibrinogen lacking $42 \mathrm{~N}$-terminal Bbeta-chain residues is due to the formation of abnormal oligomers. Biophys J. 2009; 96: 2415-27.

27. Ajjan R, Lim BC, Standeven KF, Harrand R, Dolling S, Phoenix F, Greaves R, Abou-Saleh RH, Connell S, Smith DA, Weisel JW, Grant PJ, Ariens RA. Common variation in the $\mathrm{C}$-terminal region of the fibrinogen beta-chain: effects on fibrin structure, fibrinolysis and clot rigidity. Blood. 2008; 111: 643-50.

28. Evans RM, Tassieri M, Auhl D, Waigh TA. Direct conversion of rheological compliance measurements into storage and loss moduli. Phys Rev E Stat Nonlin Soft Matter Phys. 2009; 80: 012501.

29. Dunn EJ, Philippou H, Ariens RA, Grant PJ. Molecular mechanisms involved in the resistance of fibrin to clot lysis by plasmin in subjects with type 2 diabetes mellitus. Diabetologia. 2006; 49: 1071-80.

30. Fujikawa K, McMullen BA. Amino acid sequence of human beta-factor XIla. J Biol Chem. 1983; 258: 10924-33.

31. Borissoff Jl, Heeneman S, Kilinc E, Kassak P, Van Oerle R, Winckers K, GoversRiemslag JW, Hamulyak K, Hackeng TM, Daemen MJ, ten Cate H, Spronk HM. Early atherosclerosis exhibits an enhanced procoagulant state. Circulation. 2010; 122: 821-30.

32. Weisel JW, Nagaswami C. Computer modeling of fibrin polymerization kinetics correlated with electron microscope and turbidity observations: clot structure and assembly are kinetically controlled. Biophys J. 1992; 63: 111-28. 
33. Wolberg AS, Campbell RA. Thrombin generation, fibrin clot formation and hemostasis. Transfus Apher Sci. 2008; 38: 15-23.

34. Standeven KF, Uitte de Willige S, Carter AM, Grant PJ. Heritability of clot formation. Semin Thromb Hemost. 2009; 35: 458-67.

35. Wolberg AS. Thrombin generation and fibrin clot structure. Blood Rev. 2007; 21: 131-42.

36. Undas A, Zalewski J, Krochin M, Siudak Z, Sadowski M, Pregowski J, Dudek D, Janion M, Witkowski A, Zmudka K. Altered plasma fibrin clot properties are associated with in-stent thrombosis. Arterioscler Thromb Vasc Biol. 2010; 30: 27682.

37. Gabriel DA, Muga K, Boothroyd EM. The effect of fibrin structure on fibrinolysis. $J$ Biol Chem. 1992; 267: 24259-63.

38. Doggen CJ, Rosendaal FR, Meijers JC. Levels of intrinsic coagulation factors and the risk of myocardial infarction among men: Opposite and synergistic effects of factors XI and XII. Blood. 2006; 108: 4045-51.

39. Endler G, Marsik C, Jilma B, Schickbauer T, Quehenberger P, Mannhalter C. Evidence of a U-shaped association between factor XII activity and overall survival. J Thromb Haemost. 2007; 5: 1143-8.

40. Grundt H, Nilsen DW, Hetland O, Valente E, Fagertun HE. Activated factor 12 (FXIla) predicts recurrent coronary events after an acute myocardial infarction. Am Heart J. 2004; 147: 260-6.

41. Miller GJ, Esnouf MP, Burgess AI, Cooper JA, Mitchell JP. Risk of coronary heart disease and activation of factor XII in middle-aged men. Arterioscler Thromb Vasc Biol. 1997; 17: 2103-6.

42. Siegerink B, Govers-Riemslag JW, Rosendaal FR, Ten Cate H, Algra A. Intrinsic coagulation activation and the risk of arterial thrombosis in young women: results from the Risk of Arterial Thrombosis in relation to Oral contraceptives (RATIO) case-control study. Circulation. 2010; 122: 1854-61.

43. Weisel JW, Medved L. The structure and function of the alpha $C$ domains of fibrinogen. Ann N Y Acad Sci. 2001; 936: 312-27.

44. Collet JP, Moen JL, Veklich YI, Gorkun OV, Lord ST, Montalescot G, Weisel JW. The alphaC domains of fibrinogen affect the structure of the fibrin clot, its physical properties, and its susceptibility to fibrinolysis. Blood. 2005; 106: 3824-30.

45. Gebbink MF, Bouma B, Maas C, Bouma BN. Physiological responses to protein aggregates: fibrinolysis, coagulation and inflammation (new roles for old factors). FEBS Lett. 2009; 583: 2691-9.

46. Ponczek MB, Gailani D, Doolittle RF. Evolution of the contact phase of vertebrate blood coagulation. J Thromb Haemost. 2008; 6: 1876-83.

47. Burton RA, Tsurupa G, Medved L, Tjandra N. Identification of an ordered compact structure within the recombinant bovine fibrinogen alphaC-domain fragment by NMR. Biochemistry. 2006; 45: 2257-66.

48. Citarella F, Ravon DM, Pascucci B, Felici A, Fantoni A, Hack CE. Structure/function analysis of human factor XII using recombinant deletion mutants. Evidence for an additional region involved in the binding to negatively charged surfaces. Eur $J$ Biochem. 1996; 238: 240-9.

49. van der Meijden PE, Munnix IC, Auger JM, Govers-Riemslag JW, Cosemans JM, Kuijpers MJ, Spronk HM, Watson SP, Renne T, Heemskerk JW. Dual role of collagen in factor XII-dependent thrombus formation. Blood. 2009; 114: 881-90.

50. Kaplan AP, Ghebrehiwet B. The plasma bradykinin-forming pathways and its interrelationships with complement. Mol Immunol. 2010; 47: 2161-9.

51. LaRusch GA, Mahdi F, Shariat-Madar Z, Adams G, Sitrin RG, Zhang WM, McCrae $\mathrm{KR}$, Schmaier $A H$. Factor XII stimulates ERK1/2 and Akt through uPAR, integrins, and the EGFR to initiate angiogenesis. Blood. 2010; 115: 5111-20. 
52. Schmaier AH, Larusch G. Factor XII: New life for an old protein. Thromb Haemost. 2010; 104: 915-8.

53. Maas C, Govers-Riemslag JW, Bouma B, Schiks B, Hazenberg BP, Lokhorst HM, Hammarstrom P, ten Cate H, de Groot PG, Bouma BN, Gebbink MF. Misfolded proteins activate factor XII in humans, leading to kallikrein formation without initiating coagulation. J Clin Invest. 2008; 118: 3208-18.

54. Muller F, Mutch NJ, Schenk WA, Smith SA, Esterl L, Spronk HM, Schmidbauer S, Gahl WA, Morrissey JH, Renne T. Platelet polyphosphates are proinflammatory and procoagulant mediators in vivo. Cell. 2009; 139: 1143-56. 


\section{Supplemental data}

Table S2.1. Effect of FXII concentration on permeation of the clot

\begin{tabular}{ccc}
\hline & $\mathbf{1} \boldsymbol{\mu M}$ sulfatides & $\mathbf{0 . 4} \boldsymbol{\mu M}$ sulfatides + $\mathbf{5} \mathbf{~ M}$ thrombin \\
\hline Concentration FXII (\%) & $\mathrm{Ks}\left(\mathrm{cm}^{2} \times 10^{-9}\right)^{\#}$ & $\mathrm{Ks}\left(\mathrm{cm}^{2} \times 10^{-9}\right)$ \\
$\mathbf{1}$ & 33.2 & 15.5 \\
$\mathbf{1 0}$ & 26.4 & 7.4 \\
$\mathbf{1 0 0}$ & 19.3 & 7.9 \\
\hline \# &
\end{tabular}

\# The coefficient of permeability, the Darcy constant Ks represents the average pore size of the fibrin structure by measuring the flow rate of a buffer through a fibrin clot. Using the flow rate and the following equation: $K s=(Q \times L \times \eta) /(T \times A \times P)$, the Darcy constant $\mathrm{Ks}$ in $\mathrm{cm}^{2}$ can be calculated. $(\mathrm{Q}=$ volume of liquid $(\mathrm{ml}), \mathrm{L}=$ clot length $(\mathrm{cm}), \eta=$ viscosity (poise), $\mathrm{T}=$ time $(\mathrm{s}), \mathrm{A}=$ cross-sectional area $\left(\mathrm{cm}^{2}\right)$, and $\mathrm{P}=$ pressure drop $(\mathrm{dyne} / \mathrm{cm})$. The experiments are based on clots made with FXII-deficient plasma to which purified FXII was added at the concentrations indicated above, and clotting (in the presence of calcium and phospholipid vesicles) was triggered with sulfatides and thrombin or sulfatides alone.

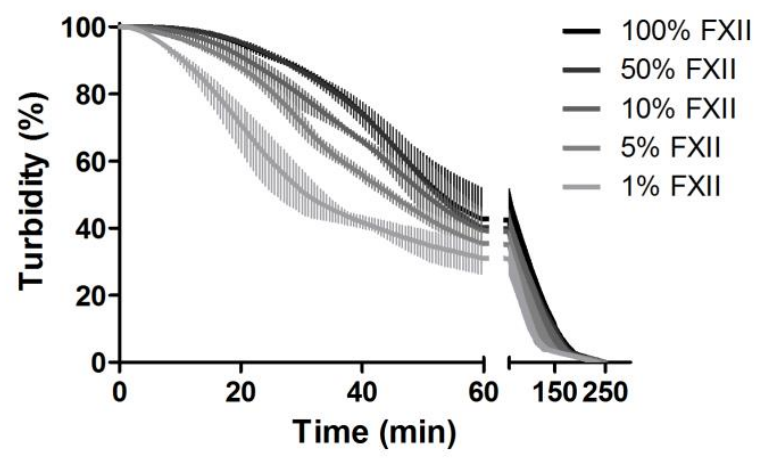

Figure S2.1. Effect of FXII(a) on fibrinolysis rates.

FXII-deficient plasma was reconstituted with purified FXII and clotting was initiated via contact activation with sulfatides, in the presence of phospholipid vesicles and $\mathrm{CaCl}_{2}$. Turbidity was monitored every $15 \mathrm{~s}$ at $405 \mathrm{~nm}$ for 5 hours at $37^{\circ} \mathrm{C}$. Final concentrations were $76 \%$ plasma, a range of FXII concentrations ( $0 \%-100 \%$ of normal plasma concentration), $0.1 \mu \mathrm{g} / \mathrm{ml}$ tPA, $4 \mu \mathrm{M}$ sulfatides, $4 \mu \mathrm{M}$ phospholipid vesicles (DOPS/DOPC/DOPE, 20/60/20) and $16 \mathrm{mM} \mathrm{CaCl}_{2}$. For clarity, the curves only show the lysis phase. The figure shows the mean \pm range of three measurements. 

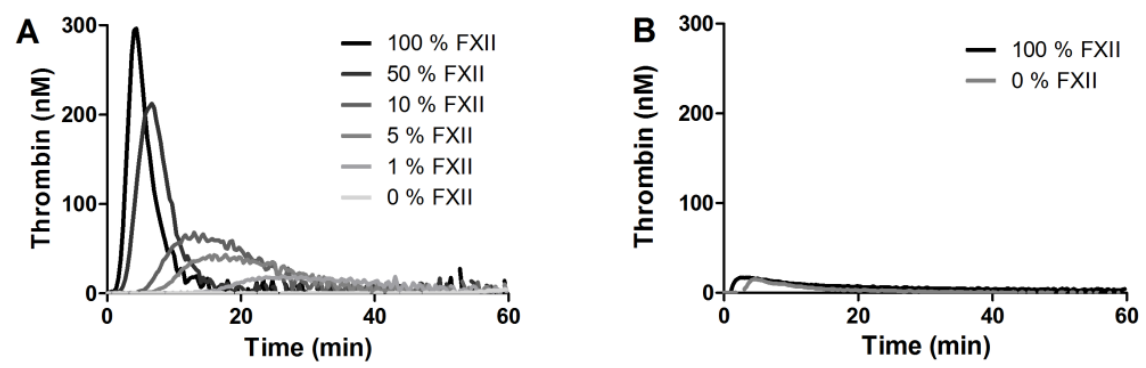

Figure S2.2. Thrombin generation at varying FXII concentrations.

FXII-deficient plasma or plasma deficient in both FXII and prothrombin was supplemented with increasing amounts of purified FXII as indicated in the figure. Contact activation was triggered with sulfatides in the presence of phospholipid vesicles and immediately thereafter the determination of thrombin generation was started with the addition of fluorogenic $\mathrm{AMC}$ substrate and $\mathrm{CaCl}_{2}$ and was followed continuously in plasma. Final concentrations were $67 \%$ plasma, $0.4 \mu \mathrm{M}$ sulfatides, $4 \mu \mathrm{M}$ phospholipid vesicles (DOPS/DOPC/DOPE, 20/60/20) and $16 \mathrm{mM} \mathrm{CaCl}_{2}$. Panel A shows FXIIdeficient plasma and panel B shows plasma deficient in both FXII and prothrombin. Each thrombin generation curve is based on the mean of two experiments.

Table S2.2. Effect of different amounts of FXII on thrombin generation

\begin{tabular}{lccc}
\hline Deficient plasma & $\begin{array}{c}\text { FXII added to } \\
\text { Plasma (\%) }\end{array}$ & $\begin{array}{c}\text { Peak height } \\
\text { (nM Ila) }\end{array}$ & $\begin{array}{c}\text { ETP } \\
\text { (nM lla.min) }\end{array}$ \\
\hline FXII-deficient plasma & 100 & 295.0 & 1317 \\
\hline FXII-deficient plasma & 50 & 211.7 & 1267 \\
\hline FXII-deficient plasma & 10 & 64.1 & 1065 \\
\hline FXII-deficient plasma & 5 & 40.6 & 820 \\
\hline FXII-deficient plasma & 1 & 17.8 & 504 \\
\hline FXII-deficient plasma & 0 & 7.7 & No tail \\
\hline FXII and PT deficient plasma & 100 & & No tail \\
FXII and PT deficient plasma & 0 & 16.2 & No tail \\
\hline
\end{tabular}

ETP: Endogenous thrombin potential or area under the curve; PT: prothrombin. 


\section{Factor XII}
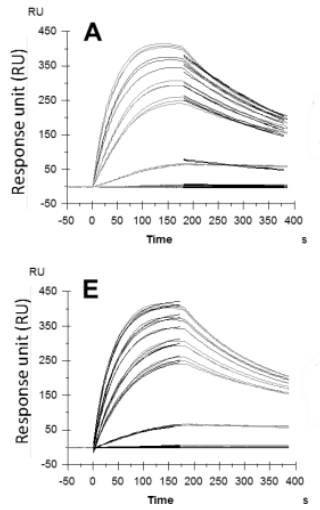
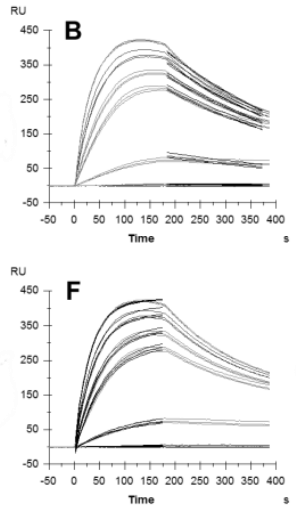

a-Factor XIla
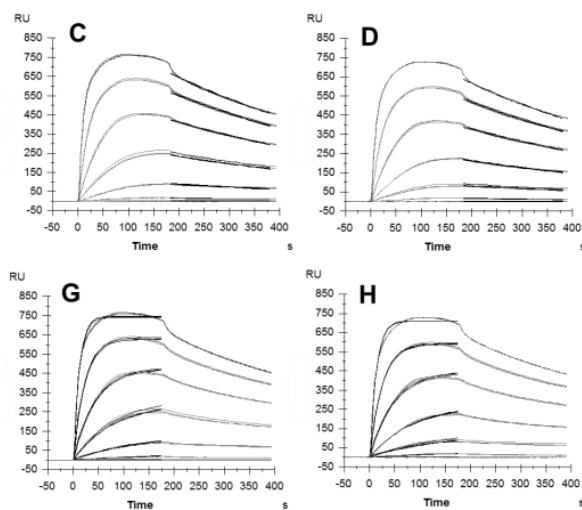

Figure S2.3. Surface plasmon resonance analysis of the binding between FXII/aFXIla and fibrinogen/fibrin.

Data were analyzed by a $1: 1$ binding model with separate kd fitting (black lines, top panels $A-D$ ) and ka fitting (black lines, bottom panel $E-H)$. Panels $A$ and $B$ show binding of (from top to bottom) $25 \mathrm{nM}, 20 \mathrm{nM}, 15 \mathrm{nM}, 12.5 \mathrm{nM}, 6.25 \mathrm{nM}, 3.1 \mathrm{nM}, 1.6 \mathrm{nM}$ and $0 \mathrm{nM}$ FXII to fibrinogen and fibrin respectively. Panels $C$ and D show binding of (from top to bottom) $200 \mathrm{nM}, 100 \mathrm{nM}, 50 \mathrm{nM}, 25 \mathrm{nM}, 12.5 \mathrm{nM}, 6.25 \mathrm{nM}, 3.1 \mathrm{nM}, 1.6 \mathrm{nM}$ and $0 \mathrm{nM}$ a-FXIla to fibrinogen and fibrin respectively. Panels $\mathrm{E}-\mathrm{H}$ show the same binding experiments as A-D, but with ka-fitting. Each binding curve is shown in triplicate.

\section{$\beta$-Factor XIla}
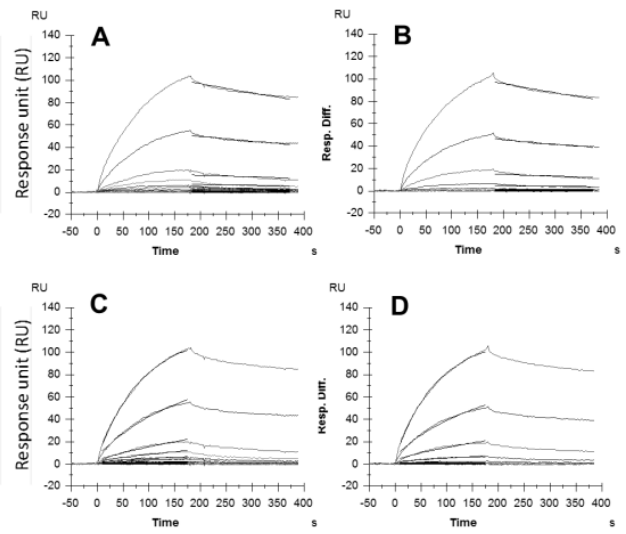

Figure S2.4. Surface plasmon resonance analysis of the binding between $\beta$-FXIla and fibrinogen/fibrin.

Data were analyzed by a 1:1 binding model with separate kd fitting (top panels) and ka fitting (bottom panels). Panels A and B show binding of (from top to bottom) $1250 \mathrm{nM}$, $625 \mathrm{nM}, 312.5 \mathrm{nM}, 156.3 \mathrm{nM}, 78.1 \mathrm{nM}, 39.1 \mathrm{nM}, 19.5 \mathrm{nM}, 9.8 \mathrm{nM}, 4.9 \mathrm{nM}$ and $0 \mathrm{nM}$ $\beta$-FXIla to fibrinogen and fibrin respectively. Panels $C$ and $D$ show the same binding experiments as $A$ and $B$, but with ka-fitting. 


\section{Chapter 3}

\section{Dual role for factor XII in coagulation and fibrinolysis}

J. Konings, L.R. Hoving, R.A.S. Ariëns, E. Smith, M. Ninivaggi, L.J. Hardy, B. de Laat, H. ten Cate, H. Philippou, J.W.P. Govers-Riemslag

Submitted 


\section{Chapter 3}

\section{Abstract}

Background and objectives: Activated coagulation factor XII ( $\alpha-F X I l a)$ is able to bind to fibrin(ogen) and increase the density and stiffness of the fibrin clot. Conversely, the proteins of the contact system and the fibrinolytic system show a high degree of homology and FXIla can convert plasminogen into plasmin. Therefore, we studied the contribution of $\alpha-F X I l a$ to overall clot stability and fibrinolysis in the absence and presence of tissue plasminogen activator (tPA). Methods and results: We observed that $\alpha-F X I l a$ directly converted plasminogen into plasmin and reduced clot lysis time at all tPA concentrations tested (0 $1500 \mathrm{pM}$ ). Simultaneous assessment of plasmin generation (with the chromogenic substrate S-2251) alongside turbidity measurements, showed earlier onset of plasmin formation in the presence of $\alpha$-FXIla. Fibrinolysis of clots formed under flow conditions, revealed that incorporation of $\alpha-F X I l a$, together with plasminogen, into the clot accelerated clot break-down and increased plasmin generation by TPA, compared to clots prepared in the absence of $\alpha-F X I l a$. Scanning electron microscopy (SEM) revealed that the pore size increased more in the presence than in the absence of $\alpha$-FXlla when fibrinolysis was initiated with TPA during clot formation.

Conclusions: $\alpha$-FXIla enhanced fibrinolysis, irrespective of whether tPA was present during clot formation or was added afterwards to initiate fibrinolysis. Visualization by SEM showed that in the presence of $\alpha$-FXIla, the clot lysed faster. We postulate that FXIla first strengthens the clot structure during clot formation and thereafter helps to initiate fibrinolysis. 


\section{Introduction}

Coagulation factor XII (FXII) is an $80 \mathrm{kDa}$ serine protease consisting of a heavy (353 residues) and a light chain (243 residues) held together by a disulfide bond and is part of the contact activation system. FXII and its activated form FXIla play a role in several physiological processes, such as coagulation, fibrinolysis and angiogenesis. Activation of FXII initiates the intrinsic pathway of coagulation and via sequential activation of coagulation factors XI, IX, VIII and $\mathrm{X}$, thrombin is generated, which converts fibrinogen into fibrin. Furthermore, FXIla participates in the fibrinolytic system. There is a high degree of homology between the proteins of the contact system and those of the fibrinolytic system: FXII is homologous to tissue plasminogen activator (tPA) and the two main substrates of FXIla, prekallikrein and FXI, are homologous to plasminogen [1]. FXIla, FXla and kallikrein can all three convert plasminogen to plasmin, however, at a lower rate than IPA and urokinase plasminogen activator (UPA) [2-5].

Fibrinolysis is the process whereby fibrin clots are degraded by plasmin [6]. Plasmin is generated from plasminogen by plasminogen activators, among which IPA and UPA are the most important physiologically. During clot formation, little fibrinolysis takes place, due to inhibition of the fibrinolytic system by plasminogen activator inhibitor-1 (PAI-1) which inhibits IPA and UPA, and a2antiplasmin which inhibits plasmin. The binding of tPA and plasminogen to partially cleaved fibrin (which exposes free lysines for further IPA and plasminogen binding) results in enhanced plasmin generation. This is regulated by thrombin-activatable fibrinolysis inhibitor (TAFI). When activated, TAFla cleaves the free lysines exposed on fibrin and thereby reduces the enhanced rate of plasmin generation [7]. Eventually, fibrin plays a crucial role in its own degradation due to increased plasmin generation: the activation of plasminogen by IPA is greatly enhanced in the presence of fibrin, but not in the presence of fibrinogen [8]. This mechanism restricts fibrinolysis to the site of the clot. This is important to protect fibrinogen and other plasma proteins from degradation by plasmin.

An important determinant of the rate of clot dissolution is the structure of the fibrin clot [9]. Dense fibrin clots, characterized by thin fibers and small pores, are more difficult to lyse than looser structures. The mechanisms underpinning this may include restricted access of fibrinolytic factors to a denser clot, but also reduced binding of plasminogen and its activators thereby reducing plasmin generation rates [10-12]. Recently, we have shown that $\alpha-F X I l a$ is able to 


\section{Chapter 3}

change the fibrin clot structure: in the presence of $\alpha$-FXIla denser fibrin clots were formed composed of thinner fibers [13]. In general, dense fibrin clot structures have been associated with decreased fibrinolysis [9]. However, activated FXII (FXIla) is also capable of stimulating fibrinolysis by activation of plasminogen [5].

Because of these potentially counteracting mechanisms by which FXIla could influence fibrinolysis, the aim of our current study was to investigate the effects of $\alpha$-FXIla on fibrinolysis in clots made under the influence of FXIla. We determined the ability of $\alpha$-FXIla to form plasmin from plasminogen and we determined the effect of $\alpha-F X I l a$ on fibrinolysis, both under static conditions and in flow conditions. Furthermore, we visualized the effect of FXIla on fibrinolysis using scanning electron microscopy (SEM).

\section{Materials and methods}

\section{Materials}

Human plasminogen-free fibrinogen, $\alpha-F X I l a$, plasminogen and thrombin were from Enzyme Research Laboratories (Swansea, UK). Fibrinogen AlexaFluor488 was from Molecular probes, Invitrogen (Carlsbad, CA). Chromogenic substrates S-2251 was from Chromogenix (Milano, Italy). Recombinant tissue typeplasminogen activator (t-PA) was from Boehringer Ingelheim (Alkmaar, the Netherlands). Osmium tetroxide and sodium cacodylate were from Electron Microscopy Sciences (Hatfield, PA). Bovine serum albumin (BSA), gluteraldehyde and hexamethyldisilazane (HMDS) were from Sigma-Aldrich (St Louis, USA). Ethanol was from Merck (Darmstadt, Germany).

\section{Fibrin coated plates}

Maxisorb 96-well plates (NUNC, Roskilde, Denmark) were coated with $100 \mu \mathrm{g} / \mathrm{ml}$ fibrinogen in Hepes-buffer (25 mM Hepes, $150 \mathrm{mM} \mathrm{NaCl}, \mathrm{pH}=7.5$ ) at $4{ }^{\circ} \mathrm{C}$ for 18 hours. The plate was blocked with $3 \%$ w/v BSA $0.01 \%$ Tween-20 in Hepes-buffer for 90 minutes at $37^{\circ} \mathrm{C}$. Fibrinogen was converted to fibrin with $10 \mathrm{nM}$ thrombin, $5 \mathrm{mM} \mathrm{CaCl} 2$ in $0.5 \%$ w/v BSA in Hepes-buffer for 1 hour at room temperature and was washed 3 times to remove thrombin with Hepesbuffer containing $750 \mathrm{mM} \mathrm{NaCl}$ and then with Hepes-buffer containing $150 \mathrm{mM}$ $\mathrm{NaCl}$. These coated plates were used to assess plasmin generation on fibrin. 
Plasmin generation assay

Plates coated with fibrin or low binding polystyrene 96-well plates (Greiner, Frickenhauser, Germany) were used. Fibrinogen (0 - $1 \mathrm{mg} / \mathrm{ml})$, plasminogen $(75 \mathrm{nM})$ and $\alpha$-FXIla $(0-125 \mathrm{nM})$ in Hepes-buffer $(\mathrm{pH}=7.5)$ were added to the plate and the measurement was started after tPA $(0-150 \mathrm{pM})$ and the chromogenic substrate S-2251 $(0.8 \mathrm{mM})$ were added. The amidolytic activity was recorded at $405 \mathrm{~nm}$ for 5 hours, every $25 \mathrm{~s}$ at $37^{\circ} \mathrm{C}$ with an ELx808 plate reader (Biotek Instruments, Winooski, VT).

Fibrin formation and fibrinolysis by turbidity

Fibrin polymerization was monitored in low binding 96-wells plates by the change in turbidity at $405 \mathrm{~nm}\left(\mathrm{~A}_{405}\right)$ every $15 \mathrm{~s}$, for at least 1.5 hours at $37^{\circ} \mathrm{C}$.

Fibrinogen ( $0.5,1$ or $3 \mathrm{mg} / \mathrm{ml}$ ), plasminogen (240 or $300 \mathrm{nM}$ ), $\alpha-F X I l a$ (varying concentrations between 0 and $375 \mathrm{nM}$ ) and tPA (varying concentrations between 0 and $1500 \mathrm{pM})$ were added to thrombin $(2.5 \mathrm{nM})$ and $\mathrm{CaCl}_{2}(5 \mathrm{mM})$ in Hepes-buffer $(\mathrm{pH}=7.5)$. All concentrations are final concentrations.

To monitor plasmin activity and clot turbidity simultaneously and under the same reaction conditions, parallel clots were prepared with fibrinogen $(1 \mathrm{mg} / \mathrm{ml})$, plasminogen (300 nM), tPA (50 pM), thrombin (2.5 nM), $\mathrm{CaCl}_{2}(5 \mathrm{mM})$ and either S-2251 (0.45 mM) or Hepes-buffer. Readings were taken at $405 \mathrm{~nm}$. Plasmin activity was detected in the samples containing S-2251, from which the signal arising from the changing turbidity of the forming and lysing clot was subtracted.

\section{Chandler loop}

Fibrinolysis was monitored by incorporating $5 \%(\mathrm{w} / \mathrm{w})$ fibrinogen, labeled with a fluorescent tag, into the forming clot and measuring the amount of label released as fibrin degradation products during fibrinolysis in Hepes-buffer $(0.5 \%$ $\mathrm{w} / \mathrm{v} \mathrm{BSA}, \mathrm{pH}=7.5$ ) containing $7.14 \mathrm{nM}$ tPA.

Thrombin $(2.5 \mathrm{nM})$, a-FXIla $(62.5 \mathrm{nM})$ and $\mathrm{CaCl}_{2}(5 \mathrm{mM})$ were added to fibrinogen $(0.25 \mathrm{mg} / \mathrm{ml} ; 5 \%(\mathrm{w} / \mathrm{w})$ Fibrinogen AlexaFluor488) and plasminogen $(183 \mathrm{nM})$ in a final volume of $1 \mathrm{ml}$. The mixture was transferred in vinyl tubing (inner diameter $3 \mathrm{~mm}$, external diameter $4.2 \mathrm{~mm}$, length $33 \mathrm{~cm}$; Portex, Hythe, Kent) and the open ends were joined using a short sleeve of larger tubing to form a Chandler loop with a diameter of $10.5 \mathrm{~cm}$. Loops were attached around an axle which passed through the center of the loops on a turntable, and the axle rotated at $30 \mathrm{rpm}$ for $90 \mathrm{~min}$ at room temperature [14]. A single clot was formed, removed and transferred to an Eppendorf tube containing $500 \mu$ of tPA $(7.14 \mathrm{nM})$ in Hepes-buffer $(0.5 \% \mathrm{w} / \mathrm{v} \mathrm{BSA})$. The tubes were placed on a roller 


\section{Chapter 3}

mixer (Stuart, UK) and samples were taken at different time intervals for fluorescent and plasmin activity measurements: for each measurement $5 \mu \mathrm{l}$ sample was added to $195 \mu \mathrm{l}$ (fluorescent measurement) or $95 \mu \mathrm{l}$ (plasmin activity) Hepes-buffer (0.5\% w/v BSA, $\mathrm{pH}=7.5)$. Released fluorescence was measured with an excitation wavelength of $485 \mathrm{~nm}$, an emission wavelength of $438 \mathrm{~nm}$ and a cut-off value of $515 \mathrm{~nm}$ (SPECTRAmax M2 microplate reader). Plasmin activity was measured with the chromogenic substrate S-2251 at a final concentration of $0.45 \mathrm{mM}$.

\section{Scanning electron microscopy}

To visualize the fibrinolysis process, fibrinogen $(1 \mathrm{mg} / \mathrm{ml})$, plasminogen $(300 \mathrm{nM}), \alpha-F X I l a(0$ or $125 \mathrm{nM})$ and tPA $(0$ or $300 \mathrm{pM})$ were clotted with thrombin $(0.5 \mathrm{nM})$ and $\mathrm{CaCl}_{2}(5 \mathrm{mM})$ on Sefar (sieve mesh, pores: $\left.170 \mu \mathrm{m}\right)$ during $30 \mathrm{~min}$. After $30 \mathrm{~min}$, the clots were fixed with $2.5 \%$ gluteraldehyde overnight. After washing the samples, osmium tetroxide in sodium cacodylate was added for 1 hour. Next, the samples were dehydrated with a gradient of ethanol and HMDS and the samples were left to dry. The samples were mounted onto aluminum pin studs with $12 \mathrm{~mm}$ carbon conductive tabs (both Ted Pella, Inc.) and sputter coated with gold (Quorum Technologies Ltd, Ashford, Kent England; vacuum pump: EDWARDS, Crawley, West Sussex, UK).

The samples were photographed with a Phenom G2 Pro desktop SEM (Phenom World, Eindhoven, The Netherlands) using Phenom Pro Suite software. Every condition was performed in triplo and photographed in 10 different areas of the clot.

\section{Data analysis}

Data are expressed as mean \pm standard deviation (SD). Statistical analysis was performed using one-way analysis of variance (ANOVA), Bonferroni for post hoc comparison, or $t$ test with PRISM for Windows, version 5.00 (GraphPad Software, San Diego, CA, USA). $P$ values less than 0.05 were considered statistically significant.

\section{Results}

\section{Plasmin formation}

First, we determined the potential of $\alpha-F X I l a$ to convert plasminogen to plasmin. Therefore we performed plasmin formation assays in buffer and in a solution of 
fibrinogen $(1 \mathrm{mg} / \mathrm{ml})$. The conversion of the chromogenic substrate S-2251, was used to detect plasmin formation. Figure 3.1A shows that $\alpha-F X I l a$ was able to form plasmin from plasminogen both in buffer and in a solution containing fibrinogen in a dose dependent manner. More plasmin was formed if no fibrinogen was present. Next, we determined the conversion of plasminogen to plasmin by a-FXIla on top of a layer of fibrin (Figure 3.1B) and observed a dosedependent increase in plasmin formation. We repeated this experiment in the presence of 15 and $150 \mathrm{pM} \mathrm{tPA}$ and observed that at $15 \mathrm{pM}$ tPA, $\alpha$-FXIla shortened the time to measurable plasmin formation (from $97 \pm 1.7 \mathrm{~min}$ in the absence to $54 \pm 4.2 \mathrm{~min}$ and $56 \pm 1.5 \mathrm{~min}$ in the presence of $30 \mathrm{nM}$ and $60 \mathrm{nM}$ $\alpha$-FXIla, $p<0.001$ respectively). At 150 pM tPA, $\alpha$-FXlla did not have an additional effect on plasmin formation (Figure 3.1C,D).
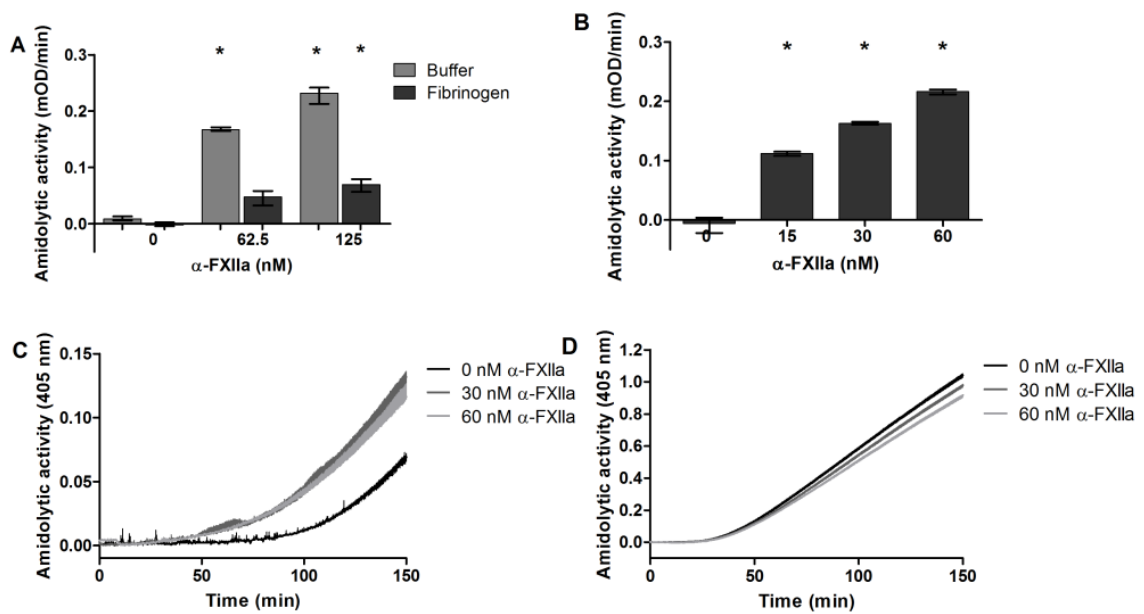

Figure 3.1. Conversion of plasminogen into plasmin by a-FXIla.

(A) Hepes buffer or fibrinogen was incubated with plasminogen (75 nM), a-FXIla (0, 62.5 and $125 \mathrm{nM}$ ) and S-2251 $(0.8 \mathrm{mM})$. The formation of plasmin was measured at $405 \mathrm{~nm}$ $(n=3)$. (B - D) A maxisorb plate was coated with $100 \mu \mathrm{g} / \mathrm{ml}$ fibrinogen, which was converted to fibrin with thrombin $(10 \mathrm{nM})$ and $\mathrm{CaCl}_{2}(5 \mathrm{mM})$. Plasminogen $(75 \mathrm{nM})$, a-FXIla $(0,30$ or $60 \mathrm{nM})$ in the absence (B) or presence of $15 \mathrm{pM} \mathrm{tPA}$ (C) or $150 \mathrm{pM} \mathrm{tPA}$ (D) and S-2251 $(0.8 \mathrm{mM})$ were added to the plate. The formation of plasmin was measured at $405 \mathrm{~nm}(n=3)$. Bars and curves represent mean \pm range $\left({ }^{*} p<0.05\right.$ compared to $0 \mathrm{nM} \alpha-\mathrm{FXIla)}$.

Turbidity and fibrinolysis

Next, we determined the effect of $\alpha$-FXIla in clotting assays. First, we measured fibrin formation and subsequent fibrinolysis by tPA $(0,15,150$ or $1500 \mathrm{pM})$ in 


\section{Chapter 3}

the absence and presence of $\alpha-\mathrm{FXIla}(0-125 \mathrm{nM})$ (Figure 3.2). We observed that fibrinolysis was enhanced by $\alpha-F X I l a:$ at all concentrations of tPA tested, the clot lysis time was reduced in the presence of $\alpha$-FXIla, but at higher IPA concentrations the effect of $\alpha-F X I l a$ on fibrinolysis was masked by the stronger effect of tPA. Furthermore, we tested a series of $\alpha$-FXIla concentrations at 0.5 $\mathrm{mg} / \mathrm{ml}$ fibrinogen at a fixed tPA concentration of $78.8 \mathrm{pM}$ (Table 3.1). $\alpha$-FXIla reduced maximal absorbance and enhanced fibrinolysis (reduction in clot lysis time and increased lysis rate) in a dose-dependent manner. The same effect of $\alpha-F X I l a$ on the maximal absorbance and the fibrinolysis parameters was seen at $3 \mathrm{mg} / \mathrm{ml}$ fibrinogen (data not shown). In the absence of tPA, high concentrations of $\alpha$-FXIla were needed to form enough plasmin to accomplish fibrinolysis (data not shown).
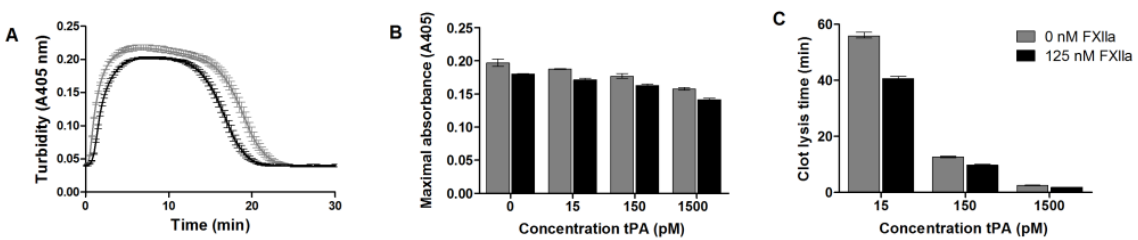

Figure 3.2. Effect of $\alpha-F X$ Ila on maximal absorbance and clot lysis time at different tPA concentrations.

$(A-C)$ Fibrinogen $(1 \mathrm{mg} / \mathrm{ml})$, plasminogen $(300 \mathrm{nM})$ and $\alpha$-FXIla $(0$ or $125 \mathrm{nM})$ were mixed with thrombin $(2.5 \mathrm{nM}), \mathrm{CaCl}_{2}(5 \mathrm{mM})$ tPA $(0,15,150$ or $1500 \mathrm{pM})$. Changes in absorbance were measured at $405 \mathrm{~nm}$. (A) Turbidimetric curves of fibrin formation and fibrinolysis in the presence of 150 pM tPA. (B) Maximal absorbance and (C) clot lysis time at different tPA concentrations $(n=3)$. Bars and curves represent mean \pm range.

Table 3.1: Effect of $\alpha-F X$ Ila on fibrinolytic parameters in turbidimetric assays.

\begin{tabular}{cccc}
\hline [a-FXIla] $(\mathrm{nM})$ & Maximal absorbance & Clot lysis time $(\mathbf{m i n})$ & Lysis rate $(\mathrm{OD} / \mathbf{s})$ \\
\hline $\mathbf{0}$ & $0.22 \pm 0.01$ & $101.30 \pm 29.67$ & $-22.6 \times 10^{-6} \pm 4.2 \times 10^{-6}$ \\
$\mathbf{2 0}$ & $0.22 \pm 0.01$ & $100.20 \pm 20.39$ & $-24.3 \times 10^{-6} \pm 4.3 \times 10^{-6}$ \\
$\mathbf{4 1}$ & $0.20 \pm 0.02$ & $77.70 \pm 23.45$ & $-27.9 \times 10^{-6} \pm 5.3 \times 10^{-6}$ \\
$\mathbf{8 1}$ & $0.20 \pm 0.01$ & $70.57 \pm 20.34$ & $-31.2 \times 10^{-6} \pm 4.6 \times 10^{-6}$ \\
$\mathbf{1 6 3}$ & $0.18 \pm 0.01$ & $60.50 \pm 6.53$ & $-34.5 \times 10^{-6} \pm 4.5 \times 10^{-6}$ \\
$\mathbf{3 2 5}$ & $0.18 \pm 0.01$ & $49.88 \pm 4.47$ & $-39.5 \times 10^{-6} \pm 2.1 \times 10^{-6}$ \\
\hline
\end{tabular}

The data are expressed as mean \pm standard deviation (SD)

Clots were formed with $0.5 \mathrm{mg} / \mathrm{ml}$ fibrinogen, $240 \mathrm{nM}$ plasminogen, $2.5 \mathrm{nM}$ thrombin, $5 \mathrm{mM} \mathrm{CaCl}_{2}$ and $78.8 \mathrm{pM} \mathrm{tPA}$

Since $\alpha$-FXIla produced a clot with a lower turbidity, characteristic for a clot with thinner fibrin fibers, which is normally more difficult to lyse, we wanted to 
determine if the enhanced fibrinolysis was caused by the formation of additional plasmin from plasminogen by $\alpha$-FXlla. Therefore, we repeated the turbidity experiment with $50 \mathrm{pM}$ of TPA in the presence or absence of the chromogenic substrate S-2251. In this manner, we were able to determine the amount of plasmin formed during fibrinolysis. Figure 3.3 shows that in the presence of $\alpha$ FXIla, plasmin formation started earlier and coincided with the start of fibrinolysis. Furthermore, in the presence of $\alpha$-FXIla more plasmin was formed. This is in agreement with the fact that in the turbidity experiments in the presence of $\alpha$-FXIla the clots lysed faster.

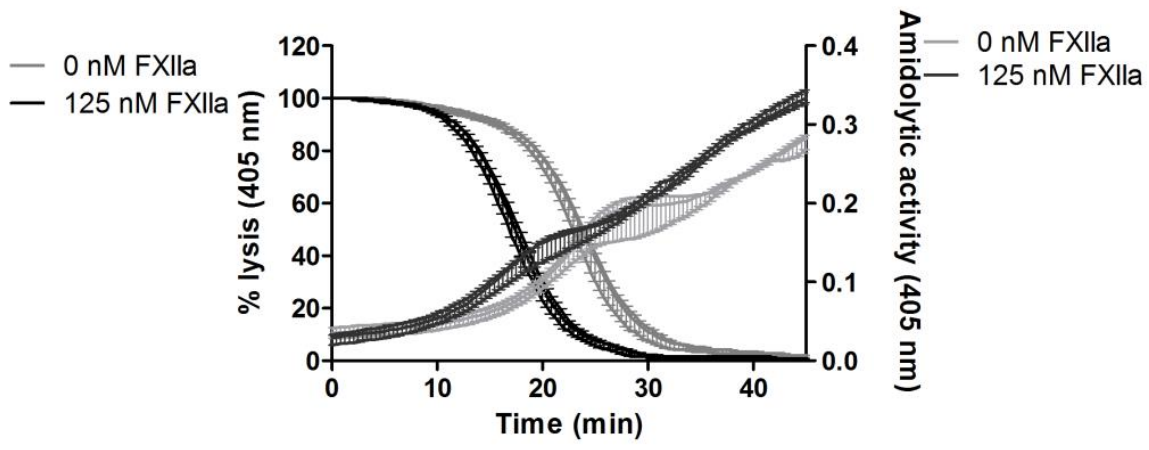

Figure 3.3. Simultaneous measurement of fibrinolysis and plasmin formation.

Fibrinogen $(1 \mathrm{mg} / \mathrm{ml})$, plasminogen $(300 \mathrm{nM})$ and $\alpha-\mathrm{FXIla}(0$ or $125 \mathrm{nM})$ in the presence or absence of S-2251 were added to a mix of tPA (50 pM), thrombin $(2.5 \mathrm{nM})$ and $\mathrm{CaCl}_{2}$ (5 mM). Fibrin formation and fibrinolysis (measured as changes in turbidity) and the formation of plasmin (measured as the conversion of S-2251) were measured at $405 \mathrm{~nm}$. The curves without S-2251 were subtracted from those in the presence of S-2251 to correct for turbidity $(n=3)$. Curves represent mean \pm range.

\section{Chandler loop}

In the previous experiments, tPA was incorporated into the clot. Furthermore, these clots were made under static conditions. To determine the effect of external fibrinolysis, we made fibrin clots under flow conditions inside a Chandler loop. At different time intervals we took samples to measure fibrinolysis (expressed as the increase in fluorescence release due to degradation of fluorescent fibrin) and the formation of plasmin (measured with the chromogenic substrate S-2251). During clot formation, no measurable plasmin was formed. In the presence of $\alpha-F X I l a$, fibrinolysis started at an earlier time point (significantly more fluorescence in the presence of $\alpha-F X I l a$ at time point $150 \mathrm{~min}$ ) and more plasmin was formed (significantly more plasmin formed in the presence of $\alpha-$ FXIla from time point $120 \mathrm{~min}$ on) (Figure 3.4). 
When clots were formed in the absence of plasminogen, addition of tPA and / or $\alpha-F X I l a$ to the clots did not result in fibrinolysis. This indicates that IPA and $\alpha-F X I l a$ induced fibrinolysis via activation of plasminogen into plasmin (data not shown).
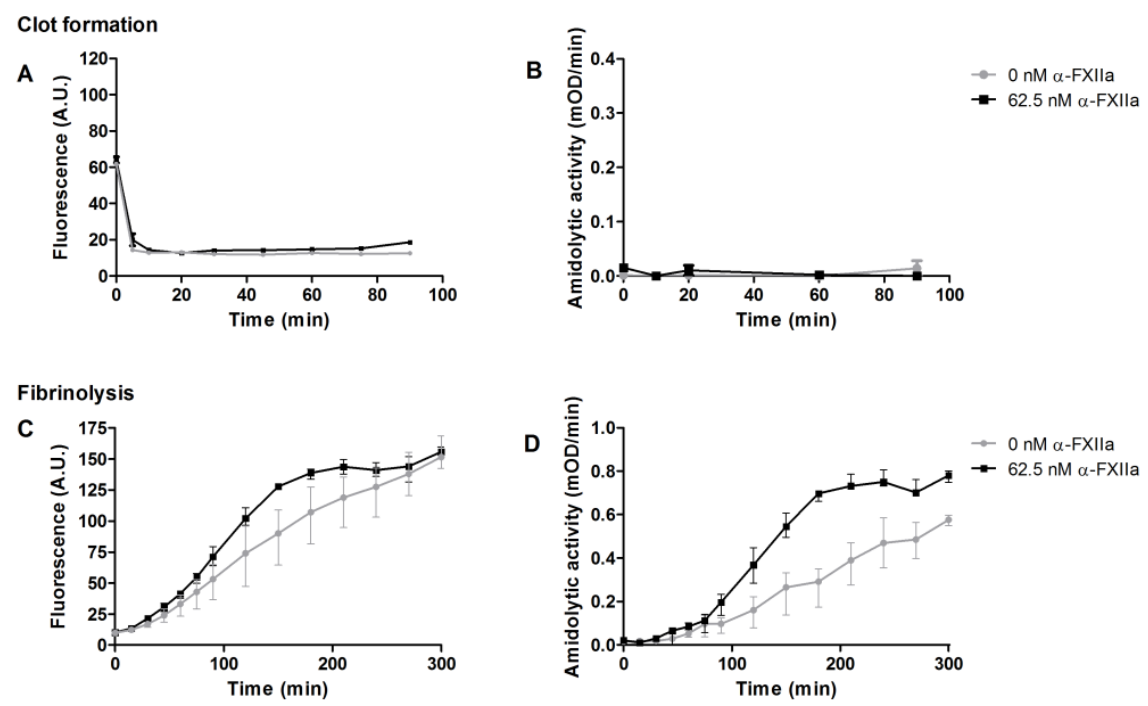

Figure 3.4. The effect of $\alpha-F X l l a$ on fibrinolysis and plasmin formation in clots formed under flow.

Fibrinogen $(0.25 \mathrm{mg} / \mathrm{ml}, 5 \%(\mathrm{w} / \mathrm{w})$ labeled with AlexaFluor488), plasminogen $(183 \mathrm{nM}) \alpha-$ FXIla (0 or $62.5 \mathrm{nM})$, thrombin $(2.5 \mathrm{nM})$ and $\mathrm{CaCl}_{2}(5 \mathrm{mM})$ in a final volume of $1 \mathrm{ml}$ were transferred into a vinyl tube and rotated at $30 \mathrm{rpm}$ for $90 \mathrm{~min}$ at room temperature. The formed clot was transferred into an eppendorf tube containing TPA (7.14 nM). Plasmin activity was measured with S-2251 and fluorescence release was measured at an excitation wavelength of $485 \mathrm{~nm}$, an emission wavelength of $438 \mathrm{~nm}$ and a cut-off value of $515 \mathrm{~nm}$. (A) Fluorescence release during clot formation; (B) Plasmin formation during clot formation; (C) Fluorescence release during fibrinolysis; (D) Plasmin formation during fibrinolysis $(n=3)$. Data points represent mean \pm range.

\section{Scanning electron microscopy}

Finally, we visualized clot formation and fibrinolysis using SEM. In the absence of tPA, $\alpha$-FXIla increased the density of the fibrin fibers (Figure 3.5A,B). This result shows that $\alpha-F X I l a$ increased the fiber density also in the presence of plasminogen. Furthermore, we added tPA during clot formation to initiate fibrinolysis. Figures 3.5C,D show that the pores in the fibrin network were more pronounced in the presence of $\alpha-F X I l a$ and IPA, compared to the same 
experimental conditions without the addition of $\alpha-F X I l a$. This indicates that in the presence of $\alpha$-FXIla more fibrinolysis had occurred.

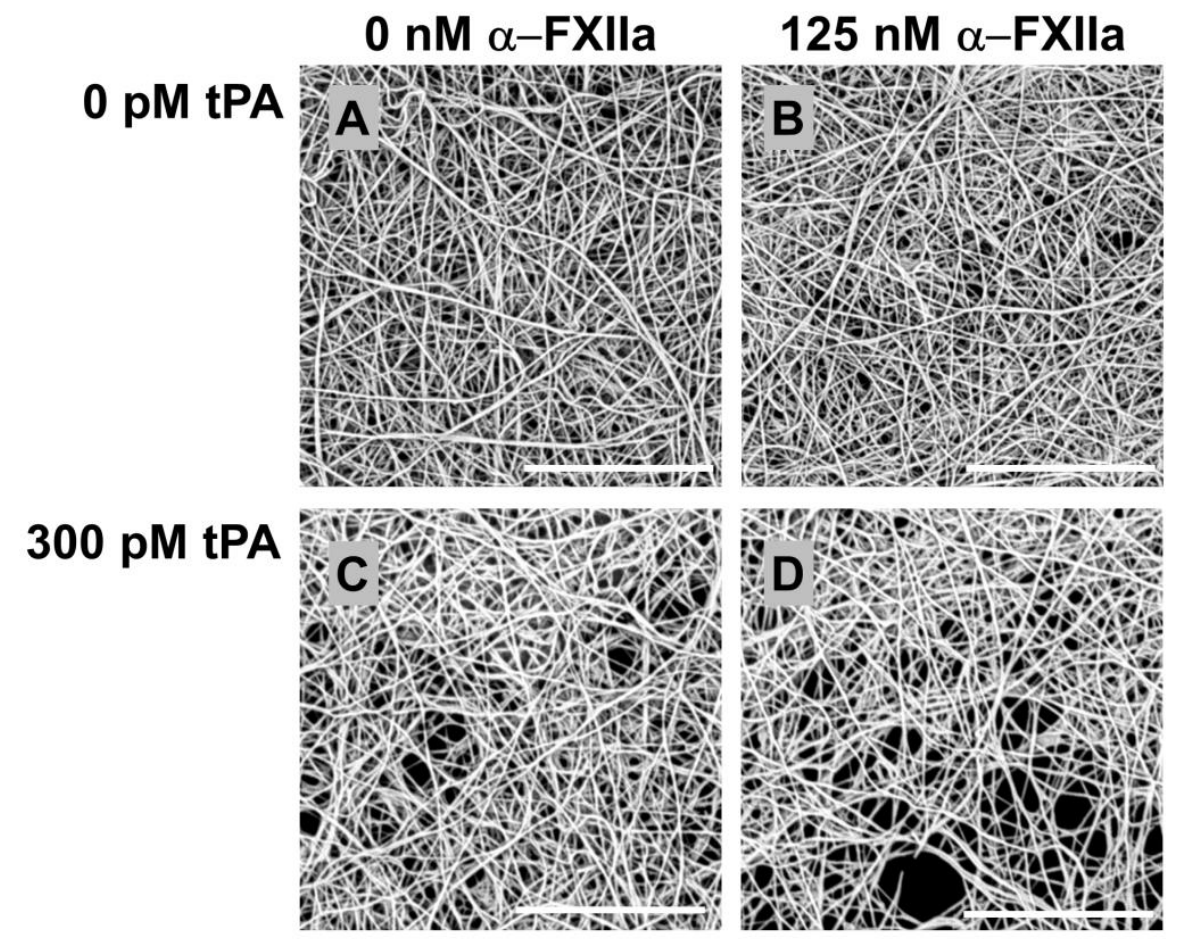

Figure 3.5. The effect of $\alpha-F X I l a$ on fibrin structure and fibrinolysis.

Representative SEM images of clots prepared from fibrinogen $(1 \mathrm{mg} / \mathrm{ml})$, plasminogen $(300 \mathrm{nM})$, thrombin $(0.5 \mathrm{nM})$ and $\mathrm{CaCl}_{2}(5 \mathrm{mM})$ during $30 \mathrm{~min}$ at room temperature. (A - B) Clots formed in the absence of tPA and in the absence (A) and presence (B) of $125 \mathrm{nM} \alpha-\mathrm{FXIla}$. (C - D) Clots formed in the presence of $300 \mathrm{pM}$ tPA in the absence (C) and presence $(D)$ of $125 \mathrm{nM} \alpha-F X I l a(n=3)$. Scale bar represent $6 \mu \mathrm{m}$ (magnification: 20.000X).

\section{Discussion}

FXIla is a protein with several functions, including activation of the coagulation cascade and the fibrinolytic system. Several clinical studies observed a relation between levels of FXII and arterial thrombosis, but the results are ambiguous. Reduced as well as elevated levels of FXII, FXIla or FXIla-C1-esterase inhibitor complexes have been associated with an increased risk of thrombosis [15-17]. However, other studies did not find an association between FXII(a) levels and arterial thrombosis $[18,19]$. In vivo models showed that $\mathrm{FXII}^{-/ 2}$ were protected from experimentally induced thrombus formation [20]. However, humans deficient in FXII do not seem to be protected from thrombosis nor do they have 


\section{Chapter 3}

a bleeding tendency [21]. In vivo experiments in baboons and in humans showed that the activation of the fibrinolytic system is partly dependent on the activity of FXII [22,23]. These studies show a role for FXII in both thrombus formation and fibrinolysis in vivo.

In this paper we investigated the two activities of $\alpha-F X I l a$ in fibrin formation and fibrin degradation. We have shown that $\alpha$-FXIla is able to convert plasminogen into plasmin and that this plasmin accelerated fibrinolysis in the presence of tPA. $\alpha$-FXIla decreased the clot lysis time in a concentration dependent manner. Simultaneous measurements of plasmin formation, showed that this reduction in lysis time was accompanied by a faster onset of plasmin generation. Furthermore, we observed that clots made in the presence of $\alpha$-FXIla under flow in a Chandler loop, lysed faster and produced more plasmin. Since these clots only lysed if plasminogen was present, the action of $\alpha$-FXIla on fibrinolysis was mediated via the formation of additional plasmin from plasminogen.

In vitro studies have shown that not only FXIla but also the other proteases of the contact system, kallikrein and FXla, are able to cleave plasminogen directly and hereby contribute to fibrinolysis [2,4]. Activation of plasminogen by IPA or $\mathrm{u}$-PA is several orders of magnitude faster than by enzymes of the contact system [5]. Nonetheless, FXIla was found to have a substantial contribution to plasminogen activation $[24,25]$. Braat et al found that in the dextran sulphate euglobulin fraction (DEF) of plasma, $20 \%$ of the plasminogen activator activity could be attributed to activity of FXIla [24]. Schousboe et al found that FXIla is an important contributor to plasmin generation, even though the ability of FXIla to generate plasmin from plasminogen is lower for a-FXIla than for UPA. This is due to the fact that the concentration of FXII is $10^{3}$ to $10^{4}$ times higher than the concentration of prourokinase [25].

The proteins of the fibrinolytic system and of the contact activation system have similar origins. Factor XII and tPA for example are homologous: particularly the epidermal growth factor and Kringle regions show a high degree of homology [26]. We have recently shown that FXII and $\alpha-F X I I$ bind with a high affinity to fibrin and fibrinogen [13]. This is in contrast to IPA and plasminogen, they only bind to fibrin with high affinity [27]. Therefore, in a solution that contains fibrinogen, $\alpha-F X I l a$ will bind to fibrinogen, whereas plasminogen will not. This could explain why a-FXIla was better able to convert plasminogen into plasmin in buffer than in a solution containing fibrinogen. However in the presence of fibrin, $\alpha-F X I l a$ and plasminogen both bind to the fibrin. The fibrin can serve as a 
surface on which the concentration of the substrate (plasminogen) and the enzyme ( $\alpha-F X I l a)$ is higher, resulting in more plasmin formation.

In the presence $\alpha-F X I l a$, fibrin fibers become thinner, are more densely arranged and the clot stiffness increases. In addition, activation of the intrinsic pathway of coagulation via a-FXIla leads to thrombin formation which also influences the clot structure [13]. Furthermore, recent data suggest that FXIla can directly activate prothrombin, independent of FXI activation [28]. In vivo, these actions of FXIla could help to stabilize the fibrin clot and prevent embolization. Thrombotic models in $\mathrm{FXII}^{-1-}$ mice, show that unstable thrombi are formed which embolize quickly, indicating that FXII is important for stable thrombus formation [20]. This is in agreement with our data from plasma and purified experiments which show that $\alpha-F X$ Ila increases clot stiffness [13]. In the current study, we provide new evidence for a role of FXII in the process of fibrinolysis using clots that were formed under the influence of both a-FXIla and tPA. We have dissected the conditions under which the effect of $\alpha$-FXIla on fibrinolysis was most obvious, i.e. under conditions of low tPA concentrations. While indeed we confirmed our earlier findings that $\alpha$-FXlla produced denser clots, our new data showed that the effect on the fibrinolytic system led to increased fibrinolysis rates, due to increased plasmin generation, despite the increased fiber density of the clots. Our data therefore showed that FXII plays a dual role in coagulation and fibrinolysis.

The action of $\alpha-F X I l a$ on fibrin structure and clot characteristics were exclusively found for $\alpha-F X I l a$ and not for $\beta$-FXIla [13]. Additionally, $\beta$-FXIla is not able to activate $F X I$ and therefore will not initiate coagulation [29]. However, $\alpha$-FXIla and $\beta$-FXIla are both able to convert plasminogen into plasmin [3]. We propose that first $\alpha-F X I l a$ strengthens the clot, both via the formation of additional thrombin and directly by interacting with fibrin(ogen). This action of FXIla prevents embolization of the recently formed thrombus [20]. During fibrinolysis, FXIla is able to activate plasminogen and may contribute to fibrinolysis from within the clot, when in the early stage of fibrinolysis only low levels of plasminogen activators are present. The fibrinolytic system is enhanced further after the activation of FXI and prekallikrein by FXIla. FXII and proteins of the fibrinolytic system also stimulate angiogenesis. Binding of FXII to the urokinase plasminogen activator receptor (UPAR) initiates angiogenesis via stimulation of ERK1/2 and Akt [30]. tPA and fibrin fragment E, a fibrin degradation product formed during fibrinolysis, enhance angiogenesis $[31,32]$. Therefore, even after clot formation and fibrinolysis, FXII and the proteins of the fibrinolytic system participate in the same processes. 


\section{Chapter 3}

The controversial results of the role of FXII(a) in arterial thrombosis in clinical studies, might be explained by the balance of counteracting effects of FXIla. Our results were obtained in purified systems, in the absence of physiological inhibitors, such as PAI-1 and a2-antiplasmin. Therefore, in our experiments fibrinolysis occurred immediately after fibrin formation starts. However, in vivo, fibrinolysis may be delayed by inhibitors until bleeding is stopped. Under pathologic conditions and depending on the time point in the tract of clot formation and fibrinolysis, FXIla will either be pro-thrombotic or pro-fibrinolytic.

In conclusion, we propose that FXIla first supports the formation of a stable thrombus. Subsequently, FXIla supports fibrinolysis by activating plasminogen when concentrations of IPA and UPA are still low. This could explain the ambiguous results found in clinical studies for the influence of FXII(a) in arterial thrombosis. To further unravel the two activities of FXIla in time, plasma-based and in vivo experiments are needed.

\section{Acknowledgments}

This work was funded by the Netherlands Heart Foundation (grant 2008B120). RASA and HP are supported by the British Heart Foundation (RG/13/3/30104 and SP/12/11/29786). 


\section{References}

1. Ponczek MB, Gailani D, Doolittle RF. Evolution of the contact phase of vertebrate blood coagulation. J Thromb Haemost. 2008; 6: 1876-83.

2. Colman RW. Activation of plasminogen by human plasma kallikrein. Biochem Biophys Res Commun. 1969; 35: 273-9.

3. Goldsmith GH, Jr., Saito H, Ratnoff OS. The activation of plasminogen by Hageman factor (Factor XII) and Hageman factor fragments. J Clin Invest. 1978; 62: 54-60.

4. Mandle RJ, Jr., Kaplan AP. Hageman-factor-dependent fibrinolysis: generation of fibrinolytic activity by the interaction of human activated factor $\mathrm{XI}$ and plasminogen. Blood. 1979; 54: 850-62.

5. Miles LA, Greengard JS, Griffin JH. A comparison of the abilities of plasma kallikrein, beta-Factor XIla, Factor Xla and urokinase to activate plasminogen. Thromb Res. 1983; 29: 407-17.

6. Rijken DC, Lijnen HR. New insights into the molecular mechanisms of the fibrinolytic system. J Thromb Haemost. 2009; 7: 4-13.

7. Sakharov DV, Plow EF, Rijken DC. On the mechanism of the antifibrinolytic activity of plasma carboxypeptidase B. J Biol Chem. 1997; 272: 14477-82.

8. Hoylaerts M, Rijken DC, Lijnen HR, Collen D. Kinetics of the activation of plasminogen by human tissue plasminogen activator. Role of fibrin. $\mathrm{J}$ Biol Chem. 1982; 257: 2912-9.

9. Weisel JW. Structure of fibrin: impact on clot stability. J Thromb Haemost. 2007; 5 Suppl 1: 116-24.

10. Longstaff C, Thelwell C, Williams SC, Silva MM, Szabo L, Kolev K. The interplay between tissue plasminogen activator domains and fibrin structures in the regulation of fibrinolysis: kinetic and microscopic studies. Blood. 2011; 117: 661-8.

11. Mutch NJ, Engel R, Uitte de Willige S, Philippou H, Ariens RA. Polyphosphate modifies the fibrin network and down-regulates fibrinolysis by attenuating binding of tPA and plasminogen to fibrin. Blood. 2010; 115: 3980-8.

12. Dunn EJ, Philippou H, Ariens RA, Grant PJ. Molecular mechanisms involved in the resistance of fibrin to clot lysis by plasmin in subjects with type 2 diabetes mellitus. Diabetologia. 2006; 49: 1071-80.

13. Konings J, Govers-Riemslag JW, Philippou H, Mutch NJ, Borissoff JI, Allan P, Mohan S, Tans G, Ten Cate H, Ariens RA. Factor Xlla regulates the structure of the fibrin clot independently of thrombin generation through direct interaction with fibrin. Blood. 2011; 118: 3942-51.

14. Mutch NJ, Moore NR, Mattsson C, Jonasson H, Green AR, Booth NA. The use of the Chandler loop to examine the interaction potential of NXY-059 on the thrombolytic properties of rtPA on human thrombi in vitro. Br J Pharmacol. 2008; 153: 124-31.

15. Cooper JA, Miller GJ, Bauer KA, Morrissey JH, Meade TW, Howarth DJ, Barzegar $\mathrm{S}$, Mitchell JP, Rosenberg RD. Comparison of novel hemostatic factors and conventional risk factors for prediction of coronary heart disease. Circulation. 2000; 102: 2816-22.

16. Doggen CJ, Rosendaal FR, Meijers JC. Levels of intrinsic coagulation factors and the risk of myocardial infarction among men: Opposite and synergistic effects of factors XI and XII. Blood. 2006; 108: 4045-51.

17. Govers-Riemslag JW, Smid M, Cooper JA, Bauer KA, Rosenberg RD, Hack CE, Hamulyak K, Spronk HM, Miller GJ, ten Cate H. The plasma kallikrein-kinin system and risk of cardiovascular disease in men. J Thromb Haemost. 2007; 5: 1896-903. 


\section{Chapter 3}

18. Lowe GD, Rumley A, McMahon AD, Ford I, O'Reilly DS, Packard CJ. Interleukin-6, fibrin D-dimer, and coagulation factors VII and XIla in prediction of coronary heart disease. Arterioscler Thromb Vasc Biol. 2004; 24: 1529-34.

19. Merlo C, Wuillemin WA, Redondo M, Furlan M, Sulzer I, Kremer-Hovinga J, Binder BR, Lammle B. Elevated levels of plasma prekallikrein, high molecular weight kininogen and factor XI in coronary heart disease. Atherosclerosis. 2002; 161: 2617.

20. Renne T, Pozgajova M, Gruner S, Schuh K, Pauer HU, Burfeind P, Gailani D, Nieswandt B. Defective thrombus formation in mice lacking coagulation factor XII. $J$ Exp Med. 2005; 202: 271-81.

21. Girolami A, Morello M, Girolami B, Lombardi AM, Bertolo C. Myocardial infarction and arterial thrombosis in severe (homozygous) FXII deficiency: no apparent causative relation. Clin Appl Thromb Hemost. 2005; 11: 49-53.

22. Jansen PM, Pixley RA, Brouwer M, de Jong IW, Chang AC, Hack CE, Taylor FB, Jr., Colman RW. Inhibition of factor XII in septic baboons attenuates the activation of complement and fibrinolytic systems and reduces the release of interleukin- 6 and neutrophil elastase. Blood. 1996; 87: 2337-44.

23. Levi M, Hack CE, de Boer JP, Brandjes DP, Buller HR, ten Cate JW. Reduction of contact activation related fibrinolytic activity in factor XII deficient patients. Further evidence for the role of the contact system in fibrinolysis in vivo. J Clin Invest. 1991; 88: 1155-60.

24. Braat EA, Dooijewaard G, Rijken DC. Fibrinolytic properties of activated FXII. European journal of biochemistry / FEBS. 1999; 263: 904-11.

25. Schousboe I, Feddersen K, Rojkjaer R. Factor XIla is a kinetically favorable plasminogen activator. Thrombosis and haemostasis. 1999; 82: 1041-6.

26. Cool DE, Edgell CJ, Louie GV, Zoller MJ, Brayer GD, MacGillivray RT. Characterization of human blood coagulation factor XII cDNA. Prediction of the primary structure of factor XII and the tertiary structure of beta-factor XIla. The Journal of biological chemistry. 1985; 260: 13666-76.

27. Medved L, Nieuwenhuizen W. Molecular mechanisms of initiation of fibrinolysis by fibrin. Thrombosis and haemostasis. 2003; 89: 409-19.

28. Puy C, Tucker EI, Wong ZC, Gailani D, Smith SA, Choi SH, Morrissey JH, Gruber A, McCarty OJ. Factor XII promotes blood coagulation independent of factor XI in the presence of long chain polyphosphate. J Thromb Haemost. 2013.

29. Revak SD, Cochrane CG, Bouma BN, Griffin JH. Surface and fluid phase activities of two forms of activated Hageman factor produced during contact activation of plasma. J Exp Med. 1978; 147: 719-29.

30. LaRusch GA, Mahdi F, Shariat-Madar Z, Adams G, Sitrin RG, Zhang WM, McCrae $\mathrm{KR}$, Schmaier AH. Factor XII stimulates ERK1/2 and Akt through uPAR, integrins, and the EGFR to initiate angiogenesis. Blood. 2010; 115: 5111-20.

31. Caiado F, Carvalho T, Silva F, Castro C, Clode N, Dye JF, Dias S. The role of fibrin $\mathrm{E}$ on the modulation of endothelial progenitors adhesion, differentiation and angiogenic growth factor production and the promotion of wound healing. Biomaterials. 2011; 32: 7096-105.

32. Bootle-Wilbraham CA, Tazzyman S, Thompson WD, Stirk CM, Lewis CE. Fibrin fragment $E$ stimulates the proliferation, migration and differentiation of human microvascular endothelial cells in vitro. Angiogenesis. 2001; 4: 269-75. 


\section{Chapter 4}

Inhibition of activated FXII reduces clot strength, a preliminary report

J. Konings, H. Ghafouri, Y.M. Henskens, H. ten Cate, J.W.P. Govers-Riemslag 



\section{Introduction}

Several anticoagulant drugs are used in clinical practice nowadays. However, the main side effect of these drugs is the increased risk of bleeding. In 2005, it was found by Renné et al that mice deficient in coagulation factor XII (FXII) are protected from experimentally induced thrombosis without having a bleeding phenotype [1]. Humans deficient in FXII do not have a bleeding tendency either. Furthermore, elevated levels of activated FXII (FXIla) have been observed in patients with coronary heart disease (CHD) and myocardial infarction (MI) [2-7]. Due to these observations, targeting FXIla has emerged as a potentially safe method to prevent thrombosis.

Several FXIla-inhibitors have been tested in animal models for their efficacy in preventing thrombosis. rHA-Infestin-4 is a serine protease inhibitor which was able to prevent experimentally induced arterial thrombus formation in mice and rats, and protected mice from ischemic brain injury and silent brain ischemia $[8,9]$. Ixodes ricinus contact phase inhibitor (Ir-CPI) binds with high affinity to FXIla, FXla and kallikrein and inhibits their enzymatic activity. Mice treated with Ir-CPI were protected from induced venous and arterial thrombosis [10]. However, both rHA-Infestin-4 and Ir-CPI moderately inhibit fibrinolysis, which is theoretically unwanted since reduced fibrinolysis in itself is a risk factor for thrombosis $[8,11]$.

We tested the effect of a specific monoclonal antibody (mAb) directed towards human FXIla (anti-FXIla mAb) on thrombus formation, clot formation and fibrinolysis in whole blood and in platelet poor plasma (PPP) deficient in FXII using turbidimetric assays and rotational thromboelastometry (ROTEM) experiments.

\section{Materials and methods}

\section{Materials}

Congenital FXII-deficient plasma ( $<1 \%$ FXII activity) was from George King Biomedical (St Overland Park, KS, USA). Sulfatides were from Sigma. Purified FXII was from Enzyme Research Laboratories (Swansea, UK). Recombinant tissue type-plasminogen activator (t-PA) was from Boehringer Ingelheim (Alkmaar, the Netherlands). Synthetic phospholipids DOPS, DOPC, DOPE (1,2-dioleoyl-snglycero-3-phosphoserine, 1,2-dioeoyl-sn-glycero-3-phosphocholine, 1,2dioleoyl-snglycero-3-phosphoethanolamine) were from Avanti Polar lipids Inc (Alabaster, AL) and were prepared by sonication as described earlier 
(DOPS/DOPC/DOPE, 20/60/20, $\mathrm{mol} / \mathrm{mol} / \mathrm{mol}$ ) [12]. In-tem, ex-tem and star-tem reagents were from TEM International (Munich, Germany). The monoclonal antibody directed to human FXIla (anti-FXIla mAb) 3F7 was provided by CSL Behring GmbH (Marburg, Germany).

\section{Blood drawing}

Blood samples were drawn from 3 healthy individuals and were collected in $3.2 \%$ sodium citrate as anticoagulant. The first collection tube was discarded. Immediately upon blood drawing ROTEM experiments were started. All 3 healthy volunteers gave written informed consent that blood and plasma could be used for research purposes. The study was approved by the local institutional Ethics Committee and was conducted according to the principles of the Declaration of Helsinki.

\section{Turbidity measurements}

Fibrin clot formation and fibrinolysis were monitored in low binding polystyrene 96-well plates (Greiner, Frickenhauser, Germany) by the change in turbidity at $405 \mathrm{~nm}\left(\mathrm{~A}_{405}\right)$ every $15 \mathrm{~s}$, for 1.5 hours at $37^{\circ} \mathrm{C}$ using a ELx808 plate reader (Biotek Instruments, Winooski, VT).

To congenital FXII-deficient plasma, purified FXII (0 - 100\%; normal FXII concentration: $375 \mathrm{nM}$ [13]) and anti-FXIla $\mathrm{mAb}(20 \mu \mathrm{g} / \mathrm{ml})$ or an equal volume of phosphate buffered saline (PBS) buffer were added. The final volume of plasma was $80 \%$. Coagulation was initiated with $10 \mu \mathrm{M}$ sulfatides (an activator of FXII), $16 \mathrm{mM} \mathrm{CaCl}_{2}$ and $4 \mu \mathrm{M}$ phospholipid vesicles. To monitor fibrinolysis, $0.1 \mu \mathrm{g} / \mathrm{ml}$ tPA was added to the clotting mixture. Clot lysis time was calculated as the time from $50 \%$ clot formation to $50 \%$ clot lysis.

\section{$\underline{\text { ROTEM }}$}

Thrombus formation was determined with rotational thromboelastometry (ROTEM) via the change of elasticity during thrombus formation using standard assays in a TEM thromboelastometer (TEM International, Munich, Germany) according to the manufacturer's instructions. In a cuvette with a rotating cylindrical pin ROTEM experiments were performed with commercially available reagents in human whole blood using different ROTEM tests. Freshly obtained, citrate-anticoagulated human whole blood $(300 \mu \mathrm{l})$ to which different amounts of anti-FXIla mAb $(0-100 \mu \mathrm{g} / \mathrm{ml})$ or an equal volume of phosphate buffered saline (PBS)-buffer was added was activated with a combination of $20 \mu \mathrm{l}$ Star-tem $\left(\mathrm{CaCl}_{2}\right)$ and $20 \mu \mathrm{l}$ In-tem (ellagic acid) or $20 \mu \mathrm{l}$ Star-tem and $20 \mu \mathrm{l}$ Ex-tem (tissue factor (TF)). To measure clot lysis time, tPA was added to the premix of 
star-tem with in-tem or ex-tem reagent. The final concentration of tPA $(0.2 \%$ of the total volume) was $0.16 \mu \mathrm{g} / \mathrm{ml}$.

Evaluation parameters of the curves used were the clotting time (CT), maximum clot firmness (MCF) and maximum rate of clot formation ( $\alpha$-angle). The two latter inform on the maximum elastic clot strength and the rate of fibrin strand formation, respectively [14]. The clot lysis time from 50\% clot formation to $50 \%$ clot lysis was calculated from the raw data.

\section{Statistical analysis}

Data are expressed as median and range. Statistical analyses were performed with PRISM for Windows, version 5.0 (GraphPad Software, San Diego, CA, USA) using one-way analysis of variance (ANOVA), Bonferroni for post hoc comparison, or $t$ test (GraphPad Software) when appropriate, and $p<0.05$ was considered statistically significant.

\section{Results and discussion}

We tested the effects of anti-FXIla mAb directed towards human FXIla on clot formation and fibrinolysis with ROTEM and with turbidity assays. ROTEM experiments were performed in whole blood, to which we added different concentrations of the mAb. In the turbidity experiments we used purchased PPP from a patient with a congenital FXII-deficiency and at a fixed concentration of $20 \mu \mathrm{g} / \mathrm{ml} \mathrm{mAb}$ added several concentrations of purified FXII.

Table 1 shows the results of the ROTEM experiments in whole blood of 3 healthy donors to which varying amounts of anti-FXIla mAb $(0-25-50$ and $100 \mu \mathrm{g} / \mathrm{ml}$ ) were added. ROTEM assays using INTEM and EXTEM reagents were measured. The INTEM assay showed an increase in CT with increasing amounts of anti-FXIla mAb indicating that the mAb concentration-dependently inhibited activated FXII (FXIla) formed by the INTEM reagent. The MCF and $\alpha$-angle were significantly reduced at $100 \mu \mathrm{g} / \mathrm{ml}$ of anti-FXIla mAb compared to no addition, which most likely resulted from FXIla inhibition. Upon addition of tPA, the CLT was significantly increased at $100 \mu \mathrm{g} / \mathrm{ml}$ anti-FXlla mAb compared to $25 \mu \mathrm{g} / \mathrm{ml}$ anti-FXIla mAb $(p=0.01)$. In the EXTEM assay, only $100 \mu \mathrm{g} / \mathrm{ml}$ of anti-FXIla $m A b$ was tested and it was observed that the CLT was significantly increased at $100 \mu \mathrm{g} / \mathrm{ml}$ anti-FXIla mAb compared to no mAb $(p=0.04)$. The CT, MCF and $\alpha$-angle were not affected by the mAb in the EXTEM assay. 


\section{Chapter 4}

Table 4.1: ROTEM analysis using in-tem and ex-tem reagents in citrated whole blood of 3 healthy donors. To the blood, an ascending amount of $0-25-50$ and $100 \mu \mathrm{g} / \mathrm{ml}$ anti-FXIla mAb was added. The data are expressed as median and range.

\begin{tabular}{l|llll|ll}
\hline $\begin{array}{l}\text { anti-FXIla mAb } \\
(\mu \mathrm{g} / \mathrm{ml})\end{array}$ & 0 & 25 & 50 & 100 & 0 & 100 \\
\hline $\mathbf{C T}(\mathbf{s})$ & 3.2 & 5.0 & 6.5 & 8.0 & 0.8 & 0.9 \\
$\mathbf{M C F}(\mathbf{m m})$ & {$[2.6-3.2]$} & {$[4.6-5.4]$} & {$[5.7-6.5]$} & {$[6.3-8.5]$} & {$[0.8-0.9]$} & {$[0.8-1.5]$} \\
$\boldsymbol{\alpha}$ angle $\left(^{\circ}\right)$ & $76[63-69]$ & $62[59-64]$ & $63[59-63]$ & $57[56-59]$ & $64[61-64]$ & $63[63-65]$ \\
$\mathbf{C L T}(\mathbf{s})$ & 17.9 & $74[68-74]$ & $71[63-73]$ & $64[57-70]$ & $75[71-75]$ & $74[72-75]$ \\
\hline
\end{tabular}

Next, we determined clot formation and fibrinolysis in FXII-deficient plasma in a turbidity assay to which we added different amounts of purified FXII to obtain $0-5-50-100 \%$ FXII of normal plasma concentration. Figure $1 \mathrm{~A}$ shows that in the presence of $20 \mu \mathrm{g} / \mathrm{ml}$ anti-FXIla mAb, (optimal concentration to perform this experiment determined with a titration curve, data not shown) the lag time before measurable fibrin formation was significantly increased at $50 \%$ and $100 \%$ FXII compared to the absence of anti-FXIla mAb at the same respective FXII concentration ( $p=0.013$ and $p<0.001$, respectively). In Figure $1 B$, the maximal absorbance was significantly increased $(p<0.001)$ at $100 \%$ FXII in the presence of $20 \mu \mathrm{g} / \mathrm{ml} \mathrm{mAb}$ compared to no inhibition of FXIla and was comparable to the maximal absorbance measured in FXII-deficient plasma to which we did not add purified FXII or anti-FXIla mAb. An increased maximal absorbance is associated with a clot consisting of thicker fibers and a less dense structure. Figure 1C shows that at $100 \%$ FXII the CLT was decreased in the presence of the anti-FXIla mAb compared to the absence of the anti-FXIla $m A b(p=0.001)$. This indicates that the clot formed when FXlla was inhibited, lysed faster than the clot formed without inhibition of FXIla. 

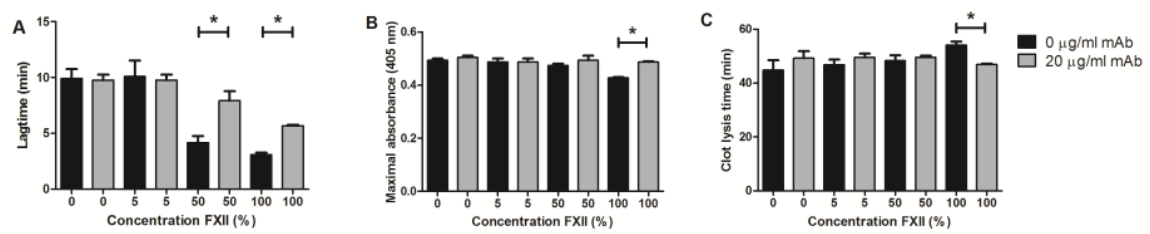

Figure 4.1: The effect of anti-FXIla mAb on the lag time, maximal absorbance and clot lysis time at different FXII-concentrations.

FXII-deficient plasma (final volume $=80 \%$ ) was reconstituted with purified FXII $(0 \%-5 \%$ - $50 \%-100 \%$ of normal plasma concentration) and to the plasma either $20 \mu \mathrm{g} / \mathrm{ml}$ antiFXIla monoclonal antibody ( $\mathrm{mAb}$ ) or an equal volume of phosphate buffered saline (PBS) buffer was added. Clotting was initiated via contact activation with $10 \mu \mathrm{M}$ sulfatides, $4 \mu \mathrm{M}$ phospholipid vesicles and $16 \mathrm{mM} \mathrm{CaCl}_{2}$. Turbidity was monitored every $15 \mathrm{~s}$ at $405 \mathrm{~nm}$ at $37^{\circ} \mathrm{C}$. Figure shows the median \pm range of three measurements. From the turbidity curves, (A) the lag time, (B) maximal absorbance at $405 \mathrm{~nm}$ and (C) clot lysis time were determined. * $p<0.05$

These results indicate that the anti-FXIla mAb inhibited clotting in a concentration-dependent manner, when clotting was initiated via FXII activation. Furthermore, in the presence of the anti-FXIla mAb the firmness of the clot was decreased and the fibrin fibers were thicker. In the ROTEM experiments at 100 $\mu \mathrm{g} / \mathrm{ml}$ of anti-FXIla mAb, the MCF and maximum rate of clot formation ( $\alpha$-angle) were reduced, indicating that a weaker clot was formed. In the turbidity experiments, we observed that the anti-FXIla mAb increased the maximal absorbance indicating thicker fibrin fibers and a looser clot. The anti-FXIla mAb reduced the CLT in the turbidity experiments, whereas it increased the CLT in the ROTEM experiments. Possibly this is due to the difference in concentration of anti-FXIla mAb used: the CLT in the ROTEM experiments was only increased at the highest concentrations of anti-FXIla mAb. At $25 \mu \mathrm{g} / \mathrm{ml}$ antiFXIla mAb, no effect on the CLT was observed in the ROTEM experiments. In the turbidity experiments, $20 \mu \mathrm{g} / \mathrm{ml}$ of anti-FXIla mAb reduced CLT at $100 \%$ FXII, probably because the clot was weaker due to the inhibition of FXII. At lower FXII concentrations, CLT was not influenced by the anti-FXIla mAb.

Compared to the other FXIla-inhibitors rHA-Infestin-4 [8,9] and Ir-CPI [10], antiFXIla mAb had little influence on fibrinolysis. Inhibiting FXIla will also inhibit its profibrinolytic effects: FXIla is able to stimulate fibrinolysis by converting plasminogen into plasmin. However, also in the EXTEM assay the clot lysis time was increased at $100 \mu \mathrm{g} / \mathrm{ml}$ anti-FXIla mAb. This indicates that the mAb potentially inhibits fibrinolysis at this concentration independent of the inhibition of FXIla. However, in our experiments FXII was activated with either sulfatides or INTEM reagents, both potent FXII activators, leading to much higher 


\section{Chapter 4}

concentrations of activated FXII than those observed in in vivo situations. Therefore, to inhibit FXIla in vivo lower levels of anti-FXIla mAb will suffice.

In conclusion, anti-FXIla mAb was able to inhibit clotting via FXII activation in a concentration dependent manner. The clots formed in the presence of anti-FXIla mAb were less firm and composed of thicker fibers. The effect of anti-FXIla mAb on fibrinolysis was minimal. However, we only tested a limited number of healthy individuals and only determined clot formation and fibrinolysis. Additional in vitro experiments and in vivo experiments in animal models are required in order to better characterize the relevance of modifying fibrin clot formation through FXIla inhibition, prior to clinical testing.

\section{Acknowledgements}

This work was supported by the Netherlands Heart Foundation (grant 2008B120). The monoclonal antibody anti-FXIla mAb, purified FXII and FXIIdeficient plasma were provided by CSL Behring GmbH, Germany (Prof. Dr. G. Dickneite, Dr. F. May and Dr. M. Nolte). 


\section{References}

1. Renne T, Pozgajova M, Gruner S, Schuh K, Pauer HU, Burfeind P, Gailani D, Nieswandt B. Defective thrombus formation in mice lacking coagulation factor XII. $J$ Exp Med. 2005; 202: 271-81.

2. Cooper JA, Miller GJ, Bauer KA, Morrissey JH, Meade TW, Howarth DJ, Barzegar $\mathrm{S}$, Mitchell JP, Rosenberg RD. Comparison of novel hemostatic factors and conventional risk factors for prediction of coronary heart disease. Circulation. 2000; 102: 2816-22.

3. Miller GJ, Esnouf MP, Burgess AI, Cooper JA, Mitchell JP. Risk of coronary heart disease and activation of factor XII in middle-aged men. Arterioscler Thromb Vasc Biol. 1997; 17: 2103-6.

4. Zito F, Drummond F, Bujac SR, Esnouf MP, Morrissey JH, Humphries SE, Miller GJ. Epidemiological and genetic associations of activated factor XII concentration with factor VII activity, fibrinopeptide A concentration, and risk of coronary heart disease in men. Circulation. 2000; 102: 2058-62.

5. Kohler HP, Carter AM, Stickland MH, Grant PJ. Levels of activated FXII in survivors of myocardial infarction--association with circulating risk factors and extent of coronary artery disease. Thromb Haemost. 1998; 79: 14-8.

6. Grundt H, Nilsen DW, Hetland O, Valente E, Fagertun HE. Activated factor 12 (FXIla) predicts recurrent coronary events after an acute myocardial infarction. Am Heart J. 2004; 147: 260-6.

7. Colhoun HM, Zito F, Norman Chan N, Rubens MB, Fuller JH, Humphries SE. Activated factor XII levels and factor XII 46C $>$ T genotype in relation to coronary artery calcification in patients with type 1 diabetes and healthy subjects. Atherosclerosis. 2002; 163: 363-9.

8. Hagedorn I, Schmidbauer S, Pleines I, Kleinschnitz C, Kronthaler U, Stoll G, Dickneite G, Nieswandt B. Factor XIla inhibitor recombinant human albumin Infestin-4 abolishes occlusive arterial thrombus formation without affecting bleeding. Circulation. 2010; 121: 1510-7.

9. Chen JW, Figueiredo JL, Wojtkiewicz GR, Siegel C, Iwamoto Y, Kim DE, Nolte MW, Dickneite G, Weissleder R, Nahrendorf M. Selective factor XIla inhibition attenuates silent brain ischemia: application of molecular imaging targeting coagulation pathway. JACC Cardiovascular imaging. 2012; 5: 1127-38.

10. Decrem Y, Rath G, Blasioli V, Cauchie P, Robert S, Beaufays J, Frere JM, Feron O, Dogne JM, Dessy C, Vanhamme L, Godfroid E. Ir-CPI, a coagulation contact phase inhibitor from the tick Ixodes ricinus, inhibits thrombus formation without impairing hemostasis. J Exp Med. 2009; 206: 2381-95.

11. Meltzer ME, Doggen CJ, de Groot PG, Rosendaal FR, Lisman T. The impact of the fibrinolytic system on the risk of venous and arterial thrombosis. Semin Thromb Hemost. 2009; 35: 468-77.

12. Govers-Riemslag JW, Janssen MP, Zwaal RF, Rosing J. Effect of membrane fluidity and fatty acid composition on the prothrombin-converting activity of phospholipid vesicles. Biochemistry. 1992; 31: 10000-8.

13. Reddigari SR, Shibayama Y, Brunnee T, Kaplan AP. Human Hageman factor (factor XII) and high molecular weight kininogen compete for the same binding site on human umbilical vein endothelial cells. J Biol Chem. 1993; 268: 11982-7.

14. MacDonald SG, Luddington RJ. Critical factors contributing to the thromboelastography trace. Seminars in thrombosis and hemostasis. 2010; 36: 712-22. 



\section{Chapter 5}

\section{Activation of the contact system in patients with a first acute myocardial infarction}

J. Konings, J.W.P. Govers-Riemslag, H.M.H. Spronk, J.L. Waltenberger, H. ten Cate

This research was originally published in Thrombosis Research. 2013; 132:13842. (c) Elsevier. 


\section{Chapter 5}

\section{Abstract}

Introduction: The contribution of the contact system to arterial thrombosis is unclear, results of clinical studies are conflicting. Particularly, little is known about the involvement of the contact system in the progression of arterial thrombosis. Therefore, we investigated the activation of the contact system during an acute myocardial infarction (AMI) and 3 and 6 months following the acute event.

Methods: Plasma of patients with a first AMI was collected on admission and 3 and 6 months after the AMI. The levels of complexes of activated factor XI (FXla), FXIla and kallikrein with C1-esterase inhibitor $(\mathrm{C} 1 \mathrm{INH})$ and the levels of complexes of FXla with $\alpha_{1}$-antitrypsin (AT) were measured in these plasmas. Recurrent cardiovascular events were recorded during a one year period after the AMI.

Results: We observed that the levels of FXla-C1INH were elevated during the acute phase compared to the steady-phase 3 and 6 months after the AMI. The levels of FXla-AT, FXIla-C1INH and kallikrein-C1INH did not change over time. The levels of FXla-C1INH, FXla-AT, FXIla-C1INH and kallikrein-C1INH were not predictive for a recurrent event.

Conclusion: We observed that during an AMI, the activation of FXI was increased. The levels of FXIla-C1INH were not elevated, suggesting that activation of FXI during the acute phase did not result from contact activation. The levels of the enzyme inhibitor complexes were not predictive for a recurrent event one year after the first AMI. 


\section{Introduction}

Acute myocardial infarction (AMI) is a major cause of morbidity and mortality worldwide. It is the result of partial or complete occlusion of the coronary arteries due to coronary thrombus formation, impairing myocardial blood supply. A hypercoagulable state, characterized by activation of the coagulation system, is detectable in patients with AMI [1-3]. Furthermore, within atherosclerotic lesions, coagulation factors, including contact factor components, are abundantly present [4]. This way, hypercoagulability in blood and in atherosclerotic lesions may have impact on the course of atherosclerosis as well as the risk of atherothrombotic complications.

The role of the contact activation system of coagulation in the development and progression of coronary artery disease (CAD) is still unclear. In animal studies, deficiency in coagulation factor XI (FXI) or FXII is associated with a decreased risk for arterial thrombosis, however, the results from clinical studies are not straightforward. Several studies found that high levels of FXI or activated FXI (FXla) are associated with an increased risk of CAD [2,5,6], however, in studies focussing only on women this association is less clear [7-9]. Furthermore, FXI deficiency does not protect against AMI [10]. The association between FXII and $C A D$ is complex, with a different association depending on whether zymogen or enzyme levels were measured. Low levels of FXII were found to be a risk factor for AMI, coronary heart disease (CHD) and all-cause mortality $[5,11,12]$, high levels of FXIla and low levels of FXIla in complex with its main natural inhibitor $\mathrm{C} 1$-esterase inhibitor $(\mathrm{FXIla}-\mathrm{C} 1 \mathrm{INH})$ were associated with an increased risk of $\mathrm{CHD}$ [13-18]. However, other studies that measured FXII, FXIla or FXIIa-C1INH did not confirm an association with $\mathrm{CHD}[6,8,12,19,20]$. In all these studies the levels of FXI or FXII were measured at one single time point. We set up a study to determine the activation of the contact system during the acute phase as well as during follow-up in patients with a first $\mathrm{AMI}$ and used these data to determine whether contact activation could be used as a marker for the occurrence of a recurrent thrombotic event.

\section{Materials and methods}

Study design

The study design has been described previously [21]. Consecutive patients with a first AMI were included. Patients were included if they met the following inclusion criteria: chest pain lasting longer than 30 min but not exceeding $24 \mathrm{~h}$, 


\section{Chapter 5}

ST-segment elevation $>1 \mathrm{~mm}$ on electrocardiography and biochemical evidence of myocardial necrosis. Exclusion criteria were a history of AMI or stroke and present use of oral anticoagulants. Blood samples were drawn on admission and before administration of low-molecular-weight-heparin (LMWH) or any other intervention and repeated after 3 months and 6 months. To rule out the use of LMWH before blood sampling, anti-Xa levels were determined in all baseline samples. Only samples with undetectable anti-Xa $(\leq 0.05 \mathrm{U} / \mathrm{ml})$ were considered to be free of LMWH and only these samples were included in the analysis.

The clinical outcome was recorded 3 months, 6 months and 12 months after inclusion. The combined end point comprised cardiovascular death, recurrent $\mathrm{MI}$, a second coronary intervention [percutaneous coronary intervention $(\mathrm{PCl})$ or coronary artery bypass grafting (CABG)] and ischemic stroke. The study protocol was approved by the Medical Ethics Review Committee of the Maastricht University Medical Center, The Netherlands. All patients gave written informed consent. Venous blood was collected in $10 \mathrm{mM}$ EDTA containing 100 $\mu \mathrm{g} / \mathrm{ml}$ soybean trypsin inhibitor (STI) and $20 \mathrm{mM}$ benzamidine for the measurement of enzyme inhibitory complexes and in $3.2 \%(\mathrm{w} / \mathrm{v})$ citrated tubes for other measurements.

\section{Assays}

The levels of FXla, FXIla and kallikrein in complex with $\mathrm{C} 1$-esterase inhibitor $(\mathrm{C} 1 \mathrm{INH})$ and $\mathrm{FXla}$ in complex with $\alpha_{1}$-antitrypsin (FXla-C1INH, FXIla-C1INH, kallikrein-C1INH and FXla-AT) were measured in plasma with enzyme-linked immunosorbent assays (ELISAs), as described previously [18]. The detection limits were 0.03 arbitrary units (A.U.) for all assays and values below the detection limit were set at 0.03 A.U. The inter- and intra-assay coefficient variations (CVs) of these assays have been published [18].

The levels of FXIc and FXIlc were determined by one-stage aPTT-based clotting assays, performed on a Sysmex CA-7000 Automated Coagulation Analyzer with reagents obtained from Dade Behring (Liederbach, Germany) and calibrated to WHO standards. D-dimer measurements in platelet-poor plasma were performed using the Ddimer Plus test (Dade Behring Inc., Liederbach, Germany) according to the manufacturer's instructions. Prothrombin fragment 1.2 (F1.2) was quantified by ELISA according to the manufacturer's instructions (Dade Behring Inc.). Anti-Xa activity was determined using the Coamatic Heparin test (Instrumentation Laboratory, Breda, The Netherlands). 
Statistical analysis

The data are expressed as median [interquartile range (IQR)] or as mean (standard deviation (SD)). Differences between two groups were analyzed using the Mann-Whitney $U$ test (levels of inhibitory complexes, D-dimer and F1.2) or the Student's t-test (levels of FXIc and FXIlc), depending on distribution characteristics. Correlations between the enzyme inhibitory complexes were determined using Spearman's rho correlation. The difference in the levels of the inhibitory complexes between the different time points was determined by the Friedman test, followed by the Dunn's multiple comparison test. The association between dichotomized levels of enzyme inhibitory complexes and outcome was assessed using Pearson chi-square test, and expressed as corresponding odds ratios (ORs) and 95\% confidence intervals (Cls). Results were viewed to be statistically significantly different at $p<0.05$. Statistical analyses were performed using IBM SPSS Statistics 20 for Windows (Armonk, New York: IBM Corp.) and Prism for Windows 5.00 (GraphPad Software Inc., San Diego, CA, USA).

\section{Results}

Of the 135 patients included in this clinical study, plasma samples of 89 patients on admission were available for the measurement of enzyme inhibitory complexes. In total, 16 patients were excluded because anti-Xa levels were $>0.05 \mathrm{U} / \mathrm{ml}$. Of 30 patients, the availability of plasma was not sufficient to perform analyses. The baseline characteristics of these 89 patients are represented in Table 5.1. Fourteen patients had a recurrent cardiovascular event during the follow-up period of 1 year. The levels of the enzyme inhibitory complexes on admission did not differ between patients stratified for gender, smoking, the presence of hypertension, diabetes mellitus or hypercholesterolemia and did not correlate with age.

Table 5.1: Baseline characteristics of the study population

\begin{tabular}{lccc}
\hline & Total group & Male & Female \\
\hline $\mathbf{N}(\%)$ & $89(100 \%)$ & $66(74 \%)$ & $23(26 \%)$ \\
Age, years (range) & $61(34-88)$ & $60(39-83)$ & $66(34-88)$ \\
Hypertension, $\mathbf{n}(\%)$ & $23(25.8 \%)$ & $18(27.3 \%)$ & $5(21.7 \%)$ \\
Smoking, $\mathbf{n}(\%)$ & $5(5.6 \%)$ & $3(4.5 \%)$ & $2(8.7 \%)$ \\
Type 2 diabetes, $\mathbf{n}(\%)$ & $47(52.8 \%)$ & $33(50.0 \%)$ & $14(60.9 \%)$ \\
Hypercholesterolemia, $\mathbf{n}(\%)$ & $18(20.2 \%)$ & $14(21.2 \%)$ & $4(17.4 \%)$ \\
\hline
\end{tabular}


Enzyme-inhibitory complexes

From 70 patients, complete sets of plasma samples from the three time points (on admission and at 3 months and 6 months after the acute event) were available to measure the levels of the enzyme inhibitory complexes. Figure 5.1 shows the levels of the enzyme inhibitory complexes on admission and during the follow-up period. For most patients, the levels of FXla-C1INH were highest on admission and declined during follow-up. There was a statistically significant reduction in $\mathrm{FXla}-\mathrm{C} 1 \mathrm{INH}$ complex levels with $55.7 \%$ of the patients at 3 months and $70 \%$ at 6 months showing a decline in this inhibitor complex compared with levels on admission. The median level of FXla-C1INH declined by $7.2 \%$ [IQR: $-19.9 \%-25.9 \%$ ] and $9.5 \%$ [IQR: $-7.1 \%-22.1 \%$ ] at 3 and 6 months, respectively. The levels of FXIa-AT, FXIla-C1INH and kallikrein-C1INH did not change significantly over time.
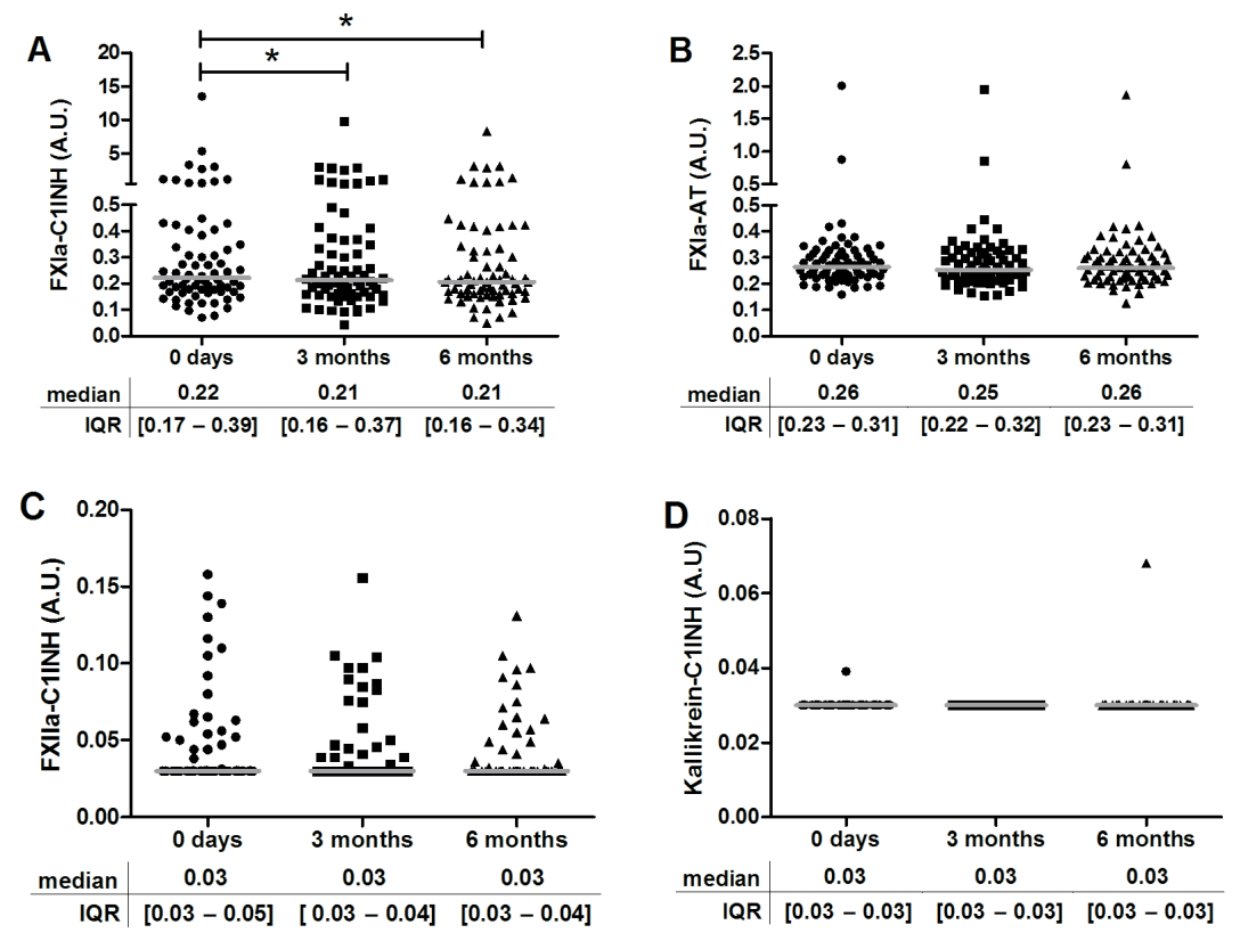

Figure 5.1: Levels of FXla-C1INH (A), FXla-AT (B), FXIla-C1INH (C) and kallikreinC1INH (D) of patients after a first myocardial infarction.

Levels of activated factor XI (FXla), FXIla and kallikrein in complex with C1-esterase inhibitor $(\mathrm{C} 1 \mathrm{INH})$ and $\mathrm{FXla}$ in complex with $\alpha_{1}$-antitrypsin (AT) were measured in patients with a first acute myocardial infarction (AMI) on admission ( 0 days) and 3 and 6 months after the AMI. Differences between the groups were determined by Friedman test for repeated measures. The grey line depicts the median value. ${ }^{*} \mathrm{P}<0.05$. IQR: interquartile range 
Because of the wide distribution of the data we were interested to determine the correlation for each enzyme-inhibitor complex, comparing different time points. The levels of FXla-C1INH on admission, correlated well with the levels at 3 months and at 6 months (Spearman's rho: 0.84 and $0.88 p<0.001$, respectively). The same was true for the levels of FXIla-C1INH (Spearman's rho: 0.77 and $0.87 p<0.001$, respectively) and FXla-AT (Spearman's rho: 0.76 and $0.77 p<0.001$, respectively). Since only few samples had levels above the detection limit for kallikrein-C1INH, we did not perform correlation analyses for this enzyme inhibitor complex. These high correlations indicate that patients with relatively high or low level of an enzyme inhibitor complex at one time point, will most likely remain relatively high or low at a later time point.

\section{$\underline{\text { Recurrent events }}$}

Table 5.2 shows the differences in the levels of FXIc, FXIIc, D-dimer, F1.2 and the enzyme inhibitory complexes on admission between patients that developed a recurrent event during follow-up and those that did not. The levels of D-dimer and F1.2 were higher in the patients that had a recurrent event during follow-up. The levels of the other factors did not differ between the groups. Figure 5.2 shows the distribution of FXla-C1INH, FXla-AT, FXIla-C1INH and kallikrein$\mathrm{C} 1 \mathrm{NH}$ among patients that had an event during follow-up and those that did not. There was no significant difference between the groups. To get more insight into the predictive value of FXla-C1INH, FXla-AT and FXIla-C1INH, we also determined the odds ratios (OR) for a recurrent event after dichotomizing the data to low levels ( $<$ median of the total group) versus high levels ( $\geq$ median of the total group) of FXla-C1INH and FXla-AT and low levels (below detection limit) and high levels (above detection limit) for FXIla-C1INH. The OR for high compared to low levels of these enzyme inhibitory complexes were: 0.49 (95\% Cl: $0.15-1.6), 1.85$ (95\% Cl: $0.57-6.04)$ and 0.99 (95\% Cl: $0.30-3.25)$ for FXla-C1INH, FXla-AT and FXIla-C1INH, respectively. Only one sample had kallikrein-C1INH levels above the detection limit, therefore no OR was determined. 


\section{Chapter 5}

Table 5.2: Levels of FXIc, FXIlc, D-dimer, F1.2, FXla-C1INH, FXla-AT, FXIla-C1INH and kallikrein-C1INH of acute myocardial infarction patients stratified for the occurrence of a recurrent event during a follow-up period of 1 year

\begin{tabular}{lllll}
\hline & All patients & Recurrent event & No recurrent event & p-value \\
\hline FXIc (U/dl) & $119(17)$ & $117(25)$ & $119(15)$ & 0.68 \\
\hline FXIlc (U/dl) & $101(21)$ & $101(15)$ & $101(22)$ & 0.99 \\
D-dimer (ng/ml) & $370[260-740]$ & $625[382-1325]$ & $360[260-680]$ & 0.04 \\
F1.2 (nmol/ml) & $227[174-319]$ & $314[207-666]$ & $213[170-299]$ & 0.03 \\
FXla-C1INH (A.U.) & $0.22[0.17-0.35]$ & $0.20[0.17-0.30]$ & $0.22[0.17-0.41]$ & 0.47 \\
FXla-AT (A.U.) & $0.26[0.23-0.31]$ & $0.29[0.25-0.35]$ & $0.26[0.23-0.30]$ & 0.17 \\
\hline FXIla-C1INH (A.U.) & $0.03[0.03-0.05]$ & $0.03[0.03-0.06]$ & $0.03[0.03-0.05]$ & 0.92 \\
\hline Kallikrein-C1INH (A.U.) & $0.03[0.03-0.03]$ & $0.03[0.03-0.03]$ & $0.03[0.03-0.03]$ & 0.67 \\
\hline
\end{tabular}

Levels of FXIc and FXIIc are expressed as mean (standard deviation). The other levels are expressed as median [interquartile range]. A.U: arbitrary units, $\mathrm{C} 1 \mathrm{INH}$ : C1-esterase inhibitor

p-value: recurrent compared to no recurrent event
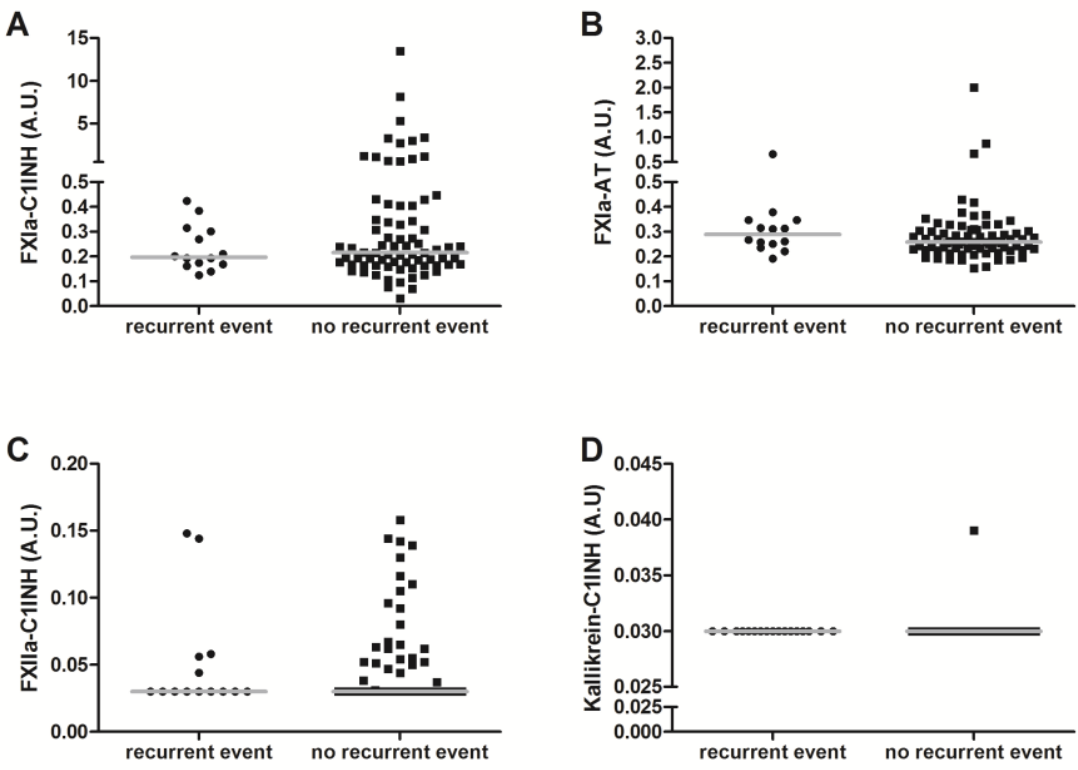

Figure 5.2: Levels of FXla-C1INH (A), FXla-AT (B), FXIla-C1INH (C) and kallikreinC1INH (D) on admission in patients who suffered from a first myocardial infarction. The levels of activated factor XI (FXla), FXIla and kallikrein in complex with C1-esterase inhibitor $(\mathrm{C} 1 \mathrm{INH})$ and $\mathrm{FXla}$ in complex with $\alpha_{1}$-antitrypsin (AT) are subdivided into patients with a recurrent cardiovascular event within the first year after the AMI and those that did not have a recurrent event. The grey line depicts the median value. 


\section{Discussion}

Although experimental studies show an involvement of the contact system of coagulation in arterial thrombosis, atherosclerosis and ischemic stroke, very little is known about the role of the contact activation system in humans. One problem in human studies is inconsistency in data in relation to outcomes, due to heterogeneity in patient populations as well as in assays that were performed. Another issue is that in previous clinical studies in all cases contact activation indices were determined at one point in time, potentially missing patterns of changes in time that may distinguish acute phase responses from constitutive activity levels.

In this study, we investigated the activation of the contact system of coagulation during the acute phase, and 3 and 6 months after the AMI. Furthermore, we explored whether activation of the contact system during the acute phase could be used to predict clinical outcome after a first AMI. Activation of the contact system was measured as the levels of the activated enzymes in complex with their natural inhibitors: FXla, FXIla and kallikrein in complex with $\mathrm{C} 1 \mathrm{INH}$ and FXla in complex with AT. We ensured that samples did not contain any anticoagulant by careful selection at inclusion as well as by screening samples by anti-Xa activity for spurious LMWH presence (data not shown) [21].

We found that the levels of FXla-C1INH were elevated during the acute event in patients with a first AMI compared to the steady state situation 3 and 6 months after the AMI. We did not observe this effect for FXla-AT. Upon activation, $\mathrm{C} 1 \mathrm{NHH}$ is the main inhibitor of FXla, but, the half-life of the FXla-AT complex in vivo is longer than the half-life of $\mathrm{FXla}-\mathrm{C} 1 \mathrm{INH}: 349 \mathrm{~min}$ and $104 \mathrm{~min}$ respectively [22]. Because of this, FXla-AT reflects chronic activation of FXI whereas FXla-C1INH better reflects the acute phase response [22]. This is illustrated in a previous study, where in 20 patients with either an AMI (blood sampling 7 to 10 days after the event) or unstable angina, the levels of FXla-AT were significantly elevated but the levels of FXla-C1INH were comparable to controls [22]. In contrast, Minnema and colleagues showed that patients with an AMI had higher levels of FXla-C1INH during the acute attack compared to patients with stable angina pectoris. In these patients, the levels of FXla-AT were not elevated during the acute attack [2]. In contrast to the present study, they did not obtain follow up blood samples, such that the comparison could only be made between those with $\mathrm{AMI}$ and patients with either unstable or stable angina [2].

The levels of FXIla-C1INH were not elevated during the acute attack, suggesting that in these patients FXI activation was probably caused by an 


\section{Chapter 5}

increase in thrombin generation rather than by FXII activation. Indeed, as reported previously, thrombin generation capacity was increased during AMI. The measurement of the endogenous thrombin potential (ETP) in these patients, showed that the ETP-values were highest during the acute attack and were diminished 3 and 6 months after the event [21].

We observed that higher levels of D-dimer and F1.2 on admission were associated with a recurrent cardiovascular event in the year following the first AMI in this study. This is in agreement with earlier findings. The level of the activation peptide of prothrombin, F1.2, was found to be elevated in patients with ACS and was associated with cardiac mortality and long-term outcome in patients with ACS [23-25]. Elevated levels of D-dimer are observed in patients with ACS [25] and are a predictor for coronary heart disease [26]. Furthermore, elevated levels of D-dimer are predictive of a recurrent coronary event in post infarction patients and in patients with ischemic-type chest pain $[27,28]$. In our study the levels of the inhibitory complexes on admission were not predictive for the occurrence of a recurrent event in the year after the first AMI. High levels of FXla-C1INH, FXIa-AT, FXIla-C1INH and kallikrein-C1INH were not a risk factor for the occurrence of a recurrent cardiovascular event during the follow-up period. Possibly, the study was underpowered to demonstrate the predictive value for the enzyme-inhibitory complexes, however, the OR's were in no way indicative of any risk association. Similarly, in a larger study in patients with chest pain, the levels of FXla-C1INH, FXla-AT, FXIla-C1INH and kallikrein$\mathrm{C} 1 \mathrm{INH}$ were also not predictive for clinical outcomes 2 years after admission. This was the case both for patients with TnT-levels $\leq 0.05 \mathrm{ng} / \mathrm{ml}$ and TnT-levels $>0.05 \mathrm{ng} / \mathrm{ml}$ on admission [20].

We observed a high correlation between the levels of the enzyme inhibitory complexes on admission and those during follow-up. This indicates that in patients with relatively high levels of enzyme inhibitory complexes, these levels stay relatively high. However, they did not predict a recurrent cardiovascular event in the year after a first AMI. This highlights the fact that in spite of a marked interindividual variation in constitutive levels of contact activation, the link between individual levels of these products and arterial vascular disease remains to be explored.

In conclusion, we observed that during an AMI the levels of FXla-C1INH were elevated compared to the steady state 3 and 6 months after the AMI. In the absence of evidence of acute FXII activation, the temporary increase may primarily result from thrombin generation and feedback FXI activation. The main 
contribution of FXII in this regard may be in starting and strengthening (arterial) clot formation [29]. The clinical significance of contact activation in the context of coronary artery disease remains to be demonstrated.

\section{Acknowledgements}

This study was supported by a grant from the Profileringsfonds of the Maastricht University Medical Centre and by an unrestricted grant from Pfizer, the Netherlands. Joke Konings is supported by the Netherlands Heart Foundation (grant 2008B120). The sponsors had no involvement in the analysis of the data or writing of the manuscript. 


\section{References}

1. Merlini PA, Bauer KA, Oltrona L, Ardissino D, Cattaneo M, Belli C, Mannucci PM, Rosenberg RD. Persistent activation of coagulation mechanism in unstable angina and myocardial infarction. Circulation. 1994; 90: 61-8.

2. Minnema MC, Peters RJ, de Winter R, Lubbers YP, Barzegar S, Bauer KA, Rosenberg RD, Hack CE, ten Cate H. Activation of clotting factors XI and IX in patients with acute myocardial infarction. Arterioscler Thromb Vasc Biol. 2000; 20: 2489-93.

3. Orbe J, Zudaire M, Serrano R, Coma-Canella I, Martinez de Sizarrondo S, Rodriguez JA, Paramo JA. Increased thrombin generation after acute versus chronic coronary disease as assessed by the thrombin generation test. Thromb Haemost. 2008; 99: 382-7.

4. Borissoff Jl, Heeneman S, Kilinc E, Kassak P, Van Oerle R, Winckers K, GoversRiemslag JW, Hamulyak K, Hackeng TM, Daemen MJ, ten Cate H, Spronk HM. Early atherosclerosis exhibits an enhanced procoagulant state. Circulation. 2010; 122: 821-30.

5. Doggen CJ, Rosendaal FR, Meijers JC. Levels of intrinsic coagulation factors and the risk of myocardial infarction among men: Opposite and synergistic effects of factors XI and XII. Blood. 2006; 108: 4045-51.

6. Merlo C, Wuillemin WA, Redondo M, Furlan M, Sulzer I, Kremer-Hovinga J, Binder $\mathrm{BR}$, Lammle B. Elevated levels of plasma prekallikrein, high molecular weight kininogen and factor XI in coronary heart disease. Atherosclerosis. 2002; 161: 2617.

7. Berliner JI, Rybicki AC, Kaplan RC, Monrad ES, Freeman R, Billett HH. Elevated levels of Factor XI are associated with cardiovascular disease in women. Thromb Res. 2002; 107: 55-60.

8. Siegerink B, Govers-Riemslag JW, Rosendaal FR, Ten Cate H, Algra A. Intrinsic coagulation activation and the risk of arterial thrombosis in young women: results from the Risk of Arterial Thrombosis in relation to Oral contraceptives (RATIO) case-control study. Circulation. 2010; 122: 1854-61.

9. Tanis B, Algra A, van der Graaf Y, Helmerhorst F, Rosendaal F. Procoagulant factors and the risk of myocardial infarction in young women. Eur $J$ Haematol. 2006; 77: 67-73.

10. Salomon O, Steinberg DM, Dardik R, Rosenberg N, Zivelin A, Tamarin I, Ravid B, Berliner S, Seligsohn U. Inherited factor XI deficiency confers no protection against acute myocardial infarction. J Thromb Haemost. 2003; 1: 658-61.

11. Endler G, Marsik C, Jilma B, Schickbauer T, Quehenberger P, Mannhalter C. Evidence of a U-shaped association between factor XII activity and overall survival. J Thromb Haemost. 2007; 5: 1143-8.

12. Bach J, Endler G, Winkelmann BR, Boehm BO, Maerz W, Mannhalter C, Hellstern P. Coagulation factor XII (FXII) activity, activated FXII, distribution of FXII C46T gene polymorphism and coronary risk. J Thromb Haemost. 2008; 6: 291-6.

13. Cooper JA, Miller GJ, Bauer KA, Morrissey JH, Meade TW, Howarth DJ, Barzegar $\mathrm{S}$, Mitchell JP, Rosenberg RD. Comparison of novel hemostatic factors and conventional risk factors for prediction of coronary heart disease. Circulation. 2000; 102: 2816-22.

14. Altieri P, Devoto E, Spallarossa P, Rossettin P, Garibaldi S, Bertero G, Balbi M, Barsotti A, Brunelli C, Ghigliotti G. Acute coronary syndromes do not promote prolonged in vivo FXII-dependent prothrombotic activity. Thromb Res. 2005; 115: 65-72. 
15. Kohler HP, Carter AM, Stickland MH, Grant PJ. Levels of activated FXII in survivors of myocardial infarction--association with circulating risk factors and extent of coronary artery disease. Thromb Haemost. 1998; 79: 14-8.

16. Miller GJ, Esnouf MP, Burgess Al, Cooper JA, Mitchell JP. Risk of coronary heart disease and activation of factor XII in middle-aged men. Arterioscler Thromb Vasc Biol. 1997; 17: 2103-6.

17. Grundt H, Nilsen DW, Hetland O, Valente E, Fagertun HE. Activated factor 12 (FXIla) predicts recurrent coronary events after an acute myocardial infarction. Am Heart J. 2004; 147: 260-6.

18. Govers-Riemslag JW, Smid M, Cooper JA, Bauer KA, Rosenberg RD, Hack CE, Hamulyak K, Spronk HM, Miller GJ, ten Cate H. The plasma kallikrein-kinin system and risk of cardiovascular disease in men. J Thromb Haemost. 2007; 5: 1896-903.

19. Lowe GD, Rumley A, McMahon AD, Ford I, O'Reilly DS, Packard CJ. Interleukin-6, fibrin D-dimer, and coagulation factors VII and XIla in prediction of coronary heart disease. Arterioscler Thromb Vasc Biol. 2004; 24: 1529-34.

20. Ponitz V, Govers-Riemslag JW, Brugger-Andersen T, ten Cate H, Nilsen DW. Inhibitor complexes of the plasma kallikrein-kinin system and outcome prediction in patients following admission for chest pain. J Thromb Haemost. 2009; 7: 1231-3.

21. Smid M, Dielis AW, Winkens M, Spronk HM, van Oerle R, Hamulyak K, Prins MH, Rosing $\mathrm{J}$, Waltenberger $\mathrm{JL}$, ten Cate $\mathrm{H}$. Thrombin generation in patients with a first acute myocardial infarction. J Thromb Haemost. 2011; 9: 450-6.

22. Wuillemin WA, Hack CE, Bleeker WK, Biemond BJ, Levi M, ten Cate H. Inactivation of factor Xia in vivo: studies in chimpanzees and in humans. Thromb Haemost. 1996; 76: 549-55.

23. Ardissino D, Merlini PA, Bauer KA, Galvani M, Ottani F, Franchi F, Bertocchi F, Rosenberg RD, Mannucci PM. Coagulation activation and long-term outcome in acute coronary syndromes. Blood. 2003; 102: 2731-5.

24. Li YH, Teng JK, Tsai WC, Tsai LM, Lin LJ, Guo HR, Chen JH. Prognostic significance of elevated hemostatic markers in patients with acute myocardial infarction. J Am Coll Cardiol. 1999; 33: 1543-8.

25. van der Putten RF, Glatz JF, Hermens WT. Plasma markers of activated hemostasis in the early diagnosis of acute coronary syndromes. Clin Chim Acta. 2006; 371: 37-54.

26. Danesh J, Whincup P, Walker M, Lennon L, Thomson A, Appleby P, Rumley A, Lowe GD. Fibrin D-dimer and coronary heart disease: prospective study and metaanalysis. Circulation. 2001; 103: 2323-7.

27. Moss AJ, Goldstein RE, Marder VJ, Sparks CE, Oakes D, Greenberg H, Weiss HJ, Zareba W, Brown MW, Liang CS, Lichstein E, Little WC, Gillespie JA, Van Voorhees L, Krone RJ, Bodenheimer MM, Hochman J, Dwyer EM, Jr., Arora R, Marcus FI, et al. Thrombogenic factors and recurrent coronary events. Circulation. 1999; 99: 2517-22.

28. Menown IB, Mathew TP, Gracey HM, Nesbitt GS, Murray P, Young IS, Adgey AA. Prediction of Recurrent Events by D-Dimer and Inflammatory Markers in Patients with Normal Cardiac Troponin I (PREDICT) Study. Am Heart J. 2003; 145: 986-92.

29. Konings J, Govers-Riemslag JW, Philippou H, Mutch NJ, Borissoff JI, Allan P, Mohan S, Tans G, Ten Cate H, Ariens RA. Factor Xlla regulates the structure of the fibrin clot independently of thrombin generation through direct interaction with fibrin. Blood. 2011; 118: 3942-51. 



\section{Chapter 6}

\section{Fibrin clot formation and fibrinolysis in patients with}

coronary stent thrombosis

J. Konings *, T.C. Godschalk *, J.W.P. Govers-Riemslag, J.M. ten Berg, C.M. Hackeng, H. ten Cate

* These authors contributed equally to this research 


\section{Chapter 6}

\section{Abstract}

Background: Coronary stent thrombosis (ST) is a feared complication of percutaneous coronary intervention (PCl). Multiple factors underlie the pathophysiological mechanisms of ST. Previous studies demonstrated that patients with ST, compared to control PCI patients, formed denser fibrin clots which were more resistant to fibrinolysis. This suggests that alterations in fibrin clot formation and lysis could contribute to the pathophysiology of ST.

Objective: To assess the plasma fibrin clot formation and fibrinolysis of ST patients compared to control $\mathrm{PCl}$ patients.

Patients/Methods: A total of 54 patients were included: 27 cases (patients with definite ST) and 27 matched controls (PCI patients without ST). Controls were matched based on indication and time of the index $\mathrm{PCl}(\mathrm{PCl}$ of initial stent implantation) of cases. Fibrin clot formation and fibrinolysis were assessed by turbidimetric assays. The lag time, maximal absorbance and clot lysis time were derived from these assays.

Results: No significant difference was found between cases and matched controls in lag time (173.4 $s \pm 46.6$ vs. $161.5 \mathrm{~s} \pm 27.5, \mathrm{p}=0.18$ ), maximal absorbance $(0.78 \pm 0.16$ vs. $0.83 \pm 0.21, p=0.36)$, and clot lysis time (69.2 $\mathrm{min} \pm 20.0$ vs. $71.3 \mathrm{~min} \pm 25.3, p=0.78$ ).

Conclusions: Fibrin clot formation and fibrinolysis were not different between patients with ST and matched control patients. The inclusion of more patients with late ST in our study might be the main reason for the discrepancy with earlier observations. Further research to fibrin clot properties in patients with ST is needed to elucidate these inconsistent results. 


\section{Introduction}

Coronary stent thrombosis (ST) is a feared complication of percutaneous coronary intervention $(\mathrm{PCl})$ associated with a considerable morbidity and mortality [1-3]. The incidence of ST is approximately $1-4 \%$, despite dual antiplatelet therapy (DAPT) with aspirin and clopidogrel [2-5]. Multiple factors underlie the pathophysiological mechanisms of ST, such as stent under expansion and high residual platelet reactivity (HPR) $[5,6]$.

Thrombus formation includes the interplay of platelet activation and aggregation with the formation of a fibrin clot, both mediated by thrombin. Fibrinolysis of the fibrin clot is initiated by the conversion of plasminogen into plasmin. The stability of the fibrin clot is largely determined by fibrin clot formation and susceptibility to fibrinolysis. Clot stability is influenced by environmental and genetic factors, including the concentration and function of fibrinogen and the amount of thrombin formed [7].

Previous studies have shown that patients with cardiovascular disease (CVD) exhibited abnormal fibrin clot formation, characterized by dense structures with increased stiffness, decreased permeability, and decreased clot lysis [8,9]. A single study by Undas et al. [10,11] demonstrated that patients with ST, compared to control PCl patients, formed denser fibrin clots which were more resistant to fibrinolysis.

Because HPR status [6] and hypercoagulability [unpublished results Godschalk et al] are characteristics of stent thrombosis patients, we hypothesize that fibrin clot formation and fibrinolysis could also be altered in patients with ST which could contribute to the pathophysiology of ST. Therefore, we assessed the plasma fibrin clot formation and fibrinolysis of patients with ST compared to control PCl patients.

\section{Materials and methods}

Study design and population

A single-center case-control study including $\mathrm{PCl}$ patients with stent implantation was performed. Cases underwent an index $\mathrm{PCl}$ ( $\mathrm{PCl}$ of initial stent implantation) after which they suffered from an angiographically confirmed ST (according to the Academic Research Consortium criteria) [12]. Controls underwent an index $\mathrm{PCl}$ without suffering from $\mathrm{ST}$ between index $\mathrm{PCl}$ and blood sampling. Control patients were matched based on the indication and time ( \pm 14 days) of the index $\mathrm{PCl}$ of cases. Subjects using oral anticoagulants or heparins at the time of blood collection were excluded. 


\section{Chapter 6}

Written informed consent was provided by all participants. The study was approved by the local institutional Ethics Committee and was conducted according to the principles of the Declaration of Helsinki.

\section{Blood collection and preparation}

All subjects were invited for blood sampling to the St. Antonius Hospital (Nieuwegein, The Netherlands). The minimal time interval, for cases, between $\mathrm{PCl}$ performed at time of ST and blood sampling was one month. For controls, the minimal time interval between index $\mathrm{PCl}$ and blood sampling was one month. Venous blood samples were collected from the antecubital vein using 21-gauge needles and Vacuette ${ }^{\circledR}$ tubes (Greiner Bio-one, Frickenhausen, Germany) containing $3.2 \%(\mathrm{w} / \mathrm{v})$ sodium citrate. To avoid hemostatic activation, the first $5 \mathrm{ml}$ of free-flowing blood was discarded. Platelet poor plasma (PPP) was obtained by two separate centrifugation steps. Samples were first centrifuged for $10 \mathrm{~min}$ at $150 \mathrm{~g}$, followed by $15 \mathrm{~min}$ at $2.500 \mathrm{~g}$. All PPP samples were stored at $-80^{\circ} \mathrm{C}$ until analysis.

\section{Fibrin clot formation and fibrinolysis assay}

Plasma samples were diluted 1.67 times with Hepes-buffer $(25 \mathrm{mM}$ Hepes, $150 \mathrm{mM} \mathrm{NaCl}, \mathrm{pH}=7.5$ ) and $125 \mu \mathrm{l}$ of diluted plasma was transferred into a low binding polystyrene 96-well plate (Greiner, Frickenhauser, Germany). Fibrin polymerization was started by addition of $25 \mu$ of activation mix containing thrombin (Enzyme Research Laboratories, Swansea, UK) (final concentration: $0.75 \mathrm{nM}$ ), phospholipids (1,2-dioleoyl-sn-glycero-3-phosphoserine, 1,2-dioeoylsn-glycero-3-phosphocholine, 1,2-dioleoyl-snglycero-3-phosphoethanolamine (DOPS/DOPC/DOPE, 20/60/20, $\mathrm{mol} / \mathrm{mol} / \mathrm{mol}$ ) were from Avanti Polar lipids Inc (Alabaster, AL) and were prepared by sonication as described earlier [13]) (final concentration: $10 \mu \mathrm{M}$ ) and $\mathrm{CaCl}_{2}$ (final concentration: $16 \mathrm{mM}$ ) and was measured at $405 \mathrm{~nm}$ every $15 \mathrm{~s}$ for $60 \mathrm{~min}$ at $37^{\circ} \mathrm{C}$ using a ELx808 plate reader (Biotek Instruments, Winooski, VT). The lag time, defined as the time to an increase of 0.01 in turbidity from baseline, together with the maximal absorbance were determined from the curves of the turbidity measurements.

To monitor fibrinolysis, recombinant tissue plasminogen activator (tPA) (Boehringer Ingelheim, Alkmaar, the Netherlands) (final concentration: $50 \mathrm{ng} / \mathrm{ml}$ ) was added to the activation mix and turbidity was recorded for 6 hours. Clot lysis time was calculated as the time from $50 \%$ clot formation to $50 \%$ fibrinolysis. Turbidity measurements were performed in duplicate and lysis measurements in triplicate. 


\section{Laboratory measurements}

Plasma concentrations of fibrinogen were measured using a Sysmex ${ }^{\circledR}$ CA-7000 System Automated Coagulation Analyzer with reagents obtained from Siemens Healthcare Diagnostics (Marburg, Germany) according to the Claus method [14]. Platelet count was measured using a LH 750 (Beckman Coulter) and cholesterol levels were measured using a Cobas 6000 (Roche Diagnostics). Hypercholesterolemia was defined as an increased level of total cholesterol ( $>5.0 \mathrm{mmol} / \mathrm{l})$, triglycerides $(>1.5 \mathrm{mmol} / \mathrm{l})$, or LDL $(>2.5 \mathrm{mmol} / \mathrm{l})$ or a decreased level of $\mathrm{HDL}(<1.5 \mathrm{mmol} / \mathrm{l})$ or statin use.

\section{Statistical analysis}

Statistical analyses were performed with PRISM for Windows, version 5.00 (GraphPad Software, San Diego, CA, USA), and SPSS version 21.0 (SPSS inc., Chicago, IL, USA). According to the distribution of variables (D'Agostino \& Pearson omnibus normality test), data are expressed as mean \pm standard deviation (SD), and categorical data are expressed as frequencies no./total no.(\%).

Baseline characteristics, differences between cases and controls in lag time, maximal absorbance, clot lysis time, and fibrinogen levels were analyzed using a paired Student's t-test or $x^{2}$ as appropriate. A two-tailed $p$-value $<0.05$ was considered as statistically significant.

\section{Results}

\section{$\underline{\text { Patients }}$}

A total of 27 cases and 27 matched control patients were included. From the cases, 12 patients had experienced an early ST ( $\leq 30$ days after $\mathrm{PCl})$ and 15 patients a late ST ( $>30$ days after $\mathrm{PCl}$ ). None of the matched controls experienced a ST between index $\mathrm{PCl}$ and blood sampling. Baseline characteristics are summarized in Table 6.1. Compared to controls, significantly more cases were current smokers (cases vs. controls: $72.0 \%$ vs. $33.3 \%$, $p=0.005$ ) and suffered from hypertension (cases vs. controls: $48.1 \%$ vs. $18.5 \%, p=0.021$ ) at time of index $\mathrm{PCl}$.

The mean time-interval between ST and blood sampling for cases was $35.3 \pm 25.2$ months and between index $\mathrm{PCl}$ and blood sampling for controls was $41.8 \pm 26.2$ months. More cases $(74.1 \%)$ than controls $(37.0 \%)$ were on DAPT $(p=0.006)$ at the time of blood sampling, as DAPT was continued beyond 1 year after $\mathrm{PCl}$ in patients with $\mathrm{ST}$ and not in controls. Two cases were still 


\section{Chapter 6}

within 1 year after ST during blood sampling. Statin use was similar in both groups.

Table 6.1 Baseline characteristics at time of index PCI

\begin{tabular}{|c|c|c|c|}
\hline & Cases $(n=27)$ & Matched controls $(n=27)$ & $p$ \\
\hline & no./total no. (\%) & no./total no. (\%) & \\
\hline \multicolumn{4}{|l|}{ Clinical characteristics } \\
\hline Female & $4 / 27(14.8)$ & $3 / 27(11.1)$ & 0.69 \\
\hline Age, (years) & $57.0 \pm 11.0$ & $59.8 \pm 9.4$ & 0.24 \\
\hline Body mass index, $\left(\mathrm{kg} / \mathrm{m}^{2}\right)$ & $26.4 \pm 3.1$ & $26.9 \pm 3.4$ & 0.49 \\
\hline Current smoking & $18 / 25(72.0)$ & 9/27 (33.3) & 0.005 \\
\hline Hypertension & $13 / 27(48.1)$ & $5 / 27(18.5)$ & 0.021 \\
\hline Diabetes mellitus & $5 / 27(18.5)$ & $3 / 27(11.1)$ & 0.44 \\
\hline Hypercholesterolemia & $16 / 27(59.3)$ & $12 / 25(48.0)$ & 0.43 \\
\hline Family history of CVD & 19/26 (73.1) & $15 / 27(55.6)$ & 0.18 \\
\hline \multicolumn{4}{|l|}{ Medical history } \\
\hline Prior Ml & 9/27 (33.3) & $5 / 27(18.5)$ & 0.21 \\
\hline Prior $\mathrm{PCl}$ & $7 / 27(25.9)$ & $8 / 27(29.6)$ & 0.76 \\
\hline Prior CABG & $1 / 27(3.7)$ & $1 / 27(3.7)$ & 1.00 \\
\hline Malignancy & $1 / 27(3.7)$ & $3 / 27(11.1)$ & 0.30 \\
\hline \multicolumn{4}{|l|}{ Indication } \\
\hline Stable angina pectoris & 9/27 (33.3) & 9/27 (33.3) & \multirow{3}{*}{$\begin{array}{l}\text { Matched } \\
\text { item }\end{array}$} \\
\hline UAP / NSTEMI & $4 / 27(14.8)$ & $4 / 27(14.8)$ & \\
\hline STEMI & $14 / 27(51.9)$ & $14 / 27(51.9)$ & \\
\hline \multicolumn{4}{|l|}{ Procedural Characteristics } \\
\hline Bare metal stents & 9/27 (33.3) & $11 / 27(40.7)$ & \multirow{2}{*}{0.57} \\
\hline Drug eluting stents & $18 / 27(66.7)$ & 16/27 (59.3) & \\
\hline Total stent length, (mm) & $27.0 \pm 13.6$ & $23.3 \pm 10.5$ & 0.27 \\
\hline \multicolumn{4}{|l|}{ Antiplatelet therapy } \\
\hline GP IIb/IIla therapy & $8 / 27(29.6)$ & 6/27 (22.2) & 0.54 \\
\hline Aspirin & $24 / 25(96.0)$ & $26 / 27(96.3)$ & 0.96 \\
\hline Clopidogrel & $23 / 25(92.0)$ & 24/27 (88.9) & 0.70 \\
\hline Coumadin & $0 / 27$ & $0 / 27$ & NA \\
\hline
\end{tabular}

CABG, coronary artery bypass graft; CVD, cardiovascular disease; GP, glycoprotein; MI, myocardial infarction; NA, not applicable; NSTEMI, non-ST-segment elevated myocardial infarction; $\mathrm{PCl}$, percutaneous coronary intervention; STEMI, ST-segment elevated myocardial infarction; UAP, unstable angina pectoris. Continuous data are presented as mean \pm SD. 


\section{Fibrin clot properties}

Cases and matched controls were not significantly different in clot formation for lag time (173.4 $\mathrm{s} \pm 46.6$ vs. $161.5 \mathrm{~s} \pm 27.5, \mathrm{p}=0.18)$ and maximal absorbance $(0.78 \pm 0.16$ vs. $0.83 \pm 0.21, p=0.36)$. Furthermore, clot lysis time was not significantly different between cases and controls $(69.2 \mathrm{~min} \pm 20.0$ vs. $71.3 \mathrm{~min} \pm 25.3, p=0.78$ ), see Figure 6.1. Subgroup analyses were performed to compare early vs. late ST in cases, and to compare patients with early ST with their matched controls and patients with late ST and their matched controls. These subgroup analyses did not show significant differences in lag time, maximal absorbance and clot lysis time (data not shown). Fibrinogen levels were correlated with maximal absorbance for cases and controls $(r=0.91$ and $r=0.91$, both $p<0.001$ ). Fibrinogen levels, cholesterol levels and platelet count were not significantly different between cases and matched controls (see Table 6.2).
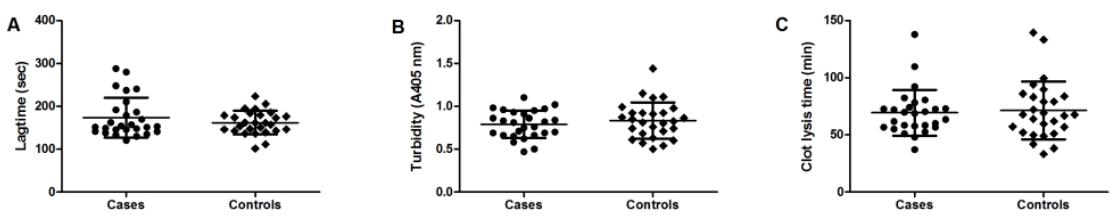

Figure 6.1: The lag time, maximal turbidity and clot lysis time in stent thrombosis patients and matched controls.

Clots were formed from platelet poor plasma (PPP) of patient with stent thrombosis and matched controls, by activating coagulation with thrombin $(0.75 \mathrm{nM})$, phospholipids $(10 \mu \mathrm{M})$ and $\mathrm{CaCl} 2(16 \mathrm{mM})$ and to determined fibrinolysis, tPA $(50 \mathrm{ng} / \mathrm{ml})$ was added to this mixture. Changes in turbidity were measured at $405 \mathrm{~nm}$ every $15 \mathrm{~s}$ at $37^{\circ} \mathrm{C}$. From these curves, (A) lag time, (B) maximal absorbance and (C) clot lysis time were determined. Data are expressed as mean \pm SD. 
Table 6.2 Characteristics at time of blood sampling

\begin{tabular}{llll}
\hline & Cases $(\mathbf{n}=\mathbf{2 7})$ & Matched controls $(\mathbf{n}=\mathbf{2 7})$ & $\mathbf{p}$ \\
\hline Medication & & & \\
\hline Aspirin & $27 / 27(100.0)$ & $27 / 27(100.0)$ & 1.00 \\
\hline DAPT & $20 / 27(74.1)$ & $10 / 27(37.0)$ & 0.006 \\
\hline Clopidogrel & $13 / 27(48.1)$ & $8 / 27(29.6)$ & 0.16 \\
Prasugrel & $5 / 27(18.5)$ & $2 / 27(7.4)$ & 0.22 \\
\hline Ticagrelor & $2 / 27(7.4)$ & $0 / 27(0.0)$ & 0.15 \\
Statins & $27 / 27(100)$ & $25 / 27(92.6)$ & 0.15 \\
Laboratory measurements & & & 0.88 \\
\hline Fibrinogen, $(\mathrm{g} / \mathrm{l})$ & $3.5 \pm 0.7$ & $3.6 \pm 0.7$ & 0.34 \\
\hline Platelet count, $\left(10^{3} / \mu \mathrm{l}\right)$ & $225 \pm 42$ & $211 \pm 50$ & 0.97 \\
Total cholesterol, $(\mathrm{mmol} / \mathrm{l})$ & $4.1 \pm 0.8$ & $4.1 \pm 0.9$ & 0.12 \\
\hline LDL cholesterol, $(\mathrm{mmol} / \mathrm{l})$ & $2.1 \pm 0.7$ & $1.9 \pm 0.6$ & 0.71 \\
\hline HDL cholesterol, $(\mathrm{mmol} / \mathrm{l})$ & $1.25 \pm 0.80$ & $1.19 \pm 0.32$ & 0.34 \\
\hline Triglycerides, $(\mathrm{mmol} / \mathrm{l})$ & $1.8 \pm 0.8$ & $2.0 \pm 1.3$ & \\
\hline DAPT, dual antiplatelet & & & \\
\hline
\end{tabular}

DAPT, dual antiplatelet therapy; HDL, high density lipoprotein; LDL, low density lipoprotein; $\mathrm{PCl}$, percutaneous coronary intervention. Continuous data are presented as mean \pm SD and categorical data as no./total no. (\%).

\section{Discussion}

This study showed that fibrin clot formation and fibrinolysis were comparable between patients with ST and matched controls. Also, fibrinogen levels and platelet count were equal between cases and controls.

Our results are contrary to earlier observations. Undas et al. [10] showed that plasma clots from patients with ST had changed fibrin clot properties: they observed lower permeation, reduced compaction, a shorter lag phase, less fibrinolysis, and a higher maximal absorbance. Subsequent investigation within this patient group showed that patients with early ST had an impaired fibrinolytic potential [11]. Our study differs from these previous studies at four points. First, the methods used for the fibrin clot formation and lysis assays were slightly different. The clot lysis assay is a widely used assay, however, the test conditions differ between laboratories [15]. Compared to the previous studies in ST, the concentration of thrombin and IPA used in the assays were lower in our study compared to the first study by Undas et al. In the latter study, tissue factor instead of thrombin was used to initiate coagulation. Second, the baseline characteristics of the study populations differ between the studies. The control patients from the previous studies were matched for cardiovascular risk [10], 
whereas we matched cases and controls based on indication and time of the index $\mathrm{PCl}$. In our study group, more cases were smokers and suffered from hypertension at time of index $\mathrm{PCl}$ compared to controls. Smoking and hypertension both have an effect on fibrin clot properties. Smoking increased the clot strength and the resistance to fibrinolysis [16,17]. The use of antihypertensive agents increased the permeability and reduced the resistance to fibrinolysis in patients with arterial hypertension [18]. Nevertheless, no differences were observed for the different parameters between patients with ST and controls. Third, the proportion of included patients with early ST was different. Due to consecutive inclusion of patients with ST, a comparable number of patients with early ST and patients with late ST was included in our population, while in the studies of Undas et al. predominantly patients with early ST were included $[10,11]$. The risk factors for early ST and late ST seem to differ, as is apparent from the fact that high platelet reactivity despite administration of aspirin and clopidogrel is especially an important risk factor for patients with early ST and less for patients with late ST [6]. Hypothetically, the role of a disturbed primary hemostasis in the pathophysiology of early ST might go along with a disturbance in fibrin clot formation and fibrinolysis. Our subgroup analysis did not show an effect on fibrin clot formation and fibrinolysis on the occurrence of early ST, however, only 12 patients experienced an early ST in our study. Determination of fibrin clot formation and fibrinolysis in more patients with early and late ST is needed to determine if these fibrin properties differ between patients. Last, in $90 \%$ of the patients a bare metal stent (BMS) was implanted in the previous studies, while in our population a BMS was placed in approximately $35 \%$ of the patients. The use of drug eluting stents (DES) in daily clinical practice is increased because DES has significantly reduced in-stent restenosis compared to BMS. However, DES implantation is associated with an increased risk of late ST [19], due to delayed vascular healing, which is characterized by fibrin deposition [20], poor reendothelialization [21], and late stent malapposition [22]. In our study population, $56 \%$ of patients suffered from late ST, compared to $13 \%$ in the study by Undas et al [10]. Presumably, altered fibrin clot properties are related to the type of ST, and especially related to early ST.

Fibrin clot formation and lysis are influenced by genetic and environmental factors, including fibrinogen levels, smoking, hypercholesterolemia, and aspirin and statin use $[7,23]$. These factors were all comparable between cases and controls. However, DAPT was significantly more prescribed to cases. Studies showed contrary results in clopidogrel altering fibrinogen levels [24,25] and whether P2Y12 inhibitors alter fibrin clot properties is unknown. Therefore, we 


\section{Chapter 6}

cannot rule out that the difference in DAPT use between cases and controls has diminished the expected differences in fibrin clot properties.

We acknowledge several limitations of the present study. First, the number of patients included was small. Therefore, extrapolation to the cohort of all PCl patients is difficult, however, patients with early and late ST were equally represented. Due to the small number of patients, the reliability of the sub group analysis is questionable. Second, the amount of PPP was limited and restricted the possibilities for laboratory measurements of individual fibrinolytic components. Third, the interplay between fibrin and platelets or other blood cell components is not incorporated in the turbidity and lysis measurements as these were performed in PPP. Four, we did not take into consideration the cause of ST, which can be variable and is often unknown. Last, results of the turbidity and lysis measurements could not be correlated to available platelet function results from the included patients since these platelet function data are influenced by DAPT use, which is significantly different in the two groups.

In conclusion, fibrin clot formation and fibrinolysis were not different between patients with ST and matched control patients. A clear reason for the discrepancy with earlier observations could not be pinpointed. However, more patients with late ST were included in our study population, which can be an explanation for these different results. Further research to fibrin clot properties in patients with ST is needed to elucidate these inconsistent results.

\section{Acknowledgements}

This work was supported by the Netherlands Heart Foundation (grant 2008B120). 


\section{References}

1. van Werkum JW, Heestermans AA, de Korte FI, Kelder JC, Suttorp MJ, Rensing BJ, Zwart B, Brueren BR, Koolen JJ, Dambrink JH, van't Hof AW, Verheugt FW, ten Berg JM. Long-term clinical outcome after a first angiographically confirmed coronary stent thrombosis: an analysis of 431 cases. Circulation. 2009 ; 119: 82834.

2. de la Torre-Hernandez JM, Alfonso F, Hernandez F, Elizaga J, Sanmartin M, Pinar E, Lozano I, Vazquez JM, Botas J, Perez de Prado A, Hernandez JM, Sanchis J, Nodar JM, Gomez-Jaume A, Larman M, Diarte JA, Rodriguez-Collado J, Rumoroso JR, Lopez-Minguez JR, Mauri J. Drug-eluting stent thrombosis: results from the multicenter Spanish registry ESTROFA (Estudio ESpanol sobre TROmbosis de stents FArmacoactivos). Journal of the American College of Cardiology. 2008; 51: 986-90.

3. lakovou I, Schmidt T, Bonizzoni E, Ge L, Sangiorgi GM, Stankovic G, Airoldi F, Chieffo A, Montorfano M, Carlino M, Michev I, Corvaja N, Briguori C, Gerckens U, Grube E, Colombo A. Incidence, predictors, and outcome of thrombosis after successful implantation of drug-eluting stents. JAMA. 2005; 293: 2126-30.

4. Dangas GD, Caixeta A, Mehran R, Parise H, Lansky AJ, Cristea E, Brodie BR, Witzenbichler B, Guagliumi G, Peruga JZ, Dudek D, Moeckel M, Stone GW. Frequency and predictors of stent thrombosis after percutaneous coronary intervention in acute myocardial infarction. Circulation. 2011; 123: 1745-56.

5. van Werkum JW, Heestermans AA, Zomer AC, Kelder JC, Suttorp MJ, Rensing BJ, Koolen JJ, Brueren BR, Dambrink JH, Hautvast RW, Verheugt FW, ten Berg JM. Predictors of coronary stent thrombosis: the Dutch Stent Thrombosis Registry. Journal of the American College of Cardiology. 2009; 53: 1399-409.

6. Bouman HJ, van Werkum JW, Breet NJ, ten Cate H, Hackeng CM, ten Berg JM. A case-control study on platelet reactivity in patients with coronary stent thrombosis. $J$ Thromb Haemost. 2011; 9: 909-16.

7. Scott EM, Ariens RA, Grant PJ. Genetic and environmental determinants of fibrin structure and function: relevance to clinical disease. Arterioscler Thromb Vasc Biol. 2004; 24: 1558-66.

8. Collet JP, Allali Y, Lesty C, Tanguy ML, Silvain J, Ankri A, Blanchet B, Dumaine R, Gianetti J, Payot L, Weisel JW, Montalescot G. Altered fibrin architecture is associated with hypofibrinolysis and premature coronary atherothrombosis. Arterioscler Thromb Vasc Biol. 2006; 26: 2567-73.

9. Fatah K, Silveira A, Tornvall P, Karpe F, Blomback M, Hamsten A. Proneness to formation of tight and rigid fibrin gel structures in men with myocardial infarction at a young age. Thromb Haemost. 1996; 76: 535-40.

10. Undas A, Zalewski J, Krochin M, Siudak Z, Sadowski M, Pregowski J, Dudek D, Janion M, Witkowski A, Zmudka K. Altered plasma fibrin clot properties are associated with in-stent thrombosis. Arterioscler Thromb Vasc Biol. 2010; 30: 27682.

11. Pankiw-Bembenek O, Zalewski J, Goralczyk T, Undas A. A history of early stent thrombosis is associated with prolonged clot lysis time. Thromb Haemost. 2012; 107: 513-20.

12. Cutlip DE, Windecker S, Mehran R, Boam A, Cohen DJ, van Es GA, Steg PG, Morel MA, Mauri L, Vranckx P, McFadden E, Lansky A, Hamon M, Krucoff MW, Serruys PW. Clinical end points in coronary stent trials: a case for standardized definitions. Circulation. 2007; 115: 2344-51.

13. Govers-Riemslag JW, Janssen MP, Zwaal RF, Rosing J. Effect of membrane fluidity and fatty acid composition on the prothrombin-converting activity of phospholipid vesicles. Biochemistry. 1992; 31: 10000-8. 
14. Clauss A. [Rapid physiological coagulation method in determination of fibrinogen]. Acta haematologica. 1957; 17: 237-46.

15. Talens S, Malfliet JJ, Rudez G, Spronk HM, Janssen NA, Meijer P, Kluft C, de Maat MP, Rijken DC. Biological variation in tPA-induced plasma clot lysis time. Thromb Haemost. 2012; 108: 640-6.

16. Barua RS, Sy F, Srikanth S, Huang G, Javed U, Buhari C, Margosan D, Aftab W, Ambrose JA. Acute cigarette smoke exposure reduces clot lysis--association between altered fibrin architecture and the response to t-PA. Thromb Res. 2010; 126: 426-30.

17. Barua RS, Sy F, Srikanth S, Huang G, Javed U, Buhari C, Margosan D, Ambrose JA. Effects of cigarette smoke exposure on clot dynamics and fibrin structure: an ex vivo investigation. Arterioscler Thromb Vasc Biol. 2010; 30: 75-9.

18. Rajzer M, Wojciechowska W, Kawecka-Jaszcz K, Undas A. Plasma fibrin clot properties in arterial hypertension and their modification by antihypertensive medication. Thromb Res. 2012; 130: 99-103.

19. Moses JW, Leon MB, Popma JJ, Fitzgerald PJ, Holmes DR, O'Shaughnessy C, Caputo RP, Kereiakes DJ, Williams DO, Teirstein PS, Jaeger JL, Kuntz RE. Sirolimus-eluting stents versus standard stents in patients with stenosis in a native coronary artery. N Engl J Med. 2003; 349: 1315-23.

20. Joner M, Finn AV, Farb A, Mont EK, Kolodgie FD, Ladich E, Kutys R, Skorija K, Gold HK, Virmani R. Pathology of drug-eluting stents in humans: delayed healing and late thrombotic risk. Journal of the American College of Cardiology. 2006; 48: 193-202.

21. Finn AV, Joner M, Nakazawa G, Kolodgie F, Newell J, John MC, Gold HK, Virmani R. Pathological correlates of late drug-eluting stent thrombosis: strut coverage as a marker of endothelialization. Circulation. 2007; 115: 2435-41.

22. Hassan AK, Bergheanu SC, Stijnen T, van der Hoeven BL, Snoep JD, Plevier JW, Schalij MJ, Wouter Jukema J. Late stent malapposition risk is higher after drugeluting stent compared with bare-metal stent implantation and associates with late stent thrombosis. Eur Heart J. 2010; 31: 1172-80.

23. Undas A, Ariens RA. Fibrin clot structure and function: a role in the pathophysiology of arterial and venous thromboembolic diseases. Arterioscler Thromb Vasc Biol. 2011; 31: e88-99.

24. Izaguirre-Avila $R$, De la Pena-Diaz A, Barinagarrementeria-Aldatz F, GonzalezPacheco H, Ramirez-Gutierrez AE, Ruiz-Sandoval JL, Quiroz-Martinez A, CantuBrito C. Effect of clopidogrel on platelet aggregation and plasma concentration of fibrinogen in subjects with cerebral or coronary atherosclerotic disease. Clin Appl Thromb Hemost. 2002; 8: 169-77.

25. Koltai K, Feher G, Kenyeres P, Lenart I, Alexy T, Horvath B, Marton Z, Kesmarky $\mathrm{G}$, Toth K. Relation of platelet aggregation and fibrinogen levels to advancing age in aspirin- and thienopyridine-treated patients. Clinical hemorheology and microcirculation. 2008; 40: 295-302. 


\section{Chapter 7}

\section{Ongoing contact activation in patients with hereditary angioedema}

J. Konings, M. Cugno, C. Suffritti, H. ten Cate, M. Cicardi, J.W.P. GoversRiemslag

This research was originally published in PLOS ONE. 2013; 8:e74043. 


\section{Chapter 7}

\section{Abstract}

Hereditary angioedema (HAE) is predominantly caused by a deficiency in C1esterase inhibitor (C1INH) (HAE-C1INH). C1INH inhibits activated factor XII (FXIla), activated factor XI (FXla), and kallikrein. In HAE-C1INH patients the thrombotic risk is not increased even though activation of the contact system is poorly regulated. Therefore, we hypothesized that contact activation preferentially leads to kallikrein formation and less to activation of the coagulation cascade in HAE-C1INH patients.

We measured the levels of $\mathrm{C} 1 \mathrm{INH}$ in complex with activated contact factors in plasma samples of HAE-C1INH patients $(\mathrm{N}=30,17$ during remission and 13 during acute attack) and healthy controls $(\mathrm{N}=10)$. We did not detect differences in enzyme-inhibitor complexes between samples of controls, patients during remission and patients during an acute attack. Reconstitution with $\mathrm{C} 1 \mathrm{INH}$ did not change this result. Next, we determined the potential to form enzymeinhibitory complexes after complete in vitro activation of the plasma samples with a FXII trigger. In all samples, enzyme-C1INH levels increased after activation, even in patients during an acute attack. However, the levels of FXIla$\mathrm{C} 1 \mathrm{INH}$, FXla-C1INH and kallikrein- $\mathrm{C} 1 \mathrm{INH}$ were at least $52 \%$ lower in samples taken during remission and $70 \%$ lower in samples taken during attack compared to samples from controls $(p<0.05)$. Addition of $\mathrm{C} 1 \mathrm{INH}$ after activation led to an increase in levels of FXIla-C1INH and FXla-C1INH $(p<0.05)$, which were still lower than in controls $(\mathrm{p}<0.05)$, while the levels of kallikrein-C1INH did not change. These results are consistent with constitutive activation and attenuated depletion of the contact system and show that the ongoing activation of the contact system, which is present in $\mathrm{HAE}-\mathrm{C} 1 \mathrm{INH}$ patients both during remission and during acute attacks, is not associated with preferential generation of kallikrein over FXla. 


\section{Introduction}

Hereditary angioedema (HAE) is a rare disorder predominantly caused by reduced levels or activity of $\mathrm{C} 1$-esterase inhibitor $(\mathrm{C} 1 \mathrm{INH})$ due to a mutation in the genes coding for $\mathrm{C} 1 \mathrm{INH}$ (SERPING1). Patients with HAE experience episodic swellings that affect the subcutaneous and submucous tissues at the site of postcapillary venoles. Most common are asymmetrical cutaneous swelling of the hands, feet, face or genitals and swelling of the gastrointestinal tract. Swelling of the respiratory tract is less frequent, but potentially lifethreatening [1]. Acute attacks of angioedema can be treated 1) by replacing $\mathrm{C} 1 \mathrm{INH}$ with the plasma purified or recombinant protein; 2) by the plasma kallikrein inhibitor ecallantide or 3 ) by the specific antagonist of the bradykinin B2 receptor icatibant [1]. There are three types of HAE described: type I and type II are caused by either low levels of $\mathrm{C} 1 \mathrm{INH}$ (type I), or dysfunctional $\mathrm{C} 1 \mathrm{INH}$ (type II) (HAE-C1INH) [1]. Subjects with HAE type III have normal levels and activity of $\mathrm{C} 1 \mathrm{INH}$. In most of these patients the genetic cause of HAE is unknown (HAE-unknown). In one third, a point mutation (Thr328Lys or Thr328Arg) or a deletion (deletion of 72 base pairs: c.971_1018+24del72*) in the coagulation factor XII (FXII) gene is found (HAE-FXII) [2,3]. HAE-C1INH is predominantly and all HAE-FXII are inherited in an autosomal dominant fashion.

$\mathrm{C} 1 \mathrm{INH}$ is a serine protease inhibitor and the main regulator of the classical complement pathway (named to complement $\mathrm{C} 1$ ) and the contact activation system [4]. The contact system, also known as the plasma kallikrein kinin system (PKKS), consists of FXII, prekallikrein and high molecular weight kininogen (HMWK). Activation of the contact system can initiate coagulation via activation of factor $\mathrm{XI}(\mathrm{FXI}) . \mathrm{C} 1 \mathrm{INH}$ is able to rapidly inhibit activated FXII (FXIla), activated FXI (FXla) and kallikrein $[5,6]$. It is the main endogenous inhibitor of FXIla, kallikrein and FXla: more than $90 \%$ of FXIla, $50 \%$ of kallikrein and $50 \%$ of $\mathrm{FXla}$ are inhibited by $\mathrm{C} 1 \mathrm{INH}$ in plasma of healthy persons in in vitro experiments [6-8]. Other inhibitors of the contact system and FXla are: $\alpha_{1}$ antitrypsin (AT) and $\alpha_{2}$-antiplasmin, which both inhibit FXla for $\sim 20-25 \%$ in vitro [8], and $\alpha_{2}$-macroglobulin $\left(\alpha_{2} M\right)$. Approximately $35 \%$ of kallikrein is inhibited by $\alpha_{2} \mathrm{M}$ in vitro, however inhibition by $\mathrm{C} 1 \mathrm{INH}$ is faster than inhibition by $\alpha_{2} \mathrm{M}[6,9]$.

The contact activation system is triggered in vitro when FXII is activated upon binding to negatively charged surfaces, such as dextran sulphate (DXS) or kaolin. Several physiological triggers of FXII have been identified, such as extracellular RNA and long-chain polyphosphates released from bacteria, however their contribution to activation in vivo is not yet clear [10,11]. Binding of 
the proteins of the contact system to endothelial cells initiates FXII-dependent conversion of prekallikrein into kallikrein [12]. FXIla is able to activate both FXI and prekallikrein, HMWK is a nonenzymatic cofactor in these activations. Activation of $\mathrm{FXI}$ starts the intrinsic pathway of coagulation and results in the formation of thrombin and fibrin. Cleavage of prekallikrein by FXIla generates kallikrein, which leads to the generation of bradykinin, via the cleavage of HMWK by kallikrein. Liberated bradykinin is the main mediator of symptoms in patients with HAE. Binding of bradykinin to the bradykinin B2 receptor on endothelial cells activates several intracellular signaling pathways that lead to vasodilatation, increased vascular permeability and fluid efflux $[13,14]$.

During the attack phase of angioedema, activation of the contact system is observed: the levels of cleaved HMWK and FXIla are elevated. The levels of prothrombin fragment 1.2 (a marker of thrombin generation) and D-dimer (a marker of fibrin degradation) are increased as well $[15,16]$. However, thrombotic complications during attacks or increased thrombotic risk in HAE-C1INH patients are not reported. It has been shown that activation of FXII by misfolded protein aggregates in patients with systemic amyloidosis leads to a form of FXIla which activates prekallikrein but not FXI [17]. Hence, in vivo, activation of the kallikrein system without activation of the coagulation system can occur. This led to the hypothesis that in patients with HAE-C1INH, activation of FXII preferentially triggers prekallikrein activation, rather than FXla generation by FXIla.

To test our hypothesis, we measured activation of the contact system as 1) the levels of $\mathrm{C} 1 \mathrm{INH}$ complexed with the activated contact factors in plasma samples, and 2) the in vitro potential of the plasma to form enzyme-inhibitory complexes when the contact system is completely activated. We used two different FXII triggers, with different activation patterns, in separate samples. These measurements were performed in plasma obtained from HAE-C1INH patients during an attack and during remission and were compared with measurements in plasma from healthy controls.

\section{Materials and methods}

\section{$\underline{\text { Patients }}$}

In total, we analyzed 30 samples from patients with HAE-C1INH and 10 samples from healthy controls. These samples were obtained from 17 patients with HAE type I and 1 patient with HAE type II, and from 10 healthy volunteers. 
We examined 13 samples taken during an attack (obtained from 8 different patients) and 17 samples taken during remission from patients with HAE$\mathrm{C} 1 \mathrm{INH}$. From 7 patients we analyzed both samples during attack and during remission.

Blood samples were collected in $3.2 \%$ sodium citrate as anticoagulant. Before blood drawing, the tourniquet was removed. The first $3 \mathrm{ml}$ of blood was discarded. A subset of samples was also collected in an antiprotease mix to prevent activation of the contact system in vitro. The inhibitor cocktail was prepared by dissolving benzamidine $(100 \mathrm{mM})$, hexadimethrine bromide $(400 \mu \mathrm{g} / \mathrm{ml})$, soybean trypsin inhibitor (STI) $(2 \mathrm{mg} / \mathrm{ml})$, leupeptin $(263 \mu \mathrm{M})$ and aminoethylbenzenesulfonylfluoride $(20 \mathrm{mM})$ in acid-citrate-dextrose $(100 \mathrm{mM}$ trisodium citrate, $67 \mathrm{mM}$ citric acid, and $2 \%$ dextrose, $\mathrm{pH} 4.5$ ). Blood was collected in a blood:anticoagulant/inhibitor cocktail ratio of 9:1 [18]. The samples were centrifuged at $2000 \mathrm{~g}$ for $20 \mathrm{~min}$ at room temperature. Aliquots of the plasma samples were immediately snap-frozen in liquid nitrogen and stored at $-80^{\circ} \mathrm{C}$ until use. Blood was collected in the course of routine diagnostic procedures and all patients gave oral informed consent that remaining plasma could be used for research purposes. If consent was given by the patient, the remaining plasma sample was labeled with a code which was documented into a data sheet. The Ethical Committee of the University of Milan approved of this study, also indicating that written informed consent is not necessary if the plasma is obtained during routine diagnostics and that this plasma can be used for research investigating the pathophysiology of hereditary angioedema.

\section{Materials}

Dextran sulfate (DXS; Mr 500 000), ellagic acid, Hepes, STI and polybrene were from Sigma Chemical Co. (St Louis, Mo). The 96-well plates used were Nunc maxisorb (Denmark). Cetor ${ }^{\circledR}$ was from Sanquin (Amsterdam, the Netherlands). The monoclonal antibodies were in house [19]. Normal platelet poor pooled plasma (University Hospital Maastricht) consisted of plasma from 80 healthy volunteers.

The chromogenic assay for the measurement of $\mathrm{C} 1 \mathrm{INH}$ activity was from Technoclone $\mathrm{GmbH}$ (Wien, Austria). Radial immunodiffusion assays for the detection of $\mathrm{C} 1 \mathrm{INH}, \mathrm{C} 1 \mathrm{q}$, and $\mathrm{C} 4$ antigen levels were from Siemens Healthcare Diagnostics (Munich, Germany). The chromogenic peptide kallikrein substrate S-2302 was from Chromogenix, Instrumentation Laboratory (Bedford, USA). For the measurement of cleaved HMWK the goat polyclonal anti-HMWK light chain antibody was from Nordic (Tilburg, the Netherlands) and the biotinylated rabbit 


\section{Chapter 7}

anti-goat antibody and kallikrein from human plasma were from Sigma Aldrich Co. (St Louis, USA).

\section{Handling of the plasma}

Inhibitory complexes were determined both directly in the plasma samples (basal samples) and in the plasma samples upon activation in vitro (activated samples). Furthermore, we reconstituted $\mathrm{C} 1 \mathrm{INH}$ in the plasma samples.

To basal plasma samples we added either Hepes-buffer $(25 \mathrm{mM}$ Hepes, $150 \mathrm{mM} \mathrm{NaCl}, \mathrm{pH}=7.5$ ) or $\mathrm{C} 1 \mathrm{INH}\left(\right.$ cetor $\left.^{\circledR}\right)$, to inhibit free FXla, FXIla and kallikrein if present. The plasma samples were placed for 10 minutes at $37^{\circ} \mathrm{C}$ to allow optimal C1INH complex formation before stop buffer (containing STI and polybrene) was added. For activation of plasma samples we used either ellagic acid or DXS (Mr 500000 ) for $15 \mathrm{~min}$ at $37^{\circ} \mathrm{C}$. After activation of the plasma, we added $\mathrm{C} 1 \mathrm{INH}$ or Hepes-buffer. To stop the reaction, we added stop buffer. Final concentrations of the above reagents were: $20 \%$ plasma, $0.2 \mathrm{U} / \mathrm{ml} \mathrm{C} 1 \mathrm{INH}$, $0.1 \mathrm{mg} / \mathrm{ml}$ ellagic acid, $0.1 \mathrm{mg} / \mathrm{ml} \mathrm{DXS}, 0.03 \%$ polybrene and $0.06 \mathrm{mg} / \mathrm{ml} \mathrm{STI}$. These samples were further diluted in the assay. Incubation of the plasma with ellagic acid or DXS leads to the activation of FXII. FXII activation with ellagic acid leads to activation of prekallikrein and FXI, whereas FXII activation with DXS only leads to activation of prekallikrein and not of FXI.

\section{Laboratory measurements}

The assays for the detection of amidolytic activity of kallikrein in plasma and capacity of plasma to inhibit kallikrein amidolytic activity are based on a method described by Gallimore et al [20] using the chromogenic substrate S-2302. The presence of kallikrein amidolytic activity was measured by diluting the plasma $1: 20$ in $0.05 \mathrm{M}$ Tris, $0.11 \mathrm{M} \mathrm{NaCl}(\mathrm{pH}=7.8)$, incubating it with the chromogenic substrate for 30 minutes at $37^{\circ} \mathrm{C}$ and the rate of release of paranitroaniline (pNA) was measured photometrically at $405 \mathrm{~nm}$. To determine the capacity of plasma to inhibit the amidolytic activity of exogenous kallikrein, a fixed amount $(0.06 \mathrm{U} / \mathrm{ml})$ of purified human plasma kallikrein was added to serial dilution of plasma. The release of pNA was recorded after 5 min incubation at $37^{\circ} \mathrm{C}$ with the substrate. The capacity of plasma to inhibit amidolytic activity of kallikrein was expressed as percentage of normal using a standard curve of normal human pooled plasma.

Cleaved HMWK was evaluated with sodium dodecylsulfate-polyacrylamide gel electrophoresis (SDS PAGE) and immunoblotting analysis, as described previously [21]. 


\section{Enzyme-linked immunosorbent assay (ELISA)}

The levels of $\mathrm{C} 1 \mathrm{INH}$ in complex with FXIla, kallikrein and FXla (FXIla-C1INH, KAL-C1INH, FXla-C1INH) and AT in complex with FXla (FXla-AT) were determined by ELISA as described previously [19]. In short, the monoclonal antibody (mAb) KOK-12 was used as a capture antibody for $\mathrm{C} 1 \mathrm{INH}$ complexed with FXIla or kallikrein. FXIla-C1INH was recognized with the mAbF3 and KAL$\mathrm{C} 1 \mathrm{NH}$ with the mAb K15. The mAb XI-5 was used as a capture mAb for $\mathrm{FXI}(a)$, the mAb R11 recognized FXla-C1INH and the mAb AT-15 recognized FXIa-AT. Absorbance was read at $450 \mathrm{~nm}$ on an EL 808 Ultra microplate reader (Bio-tek Instruments Inc., Winooski, Vt).

Results are expressed in arbitrary units (A.U.) relative to a standard curve obtained from normal pooled plasma maximally activated with DXS (for FXIla$\mathrm{C} 1 \mathrm{NH}$ and KAL-C1INH), or activated with ellagic acid (for all four complexes: FXIIa-C1INH and KAL-C1INH, FXla-C1INH and FXla-AT).

\section{Statistical analysis}

The data are expressed as median [interquartile range (IQR)]. Differences between three or more groups were determined using the Kruskal-Wallis test with Dunn's post hoc test. To determine if addition of $\mathrm{C} 1 \mathrm{INH}$ to samples had an effect on the enzyme-inhibitory complex levels, the Wilcoxon Signed Rank Test was used. Correlations are expressed as Spearman's coefficient. Results were viewed to be statistically significant different when $p<0.05$. Statistical analyses were performed using IBM SPSS Statistics 20 for Windows (Armonk, New York: IBM Corp.) and Prism for Windows 5.00 (GraphPad Software Inc., San Diego, CA, USA).

\section{Results}

The activity of $\mathrm{C} 1 \mathrm{INH}$, which is the main inhibitor of FXII activation and FXIla, is low in plasma samples of HAE-C1INH patients, representing a risk for contact activation during blood drawing and storage. Therefore, we determined if the storage and preservation of plasma samples from patients with HAE-C1INH led to activation of the contact system. We compared samples taken at the same time in citrate alone and in an inhibitor cocktail mixture which efficiently prevents in vitro activation of the contact system [18]. We measured the levels of FXIla$\mathrm{C} 1 \mathrm{INH}$, kallikrein-C1INH and FXla-C1INH in plasma samples obtained from 10 patients and from 10 healthy individuals. Comparison of these levels showed no difference between the two anticoagulants, both for the healthy individuals and 


\section{Chapter 7}

for the HAE-C1INH patients (see Table 7.1). Therefore, low levels of $\mathrm{C} 1 \mathrm{INH}$ in citrated plasma alone did not lead to contact activation after blood drawing and we were able to use plasma samples obtained from citrated blood for our study.

Table 7.1: Comparison of samples taken in citrate and in inhibitor cocktail as anticoagulant

\begin{tabular}{lllll}
\hline & & $\begin{array}{l}\text { FXIla-C1INH } \\
\text { (A.U.) } \\
\text { Median [IQR] }\end{array}$ & $\begin{array}{l}\text { Kallikrein-C1INH } \\
\text { (A.U.) } \\
\text { Median [IQR] }\end{array}$ & $\begin{array}{l}\text { FXla-C1INH } \\
\text { (A.U.) } \\
\text { Median [IQR }]\end{array}$ \\
\hline $\begin{array}{l}\text { HAE-C1INH } \\
\text { patients }\end{array}$ & $\begin{array}{l}\text { Citrate } \\
\text { Inhibitor }\end{array}$ & $0.73[0.62-0.79]$ & $0.5[0.5-0.5]$ & $1.37[1.24-1.42]$ \\
$\begin{array}{l}\text { Healthy } \\
\text { individuals }\end{array}$ & $\begin{array}{l}\text { Citrate } \\
\text { Inhibitor }\end{array}$ & $0.75[0.67-0.79]$ & $0.5[0.5-0.5]$ & $1.28[1.17-1.44]$ \\
\hline & $0.64[0.58-0.68]$ & $0.5[0.5-0.5]$ & $1.26[1.14-1.34]$ \\
\hline
\end{tabular}

IQR: Interquartile range; A.U.: arbitrary units

Study population

Table 7.2 summarizes the main laboratory indices of the study population. The sex distribution was comparable between the groups, however the healthy controls were younger than the patients with HAE-C1INH. The C1INH antigen and activity levels were reduced in patients and consequently, cleaved HMWK and the spontaneous kallikrein activity were increased and the capacity of the plasma to inhibit kallikrein decreased compared to healthy controls.

We did not observe differences in the levels of the enzyme-inhibitory complexes between healthy controls and patients, both in samples taken during remission and in samples taken during an acute attack of angioedema (see Table 7.2). Furthermore, we substituted $\mathrm{C} 1 \mathrm{INH}$ in these plasma samples, and allowed free FXla, FXIla and kallikrein in these samples to form complexes with C1INH. This had no effect on the complex levels determined (data not shown). 
Table 7.2: General characteristics of the study population

\begin{tabular}{|c|c|c|c|}
\hline & $\begin{array}{l}\text { Healthy controls } \\
\text { Median [IQR] }\end{array}$ & $\begin{array}{l}\text { HAE-C1INH } \\
\text { (remission) } \\
\text { Median [IQR] } \\
\end{array}$ & $\begin{array}{l}\text { HAE-C1INH (acute } \\
\text { attack) } \\
\text { Median [IQR] }\end{array}$ \\
\hline N & 10 & 17 & 13 \\
\hline Gender (female) & 9 & 13 & 10 \\
\hline Age (years) & $21[20-21]$ & $48[45-70]$ & $48[47-63]$ \\
\hline C1INH function (\%) & $75.5[69.8-82.5]$ & $11.0[0.0-18.5]$ & $0.0[0.0-5.75]$ \\
\hline C1INH antigen (\%) & $100[90-109]$ & $25.0[25.0-25.0]$ & $9.0[0.0-25.0]$ \\
\hline Cleaved HMWK (\%) & $33.2[30.4-38.0]$ & $47.7[42.2-48.1]$ & $61.8[56.5-70.3]$ \\
\hline $\begin{array}{l}\text { Capacity of the plasma to } \\
\text { inhibit kallikrein (\%) }\end{array}$ & $120.8[111.8-126.5]$ & $56.0[18.6-57.5]$ & $25.5[1.31-34.5]$ \\
\hline $\begin{array}{l}\text { Spontaneous kallikrein } \\
\text { activity (mU/ml) }\end{array}$ & $0.73[0.44-1.89]$ & $6.08[2.15-13.0]$ & $4.34[2.09-16.21]$ \\
\hline FXIla-C1INH (A.U.) & $0.62[0.5-0.65]$ & $0.72[0.62-0.83]$ & $0.67[0.51-0.78]$ \\
\hline Kallikrein-C1INH (A.U.) & $0.5[0.5-0.51]$ & $0.5[0.5-0.5]$ & $0.5[0.5-1.30]$ \\
\hline FXla-C1INH (A.U.) & $1.31[1.20-1.47]$ & $1.40[1.29-1.47]$ & $1.33[1.27-1.44]$ \\
\hline FXla-AT (A.U.) & $0.66[0.5-0.74]$ & $0.83[0.68-0.87]$ & $0.84[0.75-0.97]$ \\
\hline
\end{tabular}

A.U.: arbitrary units; C1INH: C1-esterase inhibitor; HMWK: High molecular weight kininogen; IQR: Interquartile range
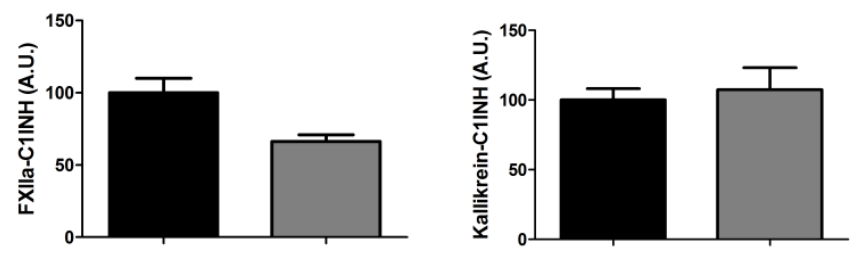

Activation with ellagic acid

$\square$ Activation with DXS
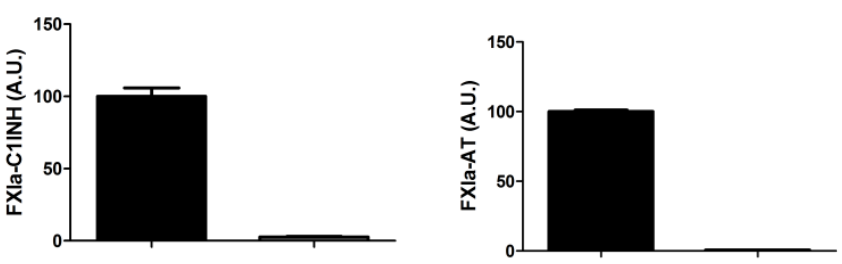

Activation with ellagic acid

Activation with DXS

Figure 7.1. Levels of enzyme-inhibitory complexes in normal pool plasma after activation with ellagic acid or dextran sulphate.

The levels of inhibitory complexes were measured by ELISA after activation of normal pool plasma with either ellagic acid or dextran sulphate (DXS; Mr 500 000). Normal pool plasma was incubated for 25 minutes with either ellagic acid $(0.25 \mathrm{mg} / \mathrm{ml})$ or DXS $(0.25$ $\mathrm{mg} / \mathrm{ml})$ at $37^{\circ} \mathrm{C}$ in Hepes-buffer $(25 \mathrm{mM}$ Hepes, $150 \mathrm{mM} \mathrm{NaCl}, \mathrm{pH}=7.5)$. The reaction was stopped with stop buffer containing STI and polybrene. The volume of plasma was $50 \%$ of total volume during the activation with ellagic acid or DXS, and diluted further in the assay. A.U. = Arbitrary units 


\section{Chapter 7}

Activation of samples from patients

Since we did not observe a difference between the levels of the activated contact factors in complex with their inhibitors in the basal samples, we wanted to determine the potential to form enzyme-inhibitory complexes after complete activation of FXII. We used two different activators of FXII, namely ellagic acid and DXS. Ellagic acid is a potent activator of FXII and is commonly used as a reagent in the activated Partial Thromboplastin Time (aPTT) test. DXS is mainly used in research as a FXII activator [22]. As shown in Figure 7.1, in normal pool plasma activation of FXII with ellagic acid activated both prekallikrein and FXI, whereas FXII activated with DXS only activated prekallikrein and not FXI. Since patients with $\mathrm{HAE}-\mathrm{C} 1 \mathrm{INH}$ have low levels of functional $\mathrm{C} 1 \mathrm{INH}$ we measured the enzyme-inhibitor complexes directly after activation and after addition of $\mathrm{C} 1 \mathrm{INH}$ $(1 \mathrm{U} / \mathrm{ml}$ plasma) to the activated plasma in order to inhibit remaining, free FXIla, kallikrein and FXIa.

\section{Activation with ellagic acid}

Figure 7.2 and Table 7.3 show the levels of the inhibitory complexes in patients with HAE-C1INH and in healthy controls after activation with ellagic acid. The levels of enzyme-C1INH complexes were higher in plasma samples from healthy individuals than in plasma samples of patients, both in those taken during remission and those taken during an acute attack. The levels of FXIla$\mathrm{C} 1 \mathrm{INH}$ and FXla-C1INH increased significantly after addition of $\mathrm{C} 1 \mathrm{INH}$, indicating that not all FXIla and FXla were inhibited after activation with ellagic acid if no additional $\mathrm{C} 1 \mathrm{INH}$ was added. However, the levels of the inhibitory complexes remained lower than those in healthy controls. The levels of kallikrein-C1INH did not increase if $\mathrm{C} 1 \mathrm{INH}$ was added after activation. In comparison with healthy controls, the levels of FXIa-AT after activation with EA were higher in patients during remission and as expected these levels did not change after addition of $\mathrm{C} 1 \mathrm{INH}$. 

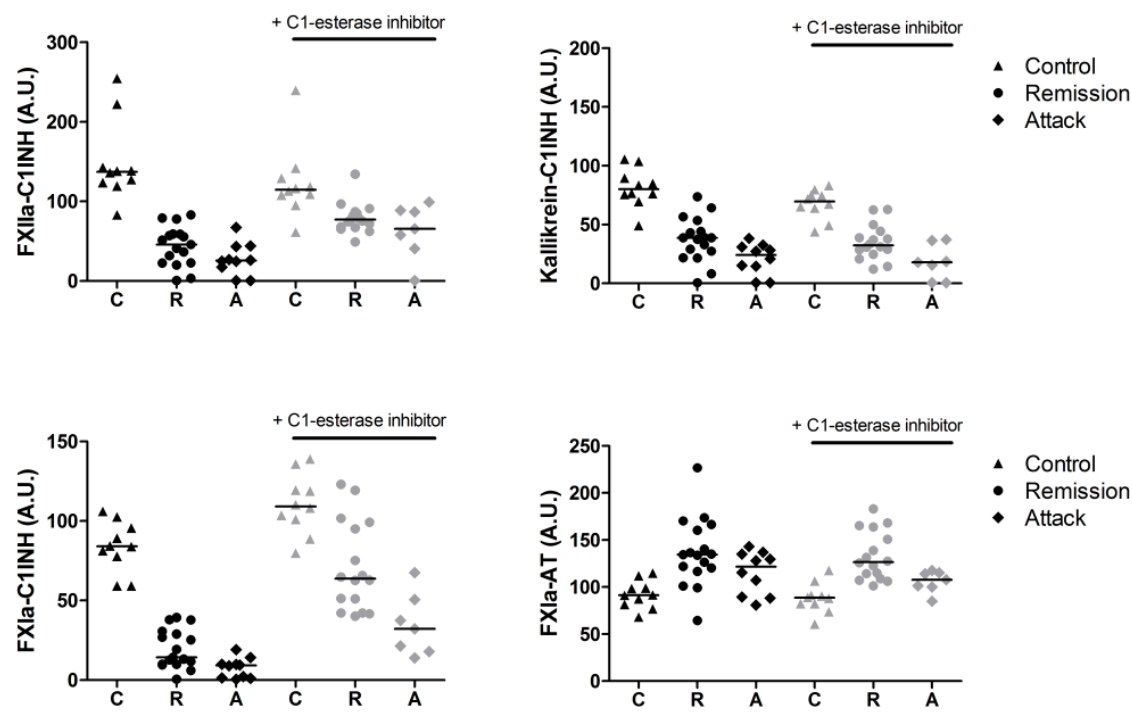

Figure 7.2. Levels of enzyme-inhibitory complexes after activation with ellagic acid from patients and healthy controls.

Levels of enzyme-inhibitory complexes were measured by ELISA in samples from patients with HAE-C1INH and healthy controls after activation with ellagic acid, without (black) and with (grey) addition of $\mathrm{C} 1$-esterase inhibitor $(\mathrm{C} 1 \mathrm{INH})$ after activation. Plasma was activated with ellagic acid $(0.25 \mathrm{mg} / \mathrm{ml})$ for $15 \mathrm{~min}$, than $\mathrm{C} 1 \mathrm{INH}$ or Hepes-buffer $(25$ $\mathrm{mM}$ Hepes, $150 \mathrm{mM} \mathrm{NaCl}, \mathrm{pH}=7.5$ ) was added and after 10 min stop buffer containing STI and polybrene was added. The volume of plasma was $50 \%$ of total volume during the activation with ellagic acid, and diluted further in the assay. Significant differences are indicated in Table 7.3. The lines represent the median value; A.U. = Arbitrary units 
Table 7.3: Levels of enzyme-inhibitory complexes in HAE-C1INH patients and healthy controls after activation with ellagic acid

\begin{tabular}{|c|c|c|c|c|}
\hline & $\begin{array}{l}\text { FXIIa-C1INH } \\
\text { (A.U.) }\end{array}$ & $\begin{array}{l}\text { Kallikrein- } \\
\text { C1INH (A.U.) }\end{array}$ & $\begin{array}{l}\text { FXla-C11INH } \\
\text { (A.U.) }\end{array}$ & FXIa-AT (A.U.) \\
\hline & median [IQR] & median [IQR] & median [IQR] & median [IQR] \\
\hline \multicolumn{5}{|c|}{ No addition of C1-esterase inhibitor } \\
\hline $\begin{array}{l}\text { Healthy controls }(n= \\
10)\end{array}$ & $\begin{array}{l}137.2 \\
{[122.6-162.7]}\end{array}$ & $\begin{array}{l}80.0 \\
{[74.1-93.1]}\end{array}$ & $\begin{array}{l}84.1 \\
{[73.1-97.3]}\end{array}$ & $\begin{array}{l}91.3 \\
{[80.3-102.2]}\end{array}$ \\
\hline $\begin{array}{l}\text { HAE-C1INH } \\
\text { remission }(n=17)\end{array}$ & $\begin{array}{l}45.9 * \\
{[22.8-59.0]}\end{array}$ & $\begin{array}{l}38.7^{*} \\
{[24.6-48.9]}\end{array}$ & $\begin{array}{l}14.3^{*} \\
{[9.9-29.8]}\end{array}$ & $\begin{array}{l}134.5^{*} \\
{[118.4-163.5]}\end{array}$ \\
\hline $\begin{array}{l}\text { HAE-C1INH attack } \\
(n=10)\end{array}$ & $\begin{array}{l}25.5^{*} \\
{[13.3-43.6]}\end{array}$ & $24.1^{*}$ & $\begin{array}{l}9.2^{*} \\
{[1.30-11.0]}\end{array}$ & $\begin{array}{l}121.6 \\
{[89.1-135.6]}\end{array}$ \\
\hline \multicolumn{5}{|c|}{ Addition of C1-esterase inhibitor } \\
\hline $\begin{array}{l}\text { Healthy controls }(n= \\
10)\end{array}$ & $\begin{array}{l}114.7 \\
{[104.6-132.4]}\end{array}$ & $\begin{array}{l}69.7 \\
{[60.3-76.3]}\end{array}$ & $\begin{array}{l}109.2 \\
{[97.9-123.5]}\end{array}$ & $\begin{array}{l}88.6 \\
{[80.0-95.0]}\end{array}$ \\
\hline $\begin{array}{l}\text { HAE-C1INH } \\
\text { remission }(n=16)\end{array}$ & $\begin{array}{l}77.10 * \# \\
{[67.6-86.6]}\end{array}$ & $\begin{array}{l}32.3^{*} \\
{[25.7-42.9]}\end{array}$ & $\begin{array}{l}63.8^{*} \# \\
{[44.4-98.1]}\end{array}$ & $\begin{array}{l}126.6^{*} \\
{[110.3-160.6]}\end{array}$ \\
\hline $\begin{array}{l}\text { HAE-C1INH attack } \\
(\mathrm{n}=7)\end{array}$ & $\begin{array}{l}65.7^{*} \# \\
{[40.7-89.0]}\end{array}$ & $\begin{array}{l}17.9^{*} \\
{[0.6-36.5]}\end{array}$ & $\begin{array}{l}32.2^{*} \# \\
{[17.9-50.5]}\end{array}$ & $\begin{array}{l}107.8 \\
{[100.0-115.1]}\end{array}$ \\
\hline
\end{tabular}

C1INH: C1-esterase inhibitor; HAE: Hereditary angioedema, IQR: interquartile range

* Significant increase or decrease in level of inhibitory complexes compared to healthy controls $(p<0.05)$

\# Significant increase in inhibitory complexes compared to no addition of C1-esterase inhibitor $(p<0.05)$

Since $\mathrm{C} 1 \mathrm{INH}$ is an important inhibitor of kallikrein in vivo, we examined if the capacity of the plasma to inhibit kallikrein and the spontaneous kallikrein activity of the plasma correlate with the levels of kallikrein-C1INH complexes. In activated plasma samples, we observed a positive correlation between the levels of kallikrein- $\mathrm{C} 1 \mathrm{INH}$ and the capacity of the plasma to inhibit kallikrein $(\mathrm{r}=$ $0.85, p<0.001)$, and a negative correlation with the spontaneous kallikrein activity $(r=-0.66, p=0.001)$.

\section{Activation with dextran sulphate}

Next, we activated the plasma samples with DXS (see Figure 7.3 and Table 7.4). Activation of plasma with DXS led to low levels of FXla-C1INH and FXla-AT compared to activation with ellagic acid. The levels of FXla-C1INH were comparable between healthy controls and HAE-C1INH patients. The levels of FXla-AT were higher in HAE-C1INH patients compared to healthy controls, however for both groups the median levels were low (less than 4 A.U. compared to approximately 100 A.U. after activation with ellagic acid). The results for kallikrein-C1INH after activation with DXS were largely comparable to those after activation with ellagic acid. The levels of kallikrein-C1INH were highest in healthy controls, there was no difference in these levels between remission and attack samples. The level of kallikrein-C1INH complexes did not increase after addition of $\mathrm{C} 1 \mathrm{INH}$ after activation of the plasma. The levels of 
FXIla-C1INH were highest in healthy controls and this was significant if no $\mathrm{C} 1 \mathrm{INH}$ was added after activation. Addition of $\mathrm{C} 1 \mathrm{INH}$ increased the levels of FXIla-C1INH in HAE-C1INH patients. Due to this there was no difference in FXIla-C1INH levels between healthy controls and HAE-C1INH patients.
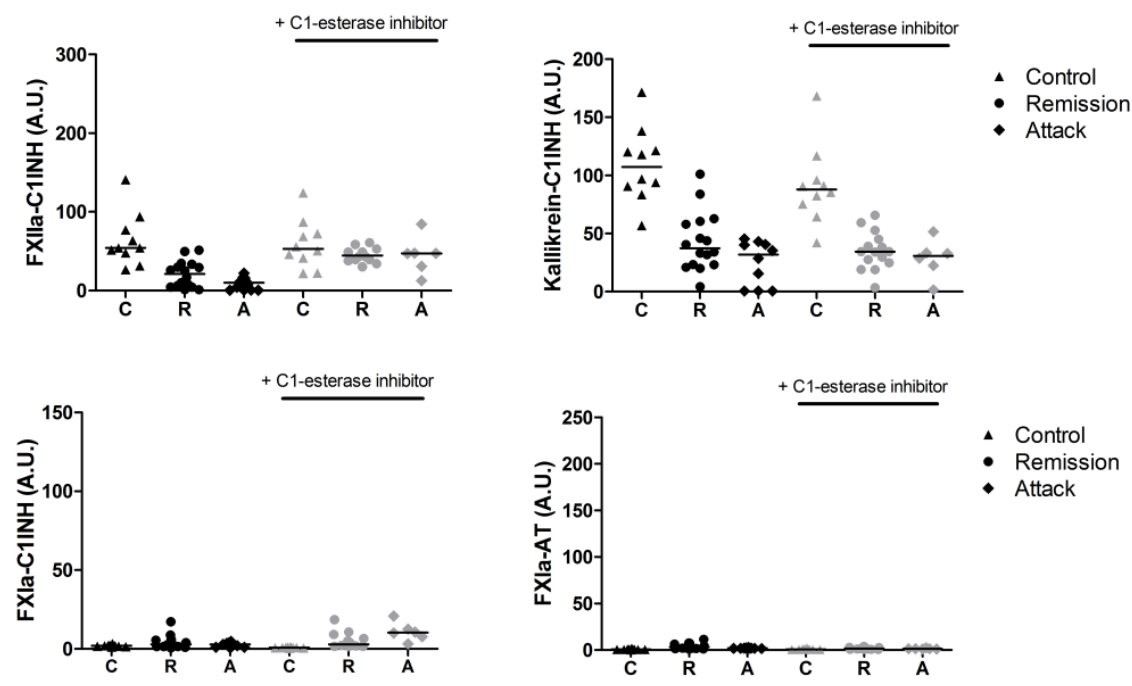

Figure 7.3. Levels of enzyme-inhibitory complexes after activation with dextran sulphate from patients and healthy controls.

Levels of enzyme-inhibitory complexes were measured by ELISA in samples from patients with $\mathrm{HAE}-\mathrm{C} 1 \mathrm{INH}$ and healthy controls after activation with dextran sulphate (DXS; Mr 500 000), without (black) and with (grey) addition of C1-esterase inhibitor $(\mathrm{C} 1 \mathrm{INH})$ after activation. Plasma was activated with DXS $(0.25 \mathrm{mg} / \mathrm{ml})$ for $15 \mathrm{~min}$, than $\mathrm{C} 1 \mathrm{INH}$ or Hepes-buffer $(25 \mathrm{mM}$ Hepes, $150 \mathrm{mM} \mathrm{NaCl}, \mathrm{pH}=7.5$ ) was added and after 10 min stop buffer containing STI and polybrene was added. The volume of plasma was $50 \%$ of total volume during the activation with DXS, and diluted further in the assay. Significant differences are indicated in Table 7.4. The lines represent the median value; A.U. = Arbitrary units 
Table 7.4: Levels of enzyme-inhibitory complexes in HAE-C1INH patients and healthy controls after activation with dextran sulphate (Mr 500000$)$

\begin{tabular}{|c|c|c|c|c|}
\hline & $\begin{array}{l}\text { FXIIa-C1INH } \\
\text { (A.U.) }\end{array}$ & $\begin{array}{l}\text { Kallikrein- } \\
\text { C1INH (A.U.) }\end{array}$ & $\begin{array}{l}\text { FXla-C1INH } \\
\text { (A.U.) }\end{array}$ & FXla-AT (A.U.) \\
\hline & median [IQR] & median [IQR] & median [IQR] & median [IQR] \\
\hline \multicolumn{5}{|c|}{ No addition of $\mathrm{C} 1$-esterase inhibitor } \\
\hline $\begin{array}{l}\text { Healthy controls }(n= \\
10)\end{array}$ & $\begin{array}{l}54.1 \\
{[43.7-81.4]}\end{array}$ & $\begin{array}{l}107 \\
{[88.7-125.6]}\end{array}$ & $\begin{array}{l}2.00 \\
{[1.62-2.30]}\end{array}$ & $\begin{array}{l}0.65 \\
{[0.5-0.96]}\end{array}$ \\
\hline $\begin{array}{l}\text { HAE-C1INH } \\
\text { remission }(n=16)\end{array}$ & $\begin{array}{l}21.1^{*} \\
{[4.91-32.4]}\end{array}$ & $\begin{array}{l}37.3^{*} \\
{[23.1-59.8]}\end{array}$ & $\begin{array}{l}2.86 \\
{[1.60-5.19]}\end{array}$ & $\begin{array}{l}3.19 * \\
{[1.64-5.92]}\end{array}$ \\
\hline $\begin{array}{l}\text { HAE-C1INH attack ( } n \\
=10)\end{array}$ & $\begin{array}{l}8.15^{*} \\
{[0.5-13.9]}\end{array}$ & $\begin{array}{l}31.9^{*} \\
{[0.5-41.2]}\end{array}$ & {$[1.06-3.69]$} & $\begin{array}{l}1.90^{*} \\
{[1.66-2.01]}\end{array}$ \\
\hline \multicolumn{5}{|c|}{ Addition of C1-esterase inhibitor } \\
\hline $\begin{array}{l}\text { Healthy controls }(n= \\
10)\end{array}$ & $\begin{array}{l}53.0 \\
{[36.6-76.1]}\end{array}$ & $\begin{array}{l}88.0 \\
{[72.7-101.1]}\end{array}$ & $\begin{array}{l}0.85 \\
{[0.69-1.05]}\end{array}$ & $\begin{array}{l}0.73 \\
{[0.54-0.99]}\end{array}$ \\
\hline $\begin{array}{l}\text { HAE-C1INH } \\
\text { remission }(n=15)\end{array}$ & $\begin{array}{l}44.7 \# \\
{[39.5-52.8]}\end{array}$ & $\begin{array}{l}34.4^{*} \\
{[24.8-45.1]}\end{array}$ & $\begin{array}{l}2.78 * \\
{[1.95-6.50]}\end{array}$ & $\begin{array}{l}1.66^{*} \\
{[0.72-2.53]}\end{array}$ \\
\hline $\begin{array}{l}\text { HAE-C1INH attack ( } n \\
=6 \text { ) }\end{array}$ & $\begin{array}{l}47.0 \# \\
{[26.3-56.7]}\end{array}$ & $\begin{array}{l}30.8^{*} \\
{[17.3-37.8]}\end{array}$ & $\begin{array}{l}10.4^{*} \# \\
{[6.61-14.6]}\end{array}$ & $\begin{array}{l}1.31 \\
{[1.09-1.60]}\end{array}$ \\
\hline
\end{tabular}

C1INH: C1-esterase inhibitor; HAE: Hereditary angioedema, IQR: interquartile range

* Significant increase or decrease in level of inhibitory complexes compared to healthy controls $(p<0.05)$

\# Significant increase in inhibitory complexes compared to no addition of C1-esterase inhibitor $(p<0.05)$

\section{Discussion}

The regulation of the contact system is defective in patients with HAE-C1INH due to a deficiency in $\mathrm{C} 1 \mathrm{INH}$. Activation of the contact system triggers the kinin pathway and, as a consequence, bradykinin formation is poorly controlled. Contact activation may also lead to activation of the intrinsic pathway of coagulation, however, HAE-C1INH patients have no increased tendency to thrombosis. One mechanism may be a preferential generation of bradykinin and less activation of the intrinsic coagulation route, but such mechanisms have not been explored. Therefore, we investigated if contact activation in these patients mainly leads to prekallikrein activation and less to FXI activation.

We determined the activation of the contact system in HAE-C1INH plasma samples by measuring the levels of $\mathrm{C} 1 \mathrm{INH}$ complexed with FXIla, kallikrein and FXla. In accordance with previous findings from Cugno et al. [23], we did not observe a difference in the basal levels of the inhibitory complexes in healthy controls compared to samples of patients with HAE-C1INH during remission. In a study in five Norwegian patients with HAE-C1INH, it was found that the levels of FXla-C1INH and kallikrein-C1INH were comparable during remission and during an attack of angioedema [24]. Our results agree with these findings and 
furthermore we observed that FXIIa-C1INH was not increased during an attack of angioedema in these patients. Since these measurements were performed in plasma with low levels of $\mathrm{C} 1 \mathrm{INH}$, possibly limiting complex formation, we also added $\mathrm{C} 1 \mathrm{INH}$ to the samples before measurement of the enzyme-inhibitory complexes. We have shown that exogenous $\mathrm{C} 1 \mathrm{INH}$ is able to form complexes, however, the addition of $\mathrm{C} 1 \mathrm{INH}$ had no effect on the levels of inhibitory complexes in the basal samples. This indicates that no uninhibited activated contact factors were present in the samples. Other pathways of bradykinin formation exist, however, contact system activation is the main mediator of attacks of angioedema according to literature [25]. Possibly, FXIla was formed but we were unable to measure it because $\mathrm{C} 1 \mathrm{INH}$ cannot (efficiently) inhibit FXIla, when it is bound to endothelial cells [26]. Furthermore, enzyme-C1INH complexes are rapidly cleared from the circulation possibly obscuring differences in complex concentrations [27-29]. Kallikrein- $\alpha_{2} \mathrm{M}$ complexes, which are cleared at a slower rate than kallikrein- $\mathrm{C} 1 \mathrm{INH}$, were found to be increased in a patient with HAE-C1INH during three different acute attacks of angioedema by Kaufman et al [9].

Next, we activated FXII in the plasma samples with two FXII triggers: ellagic acid and dextran sulphate. Activation of FXII with DXS will only activate prekallikrein whereas activation of FXII with ellagic acid leads to activation of both prekallikrein and FXI. The rationale to use DXS was that an in vivo activator with the same properties might mimic the hereditary angioedema phenotype in which bradykinin formation appears to prevail over prothrombotic effects (at least without apparent increased risk of thrombosis). The levels of the inhibitory complexes after activation were highest in the control group for both triggers, as expected, but also increased substantially compared to baseline in the HAE-C1INH patients. This indicates, that even during an acute attack not all plasma $\mathrm{C} 1 \mathrm{INH}$ is consumed in HAE-C1INH, but this is not sufficiently capable to control local bradykinin formation. Activation of plasma with ellagic acid led to substantial lower levels of enzyme-C1INH complexes in plasma of patients with $\mathrm{HAE}-\mathrm{C} 1 \mathrm{INH}$ compared to healthy controls, and these levels remained lower after addition of $\mathrm{C} 1 \mathrm{INH}$ (even though the levels of FXIla-C1INH and FXla$\mathrm{C} 1 \mathrm{INH}$ increased in patients after addition of $\mathrm{C} 1 \mathrm{INH}$ ). On the other hand, the levels of FXla-AT were increased in HAE-C1INH patients compared to healthy controls. Activation of the plasma with DXS, led to larger differences in the levels of kallikrein-C1INH between patients and controls compared to activation of the plasma with ellagic acid. However, the difference in FXIla-C1INH levels between patients and controls was smaller after activation with DXS compared to activation with ellagic acid, and was not statistically significant after addition 
of C1INH. Activation of the plasma with DXS, led to low levels of FXla-inhibitor complexes. Possibly, two different types of FXIla are formed with the different activators. $\alpha-F X I l a$ is able to activate both prekallikrein and FXI (as seen with activation with ellagic acid), whereas $\beta$-FXIla only activates prekallikrein (as seen with activation with DXS). The lower levels of FXIla, FXla and kallikrein in complex with $\mathrm{C} 1 \mathrm{INH}$ after activation of the plasma from HAE-C1INH patients, suggest a reduction in the levels of the zymogens of the contact system. Joseph et al showed that in plasma taken from HAE-C1INH patients during remission, FXII spontaneously activates [30]. FXIla in turn activates prekallikrein and FXI, leading to consumption of these proteins. Since both kallikrein-C1INH and FXla$\mathrm{C} 1 \mathrm{NH}$ were reduced in plasma from patients compared to plasma from controls, activation of FXII during attacks of angioedema in these patients did not predominantly lead to kallikrein formation. This is in contrast to patients with amyloidosis, where activation of FXII leads to the formation of kallikrein-C1INH, without activation of the coagulation system [17]. However, other inhibitors, such as $\alpha_{2}$-macroglobulin for kallikrein and $\alpha_{1}$-antitrypsin for FXla are also present in the plasma. The inhibition of kallikrein by $\alpha_{2} \mathrm{M}$ is slower than inhibition by $\mathrm{C} 1 \mathrm{INH}$, which could explain why the action of this inhibitor is not sufficient in HAE-C1INH patients to prevent attacks [9]. We activated the plasma during 15 min with ellagic acid or DXS, allowing kallikrein- $\alpha_{2} M$ complexes to form. Only after these $15 \mathrm{~min}, \mathrm{C} 1 \mathrm{INH}$ was added to the sample. Therefore, we probably did not see a difference in kallikrein- $\mathrm{C} 1 \mathrm{INH}$ levels before and after addition of $\mathrm{C} 1 \mathrm{INH}$. The fact that activation of FXI in these patients does not lead to an increase in thrombosis, may be due to the action of $\alpha_{1}$-antitrypsin (first described by Heck et al [31]) and other inhibitors of the coagulation enzymes downstream in the cascade. $\mathrm{C} 1 \mathrm{INH}$ inhibits the two key enzymes of the kinin system efficiently: approximately $90 \%$ of FXIla and $50 \%$ of kallikrein are inhibited by $\mathrm{C} 1 \mathrm{INH}$ in vitro, while on the coagulation side it provides approximately $50 \%$ inhibition of FXla, [6-9], but several other proteins control the cascade. The levels of FXla-AT after activation were higher in patients than in healthy controls, highlighting the action of this inhibitor. Thus, even if we could not demonstrate a preferential activation of the kinin system, our data are consistent with the fact that the coagulation pathway is adequately controlled in patients with HAE-C1INH. Furthermore, increased fibrinolysis could protect HAE-C1INH patients during an acute attack against thrombosis. Increased levels of plasmin $\alpha_{2}$-antiplasmin (PAP) complexes have consistently been observed in patients during an acute attack of angioedema $[24,32,33]$.

FXIla independent pathways of formation of bradykinin from HMWK have been demonstrated. Prolylcarboxypeptidase (PRCP) [34] and Heat Shock Protein-90 
(HSP90) [35] can directly activate prekallikrein, in complex with HMWK, bound to endothelial cells, independent from FXII-activation and prekallikrein itself has been shown to acquire enzymatic activity when bound to HMWK sufficient to cleave HMWK [36]. Moreover, recent studies have shown that mannose-binding lectin-associated serine protease - 1 (MASP-1) and to a lesser extent MASP-2, both generated after activation of the complement system, are able to digest HMWK even in the absence of kallikrein. Important to realize for HAE-C1INH patients is that both the activity of MASP-1 and MASP-2 are controlled by $\mathrm{C} 1 \mathrm{NH}$ [37] and MASP-1 and MASP-2 levels are elevated during episodes of stress and infection, known initiators of angioedema episodes.

In conclusion, there was no difference in the basal levels of the enzymeinhibitory complexes between remission and attack samples, indicating that change in contact activation investigated as $\mathrm{C} 1 \mathrm{INH}$ protease complexes was not associated with the attack. We observed lower levels of the inhibitory complexes after complete in vitro activation of FXII in the plasma of HAE-C1INH patients compared to controls. These reduced levels point to lower levels of FXI, FXII and prekallikrein in these plasmas, probably caused by in vivo activation and consumption of these proteins. Since our measurements do not demonstrate preferential activation of the contact over the coagulation system in $\mathrm{HAE}-\mathrm{C} 1 \mathrm{INH}$, the apparent absence of thrombotic complications during angioedema attacks is probably due to other regulatory mechanisms controlling the coagulation cascade (inhibitors of active coagulation factors) or increased fibrinolysis which compensates for the increase in coagulation. Consumption of $\mathrm{C} 1 \mathrm{INH}$ in HAE-C1INH patients leads to an unstable equilibrium. Since $\mathrm{C} 1 \mathrm{INH}$ controls several systems that influence bradykinin formation, any factor that contributes to an increase in bradykinin formation, such as activation of the contact system or MASP-1 or MASP-2, could cause an attack of angioedema.

\section{Acknowledgements}

This work was supported by the Netherlands Heart Foundation (grant 2008B120). We thank Dr. C Nieuwhof and Dr. J Damoiseaux (Maastricht University Medical Centre) for providing patient material for the pilot experiments and we thank L Maggioni (University of Milan) who assisted with the performance of the experiments. 


\section{References}

1. Longhurst $\mathrm{H}$, Cicardi $\mathrm{M}$. Hereditary angio-oedema. Lancet. 2012; 379: 474-81.

2. Dewald G, Bork K. Missense mutations in the coagulation factor XII (Hageman factor) gene in hereditary angioedema with normal C1 inhibitor. Biochem Biophys Res Commun. 2006; 343: 1286-9.

3. Bork K, Wulff K, Meinke P, Wagner N, Hardt J, Witzke G. A novel mutation in the coagulation factor 12 gene in subjects with hereditary angioedema and normal C1inhibitor. Clin Immunol. 2011; 141: 31-5.

4. Zeerleder S. C1-inhibitor: more than a serine protease inhibitor. Semin Thromb Hemost. 2011; 37: 362-74.

5. Forbes CD, Pensky J, Ratnoff OD. Inhibition of activated Hageman factor and activated plasma thromboplastin antecedent by purified serum C1 inactivator. J Lab Clin Med. 1970; 76: 809-15.

6. van der Graaf F, Keus JF, Koedam JA, Rietveld A, Bouma BN. Prekallikrein activation and kallikrein inactivation in human plasma. Adv Exp Med Biol. 1983; 156: $143-8$.

7. Pixley RA, Schapira M, Colman RW. The regulation of human factor XIla by plasma proteinase inhibitors. J Biol Chem. 1985; 260: 1723-9.

8. Wuillemin WA, Minnema M, Meijers JC, Roem D, Eerenberg AJ, Nuijens JH, ten Cate $\mathrm{H}$, Hack $\mathrm{CE}$. Inactivation of factor Xla in human plasma assessed by measuring factor Xla-protease inhibitor complexes: major role for C1-inhibitor. Blood. 1995; 85: 1517-26.

9. Kaufman N, Page JD, Pixley RA, Schein R, Schmaier AH, Colman RW. Alpha 2macroglobulin-kallikrein complexes detect contact system activation in hereditary angioedema and human sepsis. Blood. 1991; 77: 2660-7.

10. Kannemeier C, Shibamiya A, Nakazawa F, Trusheim H, Ruppert C, Markart P, Song Y, Tzima E, Kennerknecht E, Niepmann M, von Bruehl ML, Sedding D, Massberg S, Gunther A, Engelmann B, Preissner KT. Extracellular RNA constitutes a natural procoagulant cofactor in blood coagulation. Proc Natl Acad Sci U S A. 2007; 104: 6388-93.

11. Smith SA, Choi SH, Davis-Harrison R, Huyck J, Boettcher J, Rienstra CM, Morrissey $\mathrm{JH}$. Polyphosphate exerts differential effects on blood clotting, depending on polymer size. Blood. 2010; 116: 4353-9.

12. Joseph K, Shibayama Y, Ghebrehiwet B, Kaplan AP. Factor XII-dependent contact activation on endothelial cells and binding proteins $\mathrm{gC} 1 \mathrm{qR}$ and cytokeratin 1. Thromb Haemost. 2001; 85: 119-24.

13. Oschatz C, Maas C, Lecher B, Jansen T, Bjorkqvist J, Tradler T, Sedlmeier R, Burfeind P, Cichon S, Hammerschmidt S, Muller-Esterl W, Wuillemin WA, Nilsson G, Renne T. Mast cells increase vascular permeability by heparin-initiated bradykinin formation in vivo. Immunity. 2011; 34: 258-68.

14. Bossi F, Fischetti F, Regoli D, Durigutto P, Frossi B, Gobeil F, Jr., Ghebrehiwet B, Peerschke El, Cicardi M, Tedesco F. Novel pathogenic mechanism and therapeutic approaches to angioedema associated with $\mathrm{C} 1$ inhibitor deficiency. J Allergy Clin Immunol. 2009; 124: 1303-10 e4.

15. Cugno M, Zanichelli A, Bellatorre AG, Griffini S, Cicardi M. Plasma biomarkers of acute attacks in patients with angioedema due to $\mathrm{C} 1$-inhibitor deficiency. Allergy. 2009; 64: 254-7.

16. Cugno M, Cicardi M, Bottasso B, Coppola R, Paonessa R, Mannucci PM, Agostoni A. Activation of the coagulation cascade in C1-inhibitor deficiencies. Blood. 1997; 89: 3213-8. 
17. Maas C, Govers-Riemslag JW, Bouma B, Schiks B, Hazenberg BP, Lokhorst HM, Hammarstrom P, ten Cate H, de Groot PG, Bouma BN, Gebbink MF. Misfolded proteins activate factor XII in humans, leading to kallikrein formation without initiating coagulation. J Clin Invest. 2008; 118: 3208-18.

18. Scott CF, Shull B, Muller-Esterl W, Colman RW. Rapid direct determination of low and high molecular weight kininogen in human plasma by Particle Concentration Fluorescence Immunoassay (PCFIA). Thromb Haemost. 1997; 77: 109-18.

19. Govers-Riemslag JW, Smid M, Cooper JA, Bauer KA, Rosenberg RD, Hack CE, Hamulyak K, Spronk HM, Miller GJ, ten Cate H. The plasma kallikrein-kinin system and risk of cardiovascular disease in men. J Thromb Haemost. 2007; 5: 1896-903.

20. Gallimore MJ, Friberger P. Simple chromogenic peptide substrate assays for determining prekallikrein, kallikrein inhibition and kallikrein "like" activity in human plasma. Thromb Res. 1982; 25: 293-8.

21. Cugno M, Cicardi M, Coppola R, Agostoni A. Activation of factor XII and cleavage of high molecular weight kininogen during acute attacks in hereditary and acquired C1-inhibitor deficiencies. Immunopharmacology. 1996; 33: 361-4.

22. Loiseau C, Randriamahazaka HN, Nigretto JM. Explicit constants for the dextransulfate-mediated activation and autoactivation of purified human factor XII (Hageman factor). Eur J Biochem. 1996; 239: 692-701.

23. Cugno M, Nuijens J, Hack E, Eerenberg A, Frangi D, Agostoni A, Cicardi M. Plasma levels of $\mathrm{C} 1$ - inhibitor complexes and cleaved $\mathrm{C} 1$ - inhibitor in patients with hereditary angioneurotic edema. J Clin Invest. 1990; 85: 1215-20.

24. Nielsen EW, Johansen HT, Hogasen K, Wuillemin W, Hack CE, Mollnes TE. Activation of the complement, coagulation, fibrinolytic and kallikrein-kinin systems during attacks of hereditary angioedema. Scand J Immunol. 1996; 44: 185-92.

25. Davis AE, 3rd. Hereditary angioedema: a current state-of-the-art review, III: mechanisms of hereditary angioedema. Ann Allergy Asthma Immunol. 2008; 100: S7-12.

26. Schousboe I. Binding of activated Factor XII to endothelial cells affects its inactivation by the C1-esterase inhibitor. Eur J Biochem. 2003; 270: 111-8.

27. de Smet BJ, de Boer JP, Agterberg J, Rigter G, Bleeker WK, Hack CE. Clearance of human native, proteinase-complexed, and proteolytically inactivated $\mathrm{C} 1$-inhibitor in rats. Blood. 1993; 81: 56-61.

28. Wuillemin WA, Bleeker WK, Agterberg J, Rigter G, ten Cate H, Hack CE. Clearance of human factor Xla-inhibitor complexes in rats. Br J Haematol. 1996; 93: 950-4.

29. Nuijens JH, Huijbregts CC, Eerenberg-Belmer AJ, Abbink JJ, Strack van Schijndel RJ, Felt-Bersma RJ, Thijs LG, Hack CE. Quantification of plasma factor XIla-Cl(-)inhibitor and kallikrein-Cl(-)-inhibitor complexes in sepsis. Blood. 1988; 72: 1841-8.

30. Joseph K, Tuscano TB, Kaplan AP. Studies of the mechanisms of bradykinin generation in hereditary angioedema plasma. Ann Allergy Asthma Immunol. 2008; 101: 279-86.

31. Heck LW, Kaplan AP. Substrates of Hageman factor. I. Isolation and characterization of human factor XI (PTA) and inhibition of the activated enzyme by alpha 1-antitrypsin. J Exp Med. 1974; 140: 1615-30.

32. Nilsson T, Back O. Elevated plasmin-alpha 2-antiplasmin complex levels in hereditary angioedema: evidence for the in vivo efficiency of the intrinsic fibrinolytic system. Thromb Res. 1985; 40: 817-21.

33. van Geffen M, Cugno M, Lap P, Loof A, Cicardi M, van Heerde W. Alterations of coagulation and fibrinolysis in patients with angioedema due to $\mathrm{C} 1$-inhibitor deficiency. Clin Exp Immunol. 2012; 167: 472-8. 


\section{Chapter 7}

34. Shariat-Madar Z, Mahdi F, Schmaier AH. Identification and characterization of prolylcarboxypeptidase as an endothelial cell prekallikrein activator. J Biol Chem. 2002; 277: 17962-9.

35. Joseph K, Tholanikunnel BG, Kaplan AP. Heat shock protein 90 catalyzes activation of the prekallikrein-kininogen complex in the absence of factor XII. Proc Natl Acad Sci U S A. 2002; 99: 896-900.

36. Joseph K, Tholanikunnel BG, Kaplan AP. Factor XII-independent cleavage of highmolecular-weight kininogen by prekallikrein and inhibition by $\mathrm{C} 1$ inhibitor. J Allergy Clin Immunol. 2009; 124: 143-9.

37. Dobo J, Major B, Kekesi KA, Szabo I, Megyeri M, Hajela K, Juhasz G, Zavodszky $P$, Gal P. Cleavage of kininogen and subsequent bradykinin release by the complement component: mannose-binding lectin-associated serine protease (MASP)-1. PLoS One. 2011; 6: e20036. 


\section{Chapter 8}

Novel insights in genetics of arterial thrombosis

J. Konings, J.W.P. Govers-Riemslag, H. ten Cate

This review was originally published as a book chapter in Clinical cardiogenetics. (C) Springer-Verlag London Limited 2011. 



\section{Introduction}

The vast majority of arterial thrombotic complications develop either on top of an atherosclerotic lesion, or as thromboemboli originating in the heart, mostly related to atrial fibrillation. The origin of these two entities is quite distinct. Whereas atherothrombosis is largely dependent on vessel wall characteristics (plaque lesion size and composition), emboli from the heart are more dependent on flow and blood composition characteristics. In all cases, the three components that were indicated by Rudolph Virchow: abnormalities in the blood flow, hypercoagulability of the blood and injury to the vessel wall, are operational and there is no black and white distinction between the different mechanisms of thromboembolic disease.

The involvement of the blood coagulation system in atherothrombosis as well as atrial fibrillation is evident from the efficacy of antithrombotic medication. Whereas platelet inhibitors are particularly effective in preventing atherothrombotic complications such as myocardial infarction, plasmatic coagulation inhibition is an effective pharmacological intervention in patients with atrial fibrillation. These differences in efficacy of medication also point to the different weight of blood coagulation components in the pathophysiology of arterial thrombosis. In this chapter we discuss the contributing role of the blood coagulation mechanism to arterial thromboembolism from a genetic perspective. While the relationship between genetics and venous thrombosis has been extensively studied, this is less so in arterial thrombosis. Still, the coagulation genotype may contribute to thrombosis risk as recently established in a large meta-analysis showing that factors that are considered specific for venous thrombosis, such as factor $\mathrm{V}$ Leiden, also contribute to the risk of myocardial infarction [1]. In atrial fibrillation there have been several studies clearly demonstrating an independent association between coagulation activity (e.g. D-dimer levels) and thromboembolic risk [2]. Hence, it is likely that the genetic influence of determinants of coagulation may also be of importance in embolic stroke.

There is another reason for looking at the interaction between (genetic) coagulation activity and arterial thrombosis: several lines of evidence indicate that hypercoagulability and in particular thrombin generation are linked to atherosclerosis [3,4]. It is likely that also genetic determinants of coagulation contribute to atherogenesis and may even influence plaque phenotype, such that the risk of a thrombotic event is changed.

The genotype may affect concentration and/or activity of a coagulation protein, or may have no apparent effect at all. Some genetic variations, such as those 
underlying hemophilia $A$, have a major inhibitory impact on blood coagulation; others, like factor $V$ Leiden have very limited coagulation enhancing effects. Thus, the direction and severity of the biological effects on coagulation, hence on thrombosis, may vary considerably, depending on the specific genetic variation.

\section{Hemostatic system}

The primary role of the hemostatic system is to confine bleeding without causing thrombotic complications. This system consists of platelets, coagulation and fibrinolysis. Platelet activation and coagulation are complementary processes. Platelets provide a procoagulant surface and additional coagulation proteins, whereas thrombin, a product of coagulation, is one of the most potent platelet activators. Furthermore, fibrin fibers stabilize the platelet aggregate to form a hemostatic plug and prevent blood loss.

Upon injury to the vessel wall, platelets adhere to the site of trauma and form an aggregate which serves as a primary plug that stops bleeding [5]. Adhesion of platelets is characterized by several stages: tethering, rolling, activation and stable adhesion. Receptor-ligand interactions mediate the adhesion and activation of platelets. Platelets express a high density of receptors on their membrane surface. The platelet receptors interact with ligands expressed on the surface of endothelial cells, within the subendothelial matrix or as soluble proteins in the circulation [6], see Figure 8.1.

During tethering, the interaction of platelets with the subendothelium is dependent on flow conditions. Blood flowing in a vessel generates stress forces, called shear stress. Low shear stress is present in veins and larger arteries, whereas high shear stress is especially found in the microvasculature and at places of stenosis [7]. At high shear rates, von Willebrand Factor (VWF) is essential to bridge the receptors on the platelet membrane and components in the vessel wall such as collagen: the glycoprotein (GP) Ib-IX-V receptor on platelets adheres to immobilized vWF bound to collagen in the vessel wall. This interaction is quite unstable, but allows GPVI and GPla/lla (integrin $\alpha_{2} \beta_{1}$ ) to interact with collagen in the subendothelium. Furthermore, these interactions activate the GPIlb/llla (integrin $\alpha \mathrm{llb} / \beta 3$ ) receptor which binds to vWF and fibrinogen. These interactions allow stable platelet adhesion [8]. At low shear rates, vWF is not essential for platelet adhesion, other receptors such as GPIa/lla and GPVI mediate the adhesion of platelets to the vessel wall [9]. 


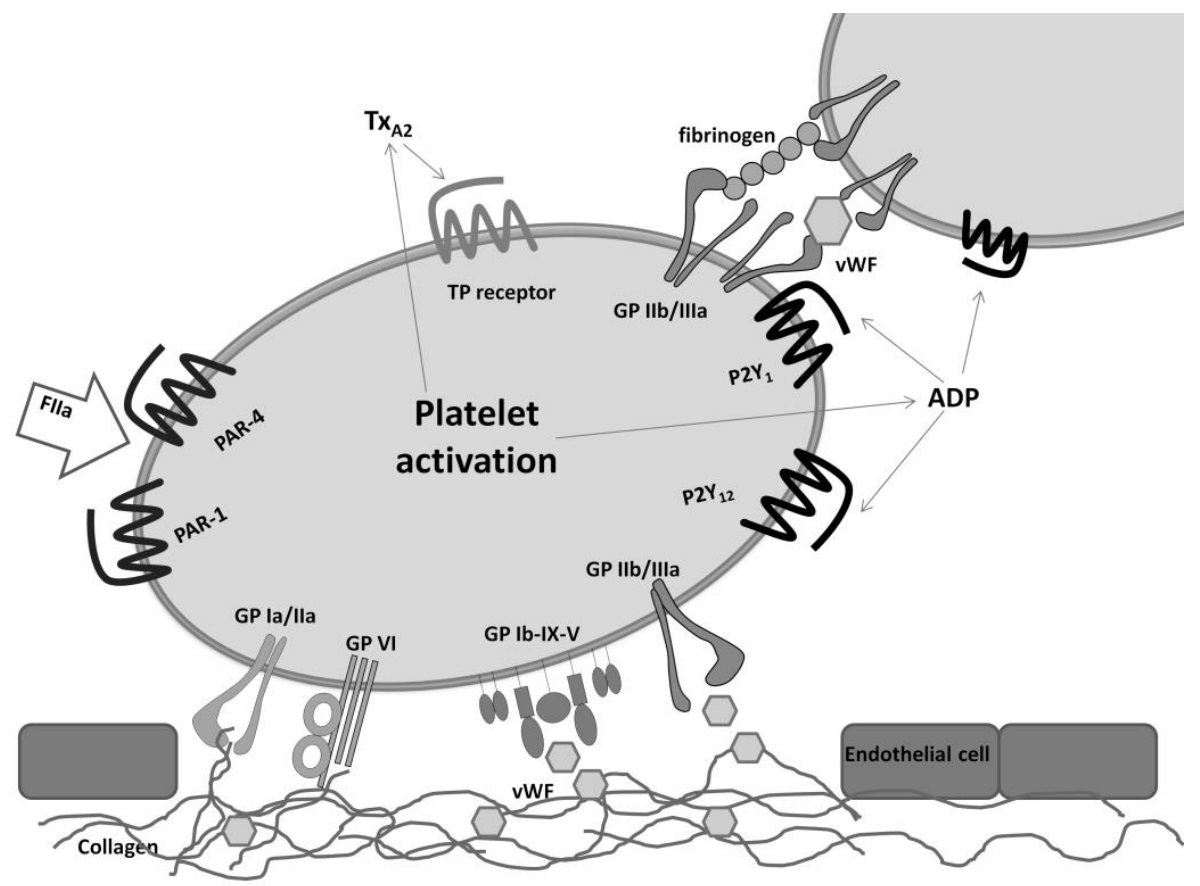

Figure 8.1: Platelet and its receptors

Platelets express several receptors, which are important for platelet adhesion, activation and aggregation. The GPIb-IX-V receptor is essential for platelet adhesion under high shear conditions. The GPIba subunit interacts with von Willebrand factor (vWF) in the exposed subendothelium. This is an unstable interaction, but allows the more stable adhesion of the GPla/lla receptor and the GPVI receptor to collagen in the exposed subendothelium. Platelets are activated by the interaction of these receptors with their ligand and the binding of several agonists to platelet receptors. Thrombin is one of the most powerful platelet activating agonists. Activation of platelets via thrombin is mediated by proteinase-activated receptor (PAR)-1 and PAR-4. Activated platelets release ADP which binds to the $P 2 Y_{1}$ and $P 2 Y_{12}$ receptors and produce thromboxane $A 2$ (TXA2) which binds to thromboxane receptors (TP). The main receptor involved in platelet aggregation is GPIIb/Illa, binding of this receptor to vWF or fibrinogen bridges between platelets.

GP: glycoprotein; PAR: proteinase-activated receptor; TP: thromboxane receptor; TXA2: thromboxane A2; vWF: von Willebrand factor.

After adhesion, platelets are activated. Several activation pathways exist, all requiring platelet receptors. Agonist activating platelets include collagen, adenosine diphosphate (ADP), serotonin, thromboxane $A 2$ and thrombin. Upon platelet activation, $\mathrm{ADP}$, serotonin, $\mathrm{Ca}^{2+}$ ions and several proteins such as fibrinogen, vWF and coagulation factors are secreted by the platelet. Furthermore, thromboxane A2 is formed by the platelet. ADP is able to activate platelets via the $P 2 Y_{1}$ and the $P 2 Y_{12}$ receptors, thromboxane $A 2$ via the 


\section{Chapter 8}

thromboxane receptor. Thrombin, a key enzyme in blood coagulation, is an important platelet activator. Platelet activation via thrombin involves two protease-activated receptors (PAR), PAR-1 and PAR-4, and triggers platelet secretion and aggregation. The main receptor involved in aggregation is GPIlb/Illa, this receptor assists in the mutual interaction of platelets and between platelets and other substrates. These substrates include fibrinogen and VWF, they help to bridge between platelets. Platelet aggregates are an essential constituent of the arterial thrombus. The second critical role of platelets in hemostasis is to expose a platform for activation of coagulation proteins. Phosphatidylserine provides a procoagulant surface for the assembly of enzymatic complexes of coagulation factors and promotes thrombin generation. The combination of collagen and thrombin is an effective trigger for a procoagulant response [10].

The proteins of the coagulation system are activated in a cascade of sequentially activated plasma serine proteases (see Figure 8.2). Limited proteolytic activation of the coagulation proteins yields active enzymes and cofactors which catalyze the next reaction in the cascade to form fibrin, the protein that forms the meshwork of the clot. Major coagulation reactions occur at phospholipid surfaces on platelets, particularly after "flip-flop" exposure of phosphatidylserine. The formation of fibrin can be initiated through the initiation of two cascades of the coagulation system: the extrinsic pathway and the intrinsic pathway [11,12].

The extrinsic pathway is triggered by the exposure of tissue factor (TF), constitutively present in the subendothelium, to blood upon vessel injury. TF binds to factor (F) VII(a) and the TF/FVIla complex then cleaves FX into its active form FXa. FXa is a key enzyme common to both the extrinsic and the intrinsic coagulation pathways. FXa associates with FVa onto the exposed procoagulant surface containing phosphatidylserine on platelets via $\mathrm{Ca}^{2+}$-ions to form the enzymatic prothrombinase complex. This prothrombinase complex ( $\mathrm{FXa}, \mathrm{FVa}, \mathrm{Ca}^{2+}$ and phospholipid membrane) converts prothrombin to thrombin. Thrombin, in turn, catalyzes the conversion of fibrinogen to fibrin. Fibrin molecules polymerize to fibers that are covalently linked by FXIIIa [13]. The intrinsic pathway is triggered by activation of FXII on a negative surface in a process called contact activation. The contact activation system consists of four proteins: FXII, FXI, prekallikrein, and high molecular weight kininogen (HMWK). FXIla can either activate FXI into its active form FXla in the presence of the protein cofactor HMWK on a negatively charged surface, which leads to activation of the intrinsic coagulation pathway or can stimulate the kallikreinkinin system (leading to the formation of bradykinin). In the coagulation system 
FXla then converts FIX into FIXa. FIXa associates with cofactor FVIIla into the tenase complex (FIXa, FVIIla, $\mathrm{Ca}^{2+}$ and phospholipid membrane) which in turn activates FX. FXa is the starting point of the common pathway already described above, which will form thrombin after activation of prothrombin (prothrombinase complex). In the last two decades there were two main adaptions of the original cascade/waterfall model. It is now generally accepted that: 1) the TF/FVIla complex not only activates FX but is also able to activate FIX. 2) FXla is not only formed by activation through FXIla, but thrombin can also activate FXI (a positive feedback loop of thrombin). Thrombin plays a key role in coagulation and mediates more procoagulant feedback reactions, including the activation of the cofactors V and VIII, as well as FXIII. Thrombin also initiates an important inhibitory mechanism involving the thrombomodulin mediated activation of protein C by thrombin. Activated protein C (APC) attenuates in concert with the cofactor protein $S$, the intrinsic route of coagulation by the inactivation of the cofactors FVIIla and FVa. Other important natural anticoagulants include antithrombin (which directly inhibits serine proteases such as thrombin) and tissue factor pathway inhibitor (TFPI). The detailed discussion of these systems is beyond the scope of this chapter $[14,15]$.

The fibrinolytic system plays an important role in breaking down cross-linked fibrin clots. The main enzyme responsible for the dissolution of fibrin is plasmin. The inactive zymogen plasminogen is converted to plasmin, mainly by the enzymes tissue type plasminogen activator (tPA) and urokinase plasminogen activator (UPA). This process is enhanced in the presence of fibrin. The fibrinolytic system is inhibited by plasminogen activator inhibitor-1 (PAl-1), thrombin-activatable fibrinolysis inhibitor (TAFI) and $\alpha_{2}$-antiplasmin. PAI-1 is able to inhibit tPA and UPA, TAFI prevents the binding of tPA and plasminogen to fibrin which slows down the conversion of plasminogen into plasmin and plasmin is inhibited by the action of $\alpha_{2}$-antiplamin.

In concert, these complex mechanisms maintain a delicate balance: defects in any of these systems may contribute to a bleeding or clotting (thrombosis) phenotype, depending on the nature and severity of the defect. In the following we specifically address the role of genotypical variation in hemostatic proteins in relation to arterial thromboembolic disease. Most clinical studies that we refer to include coronary artery disease or myocardial infarction as an endpoint; fewer studies addressed stroke and atherosclerosis as major clinical endpoints. 


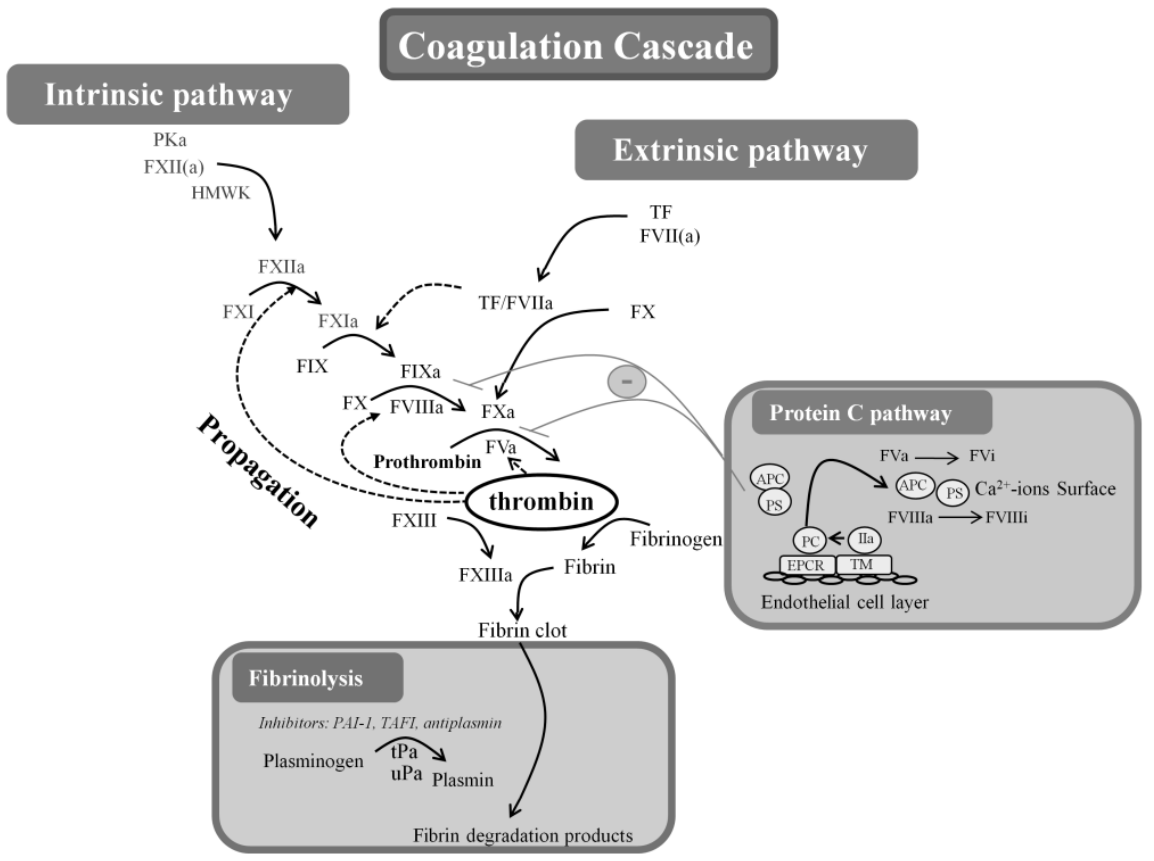

Figure 8.2: Current view of coagulation and related systems.

The coagulation cascade is a sequential activation of coagulation proteins and consists of two pathways initiated by different triggers: the intrinsic pathway and the extrinsic pathway. FXa is the central enzyme common to both the extrinsic and the intrinsic coagulation pathway. After injury, the extrinsic pathway is initiated by the formation of the TF/FVIla complex and cleaves FX to form FXa. The intrinsic pathway is triggered by activation of FXII in a process called contact activation; FXIla will also produce $F X a$ via $\mathrm{FXI}, \mathrm{FIX}$ and $\mathrm{FX}$ activation. FXa associates with $\mathrm{FV}(\mathrm{a})$ on a phospholipid membrane and converts prothrombin (FII) into thrombin. Thrombin will form fibrin out of fibrinogen and will also activate FXIII. FXIIla polymerizes the fibrin fibers. Clot formation is accelerated by activation of the cofactors FV and FVIII and by feedback activation of FXI by thrombin. The TF/FVIla complex can also activate FIX next to FX. Thrombin slows down its own formation by the protein C pathway (see inset). The formed activated protein C (APC) will inactivate the cofactors FVa and FVIlla. After one week the process of fibrinolysis (see inset) will dissolve the fibrin clot.

Roman numerals indicate unactivated coagulation factors, and activated factors are indicated by a lower case "a". Abbreviations: APC: activated protein C; EPCR: endothelial protein C receptor; HMWK: high molecular weight kininogen; PAl-1: plasminogen activator-1; PKa: kallikrein; PS: protein S; TAFI: thrombin-activatable fibrinolysis inhibitor; TF: tissue factor; TM: thrombomodulin; tPa: tissue type plasminogen activator, uPa: urokinase plasminogen activator. 


\section{Platelet-membrane glycoproteins and von Willebrand factor gene polymorphisms}

Current treatment of atherothrombotic complications focuses on the inhibition of platelets. Therefore, one would expect polymorphisms which influence platelet count or the function of platelets or VWF to affect the risk and/or the progression of arterial thrombosis. Many polymorphisms have been identified in platelet receptors, however their contribution to arterial thrombosis seems minor. Polymorphisms in the receptors GPIb-IX-V, GPla/lla, GPIIb/lla and GPVI, and vWF are discussed.

\section{Platelet receptors}

The GPIb-IX-V receptor is crucial for platelet adhesion at places of high shear. It is a complex of four proteins coded by four different genes. GPIb consists of two proteins, GPIba and $\mathrm{Ib} \beta$, linked to each other via a disulfide bridge and noncovalently associated with GPIX and GPV. Especially GPIba is capable of binding to VWF and thrombin. Three polymorphisms have been identified in the gene coding for GPlba. Two of these occur in the coding sequence of the gene and affect the structure of the protein: 1) a $434 \mathrm{C} / \mathrm{T}$ (Thr145Met) substitution $[16,17]$ and 2) a variable number of tandem repeats (VNTR) of 39 base pairs (bp) resulting in four variants with different length termed D, C, B, A $(1,2,3$ or 4 repeats) $[18,19]$. A third polymorphism, a $-5 \mathrm{C} / \mathrm{T}$ substitution, occurs in the Kozak sequence of GPlba gene [20]. This sequence occurs in the promoter region and is essential for efficient protein translation. The C-variant is associated with increased surface level of GPIb-IX-V receptors, the highest expression is found in individuals with the CC genotype [20,21].

Most research has focused on the $-5 \mathrm{C} / \mathrm{T}$ substitution in the promoter region, however the data are inconsistent. The $-5 \mathrm{C}$ allele of $\mathrm{CC}$ genotype was found to be associated with acute coronary syndrome (ACS), thrombotic complications after percutaneous coronary intervention (PCl) [21] and myocardial infarction [22]. In contrast, others did not find any association between this polymorphism and (premature) MI, stroke or coronary artery disease (CAD) [23-26]. A large meta-analysis, including more than 5000 cases and 5000 controls from 14 different studies showed only a marginal, not statistically significant effect on coronary heart disease $(\mathrm{CHD})$ of the $-5 \mathrm{C} / \mathrm{T}$ substitution, with a per-allele relative risk for the $-5 \mathrm{C}$ allele of 1.05 (95\% confidence interval $(\mathrm{Cl}) 0.96-1.13)$ [1]. Pooled analysis indicated that the Kozak sequence $-5 \mathrm{C} / \mathrm{T}$ polymorphism is strongly associated with the risk of ischemic stroke, however the direction of this association is highly variable [27]. The contribution of the VNTR and Thr145Met polymorphisms to arterial thrombosis is not evident, the data from several 


\section{Chapter 8}

clinical studies are inconsistent [16,28-31]. However, meta-analysis did show an increased risk of ischemic stroke for carriers of at least one 145Met-allele [27].

The GPIlb/llla (integrin $\alpha 2 \beta 3$ ) receptor constitutes of two glycoproteins, GPIIla and GPIlb, and is the main receptor involved in aggregation. A common variation is the 1565C/T (Leu33Pro; Leu33: platelet antigen 1 (PIA1), Pro33:PIA2) substitution in exon 2 of the GPIIla gene. $25 \%$ of individuals of Northern European ancestry have the PIA1 variant, with $2 \%$ being homozygous [32]. Biologically, PIA2 positive platelets display a lower threshold for activation, theoretically reducing the thrombosis threshold [33].

Many studies investigated the relation between the Leu33Pro polymorphism and arterial thrombosis, with conflicting results. The PIA2 genotype has been associated with an increased risk of arterial thrombosis and unstable angina or $\mathrm{MI}$, especially in patients younger than 60 [34], sudden cardiac death due to coronary thrombosis [35], and stent thrombosis following catheter-based procedures [36]. The prevalence of the PIA2 allele was increased in siblings of patients with a history of premature ischemic heart disease [37], as well as in subjects with atherothrombotic stroke [31]. However, a substantial number of reports do not confirm the association between arterial disease and the PIA2 genotype [38-44]. Furthermore, the Framingham investigators concluded on the basis of functional testing in combination with genotyping that although heritable factors play a role, the GPIIla genotype only makes a small contribution to platelet aggregation [45]. Several meta-analyses addressed the influence of the PIA2 allele on CAD, with different results. Burr et al. [46] did find an association between the PIA2 allele and CHD, the effect of the polymorphism however differs substantially between study populations. Other meta-analysis did not observe a statistically significant contribution of the PIA2 polymorphism to the risk of MI [43], cerebrovascular disease [44] or $\mathrm{CHD}$ [1].

GPla/lla is a complex of two proteins and assists in platelet adhesion by binding to collagen. The expression of this receptor is subject to high variation, which results in a variable response to collagen [28]. Two silent polymorphisms in the GPla gene, 807C/T (Phe224) and 873G/A (Thr246), are linked and related to the density of this receptor on the platelet surface. The $807 \mathrm{~T} / 873 \mathrm{~A}$ variant is associated with high receptor density, and consequently with a faster rate of platelet adhesion to type I collagen [47]. Conflicting data have been published [48-50], however, meta-analyses did not reveal any significant associations between the polymorphisms and CAD [1,51] or ischemic stroke [52]. 
The structure and function of the collagen receptor GPVI is affected by the 13254T/C (Ser219Pro) substitution [53]. The 13254C-allele was associated with an increased risk of (premature) $\mathrm{Ml}$ and coronary thrombosis [38,53,54], especially in association with the $-148 \mathrm{~T}$ allele of the $\beta$-fibrinogen gene (this polymorphism will be discussed in the section about fibrinogen) indicating an interaction between these genes [53].

\section{Von Willebrand Factor}

The presence of vWF plays an important role in platelet aggregation at sites of high shear, such as coronary plaque lesions. vWF supports the adhesion of platelets to the subendothelium at the site of injury, enhancing platelet aggregation. Furthermore, it acts as a carrier for FVIII, supports local accumulation of FVIII and behaves as an acute phase protein. VWF protein concentration is a marker of cardiovascular risk and VWF levels are elevated in patients with acute coronary syndrome [55]. vWF levels predict CAD in initially healthy individuals, but this association disappears after adjustment for conventional risk factors [55].

Many mutations have been identified in the VWF gene which cause von Willebrand Disease (vWD), an inherited bleeding disorder. In animal studies, pigs and mice with complete vWF deficiency were protected from atherosclerosis [56-59]. In humans, evidence for such a protective effect is less clear. Patients with vWD, or hemophilia A or B, had fewer carotid plaques, a smaller degree of carotid stenosis [60], and a lower number and grade of atherosclerotic plaques of the legs and abdominal aorta [61]. However, the effects appeared to be vascular bed dependent: whereas the intima-media thickness in the femoral artery was minimally reduced, that in the carotid artery was not [62]. In these investigations, however, both patients with hemophilia and VWD were included and the type of hemophilia was not specified. Patients with type 3 VWD (absence of detectable VWF and reduced levels of FVIII) were not protected from the development of early and advanced atherosclerotic lesions [63], although the patient population may have been too young to assess the effect [64]. Type 2B vWD (characterized by a qualitative abnormality in vWF levels) did not protect from atherosclerosis [65].

Several polymorphisms have been identified in the promoter region of the vWF gene: $-1793 \mathrm{G} / \mathrm{C},-1234 \mathrm{C} / \mathrm{T},-1185 \mathrm{~A} / \mathrm{G}$ and $-1051 \mathrm{G} / \mathrm{A}$. These polymorphisms are in strong linkage disequilibrium, resulting in two haplotypes: haplotype 1 (GCAG), and haplotype 2 (CTGA). Homozygotes for haplotype 1 have the highest levels of vWF:antigen (VWF:Ag), homozygotes for haplotype 2 the lowest and heterozygotes intermediate VWF:Ag levels [66,67]. The 


\section{Chapter 8}

Sma I polymorphism, a $T$ to $C$ substitution, is situated in intron 2 of the vWF gene and is not associated with vWF:Ag levels [68]. The 2365A/G (Thr789Ala) polymorphism is associated with increased levels of vWF $[69,70]$. The effect of these polymorphisms is not entirely clear. Haplotype 1 was found to be associated with an increased risk of CAD in subjects with advanced atherosclerosis [71], but not with $\mathrm{MI}$ [72] or CAD in subjects undergoing coronary angiography [73]. The CC genotype of the Sma I polymorphism was associated with higher risk of ischemic stroke, but not with MI [68]. Thr789Ala polymorphism might affect the risk for CHD in type I diabetic patients [69], but not in type 2 diabetes [70], through modulation of the plasma vWF level [69].

Levels of VWF are strongly influenced by blood group: individuals which are carriers of blood groups A, B or AB have mean vWF levels which are $25-30 \%$ higher than carriers of blood group $O$. Carriers of non-O blood group demonstrate an increased risk of arterial thrombosis, most likely due to elevated vWF levels [74].

\section{Coagulation gene polymorphisms}

\section{Initiation of the extrinsic pathway of coagulation}

\section{Factor VII}

The relation between FVII concentration and arterial thrombosis is controversial. Increased levels of FVII zymogen and of levels of FVII clotting activity (FVIIc) have been associated with an increased risk of CAD in the Northwick Park Heart Study-II (NPHS-II) and the Prospective Cardiovascular Münster study (PROCAM) [75,76], but not consistently [77,78]. In these studies, different methods have been used to determine the level of FVII (activated FVII, FVIIc, FVII antigen), possibly explaining some of the discrepancies between these studies [79-81].

Five polymorphic sites of the FVII gene have been described that account for up to $30 \%$ of the variance in FVII levels in plasma [82-90]. These polymorphic sites include: a 10976A/G (Arg353GIn) substitution in the catalytic region, a decanucleotide insertion/deletion (-323ins10) in the promoter region at nucleotide -323 (A1: deletion, A2: insertion); a polymorphism in the hypervariable region 4 (HVR4) of intron 7 with three alleles with different length: $\mathrm{H} 5, \mathrm{H} 6$ and $\mathrm{H} 7$; and two promoter polymorphisms $-401 \mathrm{G} / \mathrm{T}$ and $-402 \mathrm{G} / \mathrm{A}$ [90]. The most studied polymorphisms are the Arg353GIn and -323ins10, the Gln353 and $\mathrm{A} 2$ variants are associated with a reduction in FVII plasma levels of $20 \%$ $25 \%[83,91,92]$. Carriers of the FVII GIn353 have lower FVII levels due to lower 
secretion efficacy of this variant $[84,93]$. The polymorphisms in the promoter region alter the transcriptional activity: the $-401 \mathrm{~T}$ is associated with reduced transcription and reduced levels of FVII, the $-402 \mathrm{~A}$ allele is associated with increased transcriptional activity and higher FVII levels [90]. The $\mathrm{H} 7 \mathrm{H} 7$ genotype is associated with lower FVIIc and FVII antigen levels [94].

Even though there is a strong correlation between the FVII polymorphisms and FVII levels, the relationship with arterial thrombosis is not so clear. Conflicting data are published. The $353 \mathrm{Gln}$ and the -323 ins10 A2 variant and $\mathrm{H} 7 \mathrm{H} 7$ genotype were reported to protect from MI [94-96]. The -402A allele was associated with a higher risk of MI [96]; homozygotes for the Arg353 allele had more complications after $\mathrm{PCl}$ [97]. In contrast, several other studies did not find a significant effect of polymorphisms in the FVII gene on the risk of arterial thrombosis. The WOSCOP (West of Scotland Coronary Prevention) study failed to confirm an association between the Arg353GIn polymorphism and MI [81]. In a Dutch case-control study, patients with the Arg353 variant had a nonsignificant lower risk of $\mathrm{MI}$ [98]. In a large meta-analysis there was no association between CAD and the Arg353GIn polymorphism in the FVII gene [1].

\section{Tissue factor}

Atherosclerotic plaques contain high levels of TF, making them trombogenic. Furthermore, levels of circulating TF are increased in patients with acute coronary syndrome and the expression of TF on monocytes is increased in patients with unstable angina [99].

In the promoter region of the gene coding for TF four polymorphisms (-1812 C/T, -1322 C/T, -1208 deletion/insertion, -603 A/G) have been identified that are in complete linkage disequilibrium and code for two haplotypes: -1208D and -1208 I [99]. The $-1208 \mathrm{D}$ haplotype is associated with lower levels of circulation TF. These haplotypes are in linkage disequilibrium with a 5466A/G polymorphism situated in intron 2 of the TF gene: $-1208 \mathrm{D}$ is linked to $5466 \mathrm{G}$ [100]. The data regarding the association of the polymorphism and disease are contradictory. The -1208 I haplotype has been associated with an increased risk of MI [101], -1208D with an increased risk of cardiac death in patients with acute coronary syndrome [100]. The polymorphism did not influence the risk of CAD or recurrent cardiovascular events in patients with a MI $[99,102]$. 


\section{Chapter 8}

Contact activation and the intrinsic pathway of coagulation

Factor XII

The initiation of the intrinsic pathway via FXII is thought only to occur under pathologic conditions [103], which may involve activators including activated platelets, collagen [104] and polyphosphates [105]. Furthermore, FXII is involved in other biological processes including complement activation and inflammation.

Elevated levels of prekallikrein and HMWK have been associated with $\mathrm{MI}$ $[106,107]$, however little is known about the function of prekallikrein and HMWK in arterial thrombosis. The relation between FXII and arterial thrombosis is not straightforward. In the NPHS-II high levels of FXIla and low levels of FXIla in complex with $\mathrm{C} 1$-esterase inhibitor were associated with increased risk of CHD $[108,109]$. High FXIla levels were also associated with a higher and earlier recurrence rate of ACS in patients who survived a first MI [110] and were positively associated with coronary calcifications [111]. In the Study of Myocardial Infarction Leiden (SMILE), levels of FXIlc were decreased in men that had developed an MI [112], whereas Merlo et al. [106] did not find an effect of the levels of FXIlc in CAD. Furthermore, there are no convincing arguments for an effect in arterial thrombosis of FXII-deficiency [113].

The most investigated polymorphism in the $\mathrm{FXII}$ gene is a $-4 \mathrm{C} / \mathrm{T}$ (previous notation: $46 \mathrm{C} / \mathrm{T}$ ) substitution in the 5'untranslated region. This polymorphism is associated with lower plasma levels of FXII [114].

The association between this polymorphism and arterial thrombosis is not clear. The TT-genotype was associated with an increased risk of CAD in men with high cholesterol [115] and with both CAD and ischemic stroke in the Spanish population [116,117]; however, in patients with pre-existing CAD the TTgenotype had a protective effect on the development of ACS [118]. Furthermore, several studies did not observe an effect of the polymorphism on arterial thrombosis [119-123].

The association of the $-4 \mathrm{C} / \mathrm{T}$ polymorphism and arterial thrombosis is influenced by cholesterol levels. Pravastatin treatment reduced the risk of CAD in men with a CC or CT genotype, but not in men with a TT genotype [115]. Furthermore, in patients with CAD before the age of 45 , the presence of the $-4 T$ allele increased the risk of $\mathrm{MI}$, especially in the presence of hypercholesterolemia. If both risk factors were present, the risk was increased 2.26-fold [124].

Factor XI, factor IX and factor VIII

Both environmental and genetic factors contribute to the levels of circulating FXI, FIX and FVIII. The impact of genetic factors on plasma levels is unclear. 
Even though elevated levels of FXI as well as FIX and FVIII have consistently been associated with $\mathrm{MI}$ and ACS, no polymorphisms have been described which correlate with plasma levels of these factors [89]. While deficiency in FXI is associated with a rather mild bleeding diathesis, deficiency in FIX (hemophilia B) or FVIII (hemophilia A) is associated with a severe bleeding phenotype. Deficiency in FXI may protect against ischemic stroke, the incidence of ischemic stroke was reduced in a cohort of FXI-deficient patients when compared to the general population [125]. In contrast, it did not protect from MI [126]. Deficiency in FIX or FVIII appears to protect against the occurrence of MI: in a long followup study, patients with hemophilia $A$ and $B$ had an $80 \%$ reduction in the risk of fatal ischemic heart disease [127]. Comparison of causes of death in patients with hemophilia in the United States yielded similar results [128]. Female carriers of hemophilia $A$ or hemophilia $B$ also showed a reduced mortality from ischemic heart disease [129]. It is uncertain whether hemophilia $A$ and $B$ have protective properties against ischemic stroke [130].

\section{Common coagulation pathway}

Factor $V$ and prothrombin

The prothrombin $20210 \mathrm{G} / \mathrm{A}$ variant and FV 1691G/A (Arg506Gln; FV Leiden) polymorphisms are relatively common in Caucasian persons with a frequency of $\sim 2$ and $5 \%$ respectively. The biological effect of the prothrombin $20210 \mathrm{G} / \mathrm{A}$ variant results from a higher transcription rate of prothrombin resulting in somewhat higher prothrombin protein concentrations and a higher rate of thrombin generation. The effect of FV Leiden resides in the impaired inactivation of $\mathrm{FVa}$ by activated protein $\mathrm{C}$. These effects have both been characterized as risk factors for venous thrombosis in many studies. In arterial thrombosis however the influence has been more difficult to establish. In the meta-analysis by Ye et al., both variants appear to contribute to the risk of a MI [1]. In contrast, an effect on stroke risk, large or small vessel based has not been detected [131]. However, the effects are small and as single risk factors probably negligible in persons with premature vascular disease without other apparent risk factors [132].

Interestingly, in animal experiments the FV Leiden mutation is associated with an increased burden of atherosclerosis [133,134]. A number of studies indeed suggests that atherosclerosis in the carotid artery is influenced by FV Leiden carriership [135,136], whereas also other prothrombotic gene mutations including the prothrombin $20210 \mathrm{G} / \mathrm{A}$ variant are associated with severity of atherosclerotic burden [137]. One of the mechanisms involved may be an interaction between hypercoagulability and LDL cholesterol transfer to the 


\section{Chapter 8}

vessel wall. Such interactions may contribute to a greater risk of MI $[138,139]$. Thus, although the effects of the polymorphisms as single factors may be very small, the interaction with commonly recognized risk mechanisms for atherosclerosis may give unexpected strong effects on the risks of atherosclerosis and thrombosis, at least in animal models [135].

Finally, the concentration of FV may also play a role in the risk of thrombosis. While carriers of the FV Leiden mutation do not have an altered protein concentration, an increased $\mathrm{FV}$ c level has also been identified as a risk factor for AMI [140]. So far, no genetic basis for elevated FV levels has been published. In contrast, a common R2 haplotype in FV has been shown to lower the FV concentration, but any (protective) effect on arterial thrombosis risk has not been described [141].

\section{Protein $\mathrm{C}$ pathway}

The protein $C$ anticoagulant pathway has antithrombotic activities and limits inflammatory responses. The essential components of this pathway include thrombin, thrombomodulin (TM), the endothelial cell protein $C$ receptor (EPCR), protein $\mathrm{C}$ and protein $\mathrm{S}$. A retrospective cohort study showed that deficiency in protein $S$ or protein $C$ is associated with arterial thrombosis [142].

Thrombomodulin is a transmembrane protein, expressed in endothelial cells. In healthy people, high levels of soluble thrombomodulin (sTM) were associated with a decreased risk of coronary heart disease [143]. However, a crosssectional analysis found a positive association between levels of STM and carotid atherosclerosis. A possible explanation for this difference is that in healthy individuals elevated levels of STM correlated with the expression level of membrane bound TM, whereas in patients with atherosclerotic disease elevated levels indicate damage to the endothelium [144]. Different polymorphisms have been identified in the thrombomodulin gene. Two polymorphisms in the 5'untranslated region, $-133 \mathrm{C} / \mathrm{A}$ and $-33 \mathrm{G} / \mathrm{A}$, are associated with reduced expression of TM [145]. Furthermore, a 127G/A (Ala25Thr) and 1418C/T

substitution have been identified in the TM gene. Polymorphisms in the promoter region of the TM gene were more common in patients diagnosed with MI than in matched controls [146]. The -33A allele has been associated with an increased risk of AMI and carotid atherosclerosis [147-149], however not consistently [150]. In the SMILE the 25Thr allele was associated with MI, especially in young men and in the presence of additional risk factors (such as smoking and the presence of a metabolic risk factor: obesity, hypertension, hypercholesterolemia) [151]. The $455 \mathrm{Val}$ allele was more common in patients with a $\mathrm{MI}$ and in patients with ischemic stroke compared to healthy controls 
$[152,153]$. The Ala455Val predicted the risk of CHD in the black population, however not in the white population. [154]. Other studies failed to find an association [155,156]. TM accelerates the inactivation of the complement factors $\mathrm{C} 3 \mathrm{~b}$ and $\mathrm{C} 5 \mathrm{a}$, through the activation of TAFI by the thrombin-TM complex. Delvaeye et al. [157] identified mutations in the TM gene that impaired the activation of TAFI and therefore were less protected from activated complement.

A polymorphism in the gene coding for EPCR, 6936G/A (Ser219Gly), contributes to a higher basal release of soluble EPCR, causing increased levels of soluble EPCR in plasma. In the NPHS-II, homozygotes for the $219 \mathrm{Gly}$ allele had an increased risk of coronary heart disease [158].

\section{Fibrinogen and factor XIII}

Fibrinogen

The level of fibrinogen has consistently been associated an increased risk for arterial thrombotic disorders. High levels of fibrinogen have been associated with MI, ischemic stroke and peripheral arterial disease [75,159-162]. Fibrinogen levels cluster with other risk markers for arterial thrombosis, such as hypertension, diabetes and smoking [90]. Both genetic and environmental factors influence the levels of circulating fibrinogen. It is estimated that genetic factors account for approximately $20 \%-50 \%$ of variation in fibrinogen levels $[89,163]$. Even though the level of fibrinogen is a risk marker for an arterial thrombotic event, it is not clear if there is a causal relationship [164]. Some authors argue that elevated fibrinogen levels merely reflect the presence of inflammation, atherosclerosis or other risk factors [164].

Several polymorphisms have been identified in the genes that code for the polypeptide chains of fibrinogen. Most interest has been on polymorphisms on the $B \beta$ chain because in vitro studies suggest that the production of the $\beta$ chain is the rate limiting step in the formation of a fibrinogen molecule [90]. Main polymorphisms include the $-148 \mathrm{C} / \mathrm{T},-455 \mathrm{G} / \mathrm{A}$ and $-854 \mathrm{G} / \mathrm{A}$ polymorphisms in the 5' promoter region, the Bcll polymorphism in the 3'region and the Arg448Lys substitution in the $\mathrm{C}$-terminal region in the $\mathrm{B} \beta$ chain, and the Thr312Ala substitution in the $A \alpha$ chain. The rare allele of the $-148 \mathrm{C} / \mathrm{T},-455 \mathrm{G} / \mathrm{A},-854 \mathrm{G} / \mathrm{A}$ and Bcll polymorphisms are associated with higher levels of fibrinogen [90]. The 448Lys allele is associated with a clot with lower permeability and a tighter structure with thinner fibers than the 448Arg variant [165], although this was not confirmed [166]. The Thr312Ala polymorphism is situated near FXIII crosslinking sites, causing increased FXIII cross-linking and formation of thicker fibrin 


\section{Chapter 8}

fibers [167]. This polymorphism is associated with decreased plasma fibrinogen levels [168].

The association between arterial thrombosis and polymorphisms in the fibrinogen genes is not so clear. Even though some studies suggest that there is an association between these polymorphisms and atherosclerosis [169,170], the susceptibility to CAD [171], MI [169,172] and ischemic stroke [168], others did not find an association [168,173,174].

Fibrinogen $\gamma^{\prime}$, an alternative splicing variant of the $Y$-chain of fibrinogen, has been associated with susceptibility to thrombotic disease. A minor fraction of circulating fibrinogen contains the $Y^{\prime}$ chain: $7 \%-15 \%$ circulates as a

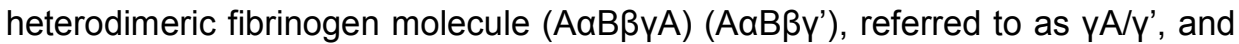

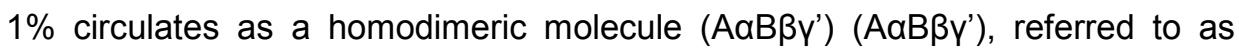
$\gamma^{\prime} / \gamma^{\prime}$. Coronary artery disease has been associated with elevated levels of $\mathrm{YA} / \mathrm{y}^{\prime}$, independent from total fibrinogen levels [166]. Fibrinogen $y^{\prime}$ contains binding sites for thrombin and FXIII. Clots formed from $\mathrm{YA} / \mathrm{y}^{\prime}$ fibrinogen are highly crosslinked, have thinner fibers with more branch points and are more resistant to lysis [175]. Variations in the fibrinogen genes are associated with the level of $y^{\prime}$ and the $y^{\prime} /$ total fibrinogen ratio [176]: the FFG-haplotype $2(\mathrm{H} 2)$ is associated with lower levels of $\mathrm{YA} / \mathrm{Y}^{\prime}$ in plasma; the C-allele of the $9340 \mathrm{~T} / \mathrm{C}$ polymorphism and the G-allele of the 2224G/A polymorphism are associated with higher $\mathrm{Y}^{\prime}$ levels [177].

Mutations in the fibrinogen gene may lead to quantitative and/or qualitative disorders. The quantitative disorders include afibrinogenemia and hypofibrinogenemia and cause reduced levels of circulating fibrinogen. Quantitative disorders are mostly associated with a bleeding diathesis, however arterial thrombosis does occur in these patients [178,179]. Besides its procoagulant activity, fibrin also has antithrombotic properties: it contains nonsubstrate binding places for thrombin. Hereby, fibrin sequesters and down regulates thrombin activity: thrombin is trapped in the clot and is not available for platelet activation in the arterial wall [180]. Qualitative disorders include dysfibrinogenemia and hypodysfibrinogenemia and cause normal or reduced levels of fibrinogen with an abnormal functional activity [180]. Most qualitative disorders are clinically silent, however they can cause a bleeding diathesis, lead to a hypercoagulable state or a combination of bleeding and thromboembolic symptoms. It is believed that there are two mechanisms responsible for thrombosis associated with dysfibrinogenemia: 1) abnormal fibrinogen is defective in binding thrombin resulting in elevated thrombin levels; 2) formed fibrin clots are more resistant to plasmin degradation [181]. Maybe some of 
these effects contribute to incident cases of arterial thrombosis in individuals with dysfibrinogenemia $[182,183]$.

\section{Factor XIII}

Only a few studies addressed the relation between plasma levels of FXIII and CAD, showing inconsistent results [184]. FXIII deficiency is extremely rare (1 in 1-3 million), leads to a bleeding diathesis and may theoretically protect from (arterial) thrombosis [178]. Several polymorphisms have been identified. The most extensively studied polymorphism is the Val34Leu (G163T) substitution in the A subunit. The 34Leu allele enhances the activation of FXIII by thrombin 2-3 fold. This affects the structure of the formed fibrin clot [166]. The Tyr204Phe polymorphism in the A subunits is associated with lower levels and lower activity of FXIII. A polymorphism in the B subunit, His95Arg (A8259G), is associated with an increased dissociation rate of the factor XIII subunits following activation by thrombin [185].

Kohler et al. [186] were the first to find a protective effect of the Leu34 variant for AMI. Several authors confirmed these findings [187-189], however not all $[190,191]$. Two meta-analyses both suggest that the FXIII-A Val34Leu polymorphism exerts a moderate, but statistically significant protective effect against CAD $[192,193]$. The effect of this polymorphism on the risk of ischemic stroke is not clear, it did not influence the risk of peripheral artery disease [184]. In young women the Tyr204Phe polymorphism was associated with a 9-fold increased risk for the occurrence of ischemic stroke. The risk was higher in homozygotes than in heterozygotes, indicating a dose-response relationship [194]. The Arg95 variant alone did not have an effect on the risk for MI, however in the presence of Leu34 variant, the risk for $\mathrm{Ml}$ was reduced in postmenopausal women [195]. The risk for ischemic stroke was not associated with this polymorphism in young women [194]. In patients with non-disabling cerebral ischemia of arterial origin the Arg95 variant was more common in patients with large artery disease compared to patients with small artery disease [131].

\section{Fibrinolytic system}

Fibrinolysis

Based on the functions of the fibrinolytic system, one may postulate important regulatory roles for each of the players in the fibrinolytic cascade. Overall, reduced fibrinolytic activity is associated with increased risk for arterial 


\section{Chapter 8}

thrombosis. However, only for some proteins a clear significance for atherogenesis and arterial thrombosis has been established, although with remaining uncertainties regarding the magnitude of the effects. Plasminogen deficiency does not seem to be a thrombotic risk factor [196]. Elevated levels of circulating tPA have been shown to be associated with arterial thrombosis [197]. This might seem contradictory, however most circulating IPA is bound to PAI-1 and high levels of IPA in plasma could reflect disturbances of the endothelium [197]. No clear associations have been found between tPA-polymorphisms and arterial thrombosis [196]. The $-7531 \mathrm{C} / \mathrm{T}$ substitution and the Alu repeat insertion/deletion (I/D) in the eight intron are associated with changed release rates [198]. The $-7531 \mathrm{C} / \mathrm{T}$ polymorphism was associated with MI [199], but not with ischemic stroke [200]. In the Rotterdam study, the I allele was significantly more present than the D allele in patients with nonfatal MI [201]. However, other studies did not find an association between I/D polymorphism and MI [202,203].

\section{Fibrinolytic inhibitors}

High levels of TAFI antigen and activity have been associated with increased risk of arterial thrombosis in multiple studies [196]. The TAFI plasma levels are determined for approximately $25 \%$ by TAFI gene polymorphisms [204]. Several polymorphisms have been identified among which 1040C/T (Thr325Ile), 505A/G (Ala147Thr) in the coding region and $1542 \mathrm{C} / \mathrm{G}$ in the 3'untranslated region. The 1040TT genotype and the $1542 \mathrm{C}$ allele are associated with lower levels of circulating TAFI [205-207]. Furthermore, the Thr325Ile substitution changes the stability of activated TAFI causing an altered fibrinolytic activity, the fibrinolytic activity is enhanced for the lle325 allele [196]. The 505A/G substitution is associated with increased TAFI levels [208]. These polymorphisms were investigated in several studies, however with inconsistent results [206,209-212]. The clinically most relevant factor in the interplay of fibrinolysis and thrombosis is PAI-1. Concentrations of PAI-1 are an independent risk factor for CAD [213]. There is a common polymorphism known as $4 \mathrm{G} / 5 \mathrm{G}$ in the -675 promoter region. The $5 \mathrm{G}$ allele is slightly less transcriptionally active than the $4 \mathrm{G}$. The PAl-1 4G allele frequency is 0.58 in Caucasians and 0.13 in Africans [214]. PAl-1 levels were strongly dependent on body mass index (BMI), showing highest levels in the highest BMI quartile [215], with BMI being a much stronger determinant of PAl-1 levels than genotype. This metabolic effect is more obvious in African than Caucasian persons, possibly also related to morphometric determinants [214]. The result is that plasma levels are highest in lean persons with a $4 \mathrm{G} / 4 \mathrm{G}$ genotype as compared to the $5 \mathrm{G} / 5 \mathrm{G}$ genotype (about twofold difference in two population based cohorts) [215]. 
Regulation of PAI-1 production is complex. PAI-1 is synthesized in different cell types including hepatocytes, adipocytes and endothelial cells and PAI-1 transcription is regulated by several factors including inflammatory mediators like II-1 and TNFa, as well as hormones like insulin and glucocorticoids and it also acts as an acute phase protein [216]. The contributing effect of the 4G/5G genotype appears at the cellular level, e.g. in the amount of PAl-1 produced under influence of II-1 [217] in vivo. An example is the effect of a diet rich in unsaturated fatty acids, which lowers PAI-1 in $4 \mathrm{G}$ carriers but has no detectable effect in $5 \mathrm{G}$ carriers that have a lower PAl-1 level to begin with [218]. The 4G genotype is also associated with high cholesterol levels [219]. It is likely that the interplay between inflammatory mediators, metabolic factors and PAI-1 genotype, depending on ethnic background, affects fibrinolysis, hence thrombosis risk. In addition to thrombosis, PAl-1 has different modulating effects on the vessel wall including remodeling and atherosclerosis but many of these effects have been quite inconsistent, such that the biological significance remains unclear. Recent data are however challenging, showing that a recombinant PAl-1 based peptide inhibits vasa vasorum and atherogenesis [220] and that overexpressing PAl-1 attenuates aortic aneurysm formation in mice [221].

The clinical effect of the PAI-1 4G/5G genotype has been mainly studied with regard to atherothrombosis and stroke. As a single factor the PAl-1 polymorphism emerged as an independent risk factor for recurrent ischemic events in nonhyperlipidemic post infarction patients, suggesting that in the absence of major risk factors like hypercholesterolemia, the effect of a single genotype can be clinically relevant [222]. This observation deviates from the more commonly held believe that the contribution of one single-nucleotide polymorphism (SNP) in the hemostatic mechanism do not contribute to the risk of arterial thrombosis [223]. The absence of evident risk influence may indeed be much dependent on the population studied. However, also in the pooled analysis of seven hemostatic gene polymorphisms the PAl-1 $4 \mathrm{G}$ variant yielded a per allele relative risk of coronary disease of 1.06 (95\% Cl: $1.02-1.10)$, albeit that a concern remains regarding heterogeneity of the studied populations [1]. As part of a series of common SNP's, PAI-1 4G contributed to risk of AMI in patients with advanced coronary atherosclerosis, suggesting the additive effect of this mutation [224].

With regard to ischemic stroke the evidence for a risk association is highly significant in pooled analysis, but there is a concern of extreme heterogeneity [225]. The most recent meta-analysis does not show any differential effects of PAl-1 genotype with regard to type of stroke (small or large vessel) [226]. 

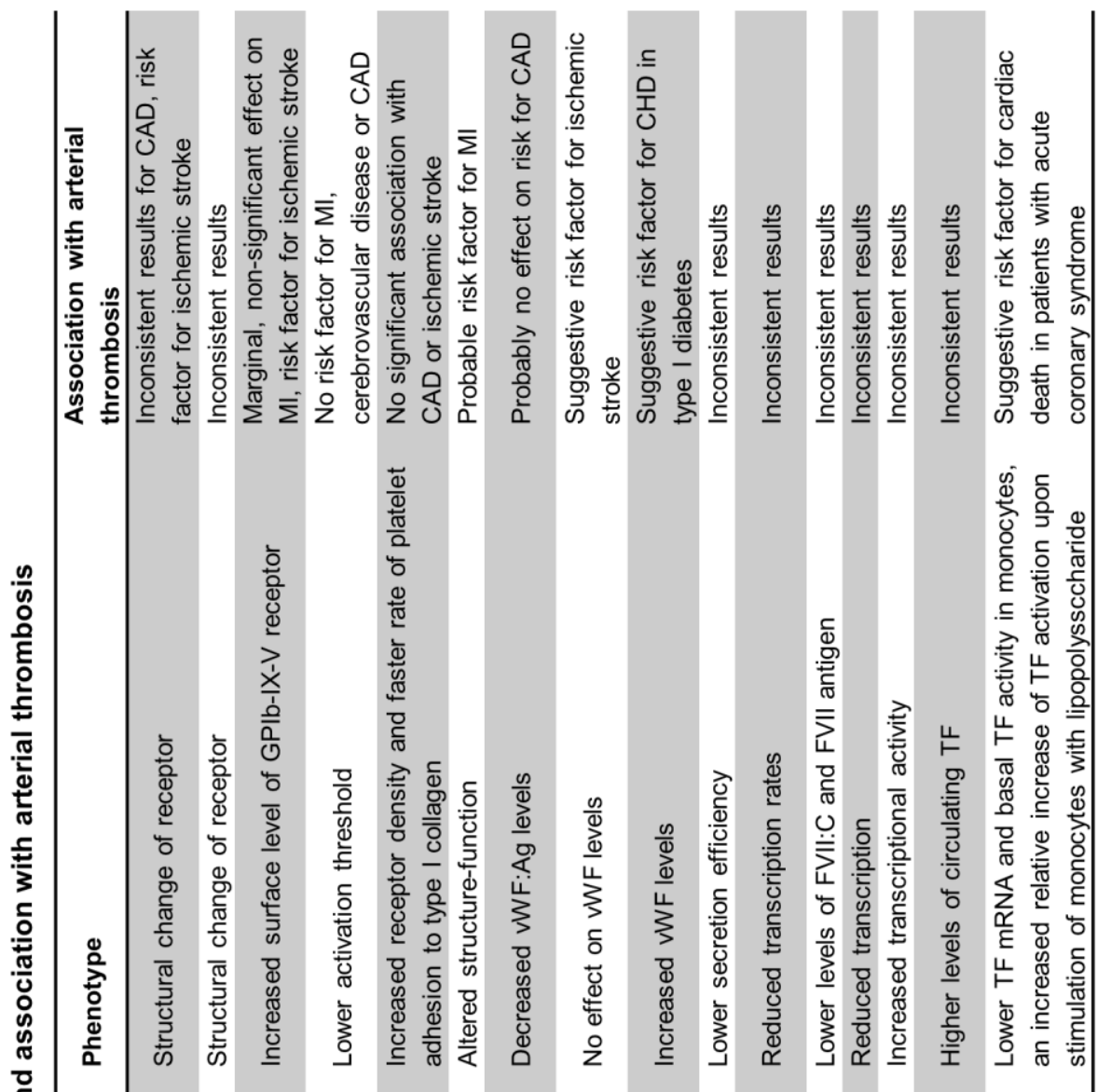

त

选

लें

\্ণ

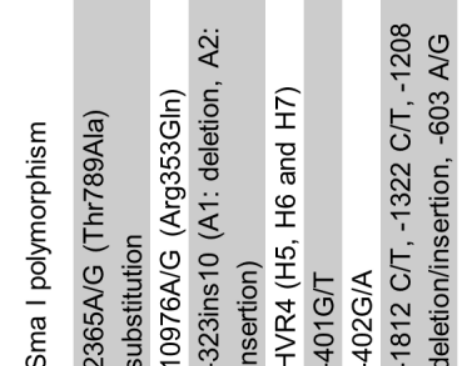

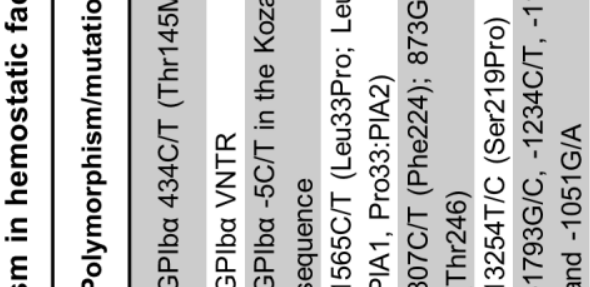

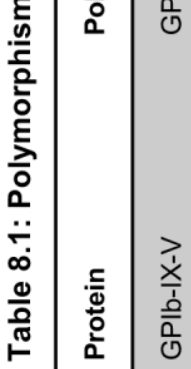
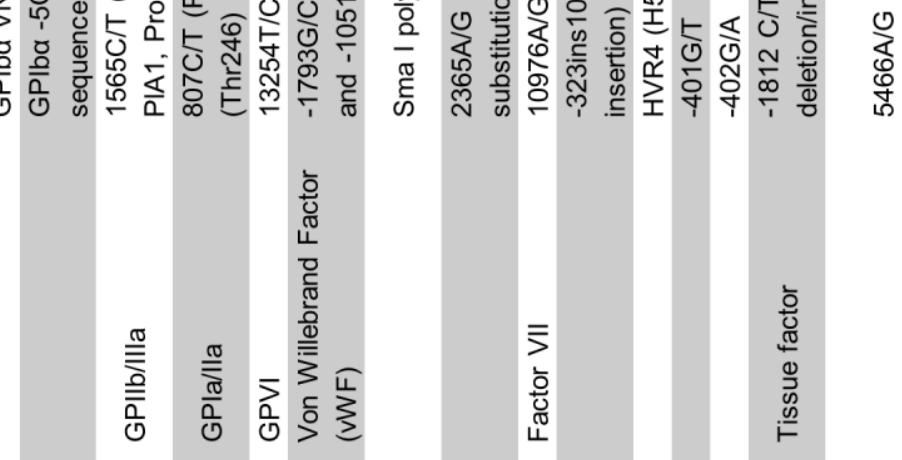
Genetics of arterial thrombosis

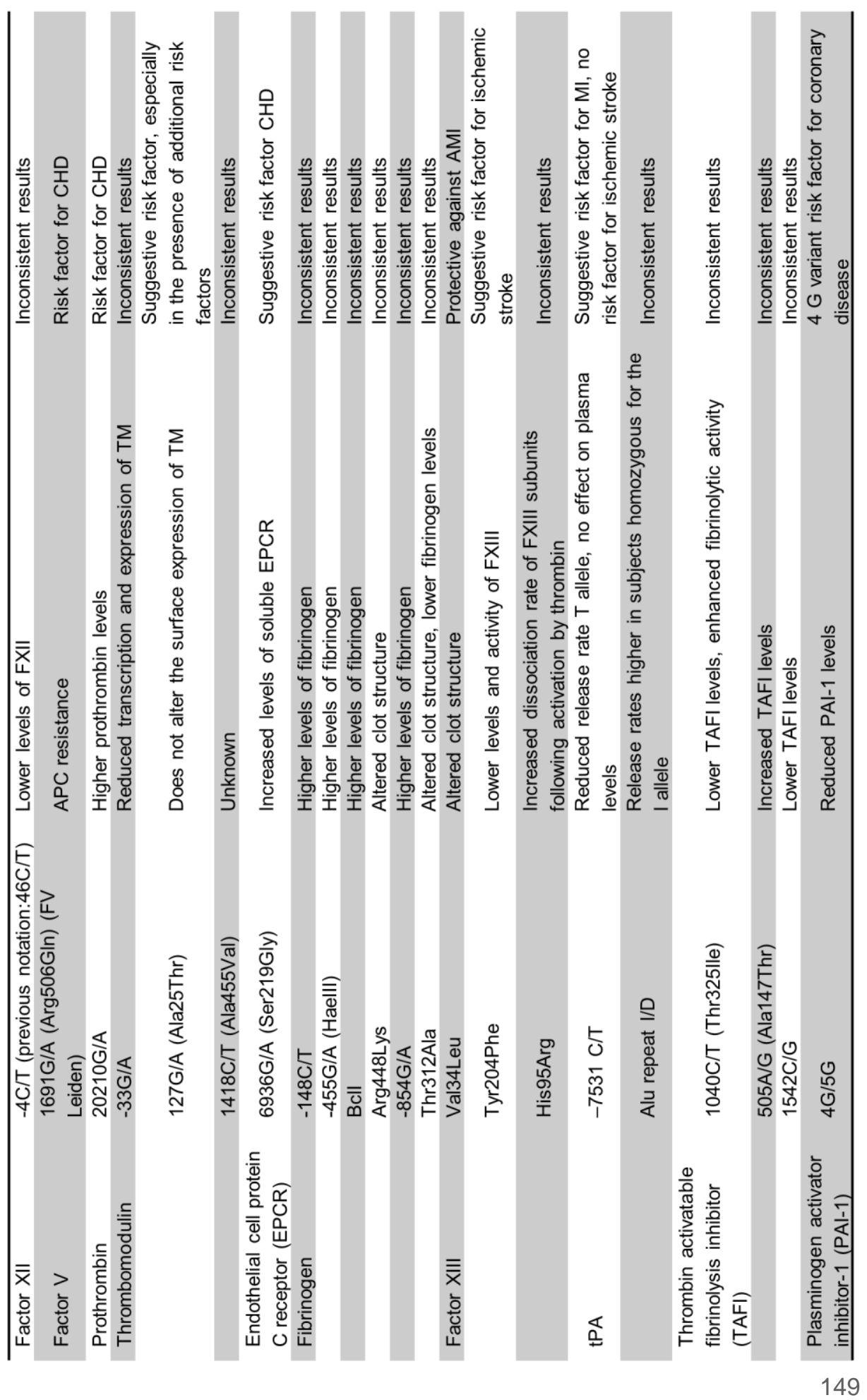




\section{Chapter 8}

\section{Conclusions}

There is no clear-cut association between polymorphisms in genes coding for hemostatic proteins and arterial thrombosis (see Table 8.1). Reported results are often contradictory due to heterogeneity of patient populations, deficiencies in study design and so on. Meta-analyses show only small or even no association of these polymorphisms and arterial thrombosis. This may seem remarkable, especially for those factors which are established risk markers of arterial thrombosis. Elevated levels of fibrinogen are consistently associated with arterial thrombosis, polymorphisms in these genes are at best contributing, by modifying fibrinogen structure or concentration. Platelet inhibitors are extensively used in the treatment of arterial thrombosis, however the studied polymorphisms were not related to CHD [1].

Clearly, arterial thrombosis is a multi-factorial disease and single polymorphisms likely contribute in a limited manner. From that perspective it is surprising that a common polymorphism such as FV Leiden is a contributing factor for CAD [1]. Such observations are important from a mechanistic perspective, showing that plasma proteins such as FV may play a role in (athero) thrombosis. The recent experimental data that link hypercoagulability to atherosclerosis could explain such a gene effect on the atherosclerosis phenotype. Clearly, more research is needed to further explore this exciting field.

\section{Clinical relevance}

From a clinical perspective, even more so than in venous thromboembolism, there is no indication for genotyping or thrombophilia screening in arterial thrombosis. Even though there is evidence from clinical studies that some SNP's do contribute to the development of arterial thrombosis, the contribution is only minor. Therefore, screening for these SNP's is not useful in most cases, particularly because the identification of risk alleles does not alter current management of the patient. Even in venous thromboembolic disease, thrombophilia is not recommended in current CBO guidelines. This may seem remarkable but is also based on the lack of management consequences. Nevertheless, from the perspective of the patient, their partner and family it may be unsatisfactory to refrain from any kind of additional thrombophilia testing, while techniques are available. The authors would indeed consider thrombophilia screening in individual cases, such as in young patients without any other obvious cardiovascular risk factors. One should however keep in mind 
that such analyses are primarily aimed at satisfying the doctor's or patient's curiosity and one should also consider the potential negative consequences of genotyping including effects on (life) insurance premiums.

\section{Acknowledgements}

The authors thank the Netherlands Heart Foundation for their financial support (NHF grant number 2008B120). 


\section{References}

1. Ye Z, Liu EH, Higgins JP, Keavney BD, Lowe GD, Collins R, Danesh J. Seven haemostatic gene polymorphisms in coronary disease: meta-analysis of 66,155 cases and 91,307 controls. Lancet. 2006; 367: 651-8.

2. Watson T, Shantsila E, Lip GY. Mechanisms of thrombogenesis in atrial fibrillation: Virchow's triad revisited. Lancet. 2009; 373: 155-66.

3. Seehaus S, Shahzad K, Kashif M, Vinnikov IA, Schiller M, Wang H, Madhusudhan T, Eckstein V, Bierhaus A, Bea F, Blessing E, Weiler H, Frommhold D, Nawroth PP, Isermann B. Hypercoagulability inhibits monocyte transendothelial migration through protease-activated receptor-1-, phospholipase-Cbeta-, phosphoinositide 3kinase-, and nitric oxide-dependent signaling in monocytes and promotes plaque stability. Circulation. 2009; 120: 774-84.

4. Borissoff Jl, Spronk HM, Heeneman S, ten Cate H. Is thrombin a key player in the 'coagulation-atherogenesis' maze? Cardiovasc Res. 2009; 82: 392-403.

5. Davi G, Patrono C. Platelet activation and atherothrombosis. N Engl J Med. 2007; 357: 2482-94.

6. Kiefer TL, Becker RC. Inhibitors of platelet adhesion. Circulation. 2009; 120: 248895.

7. Rivera J, Lozano ML, Navarro-Nunez L, Vicente V. Platelet receptors and signaling in the dynamics of thrombus formation. Haematologica. 2009; 94: 700-11.

8. Varga-Szabo D, Pleines I, Nieswandt B. Cell adhesion mechanisms in platelets. Arterioscler Thromb Vasc Biol. 2008; 28: 403-12.

9. Surin WR, Barthwal MK, Dikshit M. Platelet collagen receptors, signaling and antagonism: emerging approaches for the prevention of intravascular thrombosis. Thromb Res. 2008; 122: 786-803.

10. Bevers EM, Comfurius P, van Rijn JL, Hemker HC, Zwaal RF. Generation of prothrombin-converting activity and the exposure of phosphatidylserine at the outer surface of platelets. Eur J Biochem. 1982; 122: 429-36.

11. Macfarlane RG. An Enzyme Cascade in the Blood Clotting Mechanism, and Its Function as a Biochemical Amplifier. Nature. 1964; 202: 498-9.

12. Davie EW, Ratnoff OD. Waterfall Sequence for Intrinsic Blood Clotting. Science. 1964; 145: 1310-2.

13. Standeven KF, Ariens RA, Grant PJ. The molecular physiology and pathology of fibrin structure/function. Blood Rev. 2005; 19: 275-88.

14. Esmon CT. The protein C pathway. Chest. 2003; 124: 26S-32S.

15. Hackeng TM, Rosing J. Protein S as cofactor for TFPI. Arterioscler Thromb VasC Biol. 2009; 29: 2015-20.

16. Murata M, Matsubara Y, Kawano K, Zama T, Aoki N, Yoshino H, Watanabe G, Ishikawa K, Ikeda Y. Coronary artery disease and polymorphisms in a receptor mediating shear stress-dependent platelet activation. Circulation. 1997; 96: 3281-6.

17. Kuijpers RW, Faber NM, Cuypers HT, Ouwehand WH, von dem Borne AE. NH2terminal globular domain of human platelet glycoprotein $\mathrm{lb}$ alpha has a methionine 145/threonine145 amino acid polymorphism, which is associated with the HPA-2 (Ko) alloantigens. J Clin Invest. 1992; 89: 381-4.

18. Meyer M, Schellenberg I. Platelet membrane glycoprotein Ib: genetic polymorphism detected in the intact molecule and in proteolytic fragments. Thromb Res. 1990; 58: 233-42.

19. Lopez JA, Ludwig EH, McCarthy BJ. Polymorphism of human glycoprotein lb alpha results from a variable number of tandem repeats of a 13-amino acid sequence in the mucin-like macroglycopeptide region. Structure/function implications. J Biol Chem. 1992; 267: 10055-61. 
20. Afshar-Kharghan V, Li CQ, Khoshnevis-Asl M, Lopez JA. Kozak sequence polymorphism of the glycoprotein (GP) lbalpha gene is a major determinant of the plasma membrane levels of the platelet GP Ib-IX-V complex. Blood. 1999; 94: 18691.

21. Meisel C, Afshar-Kharghan V, Cascorbi I, Laule M, Stangl V, Felix SB, Baumann G, Lopez JA, Roots I, Stangl K. Role of Kozak sequence polymorphism of platelet glycoprotein Ibalpha as a risk factor for coronary artery disease and catheter interventions. J Am Coll Cardiol. 2001; 38: 1023-7.

22. Kenny D, Muckian C, Fitzgerald DJ, Cannon CP, Shields DC. Platelet glycoprotein $\mathrm{Ib}$ alpha receptor polymorphisms and recurrent ischaemic events in acute coronary syndrome patients. J Thromb Thrombolysis. 2002; 13: 13-9.

23. Frank MB, Reiner AP, Schwartz SM, Kumar PN, Pearce RM, Arbogast PG, Longstreth WT, Jr., Rosendaal FR, Psaty BM, Siscovick DS. The Kozak sequence polymorphism of platelet glycoprotein lbalpha and risk of nonfatal myocardial infarction and nonfatal stroke in young women. Blood. 2001; 97: 875-9.

24. Ishida F, Ito T, Takei M, Shimodaira S, Kitano K, Kiyosawa K. Genetic linkage of Kozak sequence polymorphism of the platelet glycoprotein Ib alpha with human platelet antigen-2 and variable number of tandem repeats polymorphism, and its relationship with coronary artery disease. Br J Haematol. 2000; 111: 1247-9.

25. Sucker C, Schmitz M, Hetzel GR, Grabensee B, Maruhn-Debowski B, Ostojic L, Scharf RE, Zotz RB. Are prothrombotic variants of platelet glycoprotein receptor polymorphisms involved in the pathogenesis of thrombotic microangiopathies? Clin Appl Thromb Hemost. 2009; 15: 402-7.

26. Croft SA, Hampton KK, Daly ME, Steeds RP, Channer KS, Samani NJ. Kozak sequence polymorphism in the platelet GPIbalpha gene is not associated with risk of myocardial infarction. Blood. 2000; 95: 2183-4.

27. Maguire JM, Thakkinstian A, Sturm J, Levi C, Lincz L, Parsons M, Whyte S, Attia J. Polymorphisms in platelet glycoprotein 1 balpha and factor VII and risk of ischemic stroke: a meta-analysis. Stroke. 2008; 39: 1710-6.

28. Gonzalez-Conejero R, Lozano ML, Rivera J, Corral J, Iniesta JA, Moraleda JM, Vicente V. Polymorphisms of platelet membrane glycoprotein $\mathrm{lb}$ associated with arterial thrombotic disease. Blood. 1998; 92: 2771-6.

29. Sonoda A, Murata M, Ito D, Tanahashi N, Ohta A, Tada Y, Takeshita E, Yoshida T, Saito I, Yamamoto M, Ikeda Y, Fukuuchi Y, Watanabe K. Association between platelet glycoprotein Ibalpha genotype and ischemic cerebrovascular disease. Stroke. 2000; 31: 493-7.

30. Ardissino D, Mannucci PM, Merlini PA, Duca F, Fetiveau R, Tagliabue L, Tubaro M, Galvani M, Ottani F, Ferrario M, Corral J, Margaglione M. Prothrombotic genetic risk factors in young survivors of myocardial infarction. Blood. 1999; 94: 46-51.

31. Carter AM, Catto AJ, Bamford JM, Grant PJ. Platelet GP IIla PIA and GP Ib variable number tandem repeat polymorphisms and markers of platelet activation in acute stroke. Arterioscler Thromb Vasc Biol. 1998; 18: 1124-31.

32. von dem Borne AE, Decary F. Nomenclature of platelet-specific antigens. Hum Immunol. 1990; 29: 1-2.

33. Michelson AD, Furman MI, Goldschmidt-Clermont P, Mascelli MA, Hendrix C, Coleman L, Hamlington J, Barnard MR, Kickler T, Christie DJ, Kundu S, Bray PF. Platelet GP IIIa $\mathrm{PI}(\mathrm{A})$ polymorphisms display different sensitivities to agonists. Circulation. 2000; 101: 1013-8.

34. Weiss EJ, Bray PF, Tayback M, Schulman SP, Kickler TS, Becker LC, Weiss JL, Gerstenblith G, Goldschmidt-Clermont PJ. A polymorphism of a platelet glycoprotein receptor as an inherited risk factor for coronary thrombosis. $N$ Engl J Med. 1996; 334: 1090-4. 
35. Mikkelsson J, Perola M, Laippala P, Savolainen V, Pajarinen J, Lalu K, Penttila A, Karhunen PJ. Glycoprotein IIla PI(A) polymorphism associates with progression of coronary artery disease and with myocardial infarction in an autopsy series of middle-aged men who died suddenly. Arterioscler Thromb Vasc Biol. 1999; 19: 2573-8.

36. Walter DH, Schachinger V, Elsner M, Dimmeler S, Zeiher AM. Platelet glycoprotein Illa polymorphisms and risk of coronary stent thrombosis. Lancet. 1997; 350: 12179.

37. Goldschmidt-Clermont PJ, Coleman LD, Pham YM, Cooke GE, Shear WS, Weiss EJ, Kral BG, Moy TF, Yook RM, Blumenthal RS, Becker DM, Becker LC, Bray PF. Higher prevalence of GPIIla PIA2 polymorphism in siblings of patients with premature coronary heart disease. Arch Pathol Lab Med. 1999; 123: 1223-9.

38. Motovska Z, Kvasnicka J, Widimsky P, Petr R, Hajkova J, Bobcikova P, Osmancik P, Odvodyova D, Katina S. Platelet glycoprotein GP VI 13254 C allele is an independent risk factor of premature myocardial infarction. Thromb Res. 2009.

39. Ridker PM, Hennekens CH, Schmitz C, Stampfer MJ, Lindpaintner K. PIA1/A2 polymorphism of platelet glycoprotein IIla and risks of myocardial infarction, stroke, and venous thrombosis. Lancet. 1997; 349: 385-8.

40. Marian AJ, Brugada R, Kleiman NS. Platelet glycoprotein IIla PIA polymorphism and myocardial infarction. $N$ Engl $J$ Med. 1996; 335: 1071-2; author reply 3-4.

41. Herrmann SM, Poirier O, Marques-Vidal P, Evans A, Arveiler D, Luc G, Emmerich $\mathrm{J}$, Cambien F. The Leu33/Pro polymorphism (PIA1/PIA2) of the glycoprotein Illa (GPIIla) receptor is not related to myocardial infarction in the ECTIM Study. Etude Cas-Temoins de l'Infarctus du Myocarde. Thromb Haemost. 1997; 77: 1179-81.

42. Carter AM, Ossei-Gerning N, Wilson IJ, Grant PJ. Association of the platelet $\mathrm{PI}(\mathrm{A})$ polymorphism of glycoprotein Ilb/llla and the fibrinogen Bbeta 448 polymorphism with myocardial infarction and extent of coronary artery disease. Circulation. 1997; 96: 1424-31.

43. Samani NJ, Lodwick D. Glycoprotein Illa polymorphism and risk of myocardial infarction. Cardiovasc Res. 1997; 33: 693-7.

44. Brenner B. Are platelet membrane glycoprotein polymorphisms predictive of arterial thrombosis? Isr Med Assoc J. 2002; 4: 458-9.

45. O'Donnell CJ, Larson MG, Feng D, Sutherland PA, Lindpaintner K, Myers RH, D'Agostino RA, Levy D, Tofler GH. Genetic and environmental contributions to platelet aggregation: the Framingham heart study. Circulation. 2001; 103: 3051-6.

46. Burr D, Doss H, Cooke GE, Goldschmidt-Clermont PJ. A meta-analysis of studies on the association of the platelet PIA polymorphism of glycoprotein IIla and risk of coronary heart disease. Stat Med. 2003; 22: 1741-60.

47. Kunicki TJ, Kritzik M, Annis DS, Nugent DJ. Hereditary variation in platelet integrin alpha 2 beta 1 density is associated with two silent polymorphisms in the alpha 2 gene coding sequence. Blood. 1997; 89: 1939-43.

48. Moshfegh K, Wuillemin WA, Redondo M, Lammle B, Beer JH, Liechti-Gallati S, Meyer BJ. Association of two silent polymorphisms of platelet glycoprotein la/lla receptor with risk of myocardial infarction: a case-control study. Lancet. 1999; 353: 351-4.

49. Santoso S, Kunicki TJ, Kroll H, Haberbosch W, Gardemann A. Association of the platelet glycoprotein la C807T gene polymorphism with nonfatal myocardial infarction in younger patients. Blood. 1999; 93: 2449-53.

50. Croft SA, Hampton KK, Sorrell JA, Steeds RP, Channer KS, Samani NJ, Daly ME. The GPla C807T dimorphism associated with platelet collagen receptor density is not a risk factor for myocardial infarction. Br J Haematol. 1999; 106: 771-6. 
51. Tsantes AE, Nikolopoulos GK, Bagos PG, Vaiopoulos G, Travlou A. Lack of association between the platelet glycoprotein la C807T gene polymorphism and coronary artery disease: a meta-analysis. Int J Cardiol. 2007; 118: 189-96.

52. Nikolopoulos GK, Tsantes AE, Bagos PG, Travlou A, Vaiopoulos G. Integrin, alpha 2 gene C807T polymorphism and risk of ischemic stroke: a meta-analysis. Thromb Res. 2007; 119: 501-10.

53. Croft SA, Samani NJ, Teare MD, Hampton KK, Steeds RP, Channer KS, Daly ME. Novel platelet membrane glycoprotein VI dimorphism is a risk factor for myocardial infarction. Circulation. 2001; 104: 1459-63.

54. Ollikainen E, Mikkelsson J, Perola M, Penttila A, Karhunen PJ. Platelet membrane collagen receptor glycoprotein $\mathrm{VI}$ polymorphism is associated with coronary thrombosis and fatal myocardial infarction in middle-aged men. Atherosclerosis. 2004; 176: 95-9.

55. Spiel AO, Gilbert JC, Jilma B. von Willebrand factor in cardiovascular disease: focus on acute coronary syndromes. Circulation. 2008; 117: 1449-59.

56. Fuster W, Bowie EJ, Lewis JC, Fass DN, Owen CA, Jr., Brown AL. Resistance to arteriosclerosis in pigs with von Willebrand's disease. Spontaneous and high cholesterol diet-induced arteriosclerosis. J Clin Invest. 1978; 61: 722-30.

57. Nichols TC, Bellinger DA, Tate DA, Reddick RL, Read MS, Koch GG, Brinkhous $\mathrm{KM}$, Griggs TR. von Willebrand factor and occlusive arterial thrombosis. A study in normal and von Willebrand's disease pigs with diet-induced hypercholesterolemia and atherosclerosis. Arteriosclerosis. 1990; 10: 449-61.

58. Methia N, Andre P, Denis CV, Economopoulos M, Wagner DD. Localized reduction of atherosclerosis in von Willebrand factor-deficient mice. Blood. 2001; 98: 1424-8.

59. Griggs TR, Reddick RL, Sultzer D, Brinkhous KM. Susceptibility to atherosclerosis in aortas and coronary arteries of swine with von Willebrand's disease. $A m ~ J$ Pathol. 1981; 102: 137-45.

60. Bilora F, Dei Rossi C, Girolami B, Casonato A, Zanon E, Bertomoro A, Girolami A. Do hemophilia $A$ and von Willebrand disease protect against carotid atherosclerosis? A comparative study between coagulopathics and normal subjects by means of carotid echo-color Doppler scan. Clin Appl Thromb Hemost. 1999; 5: 232-5.

61. Bilora F, Boccioletti V, Zanon E, Petrobelli F, Girolami A. Hemophilia A, von Willebrand disease, and atherosclerosis of abdominal aorta and leg arteries: factor VIII and von Willebrand factor defects appear to protect abdominal aorta and leg arteries from atherosclerosis. Clin Appl Thromb Hemost. 2001; 7: 311-3.

62. Sramek A, Reiber JH, Gerrits WB, Rosendaal FR. Decreased coagulability has no clinically relevant effect on atherogenesis: observations in individuals with a hereditary bleeding tendency. Circulation. 2001; 104: 762-7.

63. Sramek A, Bucciarelli P, Federici AB, Mannucci PM, De Rosa V, Castaman G, Morfini M, Mazzucconi MG, Rocino A, Schiavoni M, Scaraggi FA, Reiber JH, Rosendaal FR. Patients with type 3 severe von Willebrand disease are not protected against atherosclerosis: results from a multicenter study in 47 patients. Circulation. 2004; 109: 740-4.

64. Leebeek FW, van der Meer IM, Witteman JC. Genetic variability of von Willebrand factor and atherosclerosis. Circulation. 2004; 110: e57.

65. Bilora F, Zanon E, Casonato A, Bertomoro A, Petrobelli F, Cavraro M, Campagnolo E, Girolami A. Type Ilb von Willebrand disease: role of qualitative defects in atherosclerosis and endothelial dysfunction. Clin Appl Thromb Hemost. 2007; 13: 384-90.

66. Keightley AM, Lam YM, Brady JN, Cameron CL, Lillicrap D. Variation at the von Willebrand factor (VWF) gene locus is associated with plasma vWF:Ag levels: 
identification of three novel single nucleotide polymorphisms in the vWF gene promoter. Blood. 1999; 93: 4277-83.

67. Harvey PJ, Keightley AM, Lam YM, Cameron C, Lillicrap D. A single nucleotide polymorphism at nucleotide -1793 in the von Willebrand factor (VWF) regulatory region is associated with plasma VWF:Ag levels. Br J Haematol. 2000; 109: 34953.

68. Dai K, Gao W, Ruan C. The Sma I polymorphism in the von Willebrand factor gene associated with acute ischemic stroke. Thromb Res. 2001; 104: 389-95.

69. Lacquemant C, Gaucher C, Delorme C, Chatellier G, Gallois Y, Rodier M, Passa P, Balkau B, Mazurier C, Marre M, Froguel P. Association between high von willebrand factor levels and the Thr789Ala vWF gene polymorphism but not with nephropathy in type I diabetes. The GENEDIAB Study Group and the DESIR Study Group. Kidney Int. 2000; 57: 1437-43.

70. Klemm T, Mehnert AK, Siegemund A, Wiesner TD, Gelbrich G, Bluher M, Paschke R. Impact of the Thr789Ala variant of the von Willebrand factor levels, on ristocetin co-factor and collagen binding capacity and its association with coronary heart disease in patients with diabetes mellitus type 2. Exp Clin Endocrinol Diabetes. 2005; 113: 568-72.

71. van der Meer IM, Brouwers GJ, Bulk S, Leebeek FW, van der Kuip DA, Hofman A, Witteman JC, Gomez Garcia EB. Genetic variability of von Willebrand factor and risk of coronary heart disease: the Rotterdam Study. Br J Haematol. 2004; 124: 343-7.

72. Di Bitondo R, Cameron CL, Daly ME, Croft SA, Steeds RP, Channer KS, Samani NJ, Lillicrap D, Winship PR. The -1185 A/G and $-1051 \mathrm{G} / \mathrm{A}$ dimorphisms in the von Willebrand factor gene promoter and risk of myocardial infarction. Br J Haematol. 2001; 115: 701-6.

73. Simon D, Paludo CA, Ghisleni GC, Manfroi WC, Roisenberg I. Association studies between $-1185 \mathrm{~A} / \mathrm{G}$ von Willebrand factor gene polymorphism and coronary artery disease. Braz J Med Biol Res. 2003; 36: 709-14.

74. Wu O, Bayoumi N, Vickers MA, Clark P. $\mathrm{ABO}(\mathrm{H})$ blood groups and vascular disease: a systematic review and meta-analysis. J Thromb Haemost. 2008; 6: 62-9.

75. Meade TW, Mellows S, Brozovic M, Miller GJ, Chakrabarti RR, North WR, Haines AP, Stirling Y, Imeson JD, Thompson SG. Haemostatic function and ischaemic heart disease: principal results of the Northwick Park Heart Study. Lancet. 1986; 2: 533-7.

76. Hoffman CJ, Miller RH, Lawson WE, Hultin MB. Elevation of factor VII activity and mass in young adults at risk of ischemic heart disease. J Am Coll Cardiol. 1989; 14: 941-6.

77. Smith FB, Lee AJ, Fowkes FG, Price JF, Rumley A, Lowe GD. Hemostatic factors as predictors of ischemic heart disease and stroke in the Edinburgh Artery Study. Arterioscler Thromb Vasc Biol. 1997; 17: 3321-5.

78. Lane A, Green F, Scarabin PY, Nicaud V, Bara L, Humphries S, Evans A, Luc G, Cambou JP, Arveiler D, Cambien F. Factor VII Arg/Gln353 polymorphism determines factor VII coagulant activity in patients with myocardial infarction (MI) and control subjects in Belfast and in France but is not a strong indicator of MI risk in the ECTIM study. Atherosclerosis. 1996; 119: 119-27.

79. Humphries SE, Lane A, Green FR, Cooper J, Miller GJ. Factor VII coagulant activity and antigen levels in healthy men are determined by interaction between factor VII genotype and plasma triglyceride concentration. Arterioscler Thromb. 1994; 14: 193-8.

80. Miller GJ, Stirling Y, Esnouf MP, Heinrich J, van de Loo J, Kienast J, Wu KK, Morrissey JH, Meade TW, Martin JC, et al. Factor VII-deficient substrate plasmas 
depleted of protein $\mathrm{C}$ raise the sensitivity of the factor VII bio-assay to activated factor VII: an international study. Thromb Haemost. 1994; 71: 38-48.

81. Lowe GD, Rumley A, McMahon AD, Ford I, O'Reilly DS, Packard CJ. Interleukin-6, fibrin D-dimer, and coagulation factors VII and XIla in prediction of coronary heart disease. Arterioscler Thromb Vasc Biol. 2004; 24: 1529-34.

82. Green F, Kelleher C, Wilkes H, Temple A, Meade T, Humphries S. A common genetic polymorphism associated with lower coagulation factor VII levels in healthy individuals. Arterioscler Thromb. 1991; 11: 540-6.

83. Marchetti G, Patracchini P, Papacchini M, Ferrati M, Bernardi F. A polymorphism in the $5^{\prime}$ region of coagulation factor VII gene (F7) caused by an inserted decanucleotide. Hum Genet. 1993; 90: 575-6.

84. Bernardi F, Marchetti G, Pinotti M, Arcieri P, Baroncini C, Papacchini M, Zepponi E, Ursicino N, Chiarotti F, Mariani G. Factor VII gene polymorphisms contribute about one third of the factor VII level variation in plasma. Arterioscler Thromb Vasc Biol. 1996; 16: 72-6.

85. Sacchi E, Tagliabue L, Scoglio R, Baroncini C, Coppola R, Bernardi F, Mannucci PM. Plasma factor VII levels are influenced by a polymorphism in the promoter region of the FVII gene. Blood Coagul Fibrinolysis. 1996; 7: 114-7.

86. Pollak ES, Hung HL, Godin W, Overton GC, High KA. Functional characterization of the human factor VII 5'-flanking region. J Biol Chem. 1996; 271: 1738-47.

87. van 't Hooft FM, Silveira A, Tornvall P, Iliadou A, Ehrenborg E, Eriksson P, Hamsten A. Two common functional polymorphisms in the promoter region of the coagulation factor VII gene determining plasma factor VII activity and mass concentration. Blood. 1999; 93: 3432-41.

88. Di Castelnuovo A, D'Orazio A, Amore C, Falanga A, Donati MB, lacoviello L. The decanucleotide insertion/deletion polymorphism in the promoter region of the coagulation factor VII gene and the risk of familial myocardial infarction. Thromb Res. 2000; 98: 9-17.

89. Endler G, Mannhalter C. Polymorphisms in coagulation factor genes and their impact on arterial and venous thrombosis. Clin Chim Acta. 2003; 330: 31-55.

90. Lane DA, Grant PJ. Role of hemostatic gene polymorphisms in venous and arterial thrombotic disease. Blood. 2000; 95: 1517-32.

91. Lane A, Cruickshank JK, Mitchell J, Henderson A, Humphries S, Green F. Genetic and environmental determinants of factor VII coagulant activity in ethnic groups at differing risk of coronary heart disease. Atherosclerosis. 1992; 94: 43-50.

92. Quek SC, Low PS, Saha N, Heng CK. The effects of three factor VII polymorphisms on factor VII coagulant levels in healthy Singaporean Chinese, Malay and Indian newborns. Ann Hum Genet. 2006; 70: 951-7.

93. Hunault M, Arbini AA, Lopaciuk S, Carew JA, Bauer KA. The Arg353GIn polymorphism reduces the level of coagulation factor VII. In vivo and in vitro studies. Arterioscler Thromb Vasc Biol. 1997; 17: 2825-9.

94. Iacoviello L, Di Castelnuovo A, De Knijff P, D'Orazio A, Amore C, Arboretti R, Kluft $\mathrm{C}$, Benedetta Donati M. Polymorphisms in the coagulation factor VII gene and the risk of myocardial infarction. N Engl J Med. 1998; 338: 79-85.

95. Girelli D, Russo C, Ferraresi P, Olivieri O, Pinotti M, Friso S, Manzato F, Mazzucco A, Bernardi F, Corrocher R. Polymorphisms in the factor VII gene and the risk of myocardial infarction in patients with coronary artery disease. $N$ Engl $J$ Med. 2000; 343: 774-80.

96. Bozzini C, Girelli D, Bernardi F, Ferraresi P, Olivieri O, Pinotti M, Martinelli N, Manzato F, Friso S, Villa G, Pizzolo F, Beltrame F, Corrocher R. Influence of polymorphisms in the factor VII gene promoter on activated factor VII levels and on the risk of myocardial infarction in advanced coronary atherosclerosis. Thromb Haemost. 2004; 92: 541-9. 
97. Mrozikiewicz PM, Cascorbi I, Ziemer S, Laule M, Meisel C, Stangl V, Rutsch W, Wernecke K, Baumann G, Roots I, Stangl K. Reduced procedural risk for coronary catheter interventions in carriers of the coagulation factor VII-Gln353 gene. J Am Coll Cardiol. 2000; 36: 1520-5.

98. Doggen CJ, Manger Cats V, Bertina RM, Reitsma PH, Vandenbroucke JP, Rosendaal FR. A genetic propensity to high factor VII is not associated with the risk of myocardial infarction in men. Thromb Haemost. 1998; 80: 281-5.

99. Arnaud E, Barbalat V, Nicaud V, Cambien F, Evans A, Morrison C, Arveiler D, Luc G, Ruidavets JB, Emmerich J, Fiessinger JN, Aiach M. Polymorphisms in the $5^{\prime}$ regulatory region of the tissue factor gene and the risk of myocardial infarction and venous thromboembolism: the ECTIM and PATHROS studies. Etude Cas-Temoins de I'Infarctus du Myocarde. Paris Thrombosis case-control Study. Arterioscler Thromb Vasc Biol. 2000; 20: 892-8.

100. Malarstig A, Tenno T, Johnston N, Lagerqvist B, Axelsson T, Syvanen AC, Wallentin L, Siegbahn A. Genetic variations in the tissue factor gene are associated with clinical outcome in acute coronary syndrome and expression levels in human monocytes. Arterioscler Thromb Vasc Biol. 2005; 25: 2667-72.

101. Ott I, Koch W, von Beckerath N, de Waha R, Malawaniec A, Mehilli J, Schomig A, Kastrati A. Tissue factor promotor polymorphism -603 A/G is associated with myocardial infarction. Atherosclerosis. 2004; 177: 189-91.

102. Campo G, Valgimigli M, Ferraresi $P$, Malagutti $P$, Baroni M, Arcozzi C, Gemmati D, Percoco G, Parrinello G, Ferrari R, Bernardi F. Tissue factor and coagulation factor VII levels during acute myocardial infarction: association with genotype and adverse events. Arterioscler Thromb Vasc Biol. 2006; 26: 2800-6.

103. Renne T, Pozgajova M, Gruner S, Schuh K, Pauer HU, Burfeind P, Gailani D, Nieswandt B. Defective thrombus formation in mice lacking coagulation factor XII. $J$ Exp Med. 2005; 202: 271-81.

104. van der Meijden PE, Munnix IC, Auger JM, Govers-Riemslag JW, Cosemans JM, Kuijpers MJ, Spronk HM, Watson SP, Renne T, Heemskerk JW. Dual role of collagen in factor XII-dependent thrombus formation. Blood. 2009; 114: 881-90.

105. Smith SA, Mutch NJ, Baskar D, Rohloff P, Docampo R, Morrissey JH. Polyphosphate modulates blood coagulation and fibrinolysis. Proceedings of the National Academy of Sciences of the United States of America. 2006; 103: 903-8.

106. Merlo C, Wuillemin WA, Redondo M, Furlan M, Sulzer I, Kremer-Hovinga J, Binder BR, Lammle B. Elevated levels of plasma prekallikrein, high molecular weight kininogen and factor XI in coronary heart disease. Atherosclerosis. 2002; 161: 2617.

107. Vaziri ND, Kennedy SC, Kennedy D, Gonzales E. Coagulation, fibrinolytic, and inhibitory proteins in acute myocardial infarction and angina pectoris. Am J Med. 1992; 93: 651-7.

108. Cooper JA, Miller GJ, Bauer KA, Morrissey JH, Meade TW, Howarth DJ, Barzegar $\mathrm{S}$, Mitchell JP, Rosenberg RD. Comparison of novel hemostatic factors and conventional risk factors for prediction of coronary heart disease. Circulation. 2000; 102: 2816-22.

109. Govers-Riemslag JW, Smid M, Cooper JA, Bauer KA, Rosenberg RD, Hack CE, Hamulyak K, Spronk HM, Miller GJ, ten Cate H. The plasma kallikrein-kinin system and risk of cardiovascular disease in men. J Thromb Haemost. 2007; 5: 1896-903.

110. Grundt H, Nilsen DW, Hetland O, Valente E, Fagertun HE. Activated factor 12 (FXIla) predicts recurrent coronary events after an acute myocardial infarction. Am Heart J. 2004; 147: 260-6.

111. Colhoun HM, Zito F, Norman Chan N, Rubens MB, Fuller JH, Humphries SE. Activated factor XII levels and factor XII 46C>T genotype in relation to coronary 
artery calcification in patients with type 1 diabetes and healthy subjects. Atherosclerosis. 2002; 163: 363-9.

112. Doggen CJ, Rosendaal FR, Meijers JC. Levels of intrinsic coagulation factors and the risk of myocardial infarction among men: Opposite and synergistic effects of factors XI and XII. Blood. 2006; 108: 4045-51.

113. Girolami A, Morello M, Girolami B, Lombardi AM, Bertolo C. Myocardial infarction and arterial thrombosis in severe (homozygous) FXII deficiency: no apparent causative relation. Clin Appl Thromb Hemost. 2005; 11: 49-53.

114. Kanaji T, Okamura T, Osaki K, Kuroiwa M, Shimoda K, Hamasaki N, Niho Y. A common genetic polymorphism (46 C to T substitution) in the 5 '-untranslated region of the coagulation factor XII gene is associated with low translation efficiency and decrease in plasma factor XII level. Blood. 1998; 91: 2010-4.

115. Zito F, Lowe GD, Rumley A, McMahon AD, Humphries SE. Association of the factor XII 46C>T polymorphism with risk of coronary heart disease (CHD) in the WOSCOPS study. Atherosclerosis. 2002; 165: 153-8.

116. Santamaria A, Martinez-Rubio A, Mateo J, Tirado I, Soria JM, Fontcuberta J. Homozygosity of the T allele of the $46 \mathrm{C}-->\mathrm{T}$ polymorphism in the $\mathrm{F} 12$ gene is a risk factor for acute coronary artery disease in the Spanish population. Haematologica. 2004; 89: 878-9.

117. Santamaria A, Mateo J, Tirado I, Oliver A, Belvis R, Marti-Fabregas J, Felices R, Soria JM, Souto JC, Fontcuberta J. Homozygosity of the T allele of the $46 \mathrm{C}->\mathrm{T}$ polymorphism in the F12 gene is a risk factor for ischemic stroke in the Spanish population. Stroke. 2004; 35: 1795-9.

118. Endler G, Mannhalter C, Sunder-Plassmann H, Lalouschek W, Kapiotis S, Exner M, Jordanova N, Meier S, Kunze F, Wagner O, Huber K. Homozygosity for the C-$>$ T polymorphism at nucleotide 46 in the 5 ' untranslated region of the factor XII gene protects from development of acute coronary syndrome. Br J Haematol. 2001; 115: 1007-9.

119. Kohler HP, Futers TS, Grant PJ. FXII (46C-->T) polymorphism and in vivo generation of FXII activity--gene frequencies and relationship in patients with coronary artery disease. Thromb Haemost. 1999; 81: 745-7.

120. Bach J, Endler G, Winkelmann BR, Boehm BO, Maerz W, Mannhalter C, Hellstern P. Coagulation factor XII (FXII) activity, activated FXII, distribution of FXII C46T gene polymorphism and coronary risk. J Thromb Haemost. 2008; 6: 291-6.

121. Athanasiadis G, Esteban E, Vidal MG, Torres RC, Bahri R, Moral P. Polymorphism FXII 46C $>T$ and cardiovascular risk: additional data from Spanish and Tunisian patients. BMC Res Notes. 2009; 2: 154.

122. Oguchi S, Ito D, Murata M, Yoshida T, Tanahashi N, Fukuuchi Y, Ikeda $Y$, Watanabe K. Genotype distribution of the $46 \mathrm{C} / \mathrm{T}$ polymorphism of coagulation factor XII in the Japanese population: absence of its association with ischemic cerebrovascular disease. Thromb Haemost. 2000; 83: 178-9.

123. Yazdani-Biuki B, Krippl P, Brickmann K, Fuerst F, Langsenlehner U, Paulweber B, Pilger E, Wascher T, Brezinschek HP, Renner W. The Functional Promoter Polymorphism of the Coagulation Factor XII Gene is not Associated With Peripheral Arterial Disease. Angiology. 2009.

124. Roldan V, Corral J, Marin F, Pineda J, Vicente V, Gonzalez-Conejero R. Synergistic association between hypercholesterolemia and the C46T factor XII polymorphism for developing premature myocardial infarction. Thromb Haemost. 2005; 94: 1294-9.

125. Salomon O, Steinberg DM, Koren-Morag N, Tanne D, Seligsohn U. Reduced incidence of ischemic stroke in patients with severe factor XI deficiency. Blood. 2008; 111: 4113-7. 
126. Salomon O, Steinberg DM, Dardik R, Rosenberg N, Zivelin A, Tamarin I, Ravid B, Berliner S, Seligsohn U. Inherited factor XI deficiency confers no protection against acute myocardial infarction. J Thromb Haemost. 2003; 1: 658-61.

127. Rosendaal FR, Varekamp I, Smit C, Brocker-Vriends AH, van Dijck $H$, Vandenbroucke JP, Hermans J, Suurmeijer TP, Briet E. Mortality and causes of death in Dutch haemophiliacs, 1973-86. Br J Haematol. 1989; 71: 71-6.

128. Aronson DL. Cause of death in hemophilia A patients in the United States from 1968 to 1979. Am J Hematol. 1988; 27: 7-12.

129. Sramek A, Kriek M, Rosendaal FR. Decreased mortality of ischaemic heart disease among carriers of haemophilia. Lancet. 2003; 362: 351-4.

130. Darby SC, Kan SW, Spooner RJ, Giangrande PL, Hill FG, Hay CR, Lee CA, Ludlam CA, Williams M. Mortality rates, life expectancy, and causes of death in people with hemophilia A or B in the United Kingdom who were not infected with HIV. Blood. 2007; 110: 815-25.

131. Pruissen DM, Kappelle LJ, Rosendaal FR, Algra A. Prothrombotic gene variation in patients with large and small vessel disease. Neuroepidemiology. 2008; 31: 89-92.

132. Martini $\mathrm{CH}$, Doggen CJ, Cavallini C, Rosendaal FR, Mannucci PM. No effect of polymorphisms in prothrombotic genes on the risk of myocardial infarction in young adults without cardiovascular risk factors. J Thromb Haemost. 2005; 3: 177-9.

133. Eitzman DT, Westrick RJ, Shen Y, Bodary PF, Gu S, Manning SL, Dobies SL, Ginsburg D. Homozygosity for factor V Leiden leads to enhanced thrombosis and atherosclerosis in mice. Circulation. 2005; 111: 1822-5.

134. Kerlin BA, Yan SB, Isermann BH, Brandt JT, Sood R, Basson BR, Joyce DE, Weiler $\mathrm{H}$, Dhainaut JF. Survival advantage associated with heterozygous factor $\mathrm{V}$ Leiden mutation in patients with severe sepsis and in mouse endotoxemia. Blood. 2003; 102: 3085-92.

135. Volzke H, Wolff B, Grimm R, Robinson DM, Schuster G, Herrmann FH, Motz W, Rettig R. Interaction between factor $V$ Leiden and serum LDL cholesterol increases the risk of atherosclerosis. Atherosclerosis. 2005; 180: 341-7.

136. Pruissen DM, Kappelle LJ, Rosendaal FR, Algra A. Prothrombotic genetic variants and atherosclerosis in patients with cerebral ischemia of arterial origin. Atherosclerosis. 2009; 204: 191-5.

137. Marcucci R, Sofi F, Fedi S, Lari B, Sestini I, Cellai AP, Pulli R, Pratesi G, Pratesi C, Gensini GF, Abbate R. Thrombophilic risk factors in patients with severe carotid atherosclerosis. J Thromb Haemost. 2005; 3: 502-7.

138. Inbal A, Freimark D, Modan B, Chetrit A, Matetzky S, Rosenberg N, Dardik R, Baron Z, Seligsohn U. Synergistic effects of prothrombotic polymorphisms and atherogenic factors on the risk of myocardial infarction in young males. Blood. 1999; 93: 2186-90.

139. Doggen CJ, Cats VM, Bertina RM, Rosendaal FR. Interaction of coagulation defects and cardiovascular risk factors: increased risk of myocardial infarction associated with factor V Leiden or prothrombin 20210A. Circulation. 1998; 97: 1037-41.

140. Redondo M, Watzke HH, Stucki B, Sulzer I, Biasiutti FD, Binder BR, Furlan M, Lammle B, Wuillemin WA. Coagulation factors II, V, VII, and X, prothrombin gene 20210G-->A transition, and factor V Leiden in coronary artery disease: high factor $\mathrm{V}$ clotting activity is an independent risk factor for myocardial infarction. Arterioscler Thromb Vasc Biol. 1999; 19: 1020-5.

141. Ameziane N, Lebret D, Combe A, Aumont MC, de Prost D. No association between the R2 factor $V$ gene and acute coronary events. Thromb Haemost. 2001; 85: 5667.

142. Mahmoodi BK, Brouwer JL, Veeger NJ, van der Meer J. Hereditary deficiency of protein $\mathrm{C}$ or protein $\mathrm{S}$ confers increased risk of arterial thromboembolic events at a 
young age: results from a large family cohort study. Circulation. 2008; 118: 165967.

143. Salomaa V, Matei C, Aleksic N, Sansores-Garcia L, Folsom AR, Juneja H, Chambless LE, Wu KK. Soluble thrombomodulin as a predictor of incident coronary heart disease and symptomless carotid artery atherosclerosis in the Atherosclerosis Risk in Communities (ARIC) Study: a case-cohort study. Lancet. 1999; 353: 1729-34.

144. Wu KK. Soluble thrombomodulin and coronary heart disease. Curr Opin Lipidol. 2003; 14: 373-5.

145. Weiler H, Isermann BH. Thrombomodulin. J Thromb Haemost. 2003; 1: 1515-24.

146. Ireland H, Kunz G, Kyriakoulis K, Stubbs PJ, Lane DA. Thrombomodulin gene mutations associated with myocardial infarction. Circulation. 1997; 96: 15-8.

147. Li YH, Chen JH, Wu HL, Shi GY, Huang HC, Chao TH, Tsai WC, Tsai LM, Guo HR, Wu WS, Chen ZC. G-33A mutation in the promoter region of thrombomodulin gene and its association with coronary artery disease and plasma soluble thrombomodulin levels. Am J Cardiol. 2000; 85: 8-12.

148. Li YH, Chen CH, Yeh PS, Lin HJ, Chang BI, Lin JC, Guo HR, Wu HL, Shi GY, Lai $\mathrm{ML}$, Chen $\mathrm{JH}$. Functional mutation in the promoter region of thrombomodulin gene in relation to carotid atherosclerosis. Atherosclerosis. 2001; 154: 713-9.

149. Park HY, Nabika T, Jang Y, Kwon HM, Cho SY, Masuda J. Association of G-33A polymorphism in the thrombomodulin gene with myocardial infarction in Koreans. Hypertens Res. 2002; 25: 389-94.

150. Zhao J, Zhou X, Huang J, Chen J, Gu D. Association study of the thrombomodulin $33 \mathrm{G}>\mathrm{A}$ polymorphism with coronary artery disease and myocardial infarction in Chinese Han population. Int J Cardiol. 2005; 100: 383-8.

151. Doggen CJ, Kunz G, Rosendaal FR, Lane DA, Vos HL, Stubbs PJ, Manger Cats V, Ireland $\mathrm{H}$. A mutation in the thrombomodulin gene, 127G to A coding for Ala25Thr, and the risk of myocardial infarction in men. Thromb Haemost. 1998; 80: 743-8.

152. Norlund L, Holm J, Zoller B, Ohlin AK. A common thrombomodulin amino acid dimorphism is associated with myocardial infarction. Thromb Haemost. 1997; 77: 248-51.

153. Cole JW, Roberts SC, Gallagher M, Giles WH, Mitchell BD, Steinberg KK, Wozniak MA, Macko RF, Reinhart LJ, Kittner SJ. Thrombomodulin Ala455Val Polymorphism and the risk of cerebral infarction in a biracial population: the Stroke Prevention in Young Women Study. BMC Neurol. 2004; 4: 21.

154. Wu KK, Aleksic N, Ahn C, Boerwinkle E, Folsom AR, Juneja H. Thrombomodulin Ala455Val polymorphism and risk of coronary heart disease. Circulation. 2001; 103: 1386-9.

155. Faioni EM, Franchi F, Castaman G, Biguzzi E, Rodeghiero F. Mutations in the thrombomodulin gene are rare in patients with severe thrombophilia. $\mathrm{Br} J$ Haematol. 2002; 118: 595-9.

156. van der Velden PA, Krommenhoek-Van Es T, Allaart CF, Bertina RM, Reitsma PH. A frequent thrombomodulin amino acid dimorphism is not associated with thrombophilia. Thromb Haemost. 1991; 65: 511-3.

157. Delvaeye M, Noris M, De Vriese A, Esmon CT, Esmon NL, Ferrell G, Del-Favero J, Plaisance S, Claes B, Lambrechts D, Zoja C, Remuzzi G, Conway EM. Thrombomodulin mutations in atypical hemolytic-uremic syndrome. $N$ Engl J Med. 2009; 361: 345-57.

158. Ireland H, Konstantoulas CJ, Cooper JA, Hawe E, Humphries SE, Mather $H$, Goodall $A H$, Hogwood J, Juhan-Vague I, Yudkin JS, di Minno G, Margaglione M, Hamsten A, Miller GJ, Bauer KA, Kim YT, Stearns-Kurosawa DJ, Kurosawa S. EPCR Ser219Gly: elevated SEPCR, prothrombin F1+2, risk for coronary heart 
disease, and increased sEPCR shedding in vitro. Atherosclerosis. 2005; 183: 28392.

159. Kelleher CC. Plasma fibrinogen and factor VII as risk factors for cardiovascular disease. Eur J Epidemiol. 1992; 8 Suppl 1: 79-82.

160. Scarabin PY, Aillaud MF, Amouyel P, Evans A, Luc G, Ferrieres J, Arveiler D, Juhan-Vague I. Associations of fibrinogen, factor VII and PAI-1 with baseline findings among 10,500 male participants in a prospective study of myocardial infarction--the PRIME Study. Prospective Epidemiological Study of Myocardial Infarction. Thromb Haemost. 1998; 80: 749-56.

161. Danesh J, Lewington S, Thompson SG, Lowe GD, Collins R, Kostis JB, Wilson AC, Folsom AR, Wu K, Benderly M, Goldbourt U, Willeit J, Kiechl S, Yarnell JW, Sweetnam PM, Elwood PC, Cushman M, Psaty BM, Tracy RP, Tybjaerg-Hansen A, et al. Plasma fibrinogen level and the risk of major cardiovascular diseases and nonvascular mortality: an individual participant meta-analysis. Jama. 2005; 294: 1799-809.

162. Meijer WT, Grobbee DE, Hunink MG, Hofman A, Hoes AW. Determinants of peripheral arterial disease in the elderly: the Rotterdam study. Arch Intern Med. 2000; 160: 2934-8.

163. Green FR. Fibrinogen polymorphisms and atherothrombotic disease. Ann N Y Acad Sci. 2001; 936: 549-59.

164. van der Bom JG, de Maat MP, Bots ML, Haverkate F, de Jong PT, Hofman A, Kluft C, Grobbee DE. Elevated plasma fibrinogen: cause or consequence of cardiovascular disease? Arterioscler Thromb Vasc Biol. 1998; 18: 621-5.

165. Lim BC, Ariens RA, Carter AM, Weisel JW, Grant PJ. Genetic regulation of fibrin structure and function: complex gene-environment interactions may modulate vascular risk. Lancet. 2003; 361: 1424-31.

166. Scott EM, Ariens RA, Grant PJ. Genetic and environmental determinants of fibrin structure and function: relevance to clinical disease. Arterioscler Thromb Vasc Biol. 2004; 24: 1558-66.

167. Standeven KF, Grant PJ, Carter AM, Scheiner T, Weisel JW, Ariens RA. Functional analysis of the fibrinogen Aalpha Thr312Ala polymorphism: effects on fibrin structure and function. Circulation. 2003; 107: 2326-30.

168. Siegerink B, Rosendaal FR, Algra A. Genetic variation in fibrinogen; its relationship to fibrinogen levels and the risk of myocardial infarction and ischemic stroke. $J$ Thromb Haemost. 2009; 7: 385-90.

169. de Maat MP, Kastelein JJ, Jukema JW, Zwinderman AH, Jansen H, Groenemeier $\mathrm{B}$, Bruschke AV, Kluft C. $-455 \mathrm{G} / \mathrm{A}$ polymorphism of the beta-fibrinogen gene is associated with the progression of coronary atherosclerosis in symptomatic men: proposed role for an acute-phase reaction pattern of fibrinogen. REGRESS group. Arterioscler Thromb Vasc Biol. 1998; 18: 265-71.

170. Schmidt H, Schmidt R, Niederkorn K, Horner S, Becsagh P, Reinhart B, Schumacher M, Weinrauch V, Kostner GM. Beta-fibrinogen gene polymorphism $(\mathrm{C} 148-->\mathrm{T})$ is associated with carotid atherosclerosis: results of the Austrian Stroke Prevention Study. Arterioscler Thromb Vasc Biol. 1998; 18: 487-92.

171. Chen X, Xu M, Jin L, Chen J, Chen W. Association of beta-fibrinogen gene -148C/T and $-455 \mathrm{G} / \mathrm{A}$ polymorphisms and coronary artery disease in Chinese population: a meta analysis. Sci China C Life Sci. 2008; 51: 814-20.

172. Zito F, Di Castelnuovo A, Amore C, D'Orazio A, Donati MB, lacoviello L. Bcl I polymorphism in the fibrinogen beta-chain gene is associated with the risk of familial myocardial infarction by increasing plasma fibrinogen levels. A case-control study in a sample of GISSI-2 patients. Arterioscler Thromb Vasc Biol. 1997; 17: 3489-94. 
173. van Goor MP, Gomez-Garcia EB, Leebeek FW, Brouwers GJ, Koudstaal PJ, Dippel $\mathrm{DW}$. The -148 C/T fibrinogen gene polymorphism and fibrinogen levels in ischaemic stroke: a case-control study. J Neurol Neurosurg Psychiatry. 2005; 76: 121-3.

174. Tybjaerg-Hansen A, Agerholm-Larsen B, Humphries SE, Abildgaard S, Schnohr P, Nordestgaard BG. A common mutation (G-455--> A) in the beta-fibrinogen promoter is an independent predictor of plasma fibrinogen, but not of ischemic heart disease. A study of 9,127 individuals based on the Copenhagen City Heart Study. J Clin Invest. 1997; 99: 3034-9.

175. Collet JP, Nagaswami C, Farrell DH, Montalescot G, Weisel JW. Influence of gamma' fibrinogen splice variant on fibrin physical properties and fibrinolysis rate. Arterioscler Thromb Vasc Biol. 2004; 24: 382-6.

176. Cheung EY, Uitte de Willige S, Vos HL, Leebeek FW, Dippel DW, Bertina RM, de Maat MP. Fibrinogen gamma' in ischemic stroke: a case-control study. Stroke. 2008; 39: 1033-5.

177. Mannila MN, Lovely RS, Kazmierczak SC, Eriksson P, Samnegard A, Farrell DH, Hamsten A, Silveira A. Elevated plasma fibrinogen gamma' concentration is associated with myocardial infarction: effects of variation in fibrinogen genes and environmental factors. J Thromb Haemost. 2007; 5: 766-73.

178. Girolami A, Ruzzon E, Tezza F, Scandellari R, Vettore S, Girolami B. Arterial and venous thrombosis in rare congenital bleeding disorders: a critical review. Haemophilia. 2006; 12: 345-51.

179. Lak M, Keihani M, Elahi F, Peyvandi F, Mannucci PM. Bleeding and thrombosis in 55 patients with inherited afibrinogenaemia. Br J Haematol. 1999; 107: 204-6.

180. Acharya SS, Dimichele DM. Rare inherited disorders of fibrinogen. Haemophilia. 2008; 14: 1151-8.

181. Roberts HR, Stinchcombe TE, Gabriel DA. The dysfibrinogenaemias. $\mathrm{Br} J$ Haematol. 2001; 114: 249-57.

182. Koopman J, Haverkate F, Lord ST, Grimbergen J, Mannucci PM. Molecular basis of fibrinogen Naples associated with defective thrombin binding and thrombophilia. Homozygous substitution of B beta 68 Ala----Thr. J Clin Invest. 1992; 90: 238-44.

183. Lounes KC, Soria C, Mirshahi SS, Desvignes P, Mirshahi M, Bertrand O, Bonnet P, Koopman J, Soria J. Fibrinogen Ales: a homozygous case of dysfibrinogenemia (gamma-Asp(330)-->Val) characterized by a defective fibrin polymerization site "a". Blood. 2000; 96: 3473-9.

184. Muszbek L, Bagoly Z, Bereczky Z, Katona E. The involvement of blood coagulation factor XIII in fibrinolysis and thrombosis. Cardiovasc Hematol Agents Med Chem. 2008; 6: 190-205.

185. Komanasin N, Catto AJ, Futers TS, van Hylckama Vlieg A, Rosendaal FR, Ariens RA. A novel polymorphism in the factor XIII B-subunit (His95Arg): relationship to subunit dissociation and venous thrombosis. J Thromb Haemost. 2005; 3: 2487-96.

186. Kohler HP, Stickland MH, Ossei-Gerning N, Carter A, Mikkola H, Grant PJ. Association of a common polymorphism in the factor XIII gene with myocardial infarction. Thromb Haemost. 1998; 79: 8-13.

187. Rallidis LS, Politou M, Komporozos C, Panagiotakos DB, Belessi Cl, Travlou A, Lekakis J, Kremastinos DT. Factor XIII Val34Leu polymorphism and the risk of myocardial infarction under the age of 36 years. Thromb Haemost. 2008; 99: 10859.

188. Hancer VS, Diz-Kucukkaya R, Bilge AK, Ozben B, Oncul A, Ergen G, Nalcaci M. The association between factor XIII Val34Leu polymorphism and early myocardial infarction. Circ J. 2006; 70: 239-42. 
189. Franco RF, Pazin-Filho A, Tavella MH, Simoes MV, Marin-Neto JA, Zago MA. Factor XIII val34leu and the risk of myocardial infarction. Haematologica. 2000; 85: 67-71.

190. Aleksic N, Ahn C, Wang YW, Juneja H, Folsom AR, Boerwinkle E, Wu KK. Factor XIIIA Val34Leu polymorphism does not predict risk of coronary heart disease: The Atherosclerosis Risk in Communities (ARIC) Study. Arterioscler Thromb Vasc Biol. 2002; 22: 348-52.

191. Canavy I, Henry M, Morange PE, Tiret L, Poirier O, Ebagosti A, Bory M, JuhanVague I. Genetic polymorphisms and coronary artery disease in the south of France. Thromb Haemost. 2000; 83: 212-6.

192. Shafey M, Anderson JL, Scarvelis D, Doucette SP, Gagnon F, Wells PS. Factor XIII Val34Leu variant and the risk of myocardial infarction: a meta-analysis. Thromb Haemost. 2007; 97: 635-41.

193. Voko Z, Bereczky Z, Katona E, Adany R, Muszbek L. Factor XIII Val34Leu variant protects against coronary artery disease. A meta-analysis. Thromb Haemost. 2007; 97: 458-63.

194. Pruissen DM, Slooter AJ, Rosendaal FR, van der Graaf Y, Algra A. Coagulation factor XIII gene variation, oral contraceptives, and risk of ischemic stroke. Blood. 2008; 111: 1282-6.

195. Reiner AP, Heckbert SR, Vos HL, Ariens RA, Lemaitre RN, Smith NL, Lumley T, Rea TD, Hindorff LA, Schellenbaum GD, Rosendaal FR, Siscovick DS, Psaty BM. Genetic variants of coagulation factor XIII, postmenopausal estrogen therapy, and risk of nonfatal myocardial infarction. Blood. 2003; 102: 25-30.

196. Meltzer ME, Doggen CJ, de Groot PG, Rosendaal FR, Lisman T. Fibrinolysis and the risk of venous and arterial thrombosis. Curr Opin Hematol. 2007; 14: 242-8.

197. Lowe GD, Danesh J, Lewington S, Walker M, Lennon L, Thomson A, Rumley A, Whincup $\mathrm{PH}$. Tissue plasminogen activator antigen and coronary heart disease. Prospective study and meta-analysis. Eur Heart J. 2004; 25: 252-9.

198. Ladenvall $P$, Wall U, Jern S, Jern C. Identification of eight novel single-nucleotide polymorphisms at human tissue-type plasminogen activator (t-PA) locus: association with vascular t-PA release in vivo. Thromb Haemost. 2000; 84: 150-5.

199. Ladenvall $P$, Johansson L, Jansson JH, Jern S, Nilsson TK, Tjarnlund A, Jern C, Boman K. Tissue-type plasminogen activator $-7,351 \mathrm{C} / \mathrm{T}$ enhancer polymorphism is associated with a first myocardial infarction. Thromb Haemost. 2002; 87: 105-9.

200. Jood K, Ladenvall $P$, Tjarnlund-Wolf $A$, Ladenvall $C$, Andersson M, Nilsson S, Blomstrand C, Jern C. Fibrinolytic gene polymorphism and ischemic stroke. Stroke. 2005; 36: 2077-81.

201. van der Bom JG, de Knijff P, Haverkate F, Bots ML, Meijer P, de Jong PT, Hofman A, Kluft C, Grobbee DE. Tissue plasminogen activator and risk of myocardial infarction. The Rotterdam Study. Circulation. 1997; 95: 2623-7.

202. Steeds R, Adams M, Smith P, Channer K, Samani NJ. Distribution of tissue plasminogen activator insertion/deletion polymorphism in myocardial infarction and control subjects. Thromb Haemost. 1998; 79: 980-4.

203. Ridker PM, Baker MT, Hennekens CH, Stampfer MJ, Vaughan DE. Alu-repeat polymorphism in the gene coding for tissue-type plasminogen activator (t-PA) and risks of myocardial infarction among middle-aged men. Arterioscler Thromb Vasc Biol. 1997; 17: 1687-90.

204. Frere C, Morange PE, Saut N, Tregouet DA, Grosley M, Beltran J, Juhan-Vague I, Alessi MC. Quantification of thrombin activatable fibrinolysis inhibitor (TAFI) gene polymorphism effects on plasma levels of TAFI measured with assays insensitive to isoform-dependent artefact. Thromb Haemost. 2005; 94: 373-9.

205. Segev A, Hegele RA, Lau HK, Sparkes JD, Teitel JM, Chisholm RJ, Strauss BH. Thr325lle polymorphism of the TAFI gene is related to TAFI antigen plasma levels 
and angiographic restenosis after percutaneous coronary interventions. Thromb Res. 2004; 114: 137-41.

206. Zorio E, Castello R, Falco C, Espana F, Osa A, Almenar L, Aznar J, Estelles A. Thrombin-activatable fibrinolysis inhibitor in young patients with myocardial infarction and its relationship with the fibrinolytic function and the protein $\mathrm{C}$ system. Br J Haematol. 2003; 122: 958-65.

207. Peetz D, Victor A, Adams P, Erbes H, Hafner G, Lackner KJ, Hoehler T. Genetic and environmental influences on the fibrinolytic system: a twin study. Thromb Haemost. 2004; 92: 344-51.

208. Henry M, Aubert H, Morange PE, Nanni I, Alessi MC, Tiret L, Juhan-Vague I. Identification of polymorphisms in the promoter and the 3 ' region of the TAFI gene: evidence that plasma TAFI antigen levels are strongly genetically controlled. Blood. 2001; 97: 2053-8.

209. de Bruijne EL, Gils A, Guimaraes AH, Dippel DW, Deckers JW, van den Meiracker $\mathrm{AH}$, Poldermans D, Rijken DC, Declerck PJ, de Maat MP, Leebeek FW. The role of thrombin activatable fibrinolysis inhibitor in arterial thrombosis at a young age: the ATTAC study. J Thromb Haemost. 2009; 7: 919-27.

210. Tassies D, Roque M, Monteagudo J, Martorell T, Sionis A, Arzamendi D, Heras M, Reverter JC. Thrombin-activatable fibrinolysis inhibitor genetic polymorphisms as markers of the type of acute coronary syndrome. Thromb Res. 2009; 124: 614-8.

211. Morange PE, Tregouet DA, Frere C, Luc G, Arveiler D, Ferrieres J, Amouyel P, Evans $A$, Ducimetiere $P$, Cambien $F$, Tiret $L$, Juhan-Vague I. TAFI gene haplotypes, TAFI plasma levels and future risk of coronary heart disease: the PRIME Study. J Thromb Haemost. 2005; 3: 1503-10.

212. Juhan-Vague I, Morange PE, Aubert $H$, Henry M, Aillaud MF, Alessi MC, Samnegard A, Hawe E, Yudkin J, Margaglione M, Di Minno G, Hamsten A, Humphries SE. Plasma thrombin-activatable fibrinolysis inhibitor antigen concentration and genotype in relation to myocardial infarction in the north and south of Europe. Arterioscler Thromb Vasc Biol. 2002; 22: 867-73.

213. Kohler HP, Grant PJ. Plasminogen-activator inhibitor type 1 and coronary artery disease. N Engl J Med. 2000; 342: 1792-801.

214. Naran $\mathrm{NH}$, Chetty $\mathrm{N}$, Crowther NJ. The influence of metabolic syndrome components on plasma PAI-1 concentrations is modified by the PAI-1 4G/5G genotype and ethnicity. Atherosclerosis. 2008; 196: 155-63.

215. Verschuur M, Jellema A, Bladbjerg EM, EJ MF, Mensink RP, Moller L, Vos HL, de Maat MP. The plasminogen activator inhibitor-1 (PAI-1) promoter haplotype is related to PAl-1 plasma concentrations in lean individuals. Atherosclerosis. 2005; 181: 275-84.

216. Hoekstra T, Geleijnse JM, Schouten EG, Kluft C. Plasminogen activator inhibitortype 1: its plasma determinants and relation with cardiovascular risk. Thromb Haemost. 2004; 91: 861-72.

217. Roncal C, Orbe J, Belzunce M, Rodriguez JA, Paramo JA. The 4G/5G PAI-1 polymorphism influences the endothelial response to IL-1 and the modulatory effect of pravastatin. J Thromb Haemost. 2006; 4: 1798-803.

218. Perez-Martinez P, Adarraga-Cansino MD, Fernandez de la Puebla RA, BlancoMolina A, Delgado-Lista J, Marin C, Ordovas JM, Lopez-Miranda J, Perez-Jimenez F. The $-6754 \mathrm{G} / 5 \mathrm{G}$ polymorphism at the Plasminogen Activator Inhibitor 1 (PAI-1) gene modulates plasma Plasminogen Activator Inhibitor 1 concentrations in response to dietary fat consumption. Br J Nutr. 2008; 99: 699-702.

219. Boncoraglio GB, Bodini A, Brambilla C, Carriero MR, Ciusani E, Parati EA. An effect of the PAI-1 4G/5G polymorphism on cholesterol levels may explain conflicting associations with myocardial infarction and stroke. Cerebrovasc Dis. 2006; 22: 191-5. 


\section{Chapter 8}

220. Drinane M, Mollmark J, Zagorchev L, Moodie K, Sun B, Hall A, Shipman S, Morganelli $\mathrm{P}$, Simons $\mathrm{M}$, Mulligan-Kehoe MJ. The antiangiogenic activity of rPAI1(23) inhibits vasa vasorum and growth of atherosclerotic plaque. Circ Res. 2009; 104: 337-45.

221. Qian HS, Gu JM, Liu P, Kauser K, Halks-Miller M, Vergona R, Sullivan ME, Dole WP, Deng GG. Overexpression of PAl-1 prevents the development of abdominal aortic aneurysm in mice. Gene Ther. 2008; 15: 224-32.

222. Corsetti JP, Ryan D, Moss AJ, Rainwater DL, Zareba W, Sparks CE. Plasminogen activator inhibitor-1 polymorphism $(4 \mathrm{G} / 5 \mathrm{G})$ predicts recurrence in nonhyperlipidemic postinfarction patients. Arterioscler Thromb Vasc Biol. 2008; 28: 548-54.

223. Boekholdt SM, Bijsterveld NR, Moons AH, Levi M, Buller HR, Peters RJ. Genetic variation in coagulation and fibrinolytic proteins and their relation with acute myocardial infarction: a systematic review. Circulation. 2001; 104: 3063-8.

224. Martinelli N, Trabetti E, Pinotti M, Olivieri O, Sandri M, Friso S, Pizzolo F, Bozzini C, Caruso PP, Cavallari U, Cheng S, Pignatti PF, Bernardi F, Corrocher R, Girelli $D$. Combined effect of hemostatic gene polymorphisms and the risk of myocardial infarction in patients with advanced coronary atherosclerosis. PLoS One. 2008; 3: e1523.

225. Attia J, Thakkinstian A, Wang Y, Lincz L, Parsons M, Sturm J, McGettigan P, Scott $\mathrm{R}$, Meldrum C, Levi C. The PAI-1 4G/5G gene polymorphism and ischemic stroke: an association study and meta-analysis. J Stroke Cerebrovasc Dis. 2007; 16: 1739.

226. Rao R, Tah V, Casas JP, Hingorani A, Whittaker J, Smeeth L, Sharma P. Ischaemic stroke subtypes and their genetic basis: a comprehensive meta-analysis of small and large vessel stroke. Eur Neurol. 2009; 61: 76-86. 


\section{Chapter 9}

General discussion 

The focus of this thesis is the role of the contact activation system, mainly coagulation factor XII (FXII), in fibrin clot formation and fibrinolysis. Chapters 2, 3 and 4 described mainly in vitro work. In these chapters, the contribution of FXII(a) to fibrin clot formation and fibrinolysis were assessed. In chapters 5, 6 and 7 patient studies were described. We determined the contribution of the enzymes of the contact system in acute myocardial infarction (AMI) and hereditary angioedema (HAE-C1INH). In patients with $\mathrm{HAE}-\mathrm{C} 1 \mathrm{INH}$ the regulation of the contact system is affected, without changing the thrombotic risk. Furthermore, the role of fibrin formation and fibrinolysis in patients with stent thrombosis was determined.

\section{Factor XII in clot formation and fibrinolysis}

Factor XII was discovered in 1955, however the in vivo contribution of this protein is still not fully understood [1]. Patients with a deficiency in FXII neither have a bleeding tendency nor appear to have an increased risk for thrombosis. After the findings of the Josso loop (activation of FIX by the TF/FVIla complex) [2] and the feedback loop of FXI activation by thrombin [3], FXII was seen as an unimportant factor in coagulation. However, in 2005 the interest in FXII was renewed when Renné et al observed that $\mathrm{FXII}^{-/}$mice have a defective thrombus formation [4]. Using several thrombotic models, in $\mathrm{FXII}^{-1-}$ mice or with the use of FXIla-inhibitors, it was shown that in mice, FXII is essential for thrombus formation [4-6]. Furthermore, inhibiting the activation of FXI by FXIla proved to protect against thrombosis in mice and in primates [6,7]. However, data from clinical studies are less straightforward, as was reviewed in the introduction of this thesis. Low levels of FXII-zymogen, as well as elevated levels of the enzyme FXIla have been found to be a risk factor for arterial thrombosis [8,9]. Furthermore, low as well as high levels of FXIla in complex with C1-esterase inhibitor $(\mathrm{C} 1 \mathrm{INH})$ were associated with an increased risk of AMI [10]. In contrast, several other studies did not find a contribution of FXII to arterial thrombosis [11,12]. The evident contribution of FXII to thrombosis in animal studies, as well as the conflicting data between the different clinical studies prompted us to explore other contributions of FXII in thrombosis independent from the activation of the intrinsic pathway of coagulation by FXIla.

\section{Fibrin clot formation}

The structure of the fibrin clot is an important determinant of thrombotic risk [13]. Clinical studies have shown that clots made from plasma of thrombotic patients have an altered fibrin structure. Changes in the fibrin network have 


\section{Chapter 9}

been observed in patients with arterial [14] as well as venous thrombosis [15], but also in apparently healthy relatives of thrombotic patients $[15,16]$. Clots from patients with arterial or venous thrombosis are mainly characterized by a dense network of thin fibrin fibers, a reduced permeability of the clot and an increased resistance to fibrinolysis [13]. Several determinants of such a "pro-thrombotic" clot have been identified, such as concentration of thrombin or fibrinogen splice variants $[17,18]$. However, these determinants cannot explain all variations in clot structure [14]. Therefore, we investigated whether FXII and its activated forms could be additional determinants of fibrin structure.

In a purified system, we observed that $\alpha-F X I l a$ was able to change the fibrin clot structure: in the presence of $\alpha$-FXlla fibrin clots were stiffer and were composed of thinner fibers which were more densely arranged. This action of $\alpha$-FXIla was dependent on its enzymatic activity: the zymogen FXII did not change fibrin structure and inhibition of the enzymatic activity of $\alpha$-FXlla by corn trypsin inhibitor (CTI) or H-D-Phe-Pro-Arg-chloromethylketone (PPACK) abolished the effect of $\alpha$-FXIla. In a plasma-based system, we showed that FXIla increased the clot density via two routes: 1) by interaction with fibrin(ogen) and 2) via activation of the intrinsic pathway of coagulation and thrombin formation. Binding studies revealed that FXII and $\alpha-F X I l a$ bind via the heavy chain to fibrinogen and fibrin. We did not determine where $\alpha$-FXIla binds specifically to the fibrinogen molecule. FXII is strongly homologous to tissue plasminogen activator (tPA), which binds to the aC-domain of the fibrin molecule that is involved in the lateral aggregation of protofibrils into fibers [19]. Due to the homology of FXII and TPA and the changes in lag phase observed in the presence of $\alpha-\mathrm{FXIla}$, we hypothesize that binding of FXII to the aC-domain of the fibrinogen molecule is responsible for the observed changes in fibrin structure. Furthermore, in the Second Northwick Park Heart Study (NPHS-II) a strong correlation was observed between the levels of FXIla and the levels of fibrinopeptide A (FPA), suggesting that FXIla might influence the cleavage of FPA from fibrinogen [20].

\section{Fibrinolysis}

One of the main reasons fibrin clot structure is such an important determinant of thrombotic risk is that it influences the susceptibility of the clot to fibrinolysis. The changes in fibrin structure we observed in the presence of $\alpha$-FXIla are characteristic of a clot, which is less susceptible to fibrinolysis. Already in 1959 it was discovered that FXII also contributes to fibrinolysis: activation of FXII by kaolin increased the euglobulin fibrinolytic activity of the plasma [21]. Later, it was found that FXIla is able to convert plasminogen into plasmin [22]. 
Furthermore, kallikrein and FXla can also activate plasminogen [23,24]. Thus, FXIla also contributes to fibrinolysis via the activation of FXI and prekallikrein. However, the enzymes of the contact system are less efficient in the activation of plasminogen than tPA or urokinase plasminogen activator (UPA) [25]. Therefore, the significance of the contact system to fibrinolysis in vivo is uncertain. Few studies determined the contribution of FXIla to fibrinolysis in vivo. In a septic baboon model, inhibition of FXIla with a monoclonal antibody reduced the activity of the fibrinolytic system [26]. Furthermore, infusion of desamino D-arginine vasopressin (DDAVP), which releases IPA and UPA from the vessel wall and activates the contact system, led to less plasmin generation in FXII-deficient patients compared to healthy controls. In healthy controls, the potential to activate plasminogen after infusion of DDAVP was only partially blocked by specific inhibitors of IPA and uPA. The residual activity could be blocked with a monoclonal antibody that inhibits FXII activity $[27,28]$.

We determined the influence of $\alpha$-FXlla on fibrinolysis using several approaches. First, we confirmed that $\alpha-F X I l a$ is able to convert plasminogen into plasmin. Next, using different techniques to address fibrinolysis, we showed a dose dependent increase in fibrinolysis in the presence of $\alpha$-FXlla. This increase in fibrinolysis was dependent on the conversion of plasminogen into plasmin, since no fibrinolysis occurred in the absence of plasminogen and the formation of plasmin and fibrinolysis occurred simultaneously.

Our results show that FXII has a dual function in coagulation and fibrinolysis. During clot formation, as was recognized decades ago, $\alpha$-FXIla activates FXI and via sequential activation of coagulation factors $\mathrm{XI}$, IX, and $\mathrm{X}$, thrombin is formed. We have shown that the level of thrombin generated was dependent on the concentration of FXII present in plasma. Furthermore, FXII and a-FXIla bound to fibrinogen and fibrin and a-FXIla was able to change the structure of the formed fibrin clot. Under the influence of $\alpha$-FXIla the fibrin fibers became thinner and the clot became denser and more rigid. Recently, it was shown that FXIla can activate prothrombin, independently from FXI activation [29]. These actions of FXII during clot formation all predispose to make a denser and stronger clot. During fibrinolysis, FXIla is able to convert plasminogen to plasmin and to activate $\mathrm{FXI}$ and prekallikrein which are also able to activate plasminogen. We have shown that $\alpha-F X I l a$ enhanced fibrinolysis in the presence of low levels of tPA. Additionally, since $\alpha$-FXIla and plasminogen bind to fibrin, the presence of these proteins at the fibrin surface will initiate fibrinolysis at the start of fibrinolysis when only low levels of tPA are present. 


\section{Chapter 9}

Presumably, when the tPA concentration increases, the contribution of $\alpha$-FXIla to fibrinolysis will be negligible.

This dual effect of FXII in coagulation and fibrinolysis, may explain the differences observed between clinical studies. In our view, low levels of FXIla will predispose to a weak clot and reduced fibrinolysis whereas high levels of FXIla will predispose to a dense clot and increased fibrinolysis. In both situations, a pro-thrombotic (reduced fibrinolysis or dense clot) and an anti-thrombotic (weak clot or increased fibrinolysis) condition are present. Therefore, it depends on the moment of FXII-activation (during fibrin clot formation or during fibrinolysis) when FXIla is active. Factors influencing the activation of FXII, hereby may determine whether $\alpha$-FXIla predominantly contributes to coagulation or to fibrinolysis.

\section{Arterial thrombosis}

\section{Acute myocardial infarction}

The contribution of FXII to arterial thrombosis in humans is not clear. Several clinical studies determined the role FXII(a) in arterial thrombosis, but the results of these studies differ. To get more insight in the contribution of the contact system in AMI, we measured activation of the contact system at different time points during and after the acute event (in the steady-state phase). In a cohort of patients admitted to the hospital with a first AMI we measured the levels of activated proteins of the contact system in complex with the physiological inhibitors C1INH (FXIla-C1INH, kallikrein-C1INH, FXla-C1INH) and $a_{1-}$ antitrypsin (FXla-AT). We measured these levels during the acute thrombotic event, and 3 months and 6 months after the event. The levels of the enzyme inhibitory complexes did not predict the occurrence of a recurrent event. The levels of FXla-C1INH were elevated during the acute event and declined 3 and 6 months after the event. However, the levels of FXIla-C1INH did not change over time. Therefore, in our study it seemed that activation of FXII did not contribute to the development of the AMI. Probably, activation of FXI during the AMI resulted from increased thrombin generation [30].

\section{Stent thrombosis}

The structure of plasma clots and their susceptibility to fibrinolysis are known determinants of arterial thrombosis. Plasma clots from patients with arterial thrombosis have a dense fibrin network and are resistant to fibrinolysis [13]. However, little is known about the influence of fibrin structure and fibrinolysis in 
patients with coronary stent thrombosis (ST). One case-control study investigated the effect of the fibrin clot structure and fibrinolysis in these patients $[31,32]$. They observed that clots made from plasma of percutaneous coronary intervention ( $\mathrm{PCl}$ ) patients that develop ST form denser plasma clots, which are more difficult to lyse. We set up a case-control study in patients with ST and measured fibrin clot formation and fibrinolysis via turbidity. We did not observe a difference in fibrin clot formation (the lag time and the maximal absorbance) or in fibrinolysis (clot lysis time) between cases and controls. We recognize several differences between our study and the previous study of Undas et al. [31]. The cases in our study suffered mainly from late ST (more than $50 \%$ ), whereas in the previous study $13 \%$ of cases had a late ST. Furthermore, due to changes in clinical practice, mostly drug-eluting stents (DES) were placed in our study, compared to mostly bare metal stents (BMS) in the previous study [31]. Together with differences between the methods and the baseline characteristics of the study population, this could explain the discrepancy in results between these studies.

We did not measure activation of the contact system in this patient population. However, previously it was shown that (very) late stent thrombosis was not associated with systemic activation of the contact system [33].

\section{Hereditary angioedema}

How and when FXII(a) contributes to thrombosis is not fully understood, however, uncontrolled activation of the contact system is associated with angioedema rather than with thrombosis. HAE is a disease most often caused by a deficiency in $\mathrm{C} 1 \mathrm{INH}$ (HAE-C1INH) [34]. C1INH is the most important inhibitor of the contact activation system: $90 \%$ of FXIla, $50 \%$ of kallikrein and $50 \%$ of FXla are inhibited by $\mathrm{C} 1 \mathrm{INH}$ in plasma [35-37]. Due to poor regulation of the kinin system in these patients, an excess of bradykinin is formed which induces episodic attacks of angioedema. However, patients with HAE-C1INH have no apparent increased tendency to thrombosis, even though activation of the coagulation system is observed $[38,39]$. We investigated if contact activation in HAE-C1INH patients mainly leads to the activation of prekallikrein (and bradykinin formation) and less to FXI activation, but showed that this was not the case. Both prekallikrein and FXI were partly consumed, indicating in vivo activation of the contact system. The absence of thrombotic complications is probably due to the regulation of the coagulation cascade via other inhibitors and/or increased fibrinolysis. We observed higher levels of FXI in complex with $\alpha_{1}$-antitrypin (AT) after activation of the plasma. Furthermore, increased 
fibrinolysis was observed in HAE-C1INH patients [40-42]. C1INH is able to inhibit the fibrinolytic activity of FXIla [43], but also directly inhibits plasmin [44]. In HAE-C1INH, both the pro-coagulant and the pro-fibrinolytic functions of FXIla are enhanced due to poor regulation. Nonetheless, the main problem in these patients is an increased bradykinin formation. This highlights that excess contact activation with generation of FXIla is in itself not sufficient to evoke thrombosis and other contributing risk factors should be present.

\section{FXIla-inhibitors}

Since the finding that FXII-deficient mice have impaired thrombus formation [4], the use of FXIla-inhibitors as therapy to prevent thrombosis has been considered $[45,46]$. Since FXII is not essential for hemostasis, apparent from the fact that FXII-deficient patients do not have a bleeding tendency, inhibiting FXIla will probably not lead to bleeding complications, which is a major side effect of today's anticoagulants. We tested the monoclonal antibody (mAb) 3F7 against FXIla in in vitro tests in whole blood and platelet poor plasma (PPP). In ROTEM and turbidity experiments we observed that the mAb increased the clotting time and made the clot weaker, when we initiated coagulation via FXII activation. In whole blood ROTEM experiments, the clot lysis time was slightly prolonged in the presence of $100 \mu \mathrm{g} / \mathrm{ml} \mathrm{mAb}$ both when coagulation was initiated via FXII-activation or with tissue factor. Other FXIla-inhibitors have been tested in in vivo models. rHA-Infestin-4 is a serine protease inhibitor derived from the hematophagous insect Triatoma infestans and is a strong inhibitor of FXIla [47,48]. In thrombosis models, it was shown that rHA-Infestin-4 was able to prevent arterial thrombus formation in mice and rats, and to protect mice against ischemic brain injury and silent brain ischemia $[47,48]$. The protective effect of rHA-Infestin-4 in these models was accomplished by abolishing platelet aggregation and thrombus formation [48]. Ixodes ricinus contact phase inhibitor (Ir-CPI) is derived from the tick Ixodes ricinus, has one Kunitz domain and is capable of effectively inhibiting the intrinsic pathway of coagulation. Ir-CPI binds with high affinity to FXIla, FXla and kallikrein and prevents their enzymatic activity [49]. Mice treated with Ir-CPI were protected from induced venous and arterial thrombosis. Ir-CPI mainly attenuated clot propagation and impaired the formation and stabilization of platelet-rich thrombi [49]. However, both rHA-Infestin-4 and Ir-CPI moderately inhibited fibrinolysis, which is unwanted since reduced fibrinolysis in itself may be a risk factor for thrombosis [50]. Whether mAb 3F7 affects fibrinolysis is still under investigation. 
As an alternative to inhibition of FXIla, the mAb 14E11, which only inhibits FXI activation by FXIla but not FXI activation by thrombin has been used. Mice and baboons treated with this $\mathrm{mAb}$ were protected against experimentally induced thrombus formation and acute ischemic stroke [6,7]. Other functions of FXIla and the activation of FXI by thrombin are not inhibited by this $\mathrm{mAb}$.

\section{Conclusions and future perspective}

In this thesis, we have shown that FXII has a dual role in coagulation and fibrinolysis. During clot formation, FXIla changed the structure and properties of the fibrin clot. a-FXIla was able to activate the coagulation pathway and interacted with fibrin(ogen). Activation of the coagulation pathway led to thrombin formation, in a concentration dependent manner: the more a-FXIla present, the more thrombin was formed which led to a denser fibrin clot. Interaction of $\alpha-F X I l a$ with fibrin(ogen) led to a denser, more rigid fibrin network, in a concentration dependent manner. This increase in fibrin clot density and rigidity could possibly help to prevent embolization, as was shown in $\mathrm{FXII}^{-/-}$mice [4]. During fibrinolysis, $\alpha-F X I l a$ converted plasminogen, which both can bind to the fibrin network, into plasmin. Hereby, $\alpha$-FXIla helped to initiate fibrinolysis at low levels of tPA. Since tPA is much more efficient in converting plasminogen into plasmin, once the concentration of TPA increases the contribution of $\alpha$-FXIla to plasmin formation will be minimal. Our experiments were performed in vitro, therefore, in vivo studies are needed to confirm this time dependent effect of FXII.

In recent years, FXII has emerged as a therapeutic target for the treatment and prevention of arterial thrombosis. Several FXIla-inhibitors have been tested in animal models with good results: inhibition of FXIla was shown to protect from experimentally induced thrombosis at different sites in the body and in several species without increasing the risk of bleeding [5,6,47-49]. However, none of these inhibitors have been tested in humans at this point. Since FXII participates in several physiological processes apart from activation of the coagulation cascade (e.g. fibrinolysis, bradykinin formation and angiogenesis), it is important to monitor the occurrence of side effects of these inhibitors. Alternatively, the activation of FXI by FXIla can be inhibited with mAb 14E11, without interfering in other enzymatic actions of FXIla [6]. A disadvantage of this approach is that the direct interaction of $\alpha-F X I l a$, leading to a denser fibrin clot, will not be inhibited. 


\section{Chapter 9}

It should be noted that several clinical studies (including our study in patients with a first AMI) do not find an association between FXII(a)-levels and thrombosis. Furthermore, patients with $\mathrm{HAE}-\mathrm{C} 1 \mathrm{INH}$ do not have an increased thrombotic risk despite activation of the contact system. Therefore, not in all patients inhibition of FXIla will be sufficient to prevent thrombosis. Before FXIlainhibitors can be widely used as an anti-thrombotic strategy, it is important to identify those patients in which FXIla-inhibition is potentially helpful. To ultimately determine if inhibition of FXIla is a suitable manner to prevent thrombosis, clinical trials are needed. 


\section{References}

1. Ratnoff OD, Margolius A, Jr. Hageman trait: an asymptomatic disorder of blood coagulation. Trans Assoc Am Physicians. 1955; 68: 149-54.

2. Osterud B, Rapaport SI. Activation of factor IX by the reaction product of tissue factor and factor VII: additional pathway for initiating blood coagulation. Proceedings of the National Academy of Sciences of the United States of America. 1977; 74: 5260-4.

3. Gailani D, Broze GJ, Jr. Factor XI activation in a revised model of blood coagulation. Science. 1991; 253: 909-12.

4. Renne T, Pozgajova M, Gruner S, Schuh K, Pauer HU, Burfeind P, Gailani D, Nieswandt B. Defective thrombus formation in mice lacking coagulation factor XII. $J$ Exp Med. 2005; 202: 271-81.

5. Kleinschnitz C, Stoll G, Bendszus M, Schuh K, Pauer HU, Burfeind P, Renne C, Gailani D, Nieswandt B, Renne T. Targeting coagulation factor XII provides protection from pathological thrombosis in cerebral ischemia without interfering with hemostasis. J Exp Med. 2006; 203: 513-8.

6. Leung PY, Hurst S, Berny-Lang MA, Verbout NG, Gailani D, Tucker El, Wang RK, McCarty OJ, Gruber A. Inhibition of Factor XII-Mediated Activation of Factor XI Provides Protection Against Experimental Acute Ischemic Stroke in Mice. Translational stroke research. 2012; 3: 381-9.

7. Cheng Q, Tucker EI, Pine MS, Sisler I, Matafonov A, Sun MF, White-Adams TC, Smith SA, Hanson SR, McCarty OJ, Renne T, Gruber A, Gailani D. A role for factor XIla-mediated factor XI activation in thrombus formation in vivo. Blood. 2010; 116: 3981-9.

8. Cooper JA, Miller GJ, Bauer KA, Morrissey JH, Meade TW, Howarth DJ, Barzegar $S$, Mitchell JP, Rosenberg RD. Comparison of novel hemostatic factors and conventional risk factors for prediction of coronary heart disease. Circulation. 2000; 102: 2816-22.

9. Doggen CJ, Rosendaal FR, Meijers JC. Levels of intrinsic coagulation factors and the risk of myocardial infarction among men: Opposite and synergistic effects of factors XI and XII. Blood. 2006; 108: 4045-51.

10. Govers-Riemslag JW, Smid M, Cooper JA, Bauer KA, Rosenberg RD, Hack CE, Hamulyak K, Spronk HM, Miller GJ, ten Cate H. The plasma kallikrein-kinin system and risk of cardiovascular disease in men. J Thromb Haemost. 2007; 5: 1896-903.

11. Lowe GD, Rumley A, McMahon AD, Ford I, O'Reilly DS, Packard CJ. Interleukin-6, fibrin D-dimer, and coagulation factors VII and XIla in prediction of coronary heart disease. Arterioscler Thromb Vasc Biol. 2004; 24: 1529-34.

12. Merlo C, Wuillemin WA, Redondo M, Furlan M, Sulzer I, Kremer-Hovinga J, Binder BR, Lammle B. Elevated levels of plasma prekallikrein, high molecular weight kininogen and factor XI in coronary heart disease. Atherosclerosis. 2002; 161: 2617.

13. Undas A, Ariens RA. Fibrin clot structure and function: a role in the pathophysiology of arterial and venous thromboembolic diseases. Arterioscler Thromb Vasc Biol. 2011; 31: e88-99.

14. Collet JP, Allali Y, Lesty C, Tanguy ML, Silvain J, Ankri A, Blanchet B, Dumaine R, Gianetti J, Payot L, Weisel JW, Montalescot G. Altered fibrin architecture is associated with hypofibrinolysis and premature coronary atherothrombosis. Arterioscler Thromb Vasc Biol. 2006; 26: 2567-73.

15. Undas A, Zawilska K, Ciesla-Dul M, Lehmann-Kopydlowska A, Skubiszak A, Ciepluch K, Tracz W. Altered fibrin clot structure/function in patients with idiopathic venous thromboembolism and in their relatives. Blood. 2009; 114: 4272-8. 
16. Bhasin N, Ariens RA, West RM, Parry DJ, Grant PJ, Scott DJ. Altered fibrin clot structure and function in the healthy first-degree relatives of subjects with intermittent claudication. Journal of vascular surgery. 2008; 48: 1497-503, 503 e1.

17. Cooper AV, Standeven KF, Ariens RA. Fibrinogen gamma-chain splice variant gamma' alters fibrin formation and structure. Blood. 2003; 102: 535-40.

18. Wolberg AS. Determinants of fibrin formation, structure, and function. Curr Opin Hematol. 2012; 19: 349-56.

19. Gorkun OV, Veklich YI, Medved LV, Henschen AH, Weisel JW. Role of the alpha C domains of fibrin in clot formation. Biochemistry. 1994; 33: 6986-97.

20. Zito F, Drummond F, Bujac SR, Esnouf MP, Morrissey JH, Humphries SE, Miller GJ. Epidemiological and genetic associations of activated factor XII concentration with factor VII activity, fibrinopeptide A concentration, and risk of coronary heart disease in men. Circulation. 2000; 102: 2058-62.

21. Niewiarowski S, Prou-Wartelle O. [Role of the contact factor (Hageman factor) in fibrinolysis]. Thrombosis et diathesis haemorrhagica. 1959; 3: 593-603.

22. Goldsmith GH, Jr., Saito H, Ratnoff OS. The activation of plasminogen by Hageman factor (Factor XII) and Hageman factor fragments. J Clin Invest. 1978; 62: 54-60.

23. Colman RW. Activation of plasminogen by human plasma kallikrein. Biochem Biophys Res Commun. 1969; 35: 273-9.

24. Mandle RJ, Jr., Kaplan AP. Hageman-factor-dependent fibrinolysis: generation of fibrinolytic activity by the interaction of human activated factor $\mathrm{XI}$ and plasminogen. Blood. 1979; 54: 850-62.

25. Miles LA, Greengard JS, Griffin JH. A comparison of the abilities of plasma kallikrein, beta-Factor XIla, Factor Xla and urokinase to activate plasminogen. Thromb Res. 1983; 29: 407-17.

26. Jansen PM, Pixley RA, Brouwer M, de Jong IW, Chang AC, Hack CE, Taylor FB, Jr., Colman RW. Inhibition of factor XII in septic baboons attenuates the activation of complement and fibrinolytic systems and reduces the release of interleukin- 6 and neutrophil elastase. Blood. 1996; 87: 2337-44.

27. Levi M, Hack CE, de Boer JP, Brandjes DP, Buller HR, ten Cate JW. Reduction of contact activation related fibrinolytic activity in factor XII deficient patients. Further evidence for the role of the contact system in fibrinolysis in vivo. J Clin Invest. 1991; 88: $1155-60$.

28. Levi M, Hack CE, de Boer JP, Brandjes DP, Buller HR, ten Cate JW. Contact system dependent fibrinolytic activity in vivo: observations in healthy subjects and factor XII deficient patients. Agents Actions Suppl. 1992; 38 ( Pt 2): 292-8.

29. Puy C, Tucker El, Wong ZC, Gailani D, Smith SA, Choi SH, Morrissey JH, Gruber A, McCarty OJ. Factor XII promotes blood coagulation independent of factor XI in the presence of long chain polyphosphate. J Thromb Haemost. 2013.

30. Smid M, Dielis AW, Winkens M, Spronk HM, van Oerle R, Hamulyak K, Prins MH, Rosing J, Waltenberger JL, ten Cate $\mathrm{H}$. Thrombin generation in patients with a first acute myocardial infarction. J Thromb Haemost. 2011; 9: 450-6.

31. Undas A, Zalewski J, Krochin M, Siudak Z, Sadowski M, Pregowski J, Dudek D, Janion M, Witkowski A, Zmudka K. Altered plasma fibrin clot properties are associated with in-stent thrombosis. Arterioscler Thromb Vasc Biol. 2010; 30: 27682.

32. Pankiw-Bembenek O, Zalewski J, Goralczyk T, Undas A. A history of early stent thrombosis is associated with prolonged clot lysis time. Thromb Haemost. 2012; 107: 513-20.

33. Ponitz V, Govers-Riemslag JW, Ten Cate $H$, van Oerle R, Brugger-Andersen $T$, Grundt H, Naesgaard P, Pritchard D, Larsen AI, Nilsen DW. A history of late and 
very late stent thrombosis is not associated with increased activation of the contact system, a case control study. Thrombosis journal. 2010; 8: 6 .

34. Longhurst $\mathrm{H}$, Cicardi $\mathrm{M}$. Hereditary angio-oedema. Lancet. 2012; 379: 474-81.

35. Pixley RA, Schapira M, Colman RW. The regulation of human factor Xlla by plasma proteinase inhibitors. J Biol Chem. 1985; 260: 1723-9.

36. van der Graaf F, Keus JF, Koedam JA, Rietveld A, Bouma BN. Prekallikrein activation and kallikrein inactivation in human plasma. Adv Exp Med Biol. 1983; 156: $143-8$.

37. Wuillemin WA, Minnema M, Meijers JC, Roem D, Eerenberg AJ, Nuijens JH, ten Cate $\mathrm{H}$, Hack $\mathrm{CE}$. Inactivation of factor $\mathrm{Xla}$ in human plasma assessed by measuring factor Xla-protease inhibitor complexes: major role for $\mathrm{C} 1$-inhibitor. Blood. 1995; 85: 1517-26.

38. Cugno M, Zanichelli A, Bellatorre AG, Griffini S, Cicardi M. Plasma biomarkers of acute attacks in patients with angioedema due to $\mathrm{C} 1$-inhibitor deficiency. Allergy. 2009; 64: 254-7.

39. Cugno M, Cicardi M, Bottasso B, Coppola R, Paonessa R, Mannucci PM, Agostoni A. Activation of the coagulation cascade in C1-inhibitor deficiencies. Blood. 1997; 89: 3213-8.

40. Nilsson T, Back O. Elevated plasmin-alpha 2-antiplasmin complex levels in hereditary angioedema: evidence for the in vivo efficiency of the intrinsic fibrinolytic system. Thromb Res. 1985; 40: 817-21.

41. Nielsen EW, Johansen HT, Hogasen K, Wuillemin W, Hack CE, Mollnes TE. Activation of the complement, coagulation, fibrinolytic and kallikrein-kinin systems during attacks of hereditary angioedema. Scand J Immunol. 1996; 44: 185-92.

42. van Geffen M, Cugno M, Lap P, Loof A, Cicardi M, van Heerde W. Alterations of coagulation and fibrinolysis in patients with angioedema due to $\mathrm{C} 1$-inhibitor deficiency. Clin Exp Immunol. 2012; 167: 472-8.

43. Schreiber AD, Kaplan AP, Austen KF. Inhibition by C1INH of Hagemann factor fragment activation of coagulation, fibrinolysis, and kinin generation. $J$ Clin Invest. 1973; 52: 1402-9.

44. Harpel PC, Cooper NR. Studies on human plasma C1 inactivator-enzyme interactions. I. Mechanisms of interaction with $\mathrm{C} 1 \mathrm{~s}$, plasmin, and trypsin. J Clin Invest. 1975; 55: 593-604.

45. Schousboe I. Pharmacological regulation of factor XII activation may be a new target to control pathological coagulation. Biochemical pharmacology. 2008; 75: 1007-13.

46. Gailani D, Renne T. The intrinsic pathway of coagulation: a target for treating thromboembolic disease? J Thromb Haemost. 2007; 5: 1106-12.

47. Chen JW, Figueiredo JL, Wojtkiewicz GR, Siegel C, Iwamoto Y, Kim DE, Nolte MW, Dickneite G, Weissleder R, Nahrendorf M. Selective factor XIla inhibition attenuates silent brain ischemia: application of molecular imaging targeting coagulation pathway. JACC Cardiovascular imaging. 2012; 5: 1127-38.

48. Hagedorn I, Schmidbauer S, Pleines I, Kleinschnitz C, Kronthaler U, Stoll G, Dickneite G, Nieswandt B. Factor XIla inhibitor recombinant human albumin Infestin-4 abolishes occlusive arterial thrombus formation without affecting bleeding. Circulation. 2010; 121: 1510-7.

49. Decrem Y, Rath G, Blasioli V, Cauchie P, Robert S, Beaufays J, Frere JM, Feron O, Dogne JM, Dessy C, Vanhamme L, Godfroid E. Ir-CPI, a coagulation contact phase inhibitor from the tick Ixodes ricinus, inhibits thrombus formation without impairing hemostasis. J Exp Med. 2009; 206: 2381-95.

50. Meltzer ME, Doggen CJ, de Groot PG, Rosendaal FR, Lisman T. The impact of the fibrinolytic system on the risk of venous and arterial thrombosis. Semin Thromb Hemost. 2009; 35: 468-77. 



\section{Summary}

\section{Samenvatting}

\section{Dankwoord}

\section{Publications}

\section{Curriculum Vitae}





\section{Summary}

Chapter 1 introduces the subject of this thesis. The structure of fibrin clots and their susceptibility to fibrinolysis are important determinants of the thrombotic risk. Clots characterized by a dense fibrin network and resistance to fibrinolysis are associated with an increased risk of thrombosis. The contribution of coagulation factor XII (FXII) to arterial thrombosis is less straightforward. Results from clinical studies are ambiguous, low levels of FXII and high levels of activated FXII (FXIla) are associated with arterial thrombosis, however not in all clinical studies. FXIla is able to initiate the intrinsic pathway of coagulation and thereby contributes to thrombin formation. Furthermore, FXIla can convert plasminogen into plasmin and thereby stimulate fibrinolysis.

The aim of the work described in this thesis, was to determine how FXII influences the fibrin clot structure and the susceptibility to fibrinolysis.

In chapter 2 the influence of FXIla on fibrin clot formation and structure was determined. In plasma and purified systems, we observed a dose-dependent increase in fibrin fiber density, and a non-linear increase in clot stiffness in the presence of $\alpha$-FXIla. In plasma, this increase was dependent on two mechanisms: 1) formation of thrombin via activation of the intrinsic pathway of coagulation, and 2) direct interaction of FXIla with fibrin(ogen). In binding experiments we showed that purified FXII and $\alpha-F X I l a$, but not $\beta$-FXIla, bound to purified fibrinogen and fibrin with nanomolar affinity. Furthermore, when we immunoprecipitated FXII from plasma, fibrinogen was present in the precipitate indicating co-precipitated of fibrinogen with FXII. Immunostaining of human carotid artery thrombi showed that FXII(a) co-localized with areas of dense fibrin(ogen) deposition. From these results, we concluded that FXlla modulates the fibrin structure via activation of the intrinsic pathway of coagulation and via direct interaction with fibrin(ogen).

An increase in density and rigidity of the fibrin clot (as we observed in the presence of $\alpha-\mathrm{FXIla}$ ) is characteristic for fibrin clots which are more difficult to lyse. However, $\alpha$-FXlla itself can also initiate fibrinolysis by converting plasminogen into plasmin. In chapter 3 we studied the contribution of $\alpha$-FXIla to clot stability and fibrinolysis in the presence of low levels of tissue plasminogen activator (tPA). We observed that $\alpha-F X$ Ila directly converted plasminogen into plasmin and reduced clot lysis time in the presence of tPA. This reduction in clot lysis time was caused by an earlier onset of plasmin formation due to the conversion of plasminogen into plasmin by $\alpha-\mathrm{FXIla}$. 


\section{Summary}

The main side effect of anticoagulant drugs used in current clinical practice is an increased risk of bleeding. Due to the fact that $\mathrm{FXII}^{-/-}$mice are protected from experimentally induced thrombosis, targeting FXIla to prevent thrombosis has been considered as a safe alternative. In chapter 4 , we tested a monoclonal antibody against FXIla for its effect on clot formation and fibrinolysis. We observed that the monoclonal antibody increased the clotting time dosedependently, when coagulation was initiated with a trigger of FXII. Furthermore, the monoclonal antibody reduced the maximal clot firmness and increased the maximal absorbance, indicative of a clot with thicker fibers and a reduced density. The effects on fibrinolysis were minor. In the whole blood ROTEM experiments, the clot lysis time was increased, whereas in turbidity experiments in platelet poor plasma the clot lysis time was decreased in the presence of the monoclonal antibody.

Results from clinical studies investigating the contribution of the contact system to arterial thrombosis are conflicting. In chapter 5 we determined activation of the contact activation system in patients with a first acute myocardial infarction (AMI) during the acute event and 3 and 6 months after the AMI. The degree of contact activation was determined in plasma as the levels of activated factor XI (FXla), FXIla and kallikrein in complex with $\mathrm{C} 1$ esterase inhibitor (C1INH) and the levels of FXla in complex with $\alpha_{1}$-antitrypsin (AT). The levels of FXla-C1INH were elevated during the acute event compared to the steady-phase 3 and 6 months after the AMI. The levels of FXIa-AT, FXIla-C1INH and kallikrein-C1INH did not change over time. Since the levels of FXIla-C1INH were not elevated, activation of $\mathrm{FXI}$ during the acute phase did probably not result from contact activation. The levels of FXla-C1INH, FXla-AT, FXIla-C1INH and kallikrein$\mathrm{C} 1 \mathrm{INH}$ were not predictive for a recurrent event.

Patients with arterial thrombosis often form fibrin clots with a dense structure, which are less susceptible to fibrinolysis compared to healthy individuals. Coronary stent thrombosis (ST) is a complication of percutaneous coronary intervention (PCl). In chapter 6 we determined if in ST patients the fibrin clot structure and fibrinolysis were altered compared to control $\mathrm{PCl}$ patients (patients that received a stent but did not develop ST). Fibrin clot formation and fibrinolysis were assessed by turbidimetric assays. In this study, there was no significant difference in lag time, maximal absorbance or clot lysis time between ST patients and control PCl patients.

Patients with hereditary angioedema due to a deficiency in C1INH (HAE$\mathrm{C} 1 \mathrm{INH})$ have impaired inhibition of the contact activation system. This leads to 
activation of the contact system and release of bradykinin (which mediates the symptoms observed in HAE-C1INH patients). However, these patients do not have an increased risk of thrombosis. We investigated whether activation of the contact system in these patients mainly leads to prekallikrein activation and less to $\mathrm{FXI}$ activation. In chapter 7 , we measured the activation of the contact system in patients with $\mathrm{HAE}-\mathrm{C} 1 \mathrm{INH}$. We did not observe an increase in the levels of enzyme inhibitory complexes between healthy controls, HAE-C1INH patients during remission or HAE-C1INH patients during an acute attack. When we activated the plasma samples with ellagic acid or dextran sulphate to activate FXII, the levels of FXIla-C1INH, FXIa-C1INH and kallikrein-C1INH were lower in patients compared to healthy controls. Addition of $\mathrm{C} 1 \mathrm{INH}$ to plasma of HAE-C1INH patients after activation led to an increase in FXIla-C1INH and FXla-C1INH levels. These results indicate consumption of both prekallikrein and $\mathrm{FXI}$, therefore the absence of increased thrombosis in these patients is probably due to the control of the coagulation system by other inhibitors, such as AT, and increased fibrinolysis.

In chapter 9 the main findings of this thesis are discussed. We have found that FXII has a dual role in coagulation and fibrinolysis. During clot formation, activation of FXII leads to a stronger fibrin clot, whereas during fibrinolysis, activation of FXII leads to the formation of plasmin and a faster onset of fibrinolysis. We postulate that during clot formation, FXIla stabilizes the thrombus by activating the intrinsic pathway of coagulation and by interaction with the fibrin network. This action prevents embolization. During fibrinolysis, FXIla helps to initiate plasmin formation at low levels of tPA and thereby prevents vessel occlusion.

Furthermore, we discussed the possibility using FXIla-inhibitors to prevent thrombosis. Although this seems a safe option, clinical trials are needed to determine which patients would benefit from FXIla inhibition. 



\section{Samenvatting}

In hoofdstuk 1 wordt het onderwerp van dit proefschrift geïntroduceerd. De structuur van fibrine stolsels en de gevoeligheid van deze stolsels voor fibrinolyse zijn belangrijke determinanten van het trombotisch risico. Stolsels die gekarakteriseerd worden door een hecht fibrine netwerk en een verhoogde resistentie tegen fibrinolyse zijn geassocieerd met een verhoogd risico op trombose. De bijdrage van stollingsfactor XII (FXII) aan arteriële trombose is minder duidelijk. De resultaten van klinische studies zijn tegenstrijdig. Lage concentraties FXII en hoge concentraties geactiveerd FXII (FXIla) zijn geassocieerd met arteriële trombose, hoewel niet in alle klinische studies. FXIla is in staat om de intrinsieke stollingscascade te initiëren en draagt zo bij aan trombine vorming. Daarnaast is FXIla in staat om plasminogeen naar plasmine om te zetten en stimuleert hiermee de fibrinolyse.

Het doel van het werk beschreven in dit proefschrift was te bepalen hoe FXII de structuur van het fibrine stolsel en de gevoeligheid voor fibrinolyse beïnvloedt.

In hoofdstuk 2 is de invloed van FXIla op de vorming en de structuur van fibrine stolsels bepaald. In aanwezigheid van a-FXlla, hebben we een dosisafhankelijke toename in de dichtheid van het fibrine netwerk en een niet-lineaire toename in de stijfheid van het stolsel waargenomen. In plasma, droegen twee processen bij aan deze toename: 1) de vorming van trombine via activatie van de intrinsieke stollingscascade, en 2) directe interactie van FXlla met fibrine en fibrinogeen. In bindingsexperimenten hebben we aangetoond dat gezuiverd FXII en $\alpha$-FXIla, maar niet $\beta$-FXIla, binden aan fibrinogeen en fibrine met een hoge affiniteit. Wanneer FXII werd immunogeprecipiteerd uit plasma, was fibrinogeen aanwezig in het precipitaat. Dit wijst erop dat fibrinogeen coprecipiteerde met FXII. Immunokleuring van humane trombi uit de halsslagader toonde co-lokalisatie aan van FXII en gebieden met compacte fibrine deposities. Aan de hand van deze resultaten concludeerden wij dat FXIla de fibrine structuur beïnvloedt via activatie van de intrinsieke stollingscascade en via directe interactie met fibrinogeen en fibrine.

Een toename in de dichtheid en rigiditeit van fibrine stolsels (zoals we hebben waargenomen in de aanwezigheid van $\alpha-\mathrm{FXIla)}$ is karakteristiek voor fibrine stolsels die moeilijker te lyseren zijn. Echter, $\alpha-F X I l a$ is in staat om de fibrinolyse te initiëren door plasminogeen om te zetten naar plasmine. In hoofdstuk 3 hebben we de bijdrage van a-FXIla aan de stabiliteit en fibrinolyse van stolsels onderzocht in de aanwezigheid van geringe hoeveelheden weefsel plasminogeen activator (tPA). We hebben waargenomen dat $\alpha$-FXIla 
plasminogeen naar plasmine kan omzetten en de tijd die nodig is om fibrine stolsels te lyseren (clot lysis time) reduceert in de aanwezigheid van tPA. Deze reductie in clot lysis time werd veroorzaakt door een eerdere vorming van plasmine uit plasminogeen door $\alpha-F X I l a$.

De huidige antistollingsmiddelen hebben als voornaamste bijwerking dat ze het risico op bloedingen verhogen. Sinds de observatie dat $\mathrm{FXII}^{-1-}$ muizen beschermd zijn tegen experimenteel geïnduceerde trombose, wordt het remmen van FXIla als middel om trombose te voorkomen beschouwd als een veilig alternatief voor de huidige medicatie. In hoofdstuk 4 hebben wij het effect van een monoclonaal antilichaam gericht tegen FXIla op de vorming en afbraak van stolsels getest. Uit onze experimenten blijkt dat het monoclonaal antilichaam de stollingstijd dosis-afhankelijk verhoogde wanneer stolling geïnitieerd werd met een FXII activator. Daarnaast verlaagde het monoclonaal antilichaam de stevigheid van het stolsel en verhoogde het de maximale absorptie. Dit wijst op een stolsel met dikkere fibrine draden en een lagere dichtheid. De effecten op de fibrinolyse waren klein. De clot lysis time was verlengd in de experimenten uitgevoerd met de volbloed ROTEM, maar verkort in de turbiditeitsexperimenten in plaatjes arm plasma in de aanwezigheid van het antilichaam.

Verschillende klinische studies hebben de bijdrage van het contact systeem aan arteriële trombose onderzocht, echter de resultaten van deze studies zijn niet eenduidig. In hoofdstuk 5 hebben we de mate van activatie van het contact systeem gemeten bij patiënten die een eerste acuut myocard infarct (AMI) doormaakten. De bloedmonsters voor analyse werden afgenomen tijdens het acute infarct en na 3 maanden en 6 maanden. Om de mate van activatie van het contact systeem te bepalen, werden de bloedwaarden van geactiveerd factor XI (FXla), FXIla en kallikreïne in complex met C1-esterase inhibitor $(\mathrm{C} 1 \mathrm{INH})$ en de waarden van FXla in complex met $\alpha_{1}$-antitrypsine (AT) gemeten. De bloedwaarden van FXla-C1INH waren verhoogd tijdens het acute infarct vergeleken met de waarden 3 en 6 maanden na het infarct. De waarden van FXla-AT, FXIla-C1INH en kallikreïne-C1INH veranderden niet in de tijd. Aangezien de waarden van FXIla-C1INH niet verhoogd waren, werd de activatie van FXI tijdens het acute infarct waarschijnlijk niet veroorzaakt door activatie van het contact systeem. De waarden van FXla-C1INH, FXla-AT, FXIla-C1INH en kallikreïne-C1INH waren niet voorspellend voor het krijgen van een tweede hart- en vaataandoening. 
Patiënten met arteriële trombose vormen vaak een fibrine stolsel met een hechte structuur, dat minder gevoelig is voor fibrinolyse dan stolsels van gezonde individuen. Coronaire stent trombose (ST) is een complicatie die kan optreden na een percutane coronaire interventie (PCI). In hoofdstuk 6 hebben we onderzocht of de structuur en afbraak van fibrine stolsels in patiënten met ST afweek van stolsels van controle $\mathrm{PCl}$ patiënten (dit waren patiënten bij wie een stent geplaatst was, zonder dat ze ST ontwikkelden). Fibrine vorming en fibrinolyse werden bepaald door middel van turbidimetrische metingen. In deze studie was er geen significant verschil in de tijd tot de vorming van een fibrine stolsel, de maximale absorptie en de clot lysis time tussen ST patiënten en controle $\mathrm{PCl}$ patiënten.

De remming van het contact systeem is aangedaan bij patiënten met hereditair angio-oedeem door een deficiëntie in C1INH (HAE-C1INH). Dit leidt tot activatie van het contact systeem en het vrijkomen van bradykinine (wat de symptomen veroorzaakt bij HAE-C1INH patiënten). Echter, deze patiënten hebben geen verhoogd risico op trombose. Wij hebben onderzocht of de activatie van het contact systeem bij HAE-C1INH patiënten met name leidt tot activatie van prekallikreïne en minder tot activatie van FXI. In hoofdstuk 7 hebben we de activatie van het contact systeem gemeten in patiënten met HAE-C1INH en gezonde individuen. Er was geen meetbaar verschil in contact activatie tussen gezonde individuen, HAE-C1INH patiënten tijdens remissie en HAE-C1INH patiënten tijdens een acute aanval van angio-oedeem. Wanneer we echter het plasma behandelden met ellagine zuur of dextraan sulfaat om FXII te activeren, waren de concentraties FXIla-C1INH, FXla-C1INH en kallikreïne-C1INH lager in patiënten vergeleken met gezonde individuen. Toevoeging van $\mathrm{C} 1 \mathrm{INH}$ aan plasma van patiënten met HAE-C1INH na activatie van dit plasma leidde tot een toename in de waarden van FXIla-C1INH en FXla-C1INH. Deze resultaten duidden op verbruik van zowel prekallikreïne als $\mathrm{FXI}$, er was dus geen voorkeur voor de activatie van prekallikreïne. De afwezigheid van een verhoogd risico op trombose bij patiënten met HAE-C1INH is waarschijnlijk het gevolg van een goede regulatie van de bloedstolling door andere natuurlijke stollingsremmers, zoals AT, en een verhoogde fibrinolyse.

In hoofdstuk 9 worden de voornaamste bevindingen van dit proefschrift besproken. We hebben gevonden dat FXII een dubbele rol speelt in bloedstolling en fibrinolyse. Tijdens stolsel vorming, leidt activatie van FXII tot een sterker fibrine stolsel, terwijl tijdens de fibrinolyse, activatie van FXII leidt tot de vorming van plasmine en een snellere start van de fibrinolyse. Wij veronderstellen dat tijdens stolselvorming, FXIla de trombus stabiliseert door 
activatie van de intrinsieke stollingscascade en door interactie met het fibrine netwerk. Hiermee wordt embolizatie van de trombus voorkomen. Tijdens de fibrinolyse, helpt FXIla bij de initiatie van plasmine vorming bij lage tPA concentraties en voorkomt hiermee de occlusie van bloedvaten.

Daarnaast hebben we de mogelijkheid besproken om remmers van FXIla te gebruiken ter preventie van trombose. Hoewel dit een veilige optie lijkt, zijn klinische trials nodig om te bepalen welke patiënten baat hebben bij farmacologische remming van FXIla. 


\section{Dankwoord}

Het voltooien van dit proefschrift betekent vanzelfsprekend ook het einde van het promotietraject. Een traject waarbij ik veel mensen heb leren kennen - zowel zakelijk als privé - die ik bij deze speciaal wil bedanken voor deze leuke, uitdagende en zeer leerzame periode.

Prof. dr. ten Cate, beste Hugo, toen ik vijf jaar geleden op sollicitatiegesprek kwam wist ik maar weinig over de bloedstolling. Na ons gesprek wist ik echter zeker dat ik hier graag onderzoek in zou willen doen en kon ik niet wachten om met jou en José aan het werk te gaan. Ondanks je drukke schema was je altijd erg betrokken bij ons onderzoek. Deze betrokkenheid heeft me op de juiste momenten gemotiveerd om het onderzoek op een leuke, leerzame manier aan te pakken. Met problemen kon ik altijd bij je terecht. Bedankt voor het vertrouwen en alle discussies die hebben bijgedragen aan het voltooien van dit proefschrift.

Dr. Govers-Riemslag, beste José, jij hebt me de weg gewezen in de wereld van het onderzoek en de bloedstolling. Ik waardeer je enthousiasme voor onderzoek enorm! Je had altijd vertrouwen in ons onderzoek en dat heeft me zeker geholpen als ik het even niet meer zag zitten. Ik denk dat er maar weinig aio's zijn die met veel plezier zoveel tijd samen met hun co-promotor op het lab hebben doorgebracht. Ook daarbuiten hebben we samen veel leuke dingen gedaan. Ik wil je van harte bedanken voor alle kennis die je me hebt bijgebracht en de kansen die jij en Hugo me hebben gegeven. Door jullie verschillende achtergrond (klinisch respectievelijk basaal wetenschapper) heb ik het beste meegekregen van beide werelden.

Leden van de beoordelingscommissie: prof. dr. C.D. Stehouwer, prof. dr. T.M. Hackeng, prof. dr. M. Levi, dr. M.P. de Maat en prof. dr. R.J. van Oostenbrugge, hartelijk dank voor het beoordelen van mijn proefschrift. Beste Tilman, naast je bijdrage als lid van de beoordelingscommissie ook een speciale dank voor je vakgroep voorzitterschap.

Dear Robert and Helen, I would like to thank you for the opportunity to work in your laboratory in Leeds and for all our discussions on site and online. I think I only now realize that Skype is one of the best inventions ever. Your contribution to my thesis was invaluable. Special thanks to everyone that helped me in Leeds, and especially Nicola, Emma, Peter, Sumitra and Lewis for your contribution to my thesis. 
Kamergenoten, zonder jullie was mijn promotietijd nooit zo leuk geweest. Bedankt voor de gezelligheid en alle zinnige en onzinnige gesprekken, zowel op het werk als daarbuiten. Dear Evren, I enjoyed being your room mate and your friend. I'm sure we'll meet again, in Turkey or The Netherlands. Annemieke, ik vind het super dat je op 24 januari aan mijn zijde wil staan als paranimf na twee jaar samen gewerkt te hebben op één kamer! Geert-Jan, naast dat je een fantastische kamergenoot was, hebben we ook regelmatig gezellige avonden gehad met en zonder het Biochemie-quiz-team: Frauke, Marie-Claire, Rinske, Dennis, Martijn, en Brecht. Allemaal heel erg bedankt voor de gezellige avonden. Pieter, de dagen dat je er was, waren altijd heel erg leuk! Ik weet zeker dat ook jouw proefschrift ooit af zal raken. We moeten snel weer met zijn allen gaan eten!

Graag wil ik ook mijn overige collega's van het lab klinische trombose en hemostase bedanken: Henri, René, Arina, Karly, Sarah, Paola, Julian, Kristien, Patricia, Diane, Marieke, Petra, Yvonne, Rick en Paul. Bedankt voor jullie kritische blik op mijn resultaten tijdens de werkbesprekingen, maar ook voor de niet-werkgerelateerde praatjes en gezelligheid tijdens lab-uitjes en congressen. Een speciaal bedankje voor Lisa, Kim en Hellal voor de extra hulp op het lab.

Tijdens het laatste jaar van mijn promotie hebben José en ik samenwerking met Synapse BV gezocht en dankzij hun bijdrage kon ik mijn proefschrift afmaken. Beste Bas, bedankt voor het in mij gestelde vertrouwen en de ondersteuning van mijn onderzoek. Daarnaast natuurlijk ook bedankt voor de fantastische kans die jullie me gegeven hebben om bij Synapse aan de slag te gaan als post doc. Ook wil ik al mijn nieuwe collega's bedanken en in het bijzonder Marisa voor je hulp bij mijn hoofdstuk over fibrinolyse.

ledereen van de afdeling Biochemie wil ik ook graag bedanken! Meer in het bijzonder Guido, voor al je hulp tijdens de eerste jaren van mijn promotie en Trees, voor je hulp bij al het papierwerk.

I would like to thank all other contributors to my thesis: Thea, dr. J.M. ten Berg, dr. C.M. Hackeng, prof. dr. M. Cicardi, dr. M. Cugno, ms. C. Suffriti and prof. dr. J.L. Waltenberger. It was an honor to collaborate with you.

Lieve vrienden en (schoon)familie bedankt voor jullie steun, betrokkenheid en interesse de afgelopen jaren. In het bijzonder Carola. Je bent al 16 jaar mijn beste vriendin. We hebben dezelfde interesses en humor, je hebt me al vaak gesteund en ik ben dan ook erg blij dat je 24 januari naast me zult staan. 
Lieve papa, ik had me geen betere vader kunnen wensen. Ik weet zeker dat je trots op me bent en er graag bij was geweest. Lieve Bart, bedankt dat je mijn grote broer was. Ik mis jullie nog iedere dag. Lieve mama en Anne, we zijn vaak op de proef gesteld, maar ondanks alle tegenslagen zijn we een hecht gezin. Jullie staan dag en nacht voor mij klaar. Bedankt voor jullie warmte en steun.

Lieve Maarten, ik wil je bedanken voor al je hulp om mijn proefschrift op tijd af te krijgen, maar vooral voor ons leven buiten het werk. Samen met jou is het leven een stuk leuker! 



\section{Publications}

\section{Papers}

Konings J, Cugno M, Suffritti C, Ten Cate H, Cicardi M, Govers-Riemslag JW. Ongoing contact activation in patients with hereditary angioedema. PloS one. 2013; 8: e74043.

Konings J, Govers-Riemslag JW, Spronk HM, Waltenberger JL, Ten Cate H. Activation of the contact system in patients with a first acute myocardial infarction. Thrombosis research. 2013; 132: 138-42.

Konings J, Govers-Riemslag JW, Philippou H, Mutch NJ, Borissoff JI, Allan P, Mohan S, Tans G, Ten Cate H, Ariens RA. Factor Xlla regulates the structure of the fibrin clot independently of thrombin generation through direct interaction with fibrin. Blood. 2011; 118: 3942-51.

Scheepers PT, Bos PM, Konings J, Janssen NA, Grievink L. Application of biological monitoring for exposure assessment following chemical incidents: a procedure for decision making. Journal of exposure science \& environmental epidemiology. 2011; 21: 247-61.

Scheepers PT, Konings J, Demirel G, Gaga EO, Anzion R, Peer PG, Dogeroglu $T$, Ornektekin $S$, van Doorn W. Determination of exposure to benzene, toluene and xylenes in Turkish primary school children by analysis of breath and by environmental passive sampling. The Science of the total environment. 2010; 408: 4863-70.

de Jonge JD, Pennings JL, Baken KA, Konings J, Ezendam J, Van Loveren H. Gene expression changes in the mesenteric lymph nodes of rats after oral peanut extract exposure. Journal of immunotoxicology. 2008; 5: 385-94.

\section{Book chapter}

Konings J, Govers-Riemslag JWP, Ten Cate $\mathrm{H}$. Novel insights into genetics of arterial thrombosis. In: Clinical cardiogenetics. Springer Verlag London. 2011; p $333-54$. 


\section{Publications}

\section{$\underline{\text { Abstracts }}$}

\section{Oral presentations}

Konings J, Hoving L, Ariëns RAS, Smith E, Ninivaggi M, Hardy L, de Laat B, ten Cate H, Philippou H, Govers-Riemslag JWP. FXIla enhances fibrinolysis in addition to plasminogen activators. XXIV Congress of the International Society on Thrombosis and Haemostasis (ISTH), Amsterdam, The Netherlands, 2013

Konings J, Govers-Riemslag JWP, Philippou H, Ariëns RAS, Ten Cate H. On the opposing effects of factor Xlla on clot stability. Fibrinogen Workshop, Brighton, UK, 2012

Konings J, Govers-Riemslag JWP, Philippou H, Mutch NJ, Borissoff JI, Mohan $S$, Tans $G$, Ten Cate $H$, Ariëns RAS. Coagulation factor XIla influences human fibrin clot structure independent of additional thrombin generation. XXIII Congress of the International Society on Thrombosis and Haemostasis (ISTH), Kyoto, Japan, 2011

Konings J, Govers-Riemslag JWP, Philippou H, Mutch NJ, Tans G, Ariëns RAS, Ten Cate $\mathrm{H}$. Coagulation factor $\mathrm{XII}$ influences fibrin clot structure. Symposium Nederlandse Vereniging voor Trombose en Hemostase (NVTH), Noordwijkerhout, The Netherlands, 2010

\section{Posters}

Konings J, Cugno M, Suffritti C, ten Cate H, Cicardi M, Govers-Riemslag JWP. Ongoing contact activation in patients with hereditary angioedema. XXIV Congress of the International Society on Thrombosis and Haemostasis (ISTH), Amsterdam, The Netherlands, 2013

Godschalk TC, Konings J, Govers-Riemslag JW, ten Berg JM, Hackeng CM, ten Cate $\mathrm{H}$. Fibrin clot formation and fibrinolysis in patients with coronary stent thrombosis. XXIV Congress of the International Society on Thrombosis and Haemostasis (ISTH), Amsterdam, The Netherlands, 2013

Konings J, Govers-Riemslag JWP, Philippou H, Ariëns RAS, Ten Cate H. The interface between the contact activation system of coagulation and the fibrinolytic system. Gordon Research Conference (GRC) \& Gordon Research 
Seminar (GRS) on Plasminogen Activation and Extracellular Proteolysis, Ventura, USA, 2012

Konings J, Govers-Riemslag JWP, Philippou H, Mutch NJ, Tans G, Ariëns RAS, Ten Cate $\mathrm{H}$. The impact of coagulation factor XII on clot structure and resistance to lysis. Congress of the International Society for Fibrinolysis and Proteolysis (ISFP), Amsterdam, The Netherlands, 2010

Konings J, Govers-Riemslag JWP, Philippou H, Mutch NJ, Tans G, Ariëns RAS, Ten Cate $\mathrm{H}$. The impact of coagulation factor XII on clot structure and resistance to lysis. Fibrinogen Workshop, Rotterdam, The Netherlands, 2010

Pönitz V, Govers-Riemslag JWP, Konings J, Brügger-Andersen T, Grundt H, Ten Cate $\mathrm{H}$, Staines $\mathrm{H}$, Nilsen DWT. The plasma kallikrein-kinin system and clinical outcome during follow-up in chest-pain patients. XXII Congress of the International Society on Thrombosis and Haemostasis (ISTH), Boston, USA, 2009.

\section{Awards}

Beste publicatie promovendus. Dag Interne Geneeskunde azM 2011, Maastricht, Nederland

Young investigator award. XXIII Congress of The International Society on Thrombosis and Haemostasis (ISTH) 2011, Kyoto, Japan

Wetenschapsprijs. Symposium van de Nederlandse Vereniging voor Trombose en Hemostase (NVTH) 2010, Noordwijkerhout, Nederland 



\section{Curriculum Vitae}

Joke Konings was born on April $14^{\text {th }}, 1985$ in Nieuwegein, The Netherlands. She completed her secondary education (gymnasium) at the Valuascollege in Venlo (The Netherlands) in 2003. After that, she started to study Biomedical Sciences at the Radboud University in Nijmegen (The Netherlands). In 2008 she obtained her master's degree with honor, majoring in "Toxicology" and "Occupational and Environmental Health". In the same year she started to work as a research scientist at the Radboud University at the Department of Epidemiology, Biostatistics and HTA, followed by a PhD position at the department of Biochemistry and Internal Medicine at Maastricht University in January 2009. Her main research topic was the influence of coagulation factor XII on arterial thrombosis, funded by the Netherlands Heart Foundation and resulting in this thesis. As PhD student she was under supervision of prof. dr. $\mathrm{H}$. ten Cate and dr. J.W.P. Govers-Riemslag. In 2013 Synapse BV started to fund the research and Joke obtained a position as post doc in this company. 